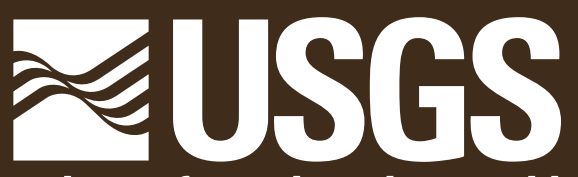

science for a changing world

\title{
Stratigraphy, Lithology, and Sedimentary Features of Quaternary Alluvial Deposits of the South Platte River and Some of its Tributaries East of the Front Range, Colorado
}

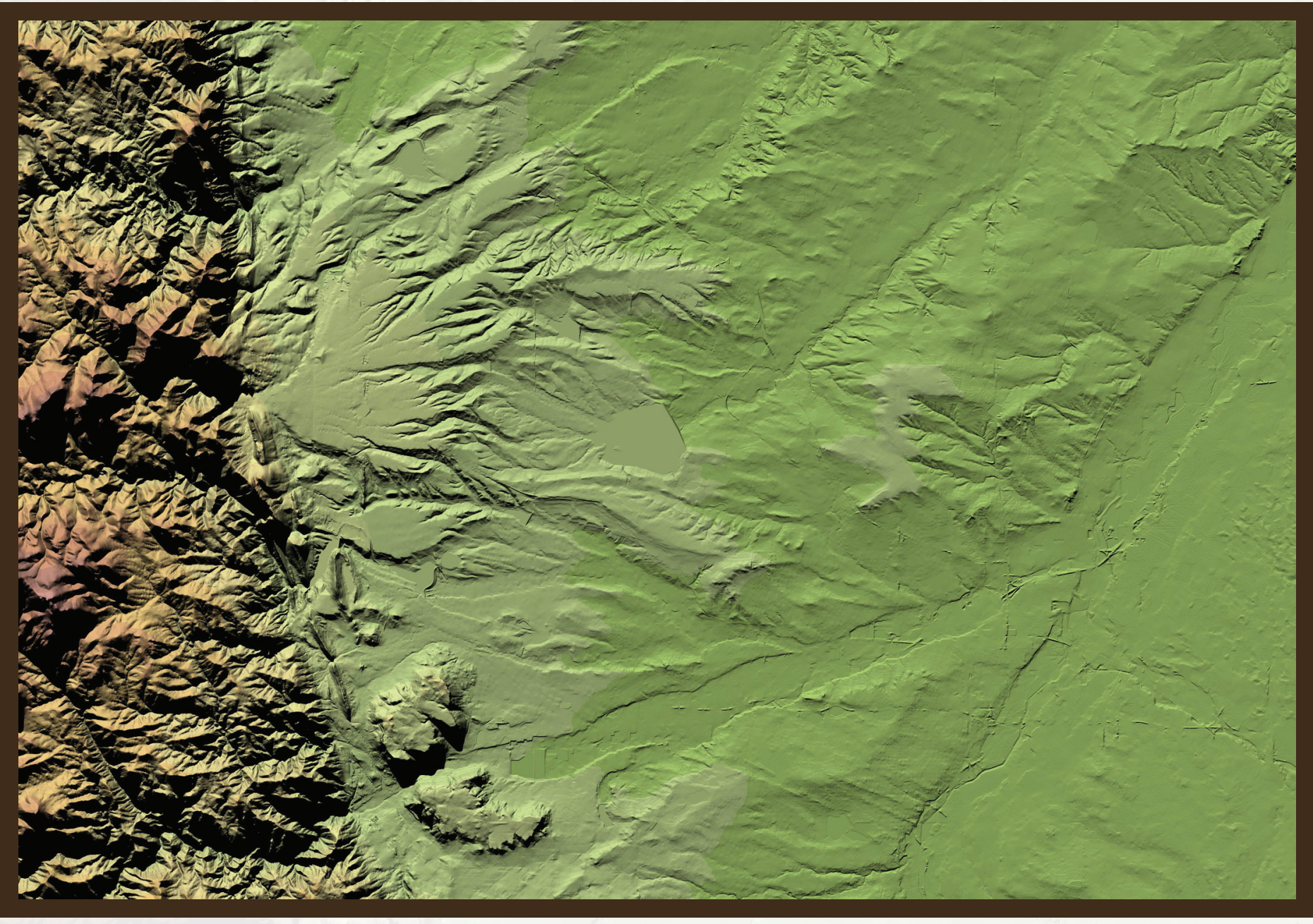

Professional Paper 1705 
Cover. Digital elevation model showing terraces of Clear Creek and the South Platte River and the dissected alluvial fan of Rocky Flats. Courtesy of C.S. Mladinich. 


\section{Stratigraphy, Lithology, and Sedimentary Features of Quaternary Alluvial Deposits of the South Platte River and Some of its Tributaries East of the Front Range, Colorado}

By David A. Lindsey, William H. Langer, and Daniel H. Knepper, Jr.

Professional Paper 1705 


\section{U.S. Department of the Interior \\ Gale A. Norton, Secretary \\ U.S. Geological Survey \\ P. Patrick Leahy, Acting Director}

U.S. Geological Survey, Reston, Virginia: 2005

For product and ordering information:

World Wide Web: http://www.usgs.gov/pubprod/

Telephone: 1-888-ASK-USGS

For more information on the USGS - the Federal source for science about the Earth, its natural and living resources, natural hazards, and the environment:

World Wide Web: http://www.usgs.gov/

Telephone: 1-888-ASK-USGS

Any use of trade, product, or firm names in this publication is for descriptive purposes only and does not imply endorsement by the U.S. Government.

Although this report is in the public domain, permission must be secured from the individual copyright owners to reproduce any copyrighted materials contained within this report.

Suggested citation:

Lindsey, D.A., Langer, W.H., and Knepper, D.H., Jr., 2005, Stratigraphy, lithology, and sedimentary features of Quaternary alluvial deposits of the South Platte River and some of its tributaries east of the Front Range, Colorado: U.S. Geological Survey Professional Paper 1705, 70 p. 


\section{Contents}

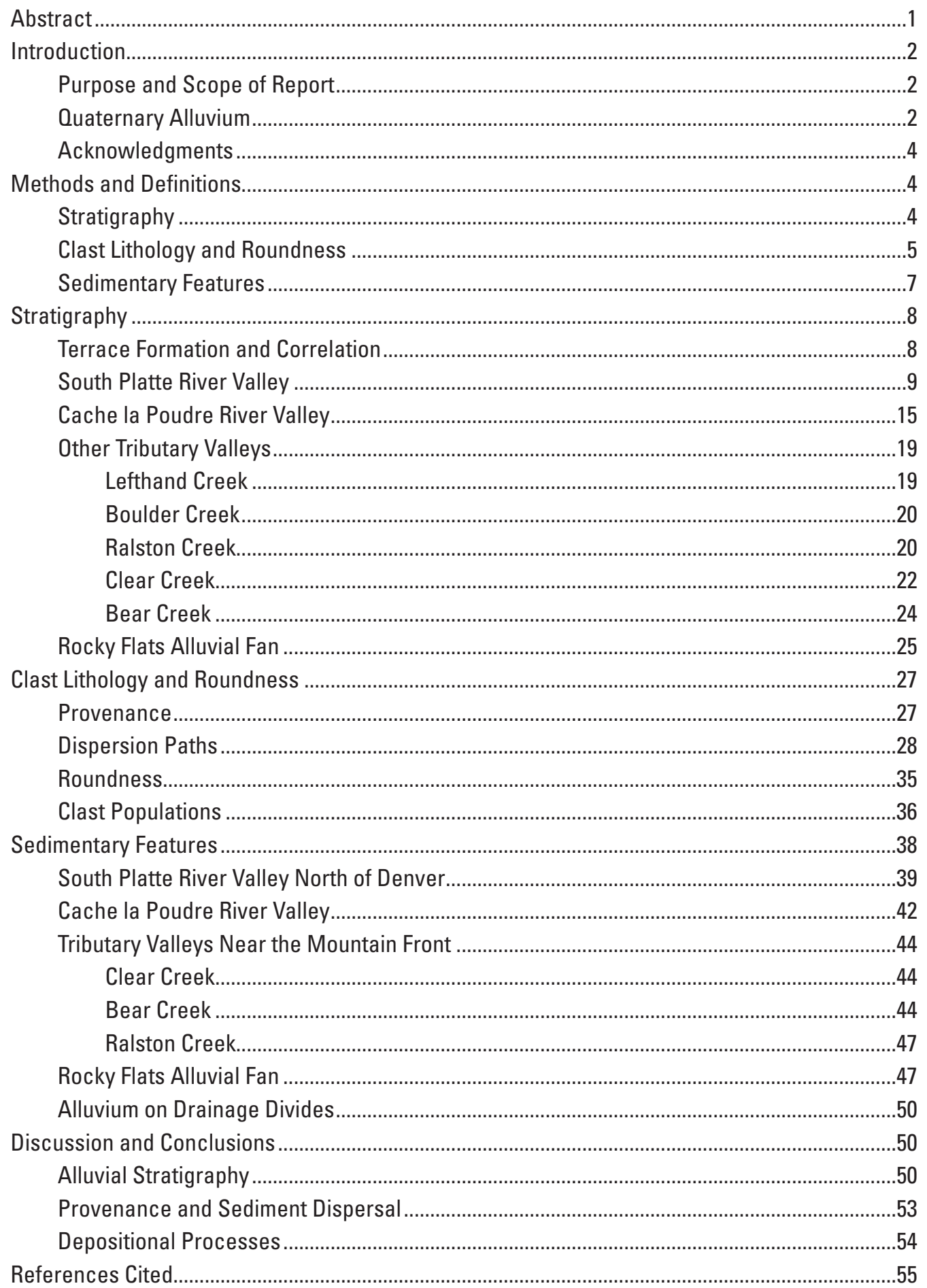


Appendix: Lithologic Control of Rounding in Different Clast Populations ........................................61

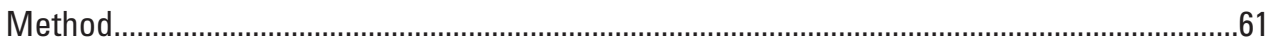

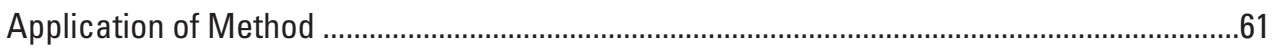

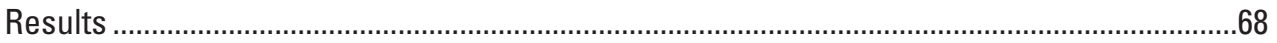

\section{Figures}

1. Block diagram showing alluvial surfaces of the South Platte River and its tributaries

2. Map showing location of sections through valley fill, South Platte River and tributaries

3. Map showing sources of data on lithology and rounding of gravel clasts and sedimentary features, South Platte River and tributaries.

4. Sections through alluvial fill of the South Platte River valley, Greeley to Denver ..........10

5. Histograms showing particle size in three gravel units, South Platte River valley........15

6. Sections through alluvial fill of the Cache la Poudre River valley from Fort Collins to Greeley.

7. Photograph showing differences in color, texture, and particle size between two gravel units beneath the flood plain of the Cache la Poudre River .........................18

8. Histograms showing particle size in gravel units, Cache la Poudre River valley ..........19

9. Sections through alluvial fill of the valleys of Lefthand and Boulder Creeks .................20

10. Sections through alluvial fill of the valley of Ralston Creek near the foothills ...............21

11. Aerial photograph showing paleochannel in Verdos Alluvium, Ralston Creek..............22

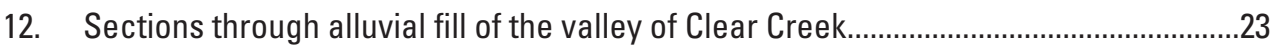

13. Sections through alluvial fill of the valley of Bear Creek ..................................................24

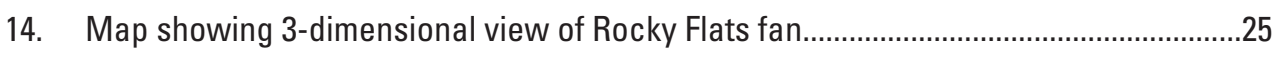

15. Map showing thickness of Rocky Flats Alluvium .....................................................26

16. Map showing topography of base of Rocky Flats Alluvium.............................................27

17. Map showing distribution of volcanic rocks and amphibolite + schist + diabase in alluvium, South Platte River and tributaries............................................................29

18. Map showing distribution of vein quartz and quartzite in gravel alluvium, South Platte River drainage basin.

19. Photographs of outcrop of bedded Precambrian metaquartzite in Coal Creek Canyon and metaquartzite clasts in gravel at Riley Mound

20. Transect showing pebble lithology from Rocky Flats to Beebe Draw ...........................35

21. Pebble roundness in alluvium of the South Platte drainage basin................................37

22. Sketches and photograph of pit walls at the Howe gravel pit, South Platte River, showing gravel units and sedimentary features

23. Photograph of gravel units and sedimentary features, North Dahlia pit, South Platte River valley...

24. Photographs of channel and bar features, North Dahlia gravel pit, South Platte River valley...

25. Photograph of sedimentary features in undivided gravel at the Taft Hill gravel pit, Cache la Poudre River valley.

26. Photographs of sedimentary features in lower and upper gravel units, Cache la Poudre River valley. 
27. Photographs of pit face in Louviers Alluvium, Clear Creek, showing sedimentary features

28. Photographs of Louviers Alluvium, Bear Creek valley, showing sedimentary features and boulder size.

29. Photographs of Verdos Alluvium, Ralston Creek valley, showing sedimentary features

30. Photographs of Rocky Flats Alluvium, Rocky Flats, showing sedimentary features .....49

31. Photographs of Rocky Flats Alluvium, Arvada, showing sedimentary features.............51

32. Simplified sections of late Pleistocene and Holocene terraces and fill, South Platte River, Cache la Poudre River, Clear Creek, and Bear Creek.......................52

A1. Poorly rounded quartzite gravel, Verdos Alluvium, Rocky Flats ....................................63

A2. Poorly rounded gravel, mostly gneiss, amphibolite, and quartzite, Verdos Alluvium, Ralston Creek

A3. Moderately rounded gravel, pegmatite and gneiss, some vein quartz, and volcanic rock, Slocum Alluvium, Bear Creek.

A4. Moderately rounded gravel with granite, pegmatite, gneiss, vein quartz, and quartzite, Verdos Alluvium, divide between South Platte River and Big Dry Creek

A5. Well-rounded gravel, mostly granite and gneiss, Louviers Alluvium, Clear Creek........67

A6. Well-rounded gravel, mostly gneiss, Holocene Alluvium (upper gravel unit), South Platte River

\section{Tables}

1. Pebble lithology and roundness in single samples of gravel, early Pleistocene to Holocene alluvium, South Platte River and tributaries

2. Pebble lithology and roundness in composite samples of gravel, Broadway(?) and Holocene alluvium of the South Platte River and tributaries

A1. Lithology versus roundness of pebbles in Rocky Flats and Verdos Alluvium, Rocky Flats and upper Big Dry Creek

A2. Lithology versus roundness of pebbles in Verdos and Piney Creek Alluvium, Ralston Creek......

A3. Lithology versus roundness of pebbles in Rocky Flats, Verdos, and

Slocum Alluvium derived from Green Mountain

A4. Lithology versus roundness of pebbles in Rocky Flats and Verdos Alluvium, divide between Big Dry Creek and South Platte River

A5. Lithology versus roundness of pebbles in Louviers and Broadway Alluvium, Clear Creek

A6. Lithology versus roundness of pebbles in Broadway(?) and Holocene Alluvium, South Platte River north of Denver

A7. Lithology versus roundness of pebbles in Broadway(?) and Holocene Alluvium, Cache la Poudre River.

A8. Summary of correlation of rounding with lithology, as predicted by chi-square tests 


\title{
Stratigraphy, Lithology, and Sedimentary Features of Quaternary Alluvial Deposits of the South Platte River and Some of its Tributaries East of the Front Range, Colorado
}

\author{
By David A. Lindsey, William H. Langer, and Daniel H. Knepper, Jr.
}

\section{Abstract}

The Quaternary alluvial deposits of the South Platte River and some of its mountain tributaries east of the Front Range were examined by reconstructing stratigraphic relationships, mapping pebble lithology, and describing sedimentary features. Borehole logs from previous investigations, used to construct sections, reveal the alluvial stratigraphy of terraces in the South Platte and Cache la Poudre River valleys and of tributary valleys from Lefthand Creek south to Bear Creek. For the type Rocky Flats Alluvium, maps of topography and thickness show the geometric form of the deposit. Maps of pebble lithology and roundness, compiled from previous studies and new data, show dispersal patterns in alluvium of varying age. Sedimentary features in selected gravel pits in the South Platte River valley north of Denver, in the Cache la Poudre River valley between Fort Collins and Greeley, and in alluvium deposited by tributary streams near the mountain front west of Denver, reveal details of depositional processes.

Terraces occupy stream valleys of all sizes east of the Front Range. Thin channel fills and gravel lags occur high on drainage divides and along small streams draining these divides. Although locally heterogeneous, many consist entirely of gravel. They represent periods of lateral cutting and brief periods of equilibrium when streams crossed the threshold between aggradation and degradation. The thickest terrace fills consist of Louviers and Broadway Alluvium along major streams. These deposits represent aggradation during increased sediment production, followed by incision when sediment production waned. Laterally extensive units of sand, silt, and clay, some of which may be eolian, occur within and on Broadway and Louviers terraces of the South Platte and Cache la Poudre Rivers. These deposits formed when streams left fine-grained sediment on flood plains during high discharge. When flood water subsided, the sediment dried, and winds swept it across the valley surface and onto adjacent uplands. Increased sediment production, terrace aggradation, and extensive deposition of fine-grained sediment on flood plains may be a response to glacier retreat in headwater valleys of major streams.
At the end of Pleistocene time, the South Platte River cut through Broadway Alluvium and into bedrock of the Denver Formation. Incision entrained alluvium and increased sediment production, leading to deposition downstream. The record of incision is seen in gravel pits and borehole logs from Fort Lupton to south of Denver, where coarse pebble and cobble gravel occurs at the base of the valley fill. The record of aggradation is found in the downstream half of this reach where sandy gravel conformably overlies the basal gravel. During Holocene time, the upper part of the gravel fill of some of the largest streams, including the South Platte River, the Cache la Poudre River, and St. Vrain Creek, was reworked by lateral cutting and filling as these streams reached near-equilibrium.

Not all alluvial deposits east of the Front Range are terrace fills and lags. The coarse gravel of the type early Pleistocene Rocky Flats Alluvium was probably deposited on an alluvial fan that drained into ancestral Big Dry Creek. The surface beneath the alluvium of Rocky Flats has a dissected appearance, complete with stream valleys and a resistant sandstone hogback of Upper Cretaceous Fox Hills Formation blocking and diverting drainage. In contrast, the top of the Rocky Flats Alluvium is a smooth, gently sloping, deeply weathered surface that is being dissected by headward erosion of modern streams. The Rocky Flats surface was probably abandoned when Coal Creek beheaded Big Dry Creek before deposition of early middle Pleistocene Verdos Alluvium. The accompanying decrease in discharge shrank ancestral Big Dry Creek to a small stream whose tributaries eventually began to cut headward into the Rocky Flats fan.

Most Quaternary gravel east of the Front Range consists of granite, gneiss, and pegmatite clasts. However, gray metamorphic quartzite derived from Coal Creek Canyon defines a large dispersion path that extends east-northeast across the present course of the South Platte River. The dispersion path of quartzite was a dominant feature of early Pleistocene time, when the Rocky Flats alluvial fan was being constructed. Minor quantities of volcanic clasts, Precambrian mafic rocks, and vein quartz also define dispersion paths from other sources. Where these paths join the quartzite path, the abundance of quartzite is much diluted by abundant granitic 
Stratigraphy, Lithology, and Sedimentary Features of Quaternary Alluvial Deposits, S. Platte River and Tributaries, Colo.

rocks and gneiss. Together, all of the dispersion paths define a generalized transport pattern that followed the present course of the South Platte River during early Pleistocene time. Later, during middle Pleistocene time, the South Platte cut a valley through Beebe Draw, located at the easternmost, distal end of the quartzite dispersion path. By late Pleistocene time, the South Platte had assumed its present course.

The degree of rounding of pebbles is useful in distinguishing gravel deposits of large streams with glaciated headwater valleys from those of small mountain streams. Gravel of Louviers, Broadway, and younger alluvium deposited by large streams with glaciated mountain headwaters is well rounded; gravel deposited by small streams is angular. Gravel in Slocum and older alluvium, some of it recycled from older gravel and conglomerate, varies from poorly rounded near sources such as the slopes of Green Mountain to moderately rounded downstream in terrace remnants on both sides of the South Platte River.

Two categories of gravel deposits are distinguished by assemblages of sedimentary features: (1) deposits formed by intermittent deposition and scouring and (2) deposits formed rapidly by flash floods. Deposits formed by intermittent deposition and scouring are composed of channel and bar deposits much like those seen in major streams east of the Front Range today. Sedimentary features include channel scours; channel and bar-top clast armors and imbricate clusters; bar sequences of apron, tabular foreset, and topset laminae; and sets of accretionary laminae bounded by reactivation surfaces. Where aggradation (vertical accretion) has been dominant, channel and bar deposits are stacked on one another. Where nearequilibrium conditions with lateral cutting and back-filling prevailed, channel and bar deposits are amalgamated laterally. Where degradation prevailed, only thin gravel lags and remnants of bar deposits in shallow channels remain.

Flash-flood deposits tend to form at the mountain front. As floodwaters emerge from steep canyons, they spread laterally and lose competency to transport coarse bedload. Wide range in clast size (including large boulders), poor clast rounding, and highly lenticular gravel lenses with small bartop features such as imbricate clusters with sand shadows are characteristic of flash-flood deposits. Flash-flood deposits have been identified in both large and small stream valleys; they include thin terrace fill of Louviers Alluvium along Bear Creek, and they comprise most of the Rocky Flats alluvial fan. Both are mountain-front settings.

\section{Introduction}

\section{Purpose and Scope of Report}

The South Platte and Arkansas Rivers have shaped much of the Colorado Piedmont landscape during late Tertiary and Quaternary time. North and east of Denver, the South Platte and its tributaries excavated valleys in the soft sedimentary rocks of the Denver Basin and, during brief pauses in excavation, allowed thin deposits of alluvium and eolian sediment to accumulate. Thin terrace, alluvial-fan, and eolian deposits are the only records of aggradation in this otherwise degradational landscape. Despite their fragmentary nature, these deposits offer a means of studying the history of landscape development. To better understand this history, we have reconstructed stratigraphic facies from borehole logs, mapped sedimentdispersal patterns from pebble counts, and identified fluvial processes from sedimentary features.

This report is an outgrowth of recent studies of gravel deposits of the South Platte River and its tributaries for the U.S. Geological Survey (USGS) Front Range Infrastructure Resources Project (Knepper, 2002). The stratigraphy of late Pleistocene and Holocene alluvium in the South Platte and the Cache la Poudre River valleys was delineated previously in valley cross sections (Lindsey, Langer, Cummings, and Shary, 1998; Langer and Lindsey, 1999). Additional sections showing the stratigraphy of valley fill in the South Platte River and some of its tributaries, principally Clear Creek and Bear Creek, were prepared for this report. The lithology of gravel, first mapped by Colton and Fitch (1974) and later by the Infrastructure Resources Project (Lindsey, 2003), is supplemented here by additional data and used to identify the provenance of gravel. Sedimentary features, described from gravel pits in late Pleistocene and Holocene alluvium of the South Platte (Lindsey, Langer, Cummings, and Shary, 1998) and Cache la Poudre River valleys (Langer and Lindsey, 1999), are redescribed and interpreted, and new information on sedimentary features in older Pleistocene alluvium is reported here.

\section{Quaternary Alluvium}

Quaternary alluvium of the Colorado Piedmont was subdivided and correlated by Hunt (1954) and Scott (1960, 1963, 1965) on the basis of superposition, physiographic position (elevation above stream level), and soil development. They (Hunt, 1954; Scott, 1960, 1963) also used fossils, volcanic ash beds, and radiocarbon dates to correlate some units. This system of subdivision was foreshadowed by the description and correlation of terraces, based on elevation above stream level, in the Cache la Poudre River valley (Bryan and Ray, 1940). However, Scott's (1960) subdivision has been the basis for correlation of Quaternary alluvium on most geologic maps of the region, including the South Platte and Cache la Poudre valleys (Colton, 1978; Trimble and Machette, 1979; Bryant and others, 1981; and references therein). The age of Scott's (1960) units has been revised (Madole, 1991) as additional radiometric dates became available. We have used the stratigraphic nomenclature of Scott (1960) as a framework for our descriptions and data. However, we recognize that the nomenclature has probably been incorrectly applied on some maps and may also be subject to limitations imposed by diachronous terrace formation (Bull, 1991) and differences in local drainage history caused by stream piracy (Ritter, 1987). 


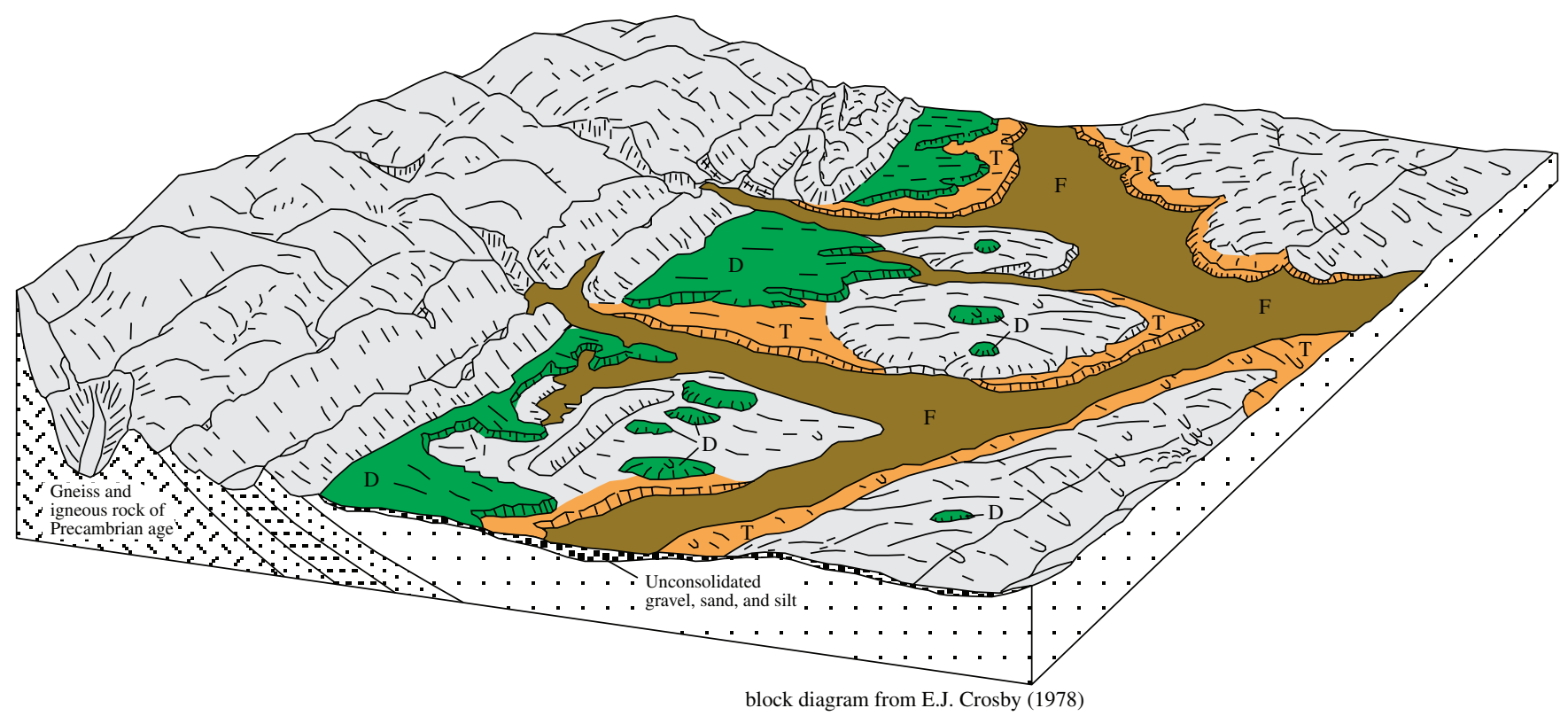

\begin{tabular}{|c|c|c|c|}
\hline \multicolumn{4}{|c|}{ EXPLANATION } \\
\hline AGE & SUR & ACE FEATURE & STRATIGRAPHIC UNIT \\
\hline $\begin{array}{l}\text { Holocene and } \\
\text { Pleistocene }\end{array}$ & $\Delta v$ & Dune fields & Eolian sand and silt \\
\hline Holocene & $\mathrm{F}$ & $\begin{array}{l}\text { Flood plain and } \\
\text { low terraces }\end{array}$ & $\begin{array}{l}\text { Post-Piney Creek and } \\
\text { Piney Creek Alluvium }\end{array}$ \\
\hline Late Pleistocene & $\mathrm{T}$ & Alluvial terraces & $\begin{array}{l}\text { Broadway and } \\
\text { Louviers Alluvium }\end{array}$ \\
\hline $\begin{array}{l}\text { Middle and early } \\
\text { Pleistocene, } \\
\text { Pliocene(?) }\end{array}$ & $\overline{\mathrm{D}}$ & $\begin{array}{l}\text { Dissected alluvial } \\
\text { fans and terraces }\end{array}$ & $\begin{array}{l}\text { Slocum, Verdos, } \\
\text { Rocky Flats and pre- } \\
\text { Rocky Flats Alluvium }\end{array}$ \\
\hline
\end{tabular}

Figure 1. Block diagram showing alluvium of the South Platte River and its tributaries. The explanation shows the geologic age, surface features, and stratigraphic units.

Three categories of alluvial units can be defined for the Colorado Piedmont by age, relative elevation, and degree of dissection (fig. 1). From oldest to youngest, they are (1) old dissected alluvial fans and terraces located near the mountain front and on divides between major streams, (2) alluvial-fill terraces, located along the margins of major stream valleys, and (3) flood plains and low terraces that comprise the modern valleys. Within these three broad categories, as many as eight alluvial units of Quaternary age and one of possible Pliocene age have been mapped (Colton, 1978; Trimble and Machette, 1979).

The oldest alluvial unit, the Pliocene (Blancan) Nussbaum Alluvium, is best exposed in the piedmont of southeastern and northeastern Colorado outside the study area (Scott, $1965,1982)$. In the study area, only a few remnants of preRocky Flats (Nussbaum?) alluvium have been mapped near the mountains (Wells, 1967; Van Horn, 1972; Scott, 1972) and on the divide east of the South Platte River (Soister, 1965a, 1965b). In contrast to fossil evidence for the Pliocene age of Nussbaum Alluvium in northeastern Colorado (Scott, 1982), no evidence is available to establish the age of pre-Rocky Flats Alluvium in the study area.
The early Pleistocene Rocky Flats Alluvium is the oldest and highest widespread unit in the study area. Some Rocky Flats Alluvium, including the type Rocky Flats east of the mouth of Coal Creek Canyon (Scott, 1960; Shroba and Carrara, 1996) and the roughly equivalent early(?) Pleistocene Alluvium of Table Mountain (fig. 2), located north of Boulder (Madole, Braddock, and Colton, 1998; Madole, in Dethier and others, 2003), was deposited as alluvial fans. Middle Pleistocene episodes of incision and lateral cutting formed terraces at two or more levels below the Rocky Flats surface. The fill of these terraces has been mapped as early middle Pleistocene Verdos Alluvium ( $640 \mathrm{ka})$ and middle Pleistocene Slocum Alluvium ( 240 ka). ${ }^{1}$

After deposition of the Slocum Alluvium, the South Platte River and its major tributaries cut new valleys and deposited the late middle Pleistocene Louviers ( 200-130 ka or less) Alluvium and the late Pleistocene Broadway ( 30-12

\footnotetext{
${ }^{1}$ Ages cited in this report are from Madole (1991); the age of the Verdos Alluvium is revised to reflect the revised age of the Lava Creek B ash (Lanphere and others, 2002); Lava Creek B ash occurs within the Verdos Alluvium (Izett and Wilcox, 1982).
} 
Stratigraphy, Lithology, and Sedimentary Features of Quaternary Alluvial Deposits, S. Platte River and Tributaries, Colo.

ka) Alluvium. These deposits are shown as terraces along major stream valleys in figure 1. The Louviers and Broadway Alluvium are correlated with Bull Lake and Pinedale glaciations, respectively (Madole, 1991; Madole, Van Sistine, and Michael, 1998). Louviers and Broadway Alluvium along major streams that head in the mountains, including the type Broadway Alluvium (Hunt, 1954; Scott, 1960), are composed mostly of gravel and sand. Louviers and Broadway Alluvium along streams that do not head in the mountains, including the type Louviers Alluvium (Scott, 1960, 1963), tend to contain more sand and silt than alluvium in mountain-source streams.

After the last glaciation, the South Platte River and its tributaries formed the low terraces of present-day valleys. The Holocene valley fill is usually divided into three parts: pre-Piney Creek, Piney Creek, and post-Piney Creek Alluvium (Scott, 1960, 1963). These units are distinguished on many geologic maps of the region but are discussed together as Holocene "flood plain and low terrace" alluvium in this report (fig. 1). Usually distinguished by topographic level, the Holocene units are essentially identical in appearance.

\section{Acknowledgments}

We thank the employees of Camas Cooley, City of Lakewood at Bear Creek Lake Park, Hall-Irwin Corporation, Lafarge North America, Inc., Pioneer Sand Company, Inc., and Stu Blattner, Inc., for granting access to examine gravel deposits on their properties. R.R. Shroba drew attention to reports containing seismic profiles and borehole logs of Rocky Flats Alluvium. During previous studies (Lindsey, Langer, Cummings, and Shary, 1998), Beta Analytic, Inc., Miami, Fla., conducted radiocarbon analysis of wood; L. Scott Cummings and T.E. Moutoux, Paleo Research Laboratories, Golden, Colo., identified pollen. E.M. Fisher conducted particle-size analyses of silt samples. J.F. Shary assisted in fieldwork, and other members of the USGS Front Range Infrastructure Resources Project provided inspiration, ideas, and assistance in various stages of the work. We thank R.F. Dubiel, R.F. Madole, G.R. Scott, and N.D. Smith for comments on drafts of the manuscript.

\section{Methods and Definitions}

\section{Stratigraphy}

The stratigraphy of valley fill was examined in detail for the South Platte River north of Denver (Lindsey, Langer, Cummings, and Shary, 1998), the Cache la Poudre River between Fort Collins and Greeley (Langer and Lindsey, 1999), and other tributaries of the South Platte. Sections (fig. 2) showing topography and sedimentary units in terrace fill were constructed by plotting surface profiles from topographic maps, locating wells and test holes on maps and sections, and plotting units described in borehole ${ }^{2} \operatorname{logs}$. Borehole logs (Jenkins, 1961; Schneider and Hershey, 1961; Schneider, 1962; McConaghy and others, 1964), originally used for hydrologic studies (Smith and others, 1964), contain descriptions of grain size and other features that permit identification of laterally persistent sedimentary units. Using borehole logs, we classified sediments by grain size ${ }^{3}$ as "gravel>sand" (gravel predominates over sand), "sand>gravel" (sand predominates over gravel), "sand," and "silt and clay," as described in borehole logs. Some interpretation and generalization of logs was required to identify coherent units. Adjacent intervals having similar descriptions were lumped together even though they are described separately in logs. Descriptions of silt and clay vary so much that the two classes of particle size were combined. Intervals with descriptions such as "sand, very fine gravel, scattered cobbles" were classified as "sand>gravel;" if the context of the description indicated that gravel was the dominant or sole constituent, the interval was classified as "gravel>sand." With the aid of geologic maps, some surficial deposits of sand, silt, and clay were correlated with eolian deposits. Other surficial deposits, described in logs as "soil" and "loam," but also including overbank deposits on flood plains, colluvium, and artificial fill, were assigned to a single category on sections. For portions of the South Platte and Cache la Poudre Rivers, stratigraphic units identified in borehole logs were verified and described in detail from gravel pits (Lindsey, Langer, Cummings, and Shary, 1998; Langer and Lindsey, 1999).

Approximate locations of sections are provided in figure 2 for easy reference, but most sections can be located more precisely by referring to the labels for each borehole. These labels follow the convention described in the Colorado Water Conservation Board Basic Data Reports (e.g., Schneider and Hershey, 1961) and in Smith and others (1964). Each borehole label begins with a single uppercase letter that designates the northeast (A), northwest (B), southwest (C) or southeast (D) quadrant as determined by the intersection of the sixth principal meridian and the 40th parallel base line. Numbers after the uppercase letter designate township, range, and section. Lowercase letters designating successive quarter divisions follow the section number. For example, C5-69-4abcd is read as the southwest quadrant, township 5 south, range 69 west, section 4. Lowercase letters are read as the northeast $1 / 4$ (a) of section 4 , northwest $1 / 4$ (b) of a, southwest $1 / 4$ (c) of $b$, and southeast $1 / 4$ (d) of c, in descending scale of quarters. Two geologic maps, for the Commerce City and Arvada quadrangles (Lindvall,

\footnotetext{
2 "Borehole" as used herein refers to both wells drilled for water and test holes drilled for geologic information.

3 Terms for grain size in this report follow the Udden-Wentworth scale (Pettijohn, 1975) with the caveat that all descriptions are based on visual estimation unless otherwise noted; estimation methods and definitions of grain size for borehole logs are not documented in the source literature; gravel is composed predominantly of particles $>2 \mathrm{~mm}$ in diameter; sand is $0.0625-2$ $\mathrm{mm}$ in diameter; silt and clay (undifferentiated) are $<0.0625 \mathrm{~mm}$ in diameter.
} 


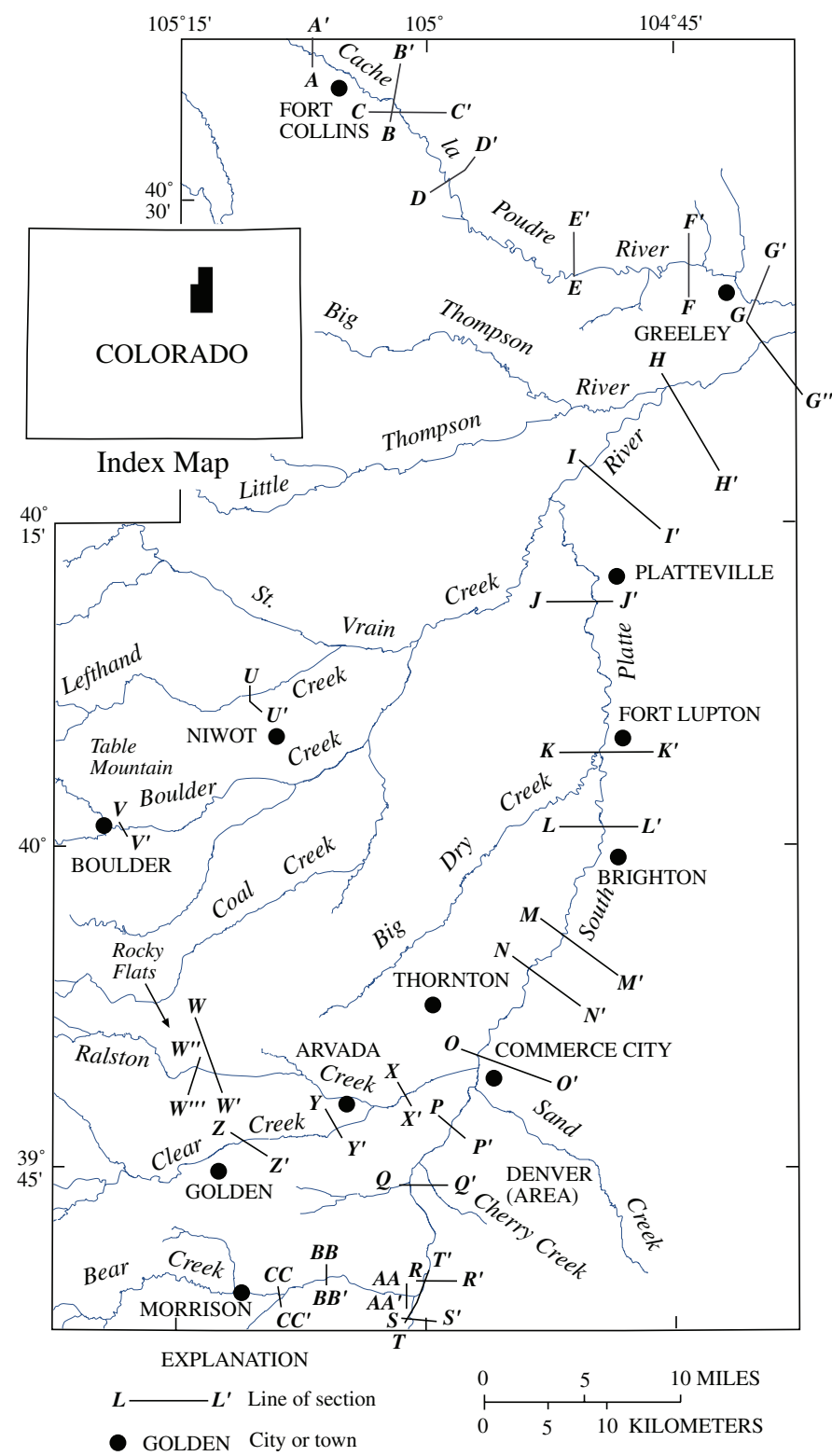

Figure 2. Map showing location of sections through valley fill, South Platte River and tributaries.

1979a, 1979b), also show borehole locations. Two section lines, $W$ - $W^{\prime}$, and $Z-Z^{\prime}$, follow features shown on the Golden $712^{\prime}$ quadrangle (Van Horn, 1972).

To aid description of stratigraphic units, particle size of gravel beneath the flood plain and low terraces of the South Platte River was measured north of Denver and, for the Cache la Poudre River, between Fort Collins and Greeley (Lindsey, Langer, Cummings, and Shary, 1998; Lindsey and Langer, 1998; Langer and Lindsey, 1999). Samples were collected from trenches across individual gravel units exposed in gravel pits. Sampling plans, described in the above-cited reports, were used to ensure representative samples and precision. Particle sizes were determined using sieves having mesh openings of $3 / 16,3 / 8,3 / 4,1 \frac{1}{2}$, and 3 inches. ${ }^{4}$ Sieve data were used to measure contrasting particle size distributions in gravel units and, in the Cache la Poudre River valley, downstream decrease in particle size of gravel (Lindsey, Langer, and Shary, 1998; Langer and Lindsey, 1999).

The morphology of alluvial units at Rocky Flats and Ralston Creek was examined using aerial photographs, digital elevation models (DEMs), and maps of alluvium thickness and paleotopography. Maps showing the thickness of alluvium and subsurface topography at Rocky Flats (Knepper, 2005) were prepared from borehole data and geophysical profiles (Dames \& Moore, 1981; EG\&G Rocky Flats, Inc., 1991) and from digitized outcrop elevations of the base of the Rocky Flats Alluvium (Schwochow and others, 2000). Paleotopography beneath the Verdos Alluvium of Ralston Creek was determined from aerial photographs and inspection of gravel pits.

Alluvial terrace terminology used in this report was modified from Bull (1991). A planar surface (tread) defines the top of a terrace; a step (riser) separates each terrace from its neighbors. Fill terraces (depositional terraces of Ritter, 1986) form by aggradation (vertical accretion) followed by incision. Thin fills (erosional terraces of Ritter, 1986) form by lateral cutting and back-filling (lateral accretion). For some terraces, shallow channel fills and lag deposits of pebbles and cobbles rest on a surface cut in bedrock. These stream-cut surfaces are sometimes called "straths" or, if incised, "strath terraces" (Bucher, 1932). Because straths are considered to be nearly flat, a characteristic that is difficult to demonstrate, such rock-cut surfaces are merely described in this report. Comparable surfaces, cut in alluvial fill, are called "fill cuts" or, if incised, "fill-cut terraces."

\section{Clast Lithology and Roundness}

Maps were prepared to identify the source and dispersion paths of individual clast lithologies. Pebble counts (fig. 3) were first compiled from Colton and Fitch (1974) and integrated with data collected for the Front Range Infrastructure Project (Lindsey and Shary, 1997; Lindsey, Langer, and Shary, 1998; Langer and Lindsey, 1999) to develop clast lithology maps (Lindsey, 2003). These data are available online (Lindsey, 2001). Since that compilation, new data were collected to extend coverage west of the South Platte River south to Bear Creek and to fill gaps and verify compiled data. Also, published data from the Rocky Flats (Malde, 1955; Shroba and Carrara, 1996) and Golden areas (Van Horn, 1976) were added.

We used the classification criteria of Lindsey and Shary (1997) for identification of pebble lithology. In the classifica-

\footnotetext{
${ }^{4}$ Sieves with openings in English units were used to collect data consistent with practices of the U.S. aggregate industry; metric equivalents of the series $3 / 16,3 / 8,3 / 4,1 \frac{1}{2}$, and 3 inches are 4.762, 9.525, 19.05, 38.10, and $76.20 \mathrm{~mm}$, respectively.
} 
Stratigraphy, Lithology, and Sedimentary Features of Quaternary Alluvial Deposits, S. Platte River and Tributaries, Colo.

tion process, expediency required that "granite" include other holocrystalline igneous rocks of intermediate composition, such as quartz monzonite, granodiorite, and syenite. In addition, consistency required that all rocks classified as "granite" be nonfoliated, even though foliated variants have been mapped in the source area (e.g., Bryant and others, 1981). These conventions appear to have been followed in other studies (e.g., Colton and Fitch, 1974). It is not feasible to correctly assign hundreds of pebbles to variant compositions without detailed petrographic analysis. If predominant grain size approaches or exceeds approximately 1 centimeter $(\mathrm{cm})$, the rock was classified as "pegmatite." Most pegmatite encountered in pebbles consists largely of quartz and potassium feldspar; large crystals of potassium feldspar with graphic intergrowths of quartz were also classified as pegmatite.

Several inconsistencies in classification of other rock types constrain the use of pebble counts from earlier studies in mapping clast lithology. Most problems arise from differences in classifying volcanic and metamorphic rocks; thus, categories for these vary from one study to another (e.g., compare Colton and Fitch, 1974, with Lindsey, Langer, and Shary, 1998, and Langer and Lindsey, 1999). For this investigation, all volcanic rocks were combined, and the mafic rocks amphibolite, biotite schist, and diabase (including metadiabase) were combined. Vein quartz and quartzite, both crucial to understanding sediment dispersal in the South Platte drainage system, were not distinguished in some studies (e.g., Colton and Fitch, 1974). Although vein quartz and quartzite were combined to map these resistant rocks for an analysis of gravel quality for use in aggregate (Lindsey, 2003), only data where these were distinguished was used here to map clast dispersion paths in alluvium. Finally, data on roundness, useful in comparing transport distance of pebble populations, are available only from recent studies (Lindsey and Shary, 1997;

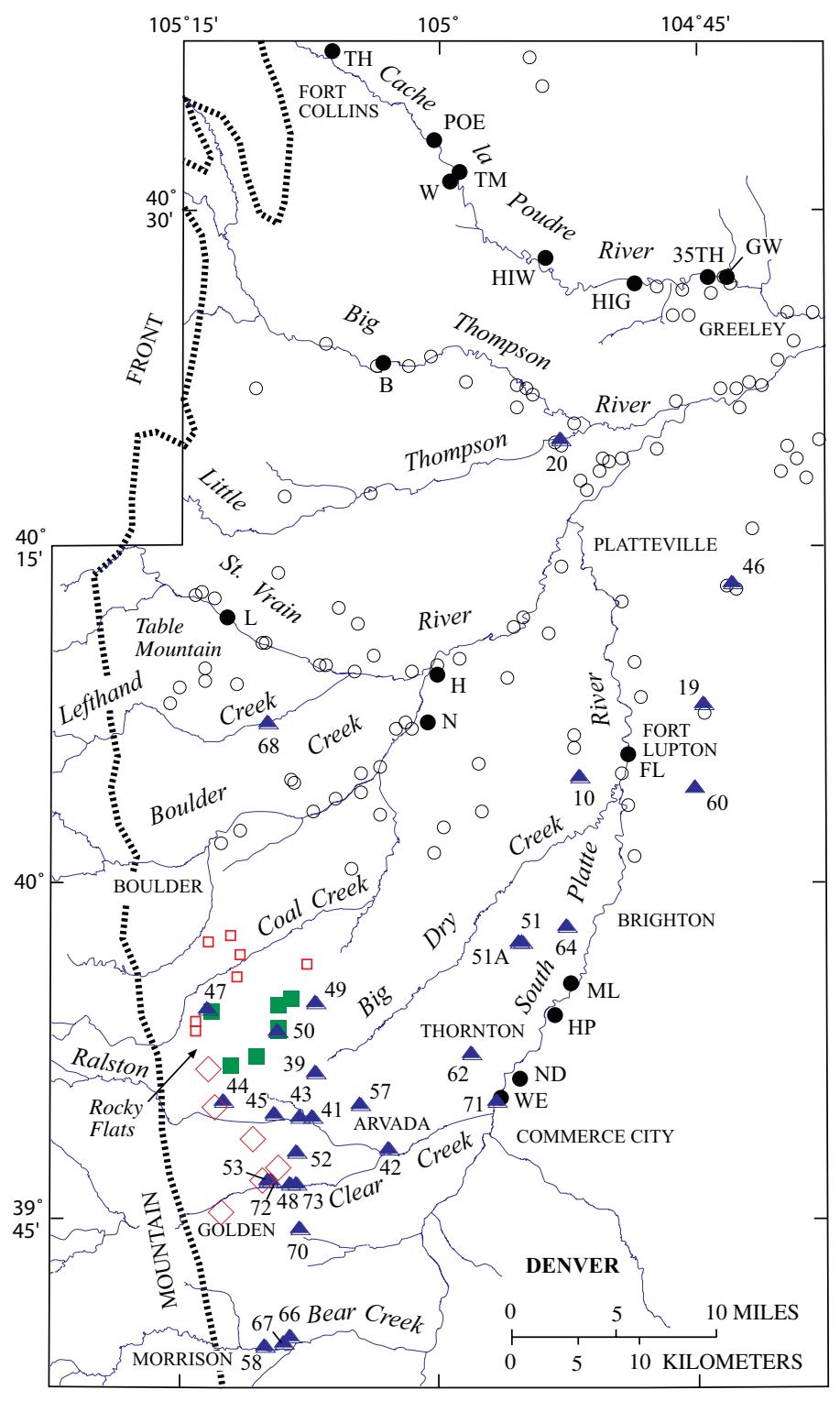

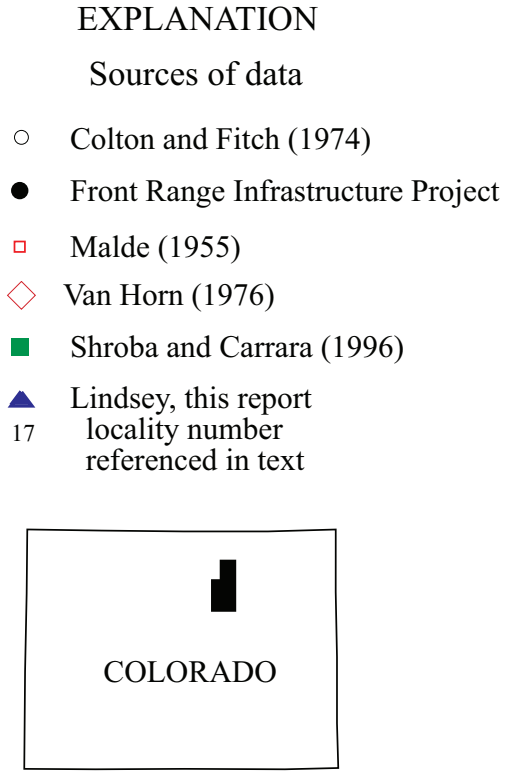

Figure 3. Map showing sources of data on lithology and rounding of gravel clasts and sedimentary features, South Platte River and tributaries. Hachures show approximate location of mountain front. Front Range Infrastructure Project localities are gravel pits in the Cache la Poudre River valley: TH, Taft Hill pit; POE, Port-of-Entry pit; TM, Timnath pit; W, Weitzel pit; HIW, Hall-Irwin Windsor pit; HIG, Hall-Irwin Greeley pit; 35th, 35th Street pit; GW, 25th Street pit (Langer and Lindsey, 1999). Localities in the South Platte River valley: ML, Mann Lake pit; HP, Howe pit; and ND, North Dahlia pit (Lindsey, Langer, and Shary, 1998); and other stream valleys: $B$, Brose pit; $\mathrm{H}$, Ham pit; L, Lyons pit; N, Nelson pit. Gravel bar sampling sites: FL, at Fort Lupton and WE, at Welby (Lindsey and Shary, 1997). 
Lindsey, Langer, and Shary, 1998; Langer and Lindsey, 1999; this report).

In preparing maps of clast lithology, pebble counts of Slocum and older alluvium were separated from counts of Louviers and younger alluvium. The two categories are shown together on maps but are distinguished by symbols. An analysis of pebble counts by age of alluvium showed significant differences in clast lithology versus age of alluvium, with Slocum and older alluvium containing more vein quartz + quartzite than younger alluvium (Lindsey, 2003). Such differences may reflect differences in source and in degree of weathering. Most samples of Slocum and older alluvium were taken from shallow, weathered exposures, but even in deep pits, alteration and disintegration of clasts are evident. Counts include only intact pebbles; disintegrated pebbles are not easily collected for identification. A study of clast weathering in gravel from the divide between Coal Creek and South Boulder Creek and the flood plain of South Boulder Creek showed significant weathering and disintegration of granitic and gneissic clasts in gravel on old surfaces above the flood plain (Laughon, 1963). Disintegration by selective weathering of lithologies will bias pebble counts in favor of resistant clasts in Rocky Flats, Verdos, and probably Slocum Alluvium.

To minimize particle-size effects, the same size fraction should be used for all pebble counts. The data used here come close to that condition, but do not meet it perfectly. For new data collected for this study, pebble lithology and roundness were estimated by classification of approximately 100 or more pebbles, approximately 1-3 inches (25-76 mm) in long dimension, at each locality. Sampling consisted of selecting approximately the first 100 pebbles encountered from a defined area or a traverse across an exposure. In studies of gravel in the South Platte and Cache la Poudre Rivers, the 0.75 - to 1.5 -inch (19.05- to $38.10-\mathrm{mm}$ ) sieve fraction was used (Lindsey, Langer, and Shary, 1998; Langer and Lindsey, 1999). For a study of gravel bars of the South Platte River, the 0.75 - to 2.0 -inch (19.05- to $50.80-\mathrm{mm})$ sieve fraction was used (Lindsey and Shary, 1997). Most pebble counts reported by other workers (e.g., Colton and Fitch, 1974) do not specify a size range for clasts. For all studies by the authors, pebbles were washed in water and examined with a hand lens for rock identification.

Pebble roundness (the degree to which pebbles lack angular corners) was estimated visually using the method of Pettijohn (1975, fig. 3-24). In this method, pebbles are assigned letters A-E for angular to well rounded. Average roundness, percent angular plus subangular, and percent rounded and well-rounded clasts were compared for each stream to assess the degree of downstream variation and differences in rounding among streams having mountain reaches of varying length and character. In addition, lithology and roundness were combined in simple data matrices to identify and compare clast populations. In the Appendix to this report, such lithology-roundness matrices are analyzed as contingency tables to identify combinations of clast lithology and roundness that characterize populations of differing provenance.

\section{Sedimentary Features}

Sedimentary features, which include both bedforms and their bounding surfaces, were identified in pits, road cuts, and stream banks. Most observations were made by mapping and photographing walls of gravel pits. The youngest alluvial deposits studied were Holocene and late Pleistocene alluvium of the South Platte (Lindsey, Langer, Cummings, and Shary, 1998) and Cache la Poudre Rivers (Langer and Lindsey, 1999). Terrace fill of Louviers Alluvium was examined in pits along Clear Creek (locality 72, fig. 3) and Bear Creek (locality 58). Other deposits studied include thin terrace fill of Verdos Alluvium along Ralston Creek (locality 44), alluvial-fan sediments of Rocky Flats Alluvium at Rocky Flats (locality 47), and thin terrace fill of ancestral Clear Creek (locality 57).

In describing sedimentary features of gravel-bed river deposits, we have used simple terms, most of which are in common use but are defined here for clarity. Although the terms are used here in a descriptive sense, they carry unavoidable genetic connotations. Terms for bounding surfaces of increasing scale are "bedding plane (surface)," "accretion (herein called reactivation) surface," and "channel erosion surface" (Bristow, 1996). In fluvial deposits, bedding surfaces are boundaries between structures of individual and stacked bedforms such as sets of cross-lamination and crossbedding and intervals of horizontal laminae deposited on bar tops and channel bottoms. Reactivation surfaces ${ }^{5}$ bound sets of accretionary laminae on bars; they are small scour surfaces formed when discharge fluctuates or when the channel shifts position slightly (Willis, 1993). In contrast, channel erosion surfaces are local disconformities formed by channel scour; channel erosion surfaces bound channel and bar deposits. Because these three scales of surfaces can pass laterally from one to another (Bristow, 1996), and because the structure of channel and bar deposits of gravel-bed streams can be complex, some overlap and confusion about which term to apply is unavoidable. The general term "scour" is used here to describe the process of sediment excavation by flowing water in channels and on bars, and for erosional depressions of any size created by that process. The term "erosional disconformity" is used for laterally extensive scoured surfaces, such as the bottoms of fill-cut terraces and paleovalleys.

For flow-generated bedforms in alluvial channels, terminology proposed by the SEPM Bedforms and Bedding Structures Research Group (Ashley, 1990) was used as much as possible. Ripples and dunes, which are best developed in sand and sandy gravel, are bedforms that present themselves in two dimensions as cross-lamination and crossbedding, respectively; they differ only in scale. Dunes with curved crests form trough crossbedding; dunes with straight crests form planar crossbedding. Slipfaces of large in-channel dunes (also called

\footnotetext{
${ }^{5}$ Reactivation surfaces (Collinson, 1970) on bars have also been called "accretion surfaces" (Bristow, 1996) and "bedding disconformities" (Willis, 1993).
} 
Stratigraphy, Lithology, and Sedimentary Features of Quaternary Alluvial Deposits, S. Platte River and Tributaries, Colo.

"sand waves") and solitary bars are preserved as planar foreset laminae separated by laminated and cross-laminated apron and topset laminae (terminology of Crowley, 1983). In addition to ripples and dunes in sandy sediment, bedforms in coarse gravel include clast dams and ridges (Bluck, 1987) and clast clusters (Brayshaw, 1984); only clast clusters were observed in this study.

The term "bar" (equivalent to "macroform" of Crowley, 1983 ) is used for all channel forms an order of magnitude larger than bedforms. Because large in-channel dunes and sheets are often called "bars" in the literature (Ashley, 1990) and present themselves as braided channels at low stage (Smith, 1985), we include them with bars. Individual bars and bar types are difficult to recognize in gravel because they are modified extensively by scour after deposition (Smith, 1978). However, in some cases, the bounding surfaces and structure of gravel bars can be recognized.

\section{Stratigraphy}

\section{Terrace Formation and Correlation}

For most stratigraphic sections presented here, correlation of units is based on geologic maps and reports that use the nomenclature of Scott (1960). Although we use Scott's (1960) stratigraphic nomenclature for alluvial units in the study area, we recognize that using the nomenclature across a drainage system as large as the South Platte River risks miscorrelation. Scott's (1960) nomenclature has been applied on many maps by many workers (Colton, 1978; Trimble and Machette, 1979; Bryant and others, 1981; and references therein) and may not have always been consistently applied. Some apparent miscorrelations were encountered during the present study; they are discussed in the following pages. Other miscorrelations may have gone unrecognized. More generally, miscorrelation may stem from failure to recognize the mode of terrace formation or differences in stream history; these topics are discussed here.

One source of possible miscorrelation arises from the manner in which alluvial terraces form. Streams downcut their valleys (degradation) when stream power exceeds resisting power; streams deposit alluvium in their valleys (aggradation) when stream power is exceeded by resisting power (Bull, 1991). Stream power is primarily a function of discharge and slope; resisting power is primarily a function of the amount and size of bedload and the hydraulic roughness of the channel. Changes in these variables may force a stream across the equilibrium threshold between aggradation and degradation. When stream power equals resisting power, the stream maintains equilibrium between degradation and aggradation and the stream is said to be "at grade." When a stream crosses the threshold between degradation and aggradation, a time lag (reaction time) occurs before degradation or aggradation occurs; then, the stream erodes or deposits sediment (relax- ation time) until equilibrium is again reached (Schumm, 1977; Bull, 1991). Response times (the sum of reaction and relaxation times) vary with the severity of the threshold-crossing event and with other factors such as discharge and sediment load. Thus, even though streams may be affected by a regional event such as climate change, response times may differ among streams of different sizes, leading to nonsynchronous degradation and aggradation. In addition, degradation and aggradation proceed upstream simultaneously, with degradation occurring upstream from aggradation in the same stream. Thus, over some time interval, individual terraces are diachronous (Bull, 1991). The net result is that alluvial units in different parts of a drainage basin may not be truly correlative. Differences in age may be especially large between alluvial terrace sequences formed by large streams that head in glaciated mountain valleys and terrace sequences formed by small streams that head in the piedmont.

Aggradation and degradation are not always a response to external causes such as climate change or tectonism. Streams may respond internally (complex response of Schumm, 1977) by repeatedly crossing the threshold between aggradation and degradation before reaching final equilibrium. Complex response was first recognized in an example of base-level lowering (Schumm, 1977) but has since been extended to internal responses that follow other external causes such as climate change (Bull, 1991). In the example of Schumm (1977, summarized by Bull, 1991), initial lowering of base level during constant discharge caused an experimental stream to incise its channel. Channel incision upstream resulted in high sediment production as alluvium was mobilized, leading to aggradation downstream where the stream had reached local base level. As incision reached the headwaters, sediment production dropped, leading to renewed incision downstream. The result in nature is one or more small terraces that represent brief periods when a stream crosses the threshold between aggradation and degradation. Such terraces are not regionally correlative.

Conversely, external causes do not always lead to aggradation or degradation. An alternative response to an external cause is adjustment of channel pattern, as defined by sinuosity and bar type. Aggradation or degradation sometimes, but not always, accompanies these responses. Response by changing channel pattern alone is more likely in meandering than straight rivers. Such responses have been documented where streams cross active tectonic structures, have experienced base-level changes such as sea-level fall, or are joined by tributaries with contrasting sediment load (Mosley and Schumm, 2001).

Stream piracy is a second cause of miscorrelation of units across a drainage system. Piracy can be a major agency in excavation of bedrock and deposition of terrace fill in large intermontane basins (Ritter, 1987). If a low-gradient (and low bedload) stream on the piedmont captures a high-gradient (and high bedload) mountain stream near the mountain front, the low-gradient stream will begin to aggrade (Ritter, 1987). At some point, aggradation will raise the gradient of the capturing stream to a new state of equilibrium. If the threshold between 
aggradation and degradation is crossed without stopping at equilibrium, incision will leave a new terrace above the stream channel. In and near the study area, Scott $(1963,1972)$ and Van Horn (1976) have described examples of stream piracy near the mountain front, but some of these involve minor tributaries. North of Boulder, deposition of the Table Mountain alluvial fan was followed by two successive stream piracies (Madole, in Dethier and others, 2003). In this report, we postulate the abandonment of the Rocky Flats alluvial fan when Coal Creek captured the stream in Coal Creek Canyon from Big Dry Creek. The resulting terrace fills of Coal Creek and Big Dry Creek may not be correlative with those of neighboring streams, even though the fills of all streams have been identified with units in the existing system of nomenclature.

In the South Platte River drainage system, the most reliable correlations have been made for some occurrences of Verdos Alluvium. At five localities (including the type locality) east of the Front Range, the Verdos Alluvium can be reliably correlated because the Lava Creek B volcanic ash has been identified in the Verdos (Izett and Wilcox, 1982). Ash beds in Verdos Alluvium at four additional localities belong to the Pearlette family (Scott, 1963; Izett and Wilcox, 1982); some probably are correlative with Lava Creek B ash. Until other quantitative estimates of terrace age are available for the South Platte drainage system, the best available alternative to correlation by ash beds is comparison of soil profiles on relict surfaces (Machette, 1977).

\section{South Platte River Valley}

Alluvial terraces and deposits lie at nine topographic levels along the valley of the South Platte River and its tributaries. From highest to lowest, these deposits are pre-Rocky Flats, Rocky Flats, Verdos, Slocum, Louviers, Broadway, and Holocene (pre-Piney Creek, Piney Creek, and post-Piney Creek) Alluvium (Colton, 1978; Trimble and Machette, 1979; and references therein). For most valley sections, the oldest units (pre-Rocky Flats through Slocum) are not close enough to the river to be shown. On sections in the Denver area (fig. 4 ), terrace treads underlain by Louviers Alluvium lie about 21-24 m above the modern valley of the South Platte River. Terraces underlain by Broadway Alluvium range from about $9 \mathrm{~m}$ above the modern valley near Denver to about $6 \mathrm{~m}$ at Fort Lupton and Brighton. In the Denver area, Louviers and Broadway terrace fill consists of coarse pebble gravel, but north of Brighton, the Broadway terrace fill is sandy.

The Broadway terrace forms a broad alluvial plain that extends along the eastern side of the South Platte from Denver past Greeley (fig. 4). This large fill terrace represents major aggradation, probably in response to increased sediment production upstream. Although the upper part of the terrace fill is assigned to the Broadway Alluvium, the lower part may belong to Louviers Alluvium (Lindvall, 1979a; McConaghy and others, 1964). If so, the terrace fill is the composite result of sediment production following two glacial retreats, the
Pinedale (Broadway) and the Bull Lake (Louviers). Using stratigraphic relationships, including soils at scattered pits and exposures, as well as fragmentary fossil evidence, Hunt (1954) concluded that the Broadway Alluvium at Denver (late Wisconsin gravel of Hunt, 1954) was underlain by coarse cobble gravel of Louviers Alluvium (early-Wisconsin-age gravel of Hunt, 1954). Hunt (1954) reports about 0.3-1 m of sand between his late Wisconsin and early Wisconsin gravels; he interpreted the sand as reworked from eolian deposits and correlated it with eolian sand and silt east of the South Platte River valley. Although we have not studied the terrace fill in gravel pits to test Hunt's (1954) two-fold age of terrace fill, the division is not supported by some relationships seen in sections (fig. 4) and discussed in the following pages.

Gravel beneath the Broadway terrace is as much as 15 $m$ thick on either side of U.S. Highway 85 north and south of Brighton (fig. 4, sections $K-K^{\prime}, L-L^{\prime}$, and $M-M^{\prime}$ ). This concentration of gravel coincides with a small depression in bedrock that probably marks the position of a major channel during Broadway or earlier time. The vertical continuity of this channel gravel suggests that the entire fill here belongs to a single period of aggradation. East of the coarse gravel, the proportion of sand increases and alluvial gravel appears to intertongue with sand, silt, and clay. Major depressions in bedrock beneath the valley fill north of Brighton may also mark former positions of the South Platte channel during Pleistocene time (fig. 4 , sections $G^{\prime}-G^{\prime \prime}$ through $J-J^{\prime}$ ). The section (fig. 4, section $\left.Q-Q^{\prime}\right)$ drawn across the valley of the South Platte and Cherry Creek at 8th Avenue in Denver reveals a major paleovalley fill beneath the Broadway terrace (see also Robson, 1996). We do not know whether all of these channels were carved during Broadway time or previously.

Laterally extensive layers of sand, silt, and clay can be traced through much of the alluvium beneath the Broadway terrace tread. Some of these layers are complex packages of fine-grained sediment that vary in particle size; they represent generalization of the detailed descriptions in borehole logs. Some layers may be overbank fines or mud that filled abandoned channels; others may be eolian. From Denver to Greeley, layers of sand, silt, and clay in and at the top of the Broadway terrace fill appear to be laterally continuous with deposits of eolian sand and silt that mantle upland surfaces on the east side of the river (fig. 4). At many places east of the river, longitudinal dune forms, visible on aerial photographs, confirm the eolian origin of upland deposits. However, from Brighton to Platteville, a narrow strip of alluvial sand and silt has been mapped along the eastern border of the South Platte River valley and in adjacent small tributary valleys (Soister, 1965a, 1965c). Although this strip of alluvial sediment may contain minor amounts of eolian deposits, it prevents certain correlation between fine-grained sediment in the valleys and upland eolian sediment. Near Denver, loess and eolian sand directly overlie the Broadway terrace (Lindvall, 1979a; Shroba, 1980). Eolian sand of latest Pleistocene age, dated by radiocarbon dates and Folsom artifacts, overlies the Broadway terrace east of Greeley (Madole, 1995). 

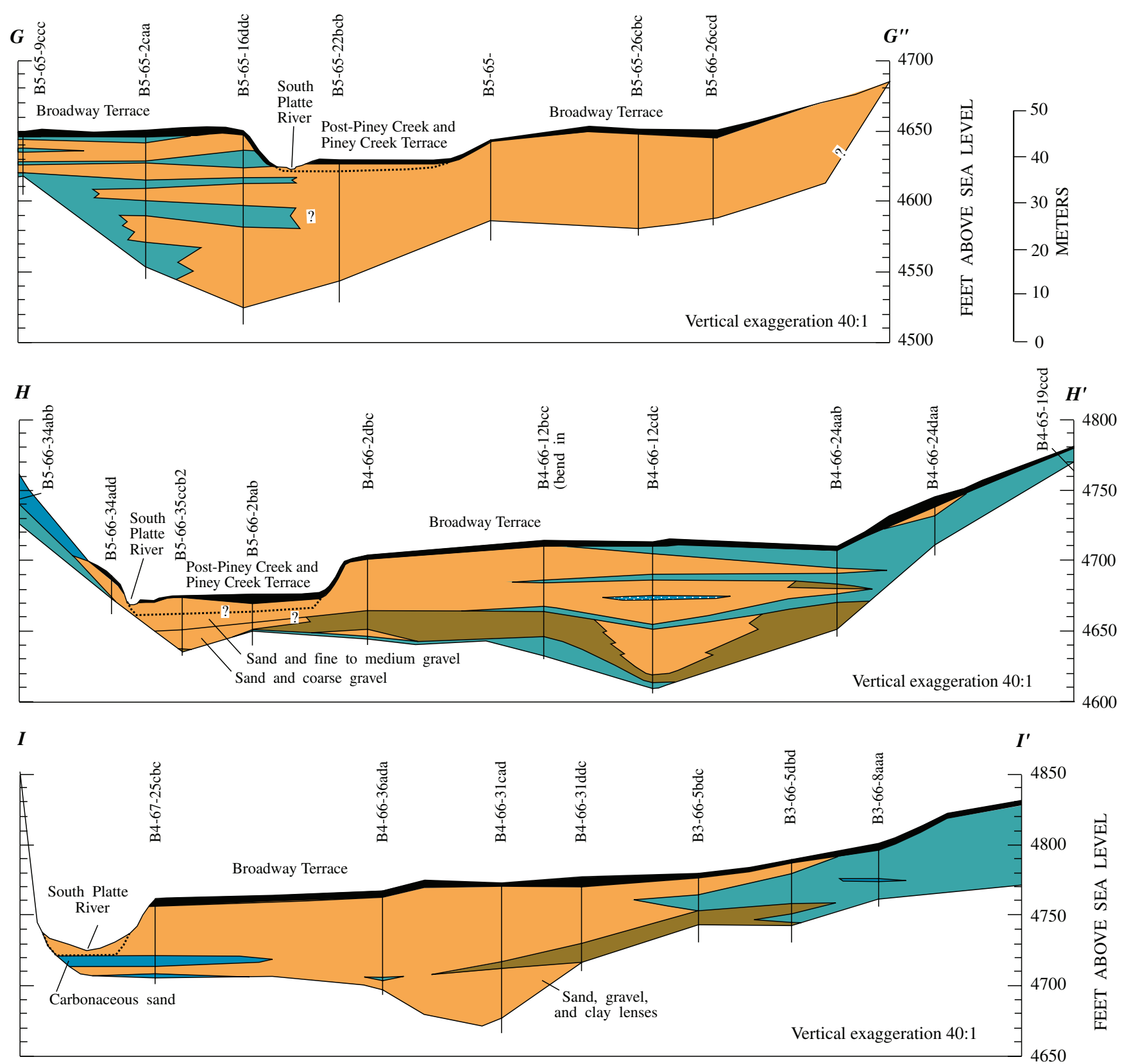

\section{EXPLANATION}
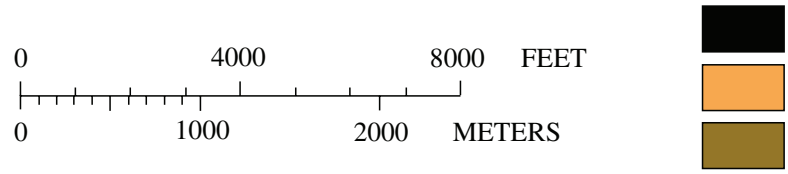

Soil, colluvium, overbank silt, and artificial fill

Sand $>$ gravel

Silt and clay

Gravel > sand

Sand

Base of Holocene (estimated)

Figure 4. Sections through alluvial fill of the South Platte River valley, Greeley to Denver, Colo. G'-G", H-H', I-I', from Greeley to Platteville, Colo., based on borehole logs by Schneider (1962); J-J', K-K', L-L, $M-M^{\prime}, N-N^{\prime}$, and $0-O^{\prime}$, from Platteville to Commerce City, Colo., based on geologic maps by Lindvall (1979a) and Soister (1965a, 1965b, 1965c) and borehole logs by Schneider (1962); $P-P^{\prime}, Q-Q^{\prime}, R-R^{\prime}, S-S^{\prime}$, and $T-T^{\prime}, D e n v e r$ area, based on geologic maps by Lindvall (1978) and Shroba (1980) and borehole logs by McConaghy and others (1964). Qlo, Louviers Alluvium; Qp, Piney Creek; Opp, post-Piney Creek; Qes, eolian sand, silt, and clay. 

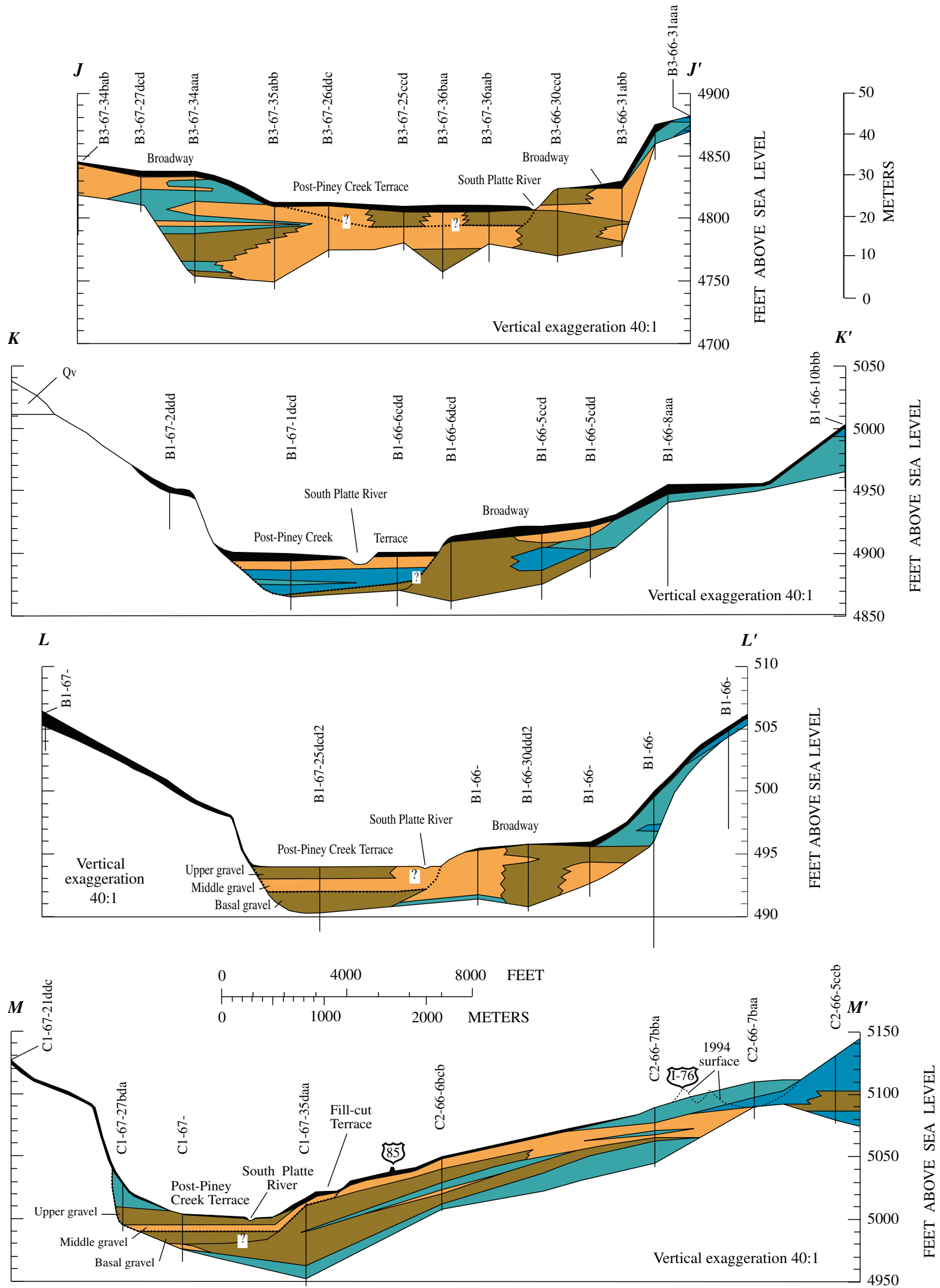

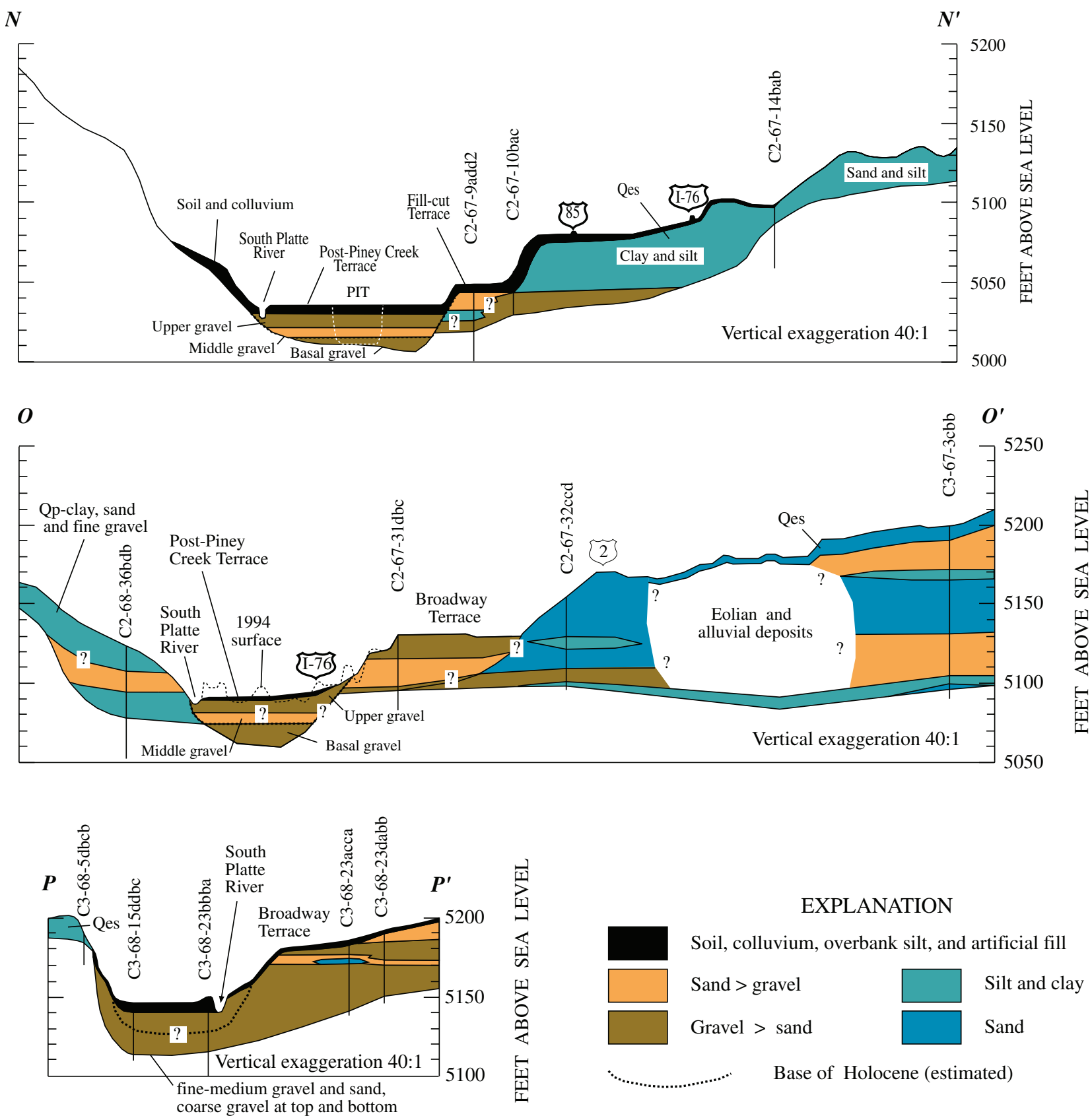

\section{EXPLANATION}

Soil, colluvium, overbank silt, and artificial fill $\square$ Sand $>$ gravel $\quad \square \quad$ Silt and clay $\square$ Gravel $>$ sand $\quad \square$ Sand

Base of Holocene (estimated)

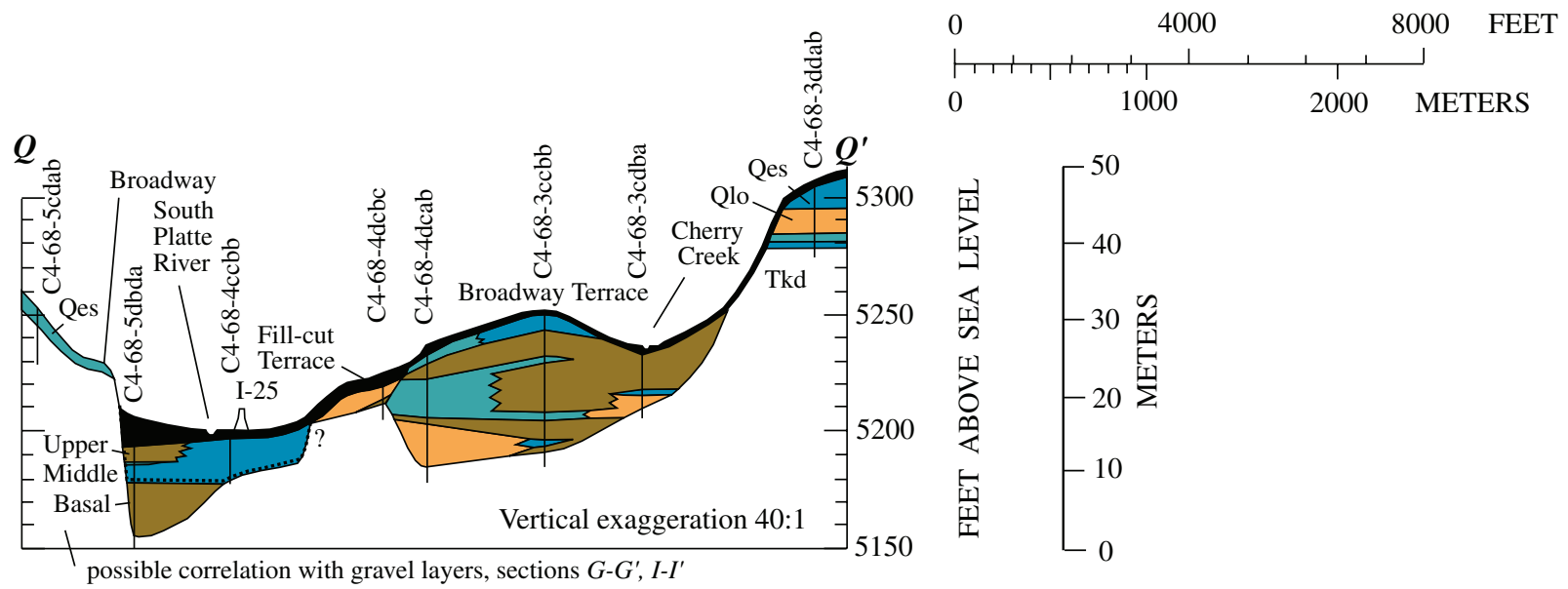




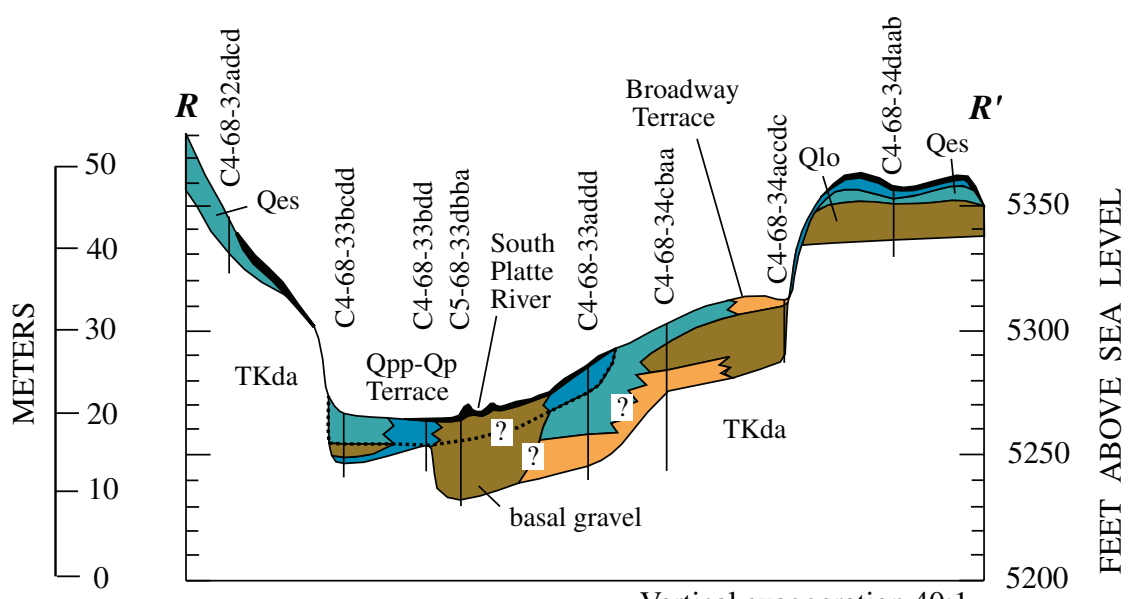

\section{EXPLANATION}

Soil, colluvium, overbank silt, and artificial fill

Sand $>$ gravel

Gravel > sand

Base of Holocene (estimated)

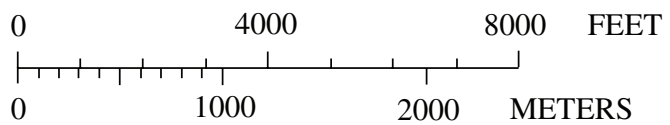

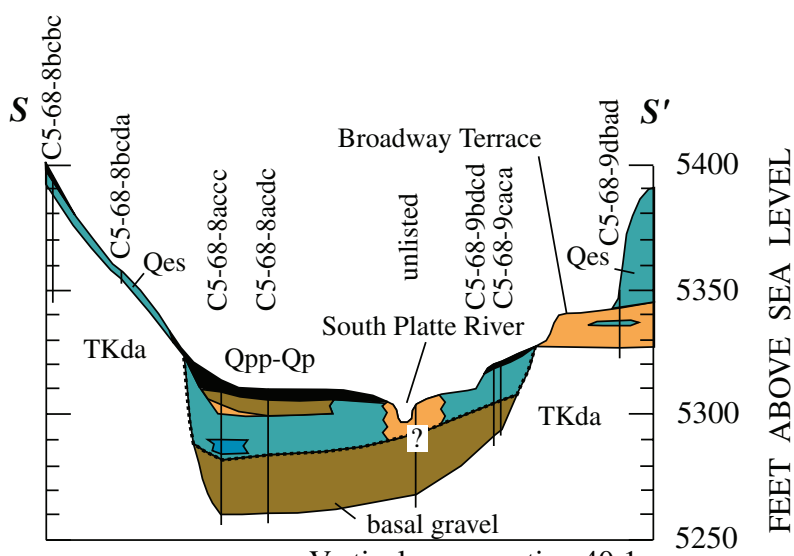

Vertical exaggeration 40:

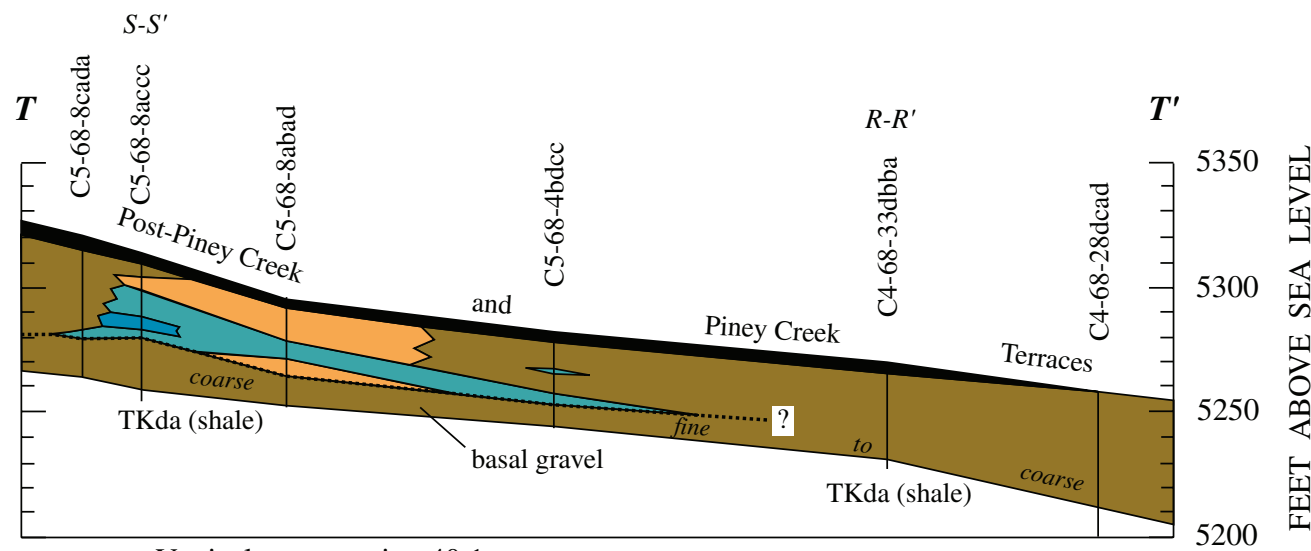

Vertical exaggeration 40:1

At some places, notably between Denver and Brighton, the upper fill of the Broadway terrace is composed of as much as $15 \mathrm{~m}$ of sand, silt, and clay (fig. 4, sections $M-M^{\prime}$ and $N-N^{\prime}$ ). East of the confluence of Clear Creek with the South Platte River, as much as $15 \mathrm{~m}$ of sand and silt also interfingers with alluvial gravel and covers the abandoned alluvial valleys of the ancestral South Platte River and Cherry Creek (fig. 4, section $\left.O-O^{\prime}\right)$. The locations of these valleys, not apparent in section $O-O^{\prime}$ because borehole logs are too widely spaced, are shown by Lindvall (1979a), Smith and others (1964), and Robson (1996).

The flood plain and associated low terraces of Holocene (Piney Creek and post-Piney Creek) Alluvium occupy a narrow valley, here designated the "modern valley," which is less than half the width of the South Platte River valley defined by the Broadway terrace. These deposits consist of complexly interleaved sand and gravel. North of Denver, the base of the modern valley appears to have been incised only slightly 
Stratigraphy, Lithology, and Sedimentary Features of Quaternary Alluvial Deposits, S. Platte River and Tributaries, Colo.

below the base of the Broadway terrace fill. Near Denver, however, the modern valley has been incised into bedrock well below the base of the Broadway terrace fill (fig. 4, sections $Q-Q^{\prime}, R-R^{\prime}$, and $\left.S-S^{\prime}\right)$.

The stratigraphy of the modern valley fill has been studied in detail between Denver and Fort Lupton (fig. 4, sections $K-K^{\prime}$ through $O-O^{\prime}$ ), where three gravel units have been distinguished. The gravel units are, from bottom to top, the basal coarse gravel, the middle sandy gravel, and the upper gravel (contains interbedded sand in places) (Lindsey, Langer, Cummings, and Shary, 1998). The three gravel units, described in detail under "sedimentary features," can be traced in borehole logs and gravel pits as far north as Fort Lupton, where all three are sandy. The lower and middle units are yellowish brown (Munsell color). The upper gravel is commonly grayish brown (Munsell color) and locally contains cottonwood and willow logs. Radiocarbon ages of wood from logs in the upper gravel, determined by Beta Analytic, Miami, Fla., show that some of the upper gravel is only a few hundred years old (Lindsey, Langer, Cummings, and Shary, 1998). Pollen (identified by L.S. Cummings and T.E. Moutoux, Paleo Research Laboratories, Golden, Colo.) from silt lenses at the base of the upper gravel and from the middle sandy gravel is from native plants that grow along stream banks today. Thus, at least some of the middle gravel also may be Holocene in age. Details of methods, data, and correlation of dated units are described in Lindsey and others (1998a).

The age of the basal coarse gravel is here inferred to be latest Pleistocene (late Broadway), when the modern valley was incised below the base of the Broadway terrace fill. The coarse (pebble and cobble) size of the basal gravel is consistent with transport in a stream of greater discharge, perhaps fed by glacial meltwater, than that of the Holocene South Platte River. Fossil teeth and bone fragments of mammoths, camels, and horses are recovered during gravel mining in the modern valley. The fragmentary nature of these remains is sufficient evidence to indicate that they have been transported from the site where the animals died; some may even have been reworked from older alluvium. We saw one such collection from the Howe pit (HP, fig. 3), north of Denver. Scott (1962) lists Pleistocene fossils from a gravel-dredging operation in valley fill of the South Platte River in the Littleton $712^{\prime}$ quadrangle, south of Denver. Although not observed in place, these Pleistocene fossils almost certainly come from the basal gravel. Most authors (e.g., Scott, 1962; Lindvall, 1978, 1979a) assign much of the gravel in the modern valley, including the basal unit, to the Louviers Alluvium. However, this assignment is not supported by incision of Broadway terrace fill and deposition of the basal gravel on bedrock below, as shown by our cross sections, and is not required by the fossil evidence.

On the sections of the South Platte valley, a dotted line was drawn to show the most likely (but approximate) separation of alluvial deposits of Holocene age from deposits of Pleistocene age. Where the stratigraphy is well defined, this line is placed at the base of the middle sandy gravel. In sandy sections north of Brighton, and on some all-gravel sections at Denver, the location of the line is problematic but has been added speculatively for illustrative purposes. If the lines are located correctly, alluvium of probable Holocene age does not extend to bedrock in most places but is separated from bedrock by the layer of coarse gravel interpreted to be of latest Pleistocene age.

The age of small terraces near Denver, mapped as Piney Creek Alluvium (fig. 4, $M-M^{\prime}, N-N^{\prime}$, and $Q-Q^{\prime}$ ), is unclear. The terraces are typically small, restricted to reaches between tributary mouths, and located about 3-5 $\mathrm{m}$ above the modern valley floor and below the Broadway terrace (Lindvall, 1978, 1979a; Shroba, 1980; Scott, 1962). The Piney Creek Alluvium has long been considered Holocene in age and was dated as such in tributary valleys including the type locality (Hunt, 1954; Scott, 1963). Commonly, the Piney Creek Alluvium of tributaries extends onto Holocene fill of the South Platte. In contrast, terraces mapped as Piney Creek but not located at tributary mouths may be late Pleistocene fill-cut terraces. If so, these terraces represent a pause during latest Pleistocene incision of the modern valley.

Histograms of particle size for the three gravel units show that stream power of the South Platte varied considerably in latest Pleistocene and Holocene time (fig. 5). The coarse pebble and cobble sizes of the basal gravel reflect the power of the stream that cut the modern valley. This deposit is interpreted as a lag composed of the cutting tools of incision. After discharge from retreating Pinedale glaciers ceased and downcutting reduced stream gradient downstream, stream power was insufficient to continue moving the bedload, and a coarse lag was left at the channel bottom. At the same time, however, as downcutting progressed upstream, it entrained valley alluvium and increased sediment production, leading to aggradation (complex response) downstream. The middle sandy gravel, which conformably overlies the basal gravel downstream from Denver, may be the record of this response. Although available information indicates that incision occurred in latest Pleistocene time and aggradation of the middle unit occurred in Holocene time, the possibility that aggradation began downstream while incision progressed upstream suggests that the middle gravel unit may cross the Pleistocene-Holocene boundary. Alternatively, the middle sandy gravel may represent introduction of abundant sediment stripped from hillsides in response to Holocene climate change. After deposition of the middle gravel, the river approached equilibrium and began cutting and backfilling laterally across its valley. The record of this period of near-equilibrium is the upper gravel. Overall, the upper gravel is coarser than the middle gravel, indicating that the river is flushing sand downstream and leaving behind a pebble lag.

Each phase of formation of the modern valley-latest Pleistocene valley cutting, Pleistocene-Holocene aggradation, and Holocene equilibrium - probably moved upstream from its point of initiation. In the South Platte, the coarse basal gravel that represents the end of incision can be traced from the vicinity of Fort Lupton upstream to section $S$ - $S^{\prime}$ south of Denver. The record of downstream aggradation (middle 

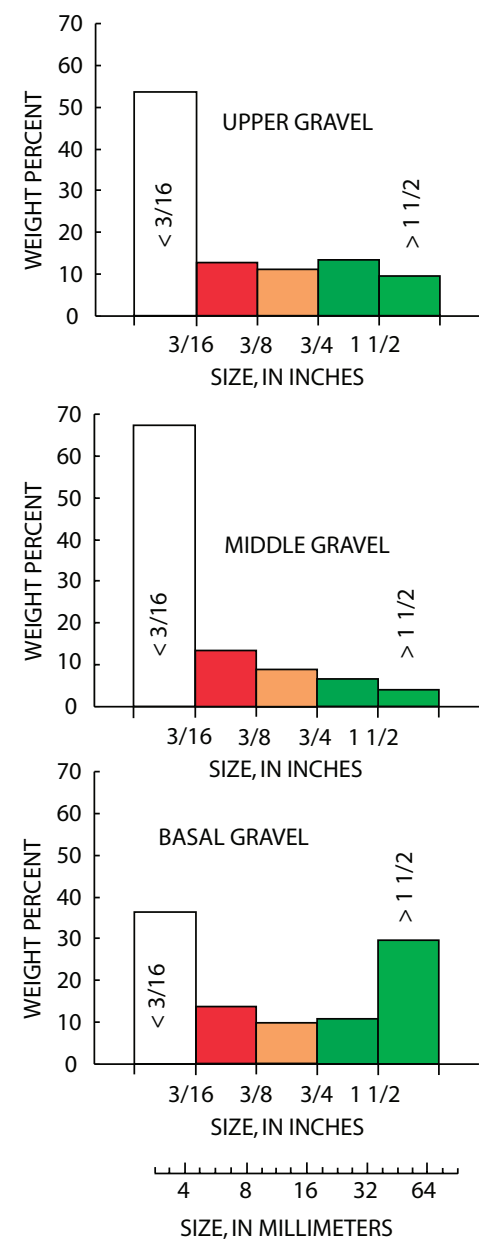

Figure 5. Histograms showing particle size in three gravel units of modern valley, South Platte River (Lindsey, Langer, and Shary, 1998). Samples from North Dahlia, Howe, and Mann Lake gravel pits (fig. 3); pits near sections $M-M^{\prime}, N-N^{\prime}$, and $0-O^{\prime}$ (fig. 2). For upper unit, particle size determined from 9 sieve analyses; for middle unit, 9; for basal unit, 6 analyses.

gravel) does not appear upstream from section $Q-Q^{\prime}$ (fig. 4). The record of equilibrium and lateral cutting (upper gravel) is present from the vicinity of Fort Lupton to south of Denver.

\section{Cache la Poudre River Valley}

Sections compiled from borehole logs (fig. 6) show the alluvial stratigraphy of the Cache la Poudre River valley. The valley has extensive flanking terraces at two or more levels, 5 to $15 \mathrm{~m}$ above the surface of the modern valley. Correlation of terraces is from mapping by Colton (1978) and Swan (1975); Swan (1975) also described soil profiles. The highest terrace, about $15 \mathrm{~m}$ above the modern valley surface at Fort Collins, is composed of silt and clay mapped as Slocum Alluvium (fig. 6, section $C$ - $C^{\prime}$ ). About $8 \mathrm{~km}$ downstream, at section $D$ $D^{\prime}$, remnants of both Slocum and Verdos Alluvium cap hills overlooking the north side of the river valley. On the south side of the valley west of Greeley, at $F-F^{\prime}$, a terrace at $15 \mathrm{~m}$ above the modern valley is mapped as Louviers Alluvium (Colton, 1978). The terrace northeast of Greeley (fig. 6, section $G-G^{\prime}$ ), covered by eolian deposits as mapped by Colton (1978), lies at the same level as the Louviers. Downstream from Fort Collins, at sections $C$ - $C^{\prime}$ through $E-E^{\prime}$, an extensive terrace about $5 \mathrm{~m}$ above the modern valley on the north side of the river is correlated with Broadway Alluvium (Colton, 1978). At Greeley, a terrace between the Cache la Poudre and South Platte Rivers, about $5 \mathrm{~m}$ above the modern valley surface, lies at the same level as the corresponding terrace of Broadway Alluvium south of the South Platte (fig. 6, section $G$ - $G^{\prime}$, and fig. 4, section $\left.G-G^{\prime \prime}\right)$. The latter terrace extends continuously south to Denver. A low terrace, found locally along the Cache la Poudre but not intersected by the sections, may be equivalent to low terraces mapped as Piney Creek along the South Platte River south of Greeley (Colton, 1978). Holocene post-Piney Creek and older alluvium underlies the modern valley of the Cache la Poudre.

Fill terraces mapped as Broadway Alluvium form the largest continuous surfaces; most are located north of the river, but, locally, they are present south of the river. The treads of the terraces slope toward the river, more steeply in some sections than in others, possibly owing to addition of deposits from tributary valleys. Both the Broadway and Louviers Alluvium contain coarse cobble and pebble gravel interleaved with lenses of sand, silt, and clay. An extremely poorly sorted mixture of silt, sand, and gravel (called "dirty gravel") is interleaved with sorted gravel (fig. 6, sections $A-A^{\prime}$ and $B-B^{\prime}$ ). The alluvial fill beneath the Broadway terrace reaches 15 $\mathrm{m}$ thick (fig. 6, sections $B-B^{\prime}$ and $C-C^{\prime}$ ). Downstream near Greeley, terraces of Louviers Alluvium flank both sides of the valley and alluvial fill reaches $30 \mathrm{~m}$ in thickness (sections $F-F^{\prime}$ and $G$ - $G^{\prime}$ ). The thickest deposits beneath both terraces overlie channels in bedrock.

During deposition of the alluvium mapped as Louviers, the Cache la Poudre River appears to have flowed down the south side of the valley west of Greeley, then crossed to the north side of the valley east of Greeley. During deposition of the Broadway terrace fill, the channel of the Cache la Poudre occupied the northern part of the valley east of Fort Collins. During or after deposition of Broadway Alluvium, the course shifted south, cutting and then partially filling the modern valley. The southward shift of the course of the river was probably a response to major contributions of sediment from tributaries on the north side of the valley. Almost all tributaries (not shown on fig. 2) between Fort Collins and Greeley enter the Cache la Poudre River from the north. At many sections, the present course of the river lies near the middle or northern side of the modern valley, indicating that the river has shifted back to the north, eroding older alluvium in some of the terraces. Only section $E-E^{\prime}$ shows the river undercutting the south side of the valley at present.

A distinctive characteristic of the Louviers and Broadway terrace fill of the Cache la Poudre River valley is the presence 

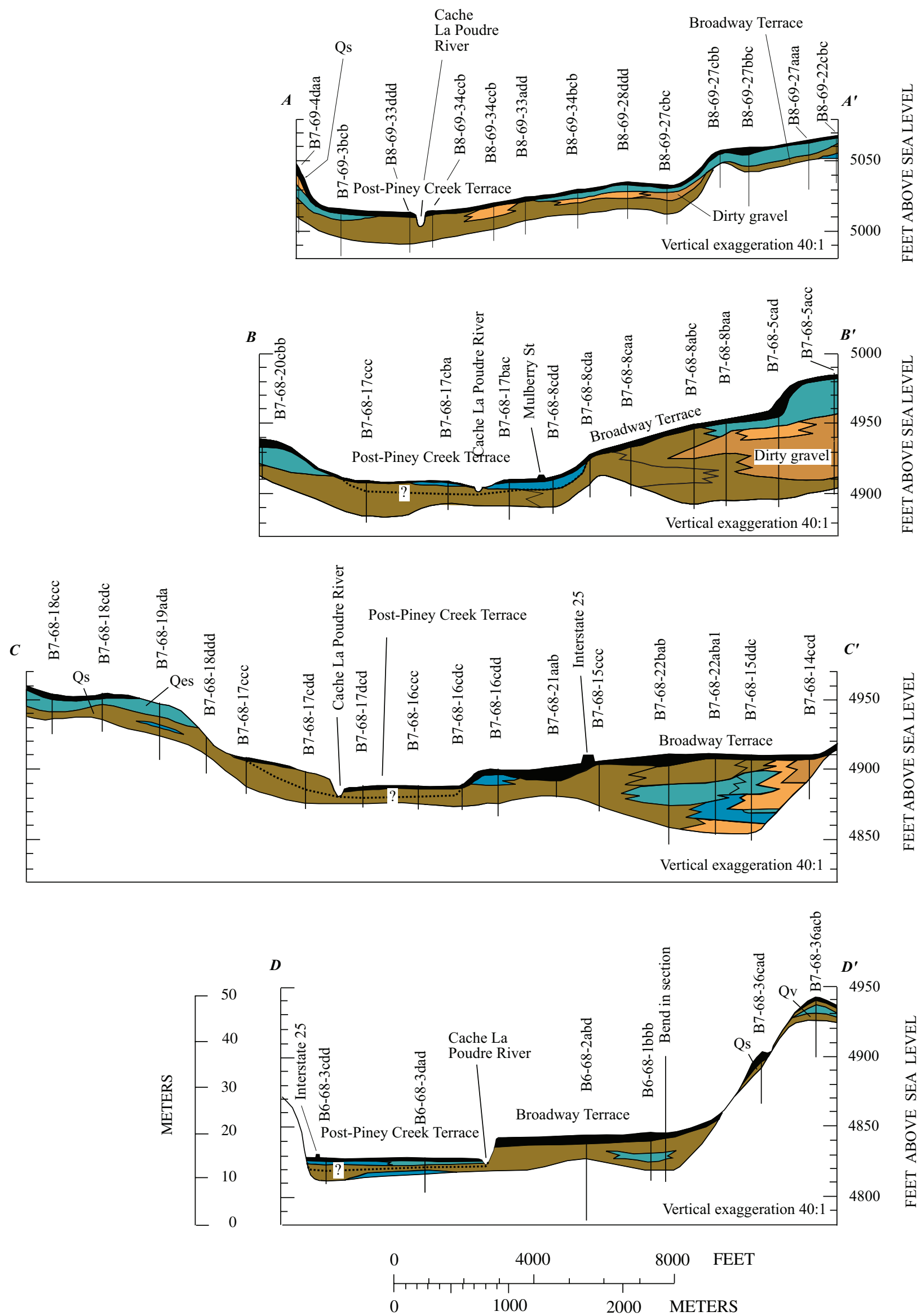
Figure 6 (facing page and

right). Sections through alluvial fill of the Cache la Poudre River valley from Fort Collins to Greeley, Colo. (Langer and Lindsey, 1999), based on borehole logs by Schneider and Hershey (1961). Terrace identifications from Colton (1978). Qv, Verdos Alluvium; 0s, Slocum Alluvium; Qes, eolian sand, silt, and clay.
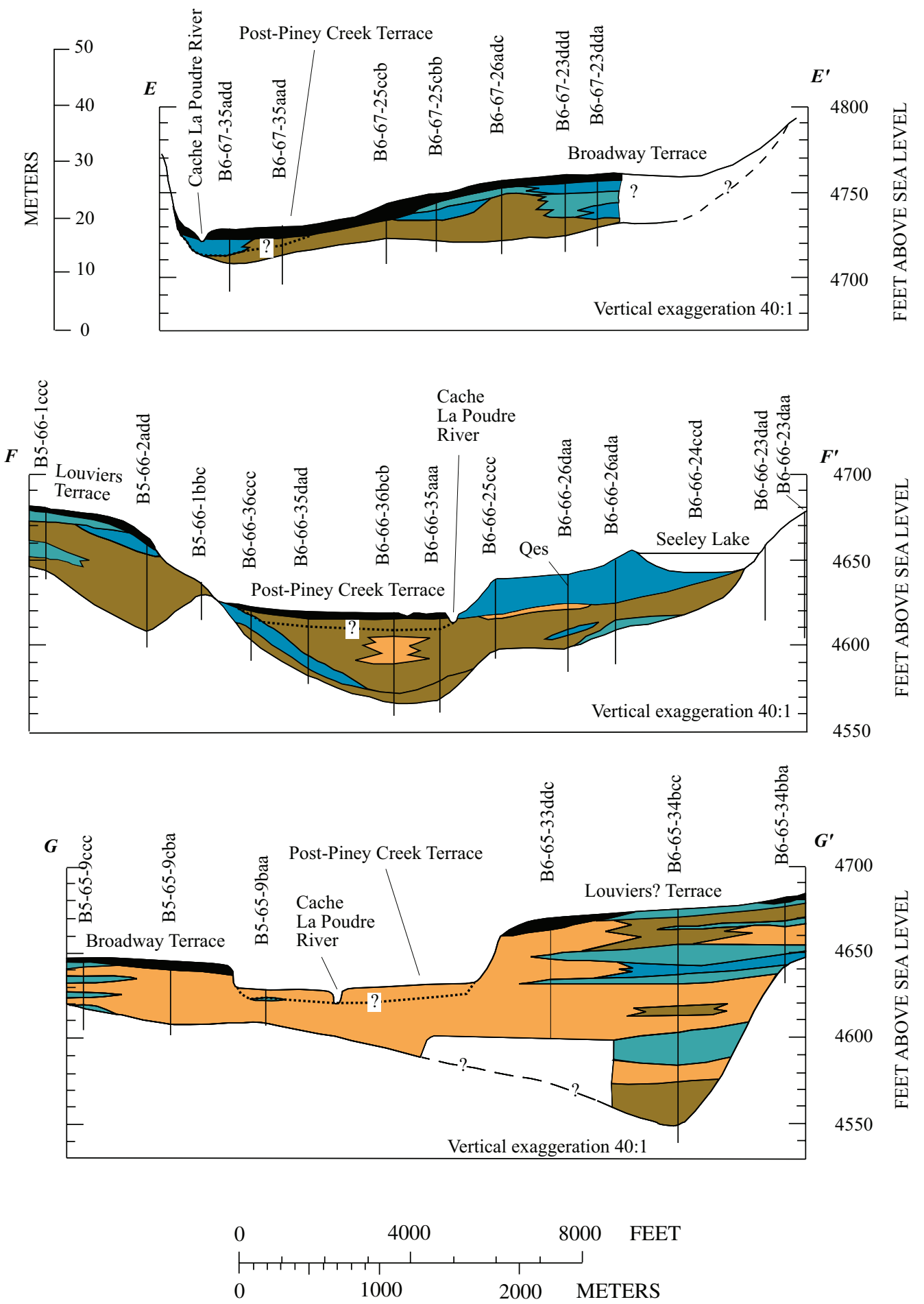

EXPLANATION

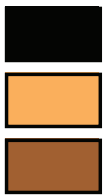

Soil and overbank silt

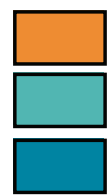

Dirty gravel

Sand $>$ gravel

Silt and

Gravel > sand

Sand 
of laterally extensive deposits of sand, silt, and clay, some of which may be of eolian origin (fig. 6). These deposits mantle the Broadway (sections $A-A^{\prime}, B-B^{\prime}$, and $E-E^{\prime}$ ) and Louviers (sections $F-F^{\prime}$ and $G-G^{\prime}$ ) terraces and extend onto uplands having relict dune and deflation topography (shown on map by Colton, 1978). In addition, sand, silt, and clay lenses occur within the terrace fill at some sections (fig. 6). These finegrained deposits on and within the Louviers and Broadway Alluvium of the Cache la Poudre River valley are comparable to, but are not as extensive as, those of the Broadway Alluvium in the South Platte River valley (fig. 4).

Alluvium at the surface of the modern valley of the Cache la Poudre River is mapped as Holocene post-Piney Creek (Colton, 1978). The uppermost part of the Holocene alluvium consists of 1-1.5 m of laminated overbank deposits of gray and brownish-gray (Munsell colors) silt, clay, and very fine sand. The contact between overbank deposits and coarse gravel is commonly sharp.

Two gravel units (fig. 7) can be distinguished in gravel pits in the modern valley of the Cache la Poudre River (Langer and Lindsey, 1999), but they are not distinctive enough to identify in the borehole logs used to compile the sections of figure 6 . The gravel units are not everywhere distinguishable, and their appearance is not consistent from one locality to the next. They could not be distinguished in pits upstream from Fort Collins, where the gravel is very coarse, but they are visible in gravel pits near most other sections. The contact between the two units is marked by changes in texture and Munsell color. The lower unit, commonly about $1.5-2.5 \mathrm{~m}$ in thickness, is slightly coarser grained (fig. 8) and, in some places, more massive than the upper unit. The lower unit varies in color through shades of grayish brown, brown, and yellowish brown, and, overall, it has a more oxidized appearance than the upper unit (Langer and Lindsey, 1999). The upper unit, $1-5 \mathrm{~m}$ in thickness, is light gray to brown and in some places contains lenses of sand, silt, and clay and irregular intraclasts of silt, ranging from about $3 \mathrm{~cm}$ to $1 \mathrm{~m}$ across. The contact with the lower unit is an irregular erosional surface; in some places, lenses and intraclasts of organic-rich silt rest on the contact. These organic-rich lenses and intraclasts are interpreted as part of a layer of overbank sediment that once overlay the lower unit but was eroded and redeposited in the upper unit. The upper gravel unit is interpreted to be Holocene, the result of lateral cutting and filling by the river channel as it migrates across the valley. The lower gravel unit may be late Pleistocene (Broadway) in age.

Swan (1975) thought that Holocene (post-Piney Creek) alluvium occupies only the uppermost part of the alluvial fill beneath the modern valley. Based on oxidation, he (Swan, 1975) assigned the remainder of the gravel, probably including the entire lower unit, to late Wisconsin (Broadway) age. He attributed oxidation of gravel to weathering during formation of a late Wisconsin soil, now eroded. Although we concur with Swan's (1975) age assignments, our measurements in gravel pits (Langer and Lindsey, 1999) show that the weakly oxidized upper gravel accounts for as much as half (and in some places more) of the total thickness of alluvium.

Two gravel units, comparable to those of the Cache la Poudre valley, have also been described in the valley of St. Vrain Creek (Madole, 1976). The two St. Vrain gravel units

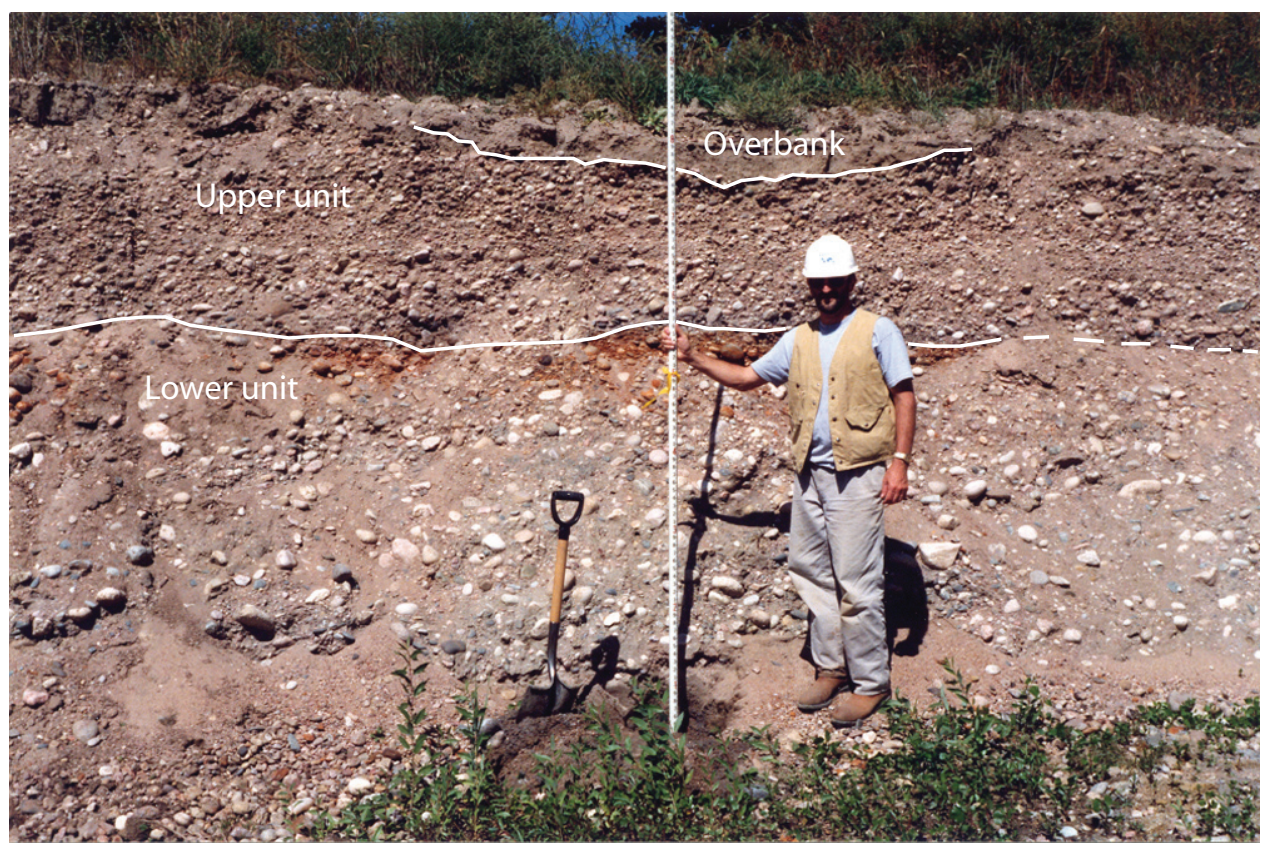

Figure 7. Photograph showing differences in color, texture and particle size between two gravel units beneath the flood plain of the Cache la Poudre River, POE pit (from Langer and Lindsey, 1999). 

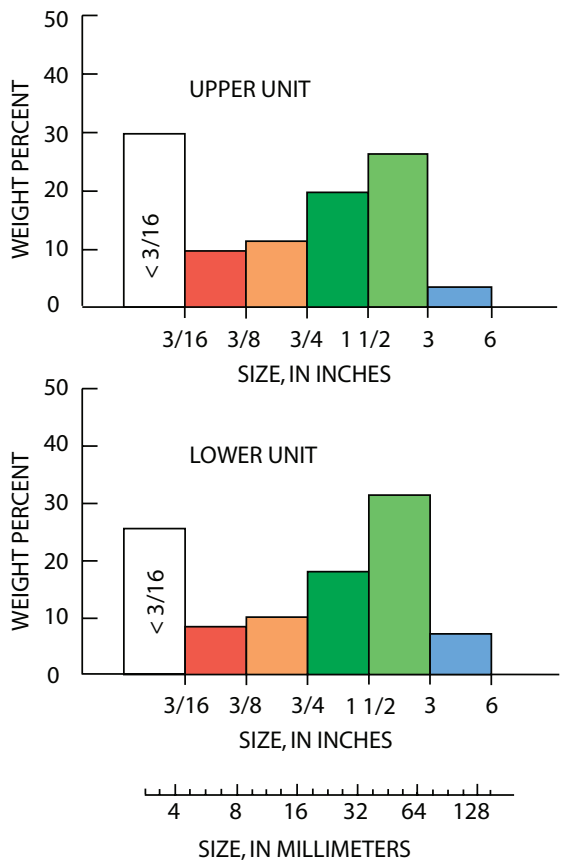

Figure 8. Histograms showing particle size in upper and lower gravel units of modern valley, Cache la Poudre River (calculated from data of Langer and Lindsey, 1999). For upper unit, particle size determined from 13 sieve analyses; lower unit, from 15 sieve analyses. Samples from gravel pits POE near Fort Collins downstream to 25th Street (GW) at Greeley (fig. 3); near sections $B-B^{\prime}$ through $F-F^{\prime}$ (fig. 2).

are separated by a discontinuous, organic-rich zone of sediment that has been dated as Holocene by the radiocarbon method (Madole, 1976). Madole (1976) assigned a Holocene age to the upper St. Vrain gravel and correlated the lower (undated) gravel with Broadway Alluvium. In both the St. Vrain and Cache la Poudre valleys, however, no reliable age has been established for the lower gravel.

The shallowness of incision of the Cache la Poudre valley prior to deposition of the lower gravel unit stands in contrast to cross sections of the South Platte River at Denver, as does the overall similarity in grain size between the lower and upper gravel units. The lower unit is only slightly coarser than the upper (fig. 8) (Langer and Lindsey, 1999). The similarity in particle size of units indicates that stream power of the Holocene Cache la Poudre River has declined very little since it deposited the lower unit. On some sections (fig. 6), the base of the lower unit is seen to be slightly incised below the base of the adjacent Broadway terrace fill. Both rest on bedrock (Pierre Shale near Fort Collins, younger formations closer to Greeley). Incision of the Broadway terrace of the Cache la Poudre River during latest Pleistocene time appears to have been shallower than incision of the Broadway terrace of the South Platte River. Unlike the South Platte, no record of increased sediment production during incision has been recognized in the Cache la Poudre River valley. After initial incision and deposition of bedload, the Cache la Poudre reached near- equilibrium, manifested by lateral cutting and deposition of the upper unit.

\section{Other Tributary Valleys}

Sections through the alluvial fill of Lefthand, Boulder, Ralston, Clear and Bear Creeks-prepared from geologic maps, field observations, and borehole logs-show a variety of stratigraphic features. No logs were found for alluvial fill of St. Vrain Creek and the Big and Little Thompson Rivers. Three sections through the alluvial fill of the Big Thompson River valley, constructed by S-wave seismic refraction methods, revealed one or, in some places, two gravel units (Barnett and Ellefsen, 2000). The maximum total thickness reported for alluvial fill in the Big Thompson River valley is $13 \mathrm{~m}$. Two gravel units have also been recognized in the alluvial fill of St. Vrain Creek. An upper gravel, 0.5-1.5 m thick in most places and at least $0.5 \mathrm{~km}$ wide, is dated at 3,900-1,900 radiocarbon years (Madole, 1976). A lower gravel, 2-6 $\mathrm{m}$ in thickness and $1.1-1.5 \mathrm{~km}$ in width, is correlated with Broadway Alluvium (Madole, 1976).

\section{Lefthand Creek}

A section (fig. 9, $U-U^{\prime}$ ) through the valley of Lefthand Creek near Niwot, northeast of Boulder, is based on a line of closely spaced boreholes. At the line of section, Lefthand Creek is not deeply incised and is bordered by low terraces of Louviers Alluvium that extend about $1.5 \mathrm{~km}$ across the valley (Trimble, 1975). As mapped by Trimble (1975), eolian sand and silt border the southeast side of the terrace. The terrace fill rests on Upper Cretaceous Pierre Shale. The stratigraphy of the terrace fill follows a simple fining-upward sequence typical of alluvial deposits. Boreholes show 1.5-3 m of sandy gravel with cobbles in the lower part, lenses of sand as much as $6 \mathrm{~m}$ thick in the middle part, and about $2 \mathrm{~m}$ of silt and clay at many sites in the upper part (Jenkins, 1961). This sequence can be interpreted as a single sequence of valley-cutting followed by aggradation and equilibrium. At the line of section, a slight depression at the base of the gravel on the northern side of the valley suggests that the stream channel started there, migrated south, and then reoccupied the northerly site during Holocene time. The origin of the upper silt and clay layer is unclear; it may be alluvial, eolian, pedogenic, or some combination.

Exposures near the line of section on Lefthand Creek are few. About $0.8 \mathrm{~km}$ west of the line of section and $0.4 \mathrm{~km}$ south of Lefthand Creek, gravel from a small, freshly dug but flooded pit was examined. In the pit, about $1 \mathrm{~m}$ of silt and sand overlies gravel that might represent the lower unit of the section. Piles of excavated yellowish-brown sand and gravel contained abundant rounded pebbles of granite, pegmatite, gneiss, sandstone, and volcanic rock. Many of the pebbles were coated with calcium carbonate. 

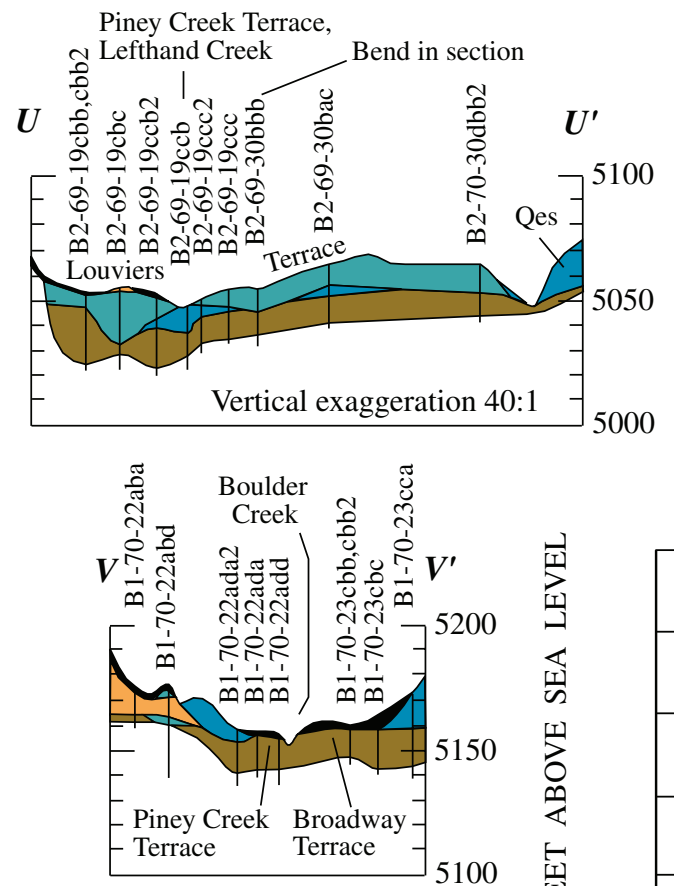

Vertical exaggeration 40:1

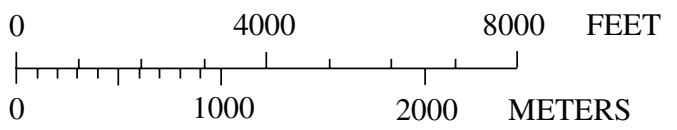

\section{EXPLANATION}

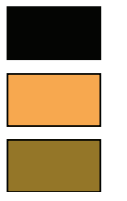

Soil, colluvium, overbank silt, and artificial fill Sand $>$ gravel

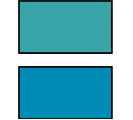

Silt and clay

Gravel > sand

Sand

Figure 9. Sections through alluvial fill of the valleys of Lefthand $\left(U-U^{\prime}\right)$ and Boulder (V-V) Creeks, based on borehole logs reported by Jenkins (1961) and geologic map by Trimble (1975). Qes, eolian sand, silt, and clay.

\section{Boulder Creek}

The section across the valley of Boulder Creek (fig. 9, $\left.V-V^{\prime}\right)$ does not extend far up the sides of the valley wall and thus does not show relationships with older alluvial terraces. South of the line of section, the wall of the valley at Valmont Reservoir is held up by an igneous dike or sill (Trimble, 1975). The fill itself consists largely of coarse pebble and cobble gravel beneath the tread of the Broadway terrace. Immediately north of the modern channel, sediment at the surface is assigned to the Piney Creek Alluvium (Trimble, 1975). Toward the valley sides, the coarse gravel fill is overlain by sand. Although the section broadly resembles a fining-upward alluvial sequence, the sequence is apparently not the result of a single aggradation event. As mapped by Trimble (1975), the gravel fill is probably late Pleistocene Broadway Alluvium and the overlying sand is Holocene Piney Creek Alluvium.

\section{Ralston Creek}

The valley of Ralston Creek does not contain much alluvial fill, except at its lower end, where gravel of the Louviers Alluvium of Clear Creek crosses the drainage divide and has been reworked by Ralston Creek. At Wadsworth Boulevard in Arvada, two boreholes in the modern valley of Ralston Creek encountered 5-6 m of mostly sand; within the sand, the holes encountered only $0.15-0.75 \mathrm{~m}$ of gravel (McConaghy and others, 1964; Lindvall, 1979b). No section was drawn through these two boreholes.

From the viewpoint of Pleistocene alluvial history, the most interesting part of Ralston Creek valley lies upstream from Arvada, at sections $W-W^{\prime}$ and $W^{\prime \prime}-W^{\prime \prime \prime}$ (located on fig. 2). There, terraces of Broadway, Louviers, and Slocum Alluvium border the south side of Ralston Creek, and Verdos Alluvium borders the north side (Baker, 1973, 1974; Van Horn, 1976, see his fig. 21). At the highest levels, Rocky Flats Alluvium caps a ridge south of the creek and forms the high plain north of the creek. Although no borehole logs are available, ditch and road cuts in all terraces reveal thin fills and lags of gravel (fig. 10). The Verdos Alluvium is well exposed in gravel pits on the terrace north of Ralston Creek. From observations in these exposures, as well as the geologic map of the Golden quadrangle (Van Horn, 1972) and section $A-A^{\prime}$ of Baker (1973, 1974), sections were constructed to show the relationships among the various terraces (fig. 10). The main section $\left(W-W^{\prime}\right)$ follows a prominent high-voltage electric line, located on the Golden quadrangle map. A supplementary section, $W^{\prime \prime}-W^{\prime \prime \prime}$, located about $1.6 \mathrm{~km}$ upstream, was constructed to better show the relationships among terraces on the south side of Ralston Creek.

At the lines of sections (fig. 10), Ralston Creek has cut a narrow valley containing distinct unpaired terraces. From bottom up, these terraces consist of Piney Creek Alluvium (the valley floor), Broadway Alluvium (about $4 \mathrm{~m}$ above the Piney Creek Alluvium), and Louviers Alluvium (about $15 \mathrm{~m}$ above the Piney Creek) (Baker, 1973, 1974). Each terrace is covered by a thin $(<2 \mathrm{~m})$ lag of sand and gravel. A lag deposit of coarse cobbles and boulders occurs on the surface of the Louviers terrace. The Slocum terrace is about $30 \mathrm{~m}$ above the Piney Creek Alluvium and forms broad plains of very thin (< $0.3 \mathrm{~m}$ ) alluvium. In some places, the Slocum is dissected and slopes down almost to the level of the Louviers terrace. North of Ralston Creek, a steep-walled mesa-a terrace remnant of Verdos Alluvium - stands about $75 \mathrm{~m}$ above the Piney Creek Alluvium. In gravel pits of the Pioneer Sand Co., 1-6 $\mathrm{m}$ of coarse gravel rests on clay and siltstone of the Upper Cretaceous Arapahoe Formation. In another pit about $2.4 \mathrm{~km}$ west of the Pioneer pits, Van Horn (1976) reported a small lenticular bed of silt containing reworked volcanic ash about 3 $\mathrm{m}$ below the top of mixed Verdos Alluvium and old fan allu- 

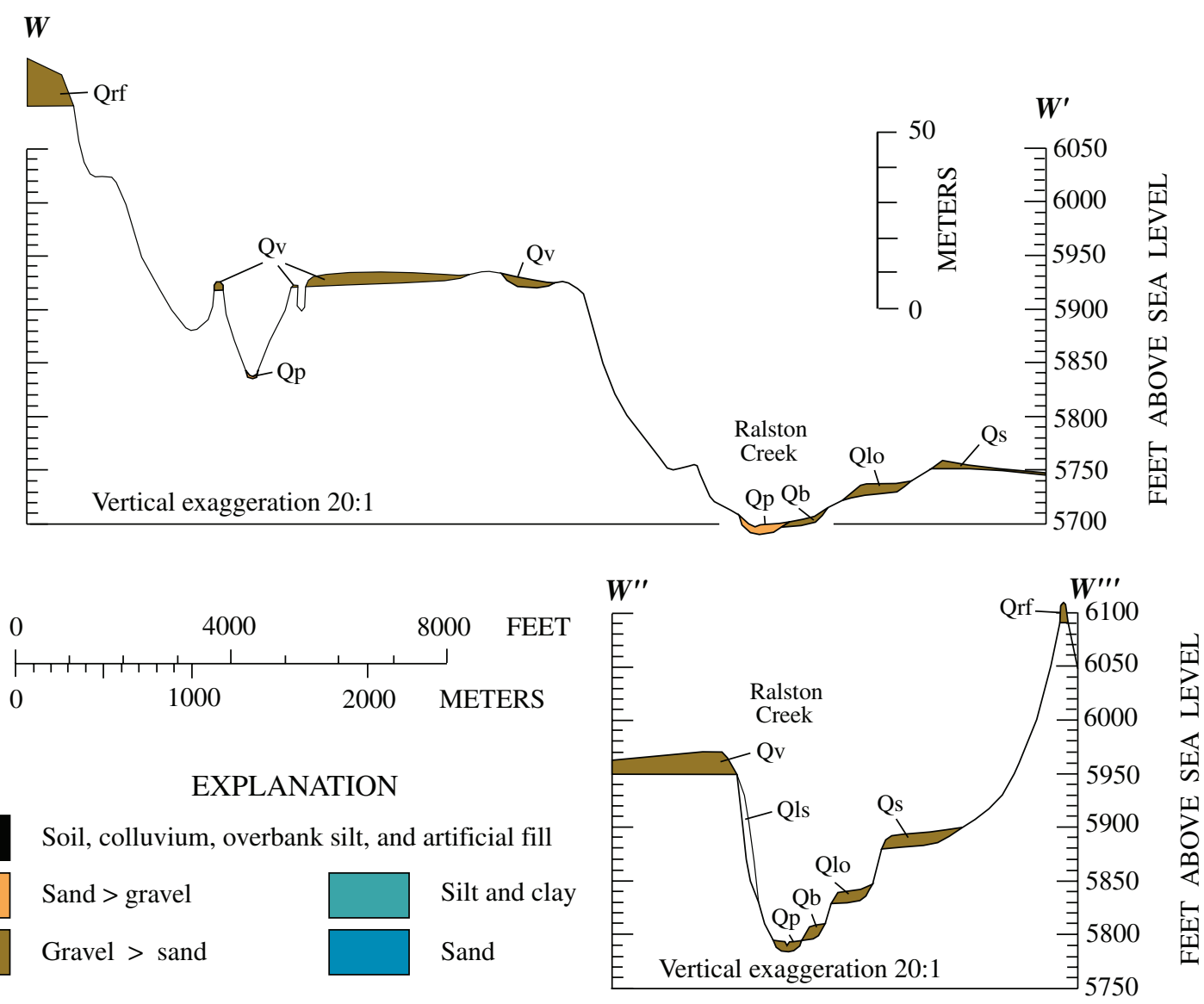

Figure 10. Sections through alluvial fill of the valley of Ralston Creek near the foothills, based on examination of gravel pits, road cuts, and irrigation ditches, and the geologic map by Van Horn (1972). Supplementary section $W^{\prime \prime}-W^{\prime \prime \prime}$ approximately follows the line of Baker's $(1973,1974)$ section $A-A^{\prime}$; it is located about $1.5 \mathrm{~km}$ upstream from section W-W'. Orf, Rocky Flats Alluvium; Qv, Verdos Alluvium; Qs, Slocum Alluvium; Qlo, Louviers Alluvium; Qb, Broadway Alluvium; Qp, Piney Creek Alluvium; Qls, landslides. Except for Verdos Alluvium, which is exposed in pits on north side of Ralston Creek, thicknesses of alluvium are estimated from map. Colluvium and soil not shown.

vium. Exposures of the ash and alluvium are poor; thus, the stratigraphic relationship of the ash to the Verdos is uncertain (Birkeland and others, 1996). The volcanic ash at this locality has been correlated with the Lava Creek B ash (Izett and Wilcox, 1982), estimated to be $\sim 640 \mathrm{ka}$ in age (Lanphere and others, 2002).

The base of the Verdos gravel is sufficiently exposed in the Pioneer pits to discern a gently undulating surface with as much as $3 \mathrm{~m}$ of local relief cut on the Arapahoe Formation. Near the southern border of the mesa, a channel fill in Verdos Alluvium has been excavated for gravel. The east-northeast trend and nearly $300 \mathrm{~m}$ width of the channel is clear on aerial photographs (fig. 11). Approximately 3-6 m of gravel filled the channel. Test pits on the south side of the channel, immediately north of the southern scarp of the Verdos terrace, expose less than $1 \mathrm{~m}$ of gravel on bedrock. The north wall of the channel is clearly exposed in a cut made to mine clay from the underlying Arapahoe Formation. The width of the excavated channel is probably not indicative of channel cross section at any one time, but instead records the result of multiple channel positions as the stream cut laterally into bedrock. Nor does the excavated feature represent a paleovalley because the Verdos terrace that represents a part of the paleovalley is much wider than the excavation (fig. 11).

From the section, it can be seen that the Verdos Alluvium north of Ralston Creek covered a valley floor that was cut more than $50 \mathrm{~m}$ into the Rocky Flats Alluvium (fig. 10). Baker (1974) thought that the Verdos Alluvium here might have been deposited after a low-gradient stream in the Denver Basin captured the Verdos stream. He (Baker, 1974) pointed out that the top of the Verdos Alluvium north of Ralston Creek slopes northeasterly, whereas all of the younger terraces slope southeasterly, parallel to the course of Ralston Creek. Although the divergence of slope direction is about $40^{\circ}$ at the line of section, all of the terraces including the Verdos turn due east as they follow the course of Ralston Creek downstream. Given the downstream variation in the course of Ralston Creek, we do not attribute any significance to local divergences in direction of terrace slopes here. Baker (1974) also wrote that the Verdos 


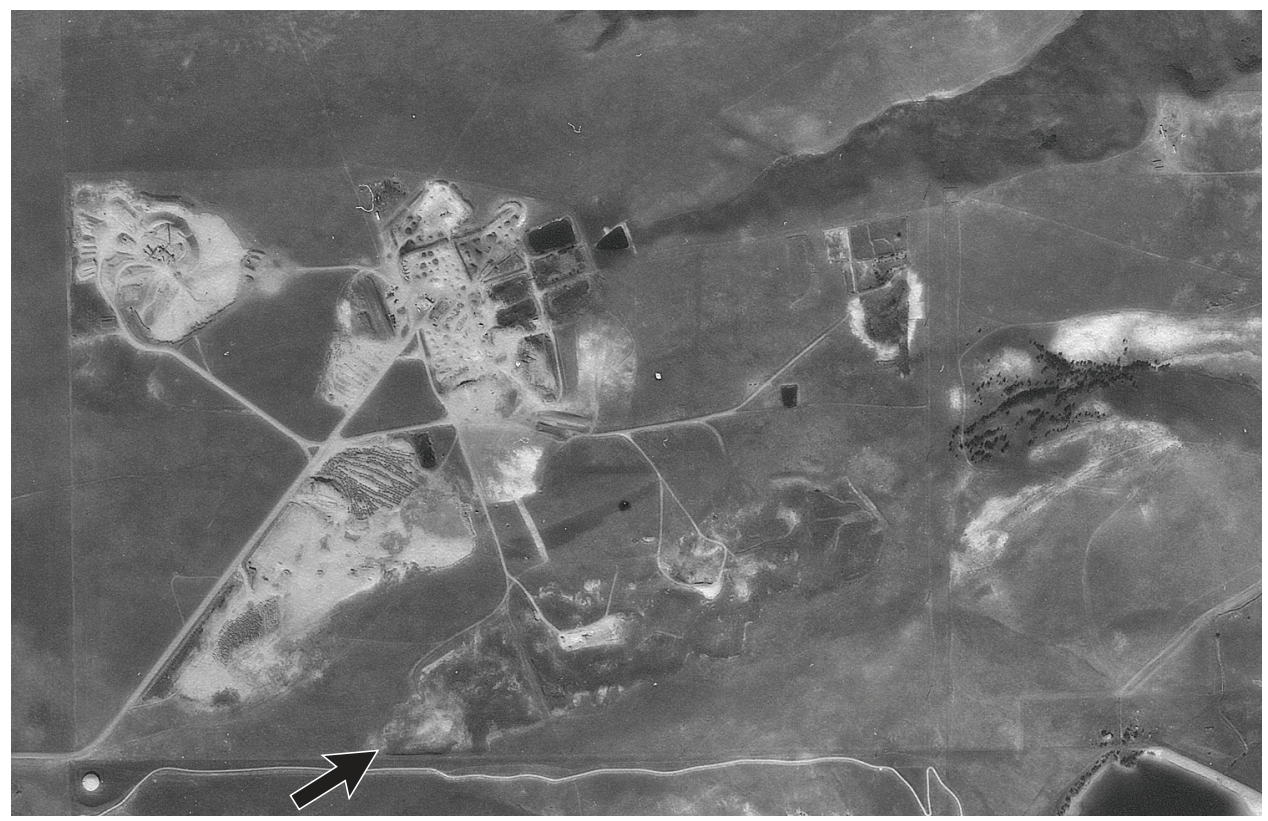

Figure 11. Aerial photograph showing paleochannel excavated for gravel (arrow-trends from lower center left to right center; area of photograph about $2.5 \mathrm{~km}$ across). Verdos Alluvium in Pioneer gravel pits, field locality 44, figure 3, Ralston Creek. USGS photography, October 4, 1999.

gravel was coarser than that of younger terrace gravel, but we found cobbles and boulders in Louviers gravel at the line of section. We interpret the Verdos Alluvium here as a remnant of the Pleistocene course of Ralston Creek.

\section{Clear Creek}

Two sections across Clear Creek were prepared from borehole logs, and a third section was prepared from the geologic map of Van Horn (1972), section $B$ - $B^{\prime}$ of Baker (1973, 1974), and borehole depths to bedrock off the line of section nearby (fig. 12). The downstream section $\left(X-X^{\prime}\right)$ is located 2.7 $\mathrm{km}$ below the confluence of Clear Creek and Ralston Creek; the middle section $\left(Y-Y^{\prime}\right)$ is $3.7 \mathrm{~km}$ above the confluence; and the upstream section $\left(Z-Z^{\prime}\right)$ is $5.6 \mathrm{~km}$ above the confluence. The upstream section follows an aqueduct line shown on the Golden $712^{\prime}$ quadrangle map.

A prominent terrace overlooks the modern valley of Clear Creek. Downstream from a point between the middle $\left(Y-Y^{\prime}\right)$ and upstream $\left(Z-Z^{\prime}\right)$ sections, the terrace has been mapped as Slocum Alluvium on the south side of the valley (Lindvall, 1979a, 1979b). However, upstream from the confluence of Ralston Creek the terrace has been mapped as Louviers Alluvium on the north side of the valley (Lindvall, 1979b; Van Horn, 1972). At the upstream section $\left(Z-Z^{\prime}\right)$, Louviers Alluvium has been mapped on both sides of Clear Creek valley (Van Horn, 1972). At all locations, the treads of both the Slocum of Lindvall (1979b) and the Louviers of Lindvall (1979b) and Van Horn (1972) lie about 12-15 m above the modern valley surface. Where exposed or drilled, the base of the terrace fill lies about $6 \mathrm{~m}$, or slightly less, above the modern valley surface. Based on examination of exposures near the downstream section $\left(X-X^{\prime}\right)$ and topographic relationships measured in the sections, we suggest that Lindvall's (1979b) Slocum may be Louviers.

The elevations of the top and bottom of the Louviers Alluvium are clear at section $Z-Z^{\prime}$. On both sides of the valley, the top of the Louviers is about $15 \mathrm{~m}$ above the modern valley. Colluvium along the north wall of the valley obscures the base of the Louviers. However, in a small gravel pit southeast of 44th Avenue and McIntyre Street (field locality 72, fig. 3), the base of the Louviers can be inferred to coincide with the bottom of the pit where springs emerge from the gravel. At locality 72, the Louviers age of the terrace fill was confirmed by studies of the soil profile (Baker, 1973; Machette and others, 1976). On the south side of Clear Creek, the base of the Louviers, marked by small exposures of Denver Formation, is about $6 \mathrm{~m}$ above the south side of the modern valley (Van Horn, 1972). These relationships indicate that modern valley fill lies below all of the Louviers terrace fill and therefore must be younger than the terrace.

In the downstream section $\left(X-X^{\prime}\right)$, the flanking terraces show the same topographic relationships as those upstream, at section $Z-Z^{\prime}$. On both sides of the valley, about $6 \mathrm{~m}$ of coarse gravel overlies bedrock of Denver Formation at about $6 \mathrm{~m}$ above the modern valley. On both sides of the valley, the top of the gravel lies about $12 \mathrm{~m}$ above the modern valley. The 

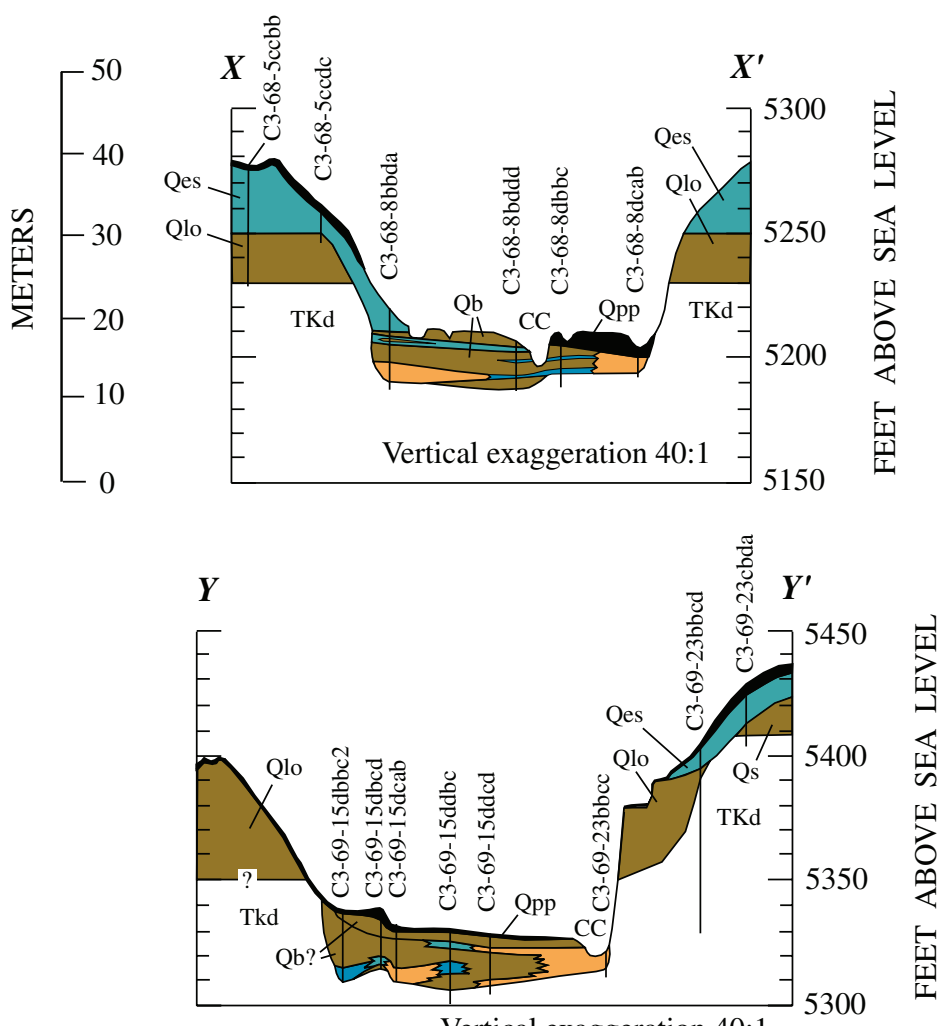

$Z$

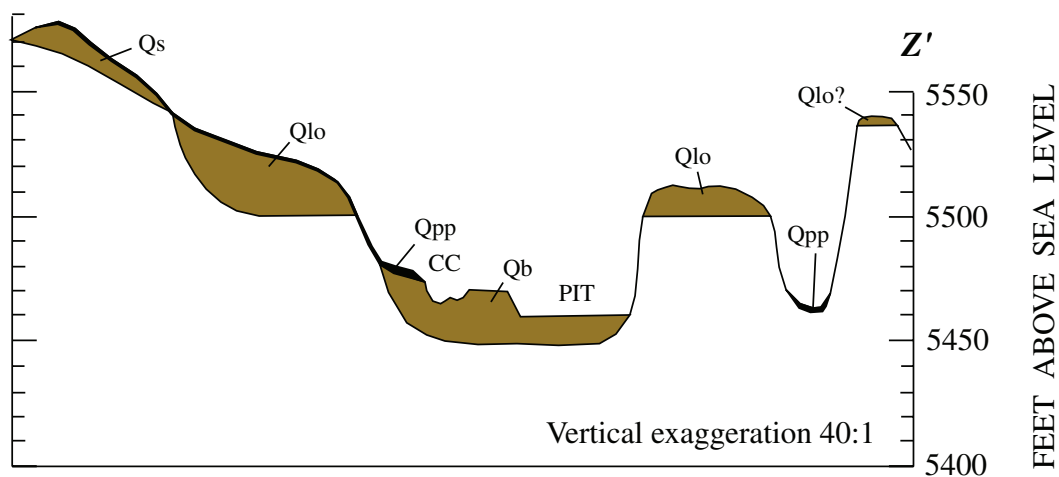

\section{EXPLANATION}

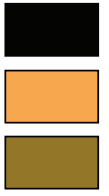

Soil, colluvium, overbank silt, and artificial fill

Sand $>$ gravel

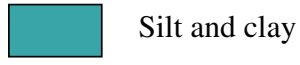

Gravel > sand
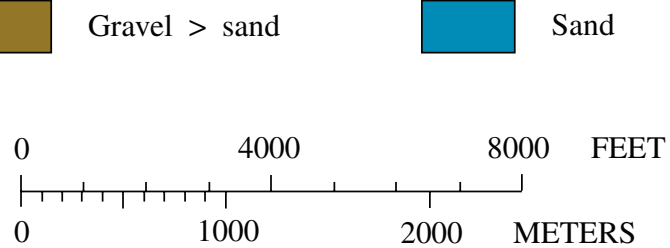

Figure 12. Sections through alluvial fill of the valley of Clear Creek, based on borehole logs reported by McConaghy and others (1964) and geologic maps of Lindvall (1979b) and Van Horn (1972). $X-X^{\prime}$, downstream near Federal Boulevard; $Y-Y^{\prime}$, between Kipling Street and Wadsworth Boulevard; and $Z-Z^{\prime}$, approximately follows Baker's $(1973,1974)$ section $B$ - $B^{\prime}$ along an aqueduct upstream from Youngfield Avenue. Qpp, post-Piney Creek Alluvium; Qb, Broadway Alluvium; Olo, Louviers Alluvium; Os, Slocum Alluvium; Qes, eolian deposits of silt and clay (loess). Queries (?) where base of gravel uncertain owing to concealment. CC, channel of Clear Creek. 
former terrace tread is covered by fine sand and silt identified as eolian (Lindvall, 1979b). Inspection of the terrace gravel on the south side of the creek reveals moderate weathering of clasts and rinds of calcium carbonate consistent with Louviers Alluvium. However, no well-exposed soil profile was found for study. Lindvall (1979b) reports a "strongly developed calcium carbonate-enriched zone" on the terrace gravel, which he (Lindvall, 1979b) correlated with Slocum Alluvium.

Most of the gravel fill of the modern valley is here correlated with the Broadway Alluvium (Baker, 1973, 1974). Lindvall (1979b) and Van Horn (1972) both mapped Louviers Alluvium beneath post-Piney Creek Alluvium in gravel pits and sections. However, studies of soil profiles and weathering of gravel beneath the modern valley surface (Baker, 1973) demonstrate that clasts are less weathered and coatings of calcium carbonate on clasts are much thinner than in Louviers Alluvium on the flanking terraces. Near section $Z-Z^{\prime}$, we observed a thin $(<1 \mathrm{~m})$ overbank deposit of unweathered stratified silt covering Broadway gravel. This overbank silt is the post-Piney Creek Alluvium of Lindvall (1979b) and Van Horn (1972), formed when Clear Creek overflows its banks. Downstream at section $X-X^{\prime}$, as much as $3 \mathrm{~m}$ of unconsolidated sandy silt of probable post-Piney Creek age was observed in creek banks.

In sections $X-X^{\prime}$ and $Y-Y^{\prime}$, drawn from borehole logs, the valley fill is dominated by coarse (pebble and cobble) gravel. Both sections reveal a tendency for sandy sediment to dominate the basal and southern parts of the fill. Above the sandy base, sandy lenses separate 3-6 $\mathrm{m}$ of gravel from a thin $(1.5 \mathrm{~m})$ upper gravel. Approximately the same stratigraphic sequence is evident in both the middle and downstream sections, which are located about $6.5 \mathrm{~km}$ apart. Where exposed along the creek banks, the upper gravel is very coarse; cobbles are abundant.

Although the present stream tends to hug the south wall of the valley throughout much of its course, the stream must have occupied the middle and north sides of the valley for much of its history. The alluvial fill is dominated by sand along the south side of the valley and gravel in the middle and northern sides (fig. 12). Also, the deepest and thickest fill lies near the section midpoints. In sections $X-X^{\prime}$ and $Y-Y^{\prime}$, the surface of the modern valley, and the post-Piney Creek Alluvium, tend to slope south, toward the present location of the channel in section $Y-Y^{\prime}$. From these relationships, we infer that the post-Piney Creek Alluvium was deposited recently. At many places between and immediately upstream from the sections, the stream flows on hard sandstone bedrock of the Upper Cretaceous and Paleocene Denver Formation.

\section{Bear Creek}

Three sections were prepared from borehole logs across Bear Creek (fig. 13). The downstream section $\left(A A-A A^{\prime}\right)$ is located immediately west $(0.6 \mathrm{~km})$ of the confluence with the South Platte River. The middle section $\left(B B-B B^{\prime}\right)$ is located about $5 \mathrm{~km}$ below the confluence of Bear Creek and Turkey
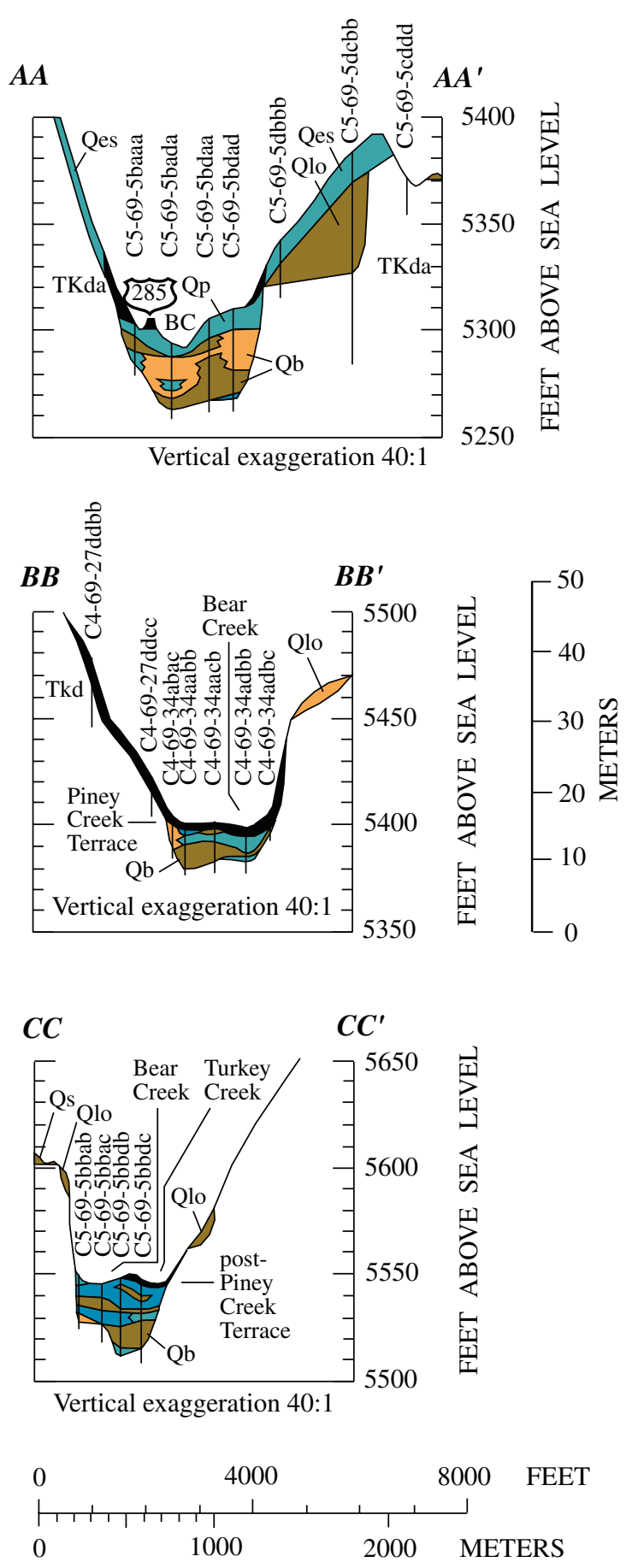

EXPLANATION

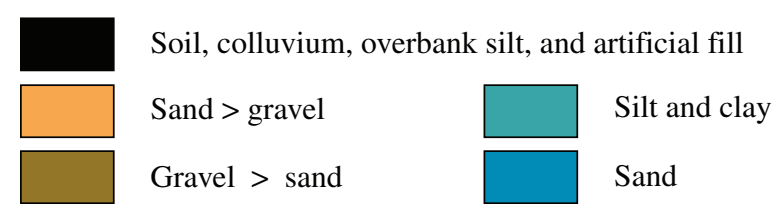

Figure 13. Sections through alluvial fill of the valley of Bear Creek, based on borehole logs reported by McConaghy and others (1964) and geologic maps of Lindvall (1978) and Scott (1972). $A A-A A^{\prime}$, downstream at Federal Boulevard; $B B-B B^{\prime}$, near Kipling Street; $C C-C C$, upstream below Morrison. 
Creek. The upstream section $\left(C C-C C^{\prime}\right)$ is located about $4 \mathrm{~km}$ below Morrison, immediately above the confluence.

Terraces underlain by Verdos, Slocum, and Louviers Alluvium lie above the modern valley on both sides of Bear Creek (Lindvall, 1978; Scott, 1972). Except for the Louviers, these are not paired terraces. South of Bear Creek, remnants of Verdos and Slocum Alluvium (not shown on fig. 13) mark the former course of Bear Creek (Hunt, 1954) or Turkey Creek (Scott, 1972). North of Bear Creek, terraces composed of thin gravel lags of Verdos and Slocum Alluvium extend up the slopes of Green Mountain. East of Morrison, about 3-5 m of Louviers Alluvium forms a narrow terrace along the north side of Bear Creek and a broad terrace upstream from the confluence of Bear Creek and Turkey Creek. The Louviers Alluvium here consists entirely of coarse pebble, cobble, and boulder gravel. At the line of section $C C$ - $C C^{\prime}$, at the confluence of Turkey Creek and Bear Creek, the base of the Louviers Alluvium on the north side of Bear Creek lies about $12 \mathrm{~m}$ above the modern valley surface of Bear Creek; the top (terrace tread) lies $15 \mathrm{~m}$ above the surface. On the south side of Turkey Creek, the Louviers is somewhat lower but still above the valley surface. Downstream, on the south side of the valley of Bear Creek, terrace treads of Louviers Alluvium lie about $15 \mathrm{~m}$ above the modern valley surface (Lindvall, 1978; Scott, 1972).

The alluvial fill of the modern valley is barely $0.6 \mathrm{~km}$ in width. As is the case for Clear Creek (fig. 12), the base of the alluvial fill in Bear Creek has been incised below the base of the Louviers Alluvium (fig. 13). Thus, the modern valley fill is younger than the Louviers terrace fill. East of the downstream section (fig. 13, section $\left.A A-A A^{\prime}\right)$ ), coarse gravel in the lower part of the modern valley fill may meet the basal gravel of the South Platte River (fig. 4, section $S$ - $S^{\prime}$ ), regarded as deposited at the end of Broadway time. The uppermost part of the fill of
Bear Creek valley has been mapped as post-Piney Creek and Piney Creek (Lindvall, 1978; Scott, 1972).

The alluvial fill of Bear Creek is generally 6-12 m thick. Roughly the lower half is dominated by gravel, whereas the upper half is mostly sand that fines downstream to silt and clay. Overall, the fill of Bear Creek approximates a fining-upward aggradation sequence, more or less like that of Lefthand and Boulder Creeks. Like Boulder Creek and Clear Creek, however, the fill is likely of two ages. The lower gravel is probably late Pleistocene (Broadway) in age, whereas the upper half of sand, silt, and clay, mapped as Piney Creek and post-Piney Creek Alluvium (Lindvall, 1978; Scott, 1972), is Holocene.

\section{Rocky Flats Alluvial Fan}

The Rocky Flats Alluvium at Rocky Flats (location shown in fig. 2) underlies a broad, smooth surface that slopes away from the mouth of Coal Creek and ends on promontories about $6-10 \mathrm{~km}$ east of the mountain front (fig. 14). The surface has the form of a gently sloping fan. Radial profiles are concave up with gradients of about $1.5^{\circ}$ near the apex to $0.7^{\circ}$ near the eroded downstream edge. These gradients are below those commonly measured for alluvial fans constructed by sediment gravity flows and sheetflood, which generally exceed $2^{\circ}$, and they are above slopes of $0.4^{\circ}$ or less, common for distributary fans constructed entirely by fluvial processes (Blair and McPherson, 1994a). The continuous, upper part of the surface is very smooth; only patches of dark vegetation mark the remains of in-filled gullies and depressions. At a few places, a north-striking hogback of Upper Cretaceous Fox Hills Sandstone breaks the smooth surface. The hogback con-

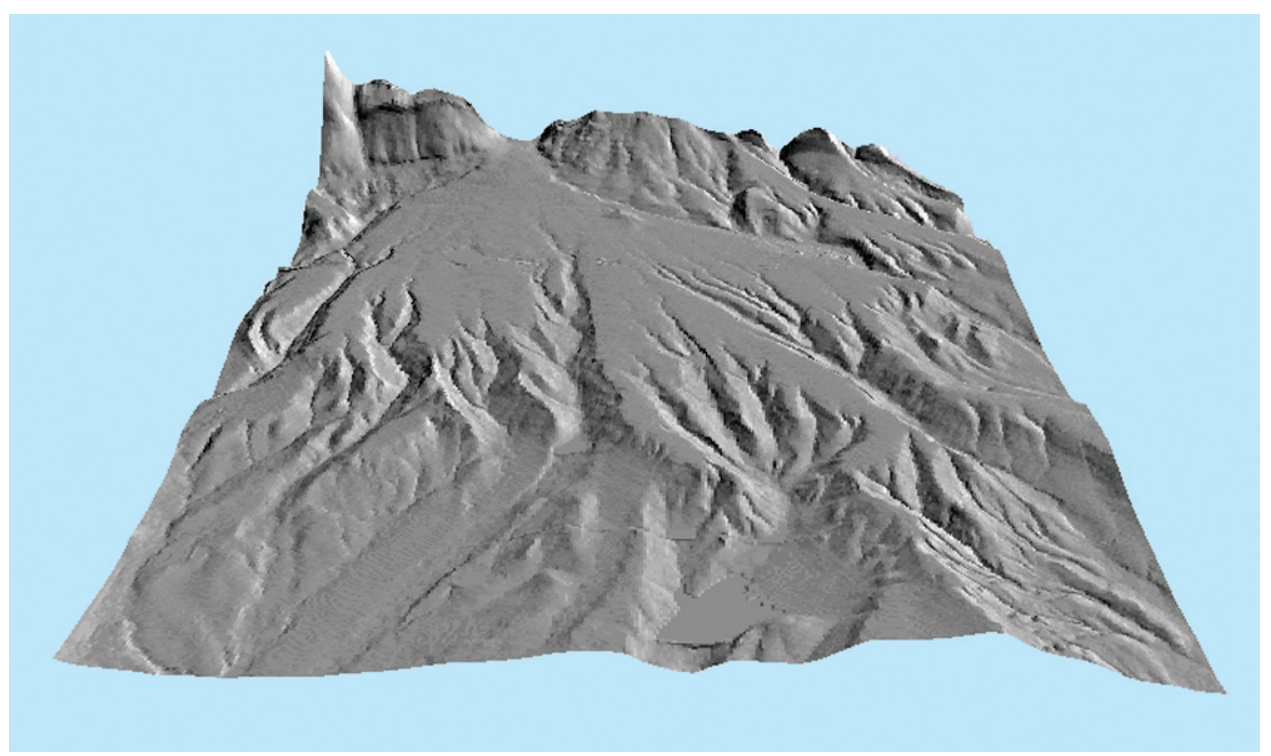

Figure 14. Map showing 3-dimensional digital elevation model of Rocky Flats alluvial fan. View looking west at fan apex at mouth of Coal Creek, with fan tilted toward observer. Modern Coal Creek flows along north (right) side of fan. Tributaries of Big Dry Creek are eroding headward into the fan from the east (foreground). Area is approximately $13 \mathrm{~km}$ on each side. Vertical exaggeration 5×. Prepared by D.H. Knepper, Jr. 
sists of nearly vertical beds of resistant sandstone. The shallow channel of Coal Creek skirts the northern edge of the fan apex; it heads in the same canyon as the fan apex and is incised into the fan downstream from the mouth of Coal Creek Canyon. The eastern margin of the fan has been much dissected by the headward erosion of tributaries of Big Dry Creek, Coal Creek, and Ralston Creek. Successive periods of incision, headward erosion, and lateral cutting by these tributaries are recorded by terraces correlated with Verdos, Slocum, Louviers, and Broadway Alluvium east of Rocky Flats (Lindvall, 1979b; Machette, 1977; Van Horn, 1972).

The thickness and depth of alluvium beneath Rocky Flats (Knepper, 2005) can be mapped from numerous boreholes (Dames and Moore, 1981; EG\&G Rocky Flats, Inc., 1991) and from the elevation of the exposed base of the Rocky Flats Alluvium (Schwochow and others, 2000). A map of the thickness of Rocky Flats Alluvium reveals (1) ponded sediment upstream (west) from the topographic barrier of the Fox Hills hogback and (2) the presence, downstream from the barrier, of small basins and paleovalleys that radiate away from the fan apex (fig. 15). In the southwestern part of the fan, a prominent depression filled with ponded alluvium lies upstream from the hogback. The variation in alluvium thickness indicates that this depression drained through gaps in the hogback, filling another depression downstream (east) from the hogback. Three or four alluvium-filled paleovalleys radiate east and southeast from the downstream depression. In the northern part of the fan, at least two paleovalleys radiate east from the hogback; locally, one paleovalley contains as much as 30 m of alluvium (EG\&G Rocky Flats, Inc., 1991). Although paleovalleys beneath the Rocky Flats Plant were thought to have been reoccupied by modern valleys (EG\&G Rocky Flats, Inc., 1991), the complete map of alluvium thickness presented here (fig. 15) suggests that some alluvium-filled paleovalleys actually underlie modern-day promontories between the headward-eroding tributaries of Big Dry Creek. The promontories, capped by Rocky Flats Alluvium in paleovalleys, are inverted drainages - hills that were once valleys and have been preserved because they contain coarse alluvium that resists erosion (Ritter, 1987). Similar paleovalleys filled with coarse alluvium have been described from Rocky Flats Alluvium near the mountain front at the U.S. Air Force Academy site near Colorado Springs (Varnes and Scott, 1967).

A topographic map of the base of the Rocky Flats Alluvium shows the radial drainage pattern of valleys cut in bedrock by streams that once emerged from Coal Creek Canyon (fig. 16). The courses of former valleys are readily identified and coincide with thick alluvium. The basal surface has long been considered a pediment (Scott, 1960), implying a low-relief erosion surface planed by lateral cutting of streams on bedrock (Mackin, 1970). However, the map clearly shows that the base of the Rocky Flats Alluvium fills depressions and valleys as deep as $25 \mathrm{~m}$. The Fox Hills hogback is also evident. This surface evolved upward into the present smooth

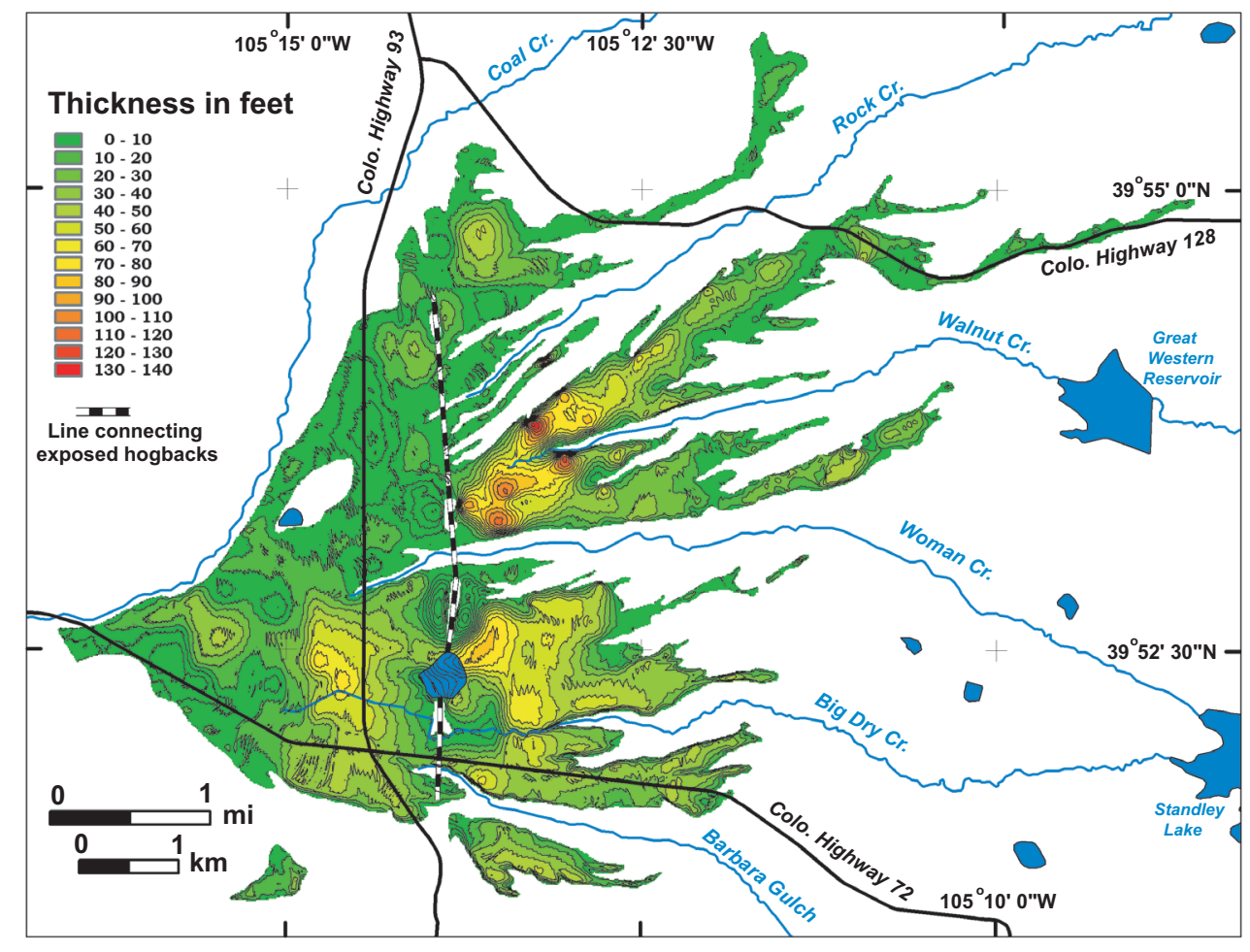

Figure 15. Map showing thickness of Rocky Flats Alluvium at Rocky Flats. Prepared by D.H. Knepper, Jr. 


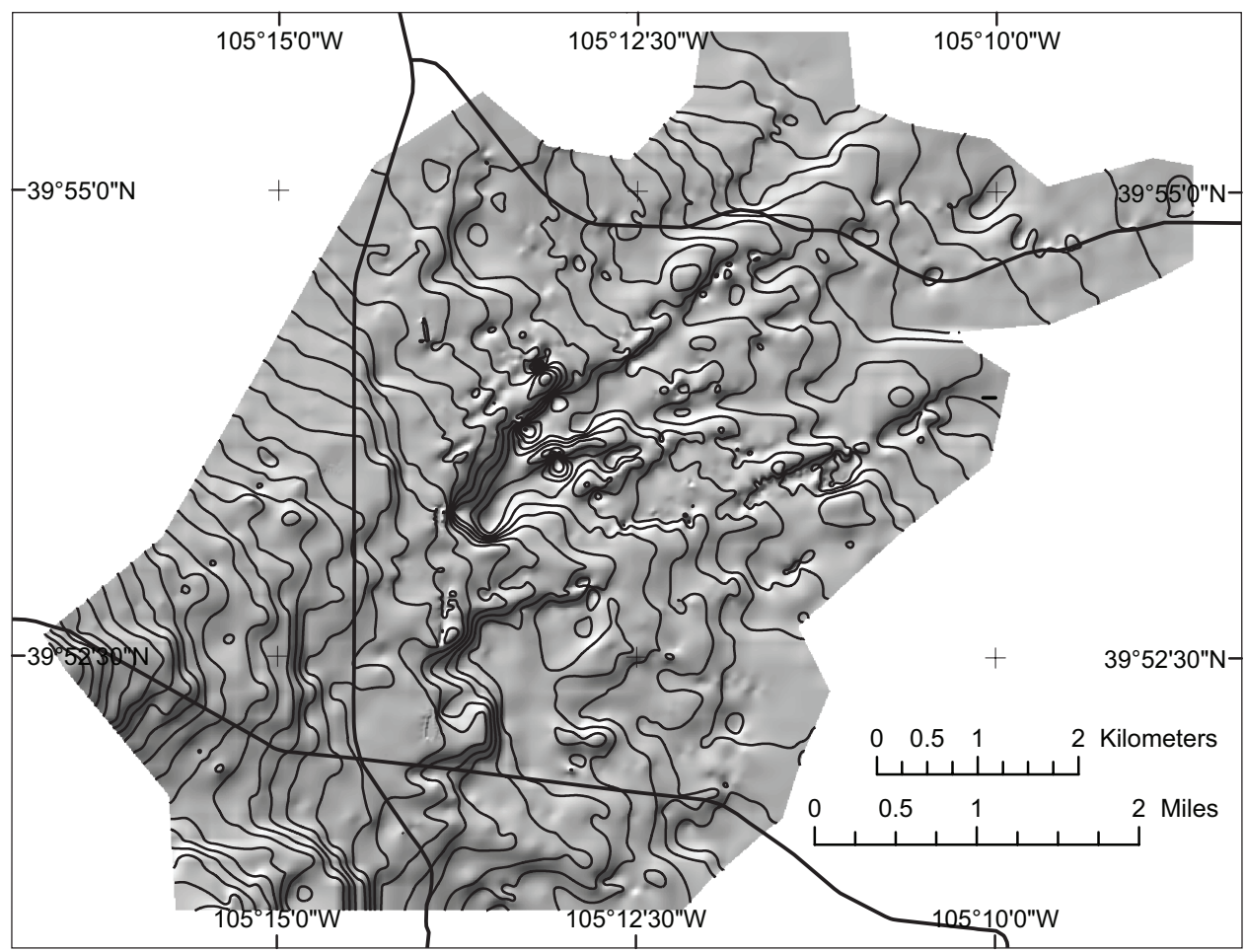

Figure 16. Map showing topography of the base of Rocky Flats Alluvium at Rocky Flats. Shaded area shows limit of map control. Contour interval is $20 \mathrm{ft}(6 \mathrm{~m})$. See figure 14 for distribution of Rocky Flats Alluvium. Dark lines show State highways for reference. Prepared by D.H. Knepper, Jr.

and gentle surface of the top of the Rocky Flats Alluvium by the infilling action of the streams that flowed across it. After depressions and valleys were filled with alluvium, the fan surface was abandoned and subjected to prolonged weathering. The present surface does not reveal the topographic relief beneath the fan alluvium.

The drainage system that deposited the Rocky Flats fan was probably abandoned between 1.5 and $1.35 \mathrm{Ma}$, in early Pleistocene time (ages from Birkeland and others, 1996; Dethier and others, 2001). Verdos Alluvium postdates abandonment of the fan surface; it forms thin fills and lags on drainage divides of distal parts of the Rocky Flats fan. Verdos Alluvium rests on surfaces cut by headward erosion of piedmont tributaries of Coal Creek, Big Dry Creek, and Ralston Creek. At Rocky Flats, possibly 750 ka may have elapsed between deposition of Rocky Flats Alluvium and Verdos Alluvium (Birkeland and others, 1996). Coal Creek, which emerges from Coal Creek Canyon and turns northeast, has probably drained the canyon since the Rocky Flats surface was abandoned. The most likely sequence of events is (1) a stream that flowed east from what is now Coal Creek Canyon into ancestral Big Dry Creek deposited the Rocky Flats alluvial fan at the mountain front; (2) the piedmont stream that became Coal Creek cut headward along the northern margin of the fan and beheaded the mountain reach (Coal Creek Canyon) of ancestral Big Dry Creek; and (3) piedmont tributaries of Coal Creek, Big Dry
Creek, and Ralston Creek have since dissected the distal parts of the fan.

\section{Clast Lithology and Roundness}

\section{Provenance}

In the source area, the topographic relief, the relative abundance of different rock types (lithology), and the weathering of rocks of varying resistance affect the composition of gravel. Although all gravel clasts are ultimately derived from bedrock, only a few are transported directly to their site of deposition. Most clasts are recycled one or more times during transit to their present site, either after storage in gravel bars or in terrace fills. If stored in the zone of weathering, clasts are subject to alteration and destruction, which may change the proportions among lithologies available for further recycling. In addition to recycling from alluvial deposits of late Tertiary and Quaternary age, clasts in the South Platte River basin have been recycled from loosely indurated conglomerate as old as Late Cretaceous.

In the Front Range, gneiss, schist, and granitic rocks are the dominant source rocks. Sources of igneous rock include stocks and batholiths of granitic rocks (including quartz mon- 
zonite, granodiorite, syenite, and other varieties) of Precambrian age and stocks and smaller intrusions of Late Cretaceous and Tertiary age (Braddock and Cole, 1978; Bryant and others, 1981; Gable, 2000; Tweto, 1987). Gneiss, amphibolite, and mica schist are widespread, including near the mountain front west of Golden. Pegmatite dikes intrude metamorphic rocks, especially around the periphery of batholiths. Some batholithic granite is so coarse as to be identical to pegmatite when encountered as clasts in gravel. Metadiabase and quartz occur as dikes and veins in Precambrian terrane. Metamorphic quartzite is abundant in Coal Creek Canyon (Wells and others, 1964). In the foothills between the mountain front and the Denver Basin, sandstone and volcanic (including shallow intrusive) rocks (Braddock and others, 1988; Van Horn, 1972) were important local sources of clasts in alluvium.

In addition to bedrock terrane, a variety of surficial deposits provided local sources of stored clastic sediment. Glacial till and outwash are found in the headwater valleys of major mountain streams, including the South Platte River, Cache la Poudre River, Big and Little Thompson Rivers, St. Vrain Creek, and Clear Creek, and to a minor extent, Lefthand and Bear Creeks (Madole, Van Sistine, and Michael, 1998). This glacial detritus, of middle and late Pleistocene age, was a potential source of clasts in Louviers and younger alluvium of major streams that head in the mountains. East of the mountain front, clasts stored in mountain-front fans and terrace fill may have provided important local sources (e.g., Madole, Braddock, and Colton, 1998; Shroba and Carrara, 1996; Van Horn, 1976). Loosely indurated conglomerate in Upper Cretaceous and Paleocene formations near Golden (Scott, 1972) was an important source for recycled clasts of volcanic rock, vein quartz, gneiss, granitic rocks, and pegmatite.

\section{Dispersion Paths}

The distribution of mafic rocks (amphibolite + schist + diabase), volcanic rocks (mostly gray porphyry of shallow intrusive and extrusive origin), vein quartz, and quartzite was mapped to delineate dispersion paths in alluvium. Dispersion paths record transport of sediment during some time interval; they do not ordinarily reveal the course of individual paleostreams, but they do indicate the gross position of streams draining a source of specific lithologic composition. Each path is specific to a time interval represented by one or more alluvial units. To allow for possible differences in proportions of clast lithologies caused by weathering, localities in Slocum and older alluvium are distinguished from localities in Louviers and younger alluvium by different symbols on maps of clast lithology. Maps are constructed from pebble-count data, as discussed under "Methods and Definitions."

Three dispersion paths were delineated for volcanic rocks (fig. 17). Volcanic clasts (as much as 8 percent felsic, intermediate, and mafic porphyry, Langer and Lindsey, 1999) are locally common in late Pleistocene and Holocene gravel of the lower Cache la Poudre River. Inasmuch as volcanic clasts are generally sparse upstream, the source has not been identified. Perhaps, the volcanic clasts of the Cache la Poudre River valley were derived from old gravel in uplands north of the river. South of the Cache la Poudre drainage system, a second dispersion path of volcanic clasts follows St. Vrain Creek, Lefthand Creek, and Boulder Creek (fig. 17). Both Louviers and younger gravel in each of these stream valleys and older gravel on interfluves contain volcanic clasts. These clasts were probably derived from shallow intrusive rocks like the dacite sills described by Braddock and others (1988) and Trimble (1975) from the mountain front. A third, major dispersion path of volcanic clasts extends northeast from Green Mountain and North and South Table Mountains (fig. 17). These volcanic clasts are derived from the Upper Cretaceous and Paleocene Denver Formation, the Paleocene Green Mountain Conglomerate, and from flows of Paleocene Table Mountain Shoshonite (porphyritic latite) on North and South Table Mountains (Scott, 1972; Van Horn, 1972, 1976). Volcanic clasts are common in alluvium of all ages, from early Pleistocene (Rocky Flats Alluvium) to Holocene. On the slopes of Green Mountain, as much as 26 percent volcanic clasts were counted in gravel mapped by Scott (1972) as Rocky Flats Alluvium, reflecting proximity to the source of volcanic clasts in the Denver Formation (table 1). All three dispersion paths coalesce toward Greeley, and together they indicate the general path traveled by volcanic clasts as they were transported and recycled from older to younger gravels.

Two small dispersion paths are evident from the distribution of mafic rocks (amphibolite + schist + diabase) (fig. 17). A small dispersion path follows Boulder Creek downstream, approximately to the confluence of Coal Creek. A second, larger path follows Ralston and Clear Creeks to the South Platte River and thence north to the confluence of Big Dry Creek with the South Platte. Along Ralston Creek, abundance of mafic rocks is 11-32 percent (table 1). Along Clear Creek, abundance of mafic rocks ranges widely (3-22 percent), but four of six values are above 13 percent (table 1). Downstream from Ralston Creek, abundance of mafic rocks in gravel on the divide between Big Dry Creek and the South Platte River ranges from 3 to 15 percent, with most values above 10 percent (table 1). Both paths probably originate in hornblende gneiss and amphibolite terrane immediately west of the mountain front (Gable, 2000).

A dispersion path of vein quartz was mapped by the distribution of localities having $>5$ percent vein quartz (fig. 18). As drawn, the area of $>5$ percent vein quartz is generalized; a few localities were left outside the area. Much vein quartz was probably derived from the Green Mountain Conglomerate and possibly from other conglomerate lenses in the Upper Cretaceous and Paleocene Denver Formation on Green Mountain (Scott, 1972). Slocum and older alluvium derived from Green Mountain contains 10-19 percent vein quartz (table 1). A second probable source is the gneiss terrane in the mountain reaches of Ralston Creek. Examination of the sillimanite-biotite gneiss terrane of Gable (2000) revealed abundant quartz and pegmatite veins and much residual quartz at the surface. 


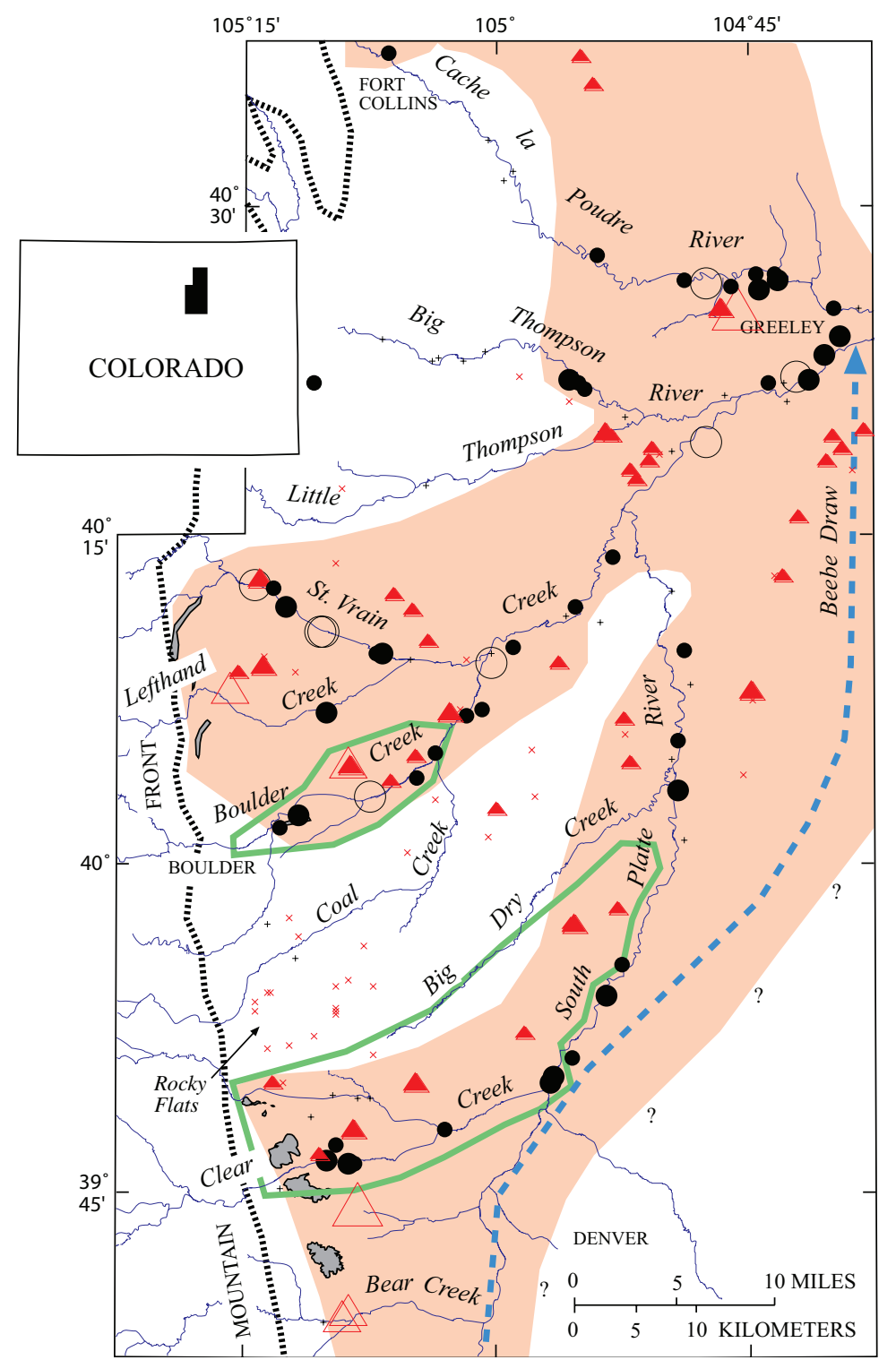

EXPLANATION

Volcanic rocks in percent

Louviers and younger alluvium

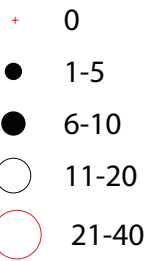

Slocum and older alluvium

$\times \quad 0$

$\therefore \quad 1-5$

- 6-10

$11-20$

$21-40$

Area of volcanic clasts in alluvium

Area of $>5$ percent clasts of amphibolite + schist + diabase in alluvium

Sources of volcanic rock: Tertiary intrusive rocks and Denver Formation flows and conglomerate

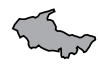

Middle Pleistocene South Platte River

$m=-\infty$

Figure 17. Map showing distribution of volcanic clasts and amphibolite + schist + diabase in alluvium, South Platte River and tributaries, Colorado. G, Greeley. From all available data (Colton and Fitch, 1974; Langer and Lindsey, 1999; Lindsey and Shary, 1997; Lindsey, Langer, and Shary, 1998; Lindsey, this report; Malde, 1955; Van Horn, 1976; and Shroba and Carrara, 1996). Also shown, location of middle Pleistocene South Platte River (Smith and others, 1964; Robson, 1996).

Piney Creek Alluvium in the valley of Ralston Creek, derived from gneiss terrane, contains as much as 19 percent vein quartz (table 1). The dispersion path of vein quartz extends northeast toward Greeley and is especially prominent in gravel assigned by Trimble and Machette (1979) and Colton (1978) to Rocky Flats and Verdos Alluvium. East of the South Platte River, vein quartz is abundant in gravel assigned by Soister (1965b) to pre-Rocky Flats alluvium. Within the dispersion path, Verdos and older alluvium on drainage divides east and west of the South Platte River contains an average of 10-11 percent and reaches a maximum of 16 percent vein quartz (table 1).
For Louviers and younger alluvium in the quartz dispersion path, abundance of vein quartz appears to be highly variable. Louviers and Broadway Alluvium along Clear Creek contains much less vein quartz (average of 4 percent, range of 1-7 percent) than adjacent Piney Creek Alluvium in Ralston Creek (average of 11 percent, range of 2-19 percent) (table 1). As measured in 23 samples from gravel pits north of Denver, Broadway and Holocene gravel of the South Platte River valley contain an average of 7-8 percent and a range of 5-11 percent vein quartz among field localities (table 2) (Lindsey, Langer, and Shary, 1998). In gravel sampled from four bars in the modern South Platte River, vein quartz averages 6-7 
Table 1. Pebble lithology and roundness in single samples of gravel, early Pleistocene to Holocene alluvium, South Platte River and tributaries east of the Front Range, Colorado.

[Pebble size: $1-3$ in $(2.5-7.6 \mathrm{~cm})$. All localities represented by counts of approximately 100 pebbles. Field locality numbers located on fig. 3 and by UTM (Universal Transverse Mercator) coordinates; UTM East is in zone 13. Localities listed in downstream order. Qprf, pre-Rocky Flats alluvium; Qrf, Rocky Flats Alluvium; Qv, Verdos Alluvium; Qs, Slocum Alluvium; Qlo, Louviers Alluvium; Qb, Broadway Alluvium; Qp, Piney Creek Alluvium; Qpp, post-Piney Creek Alluvium. Sources for correlation of units: Bear Creek and Green Mountain (Scott, 1972); Clear Creek (Baker, 1973, 1974; Lindvall, 1979b; Van Horn, 1972); Ralston Creek (Baker, 1973, 1974; Van Horn, 1972; Lindvall, 1979b); Rocky Flats-upper Big Dry Creek (Lindvall, 1979b; Machette, 1977; Shroba and Carrara, 1996; Van Horn, 1972); Lefthand Creek (Trimble, 1975); Little Thompson River (Colton, 1978); drainage divide, west side South Platte River (Trimble and Machette, 1979; Soister, 1965a); South Platte River (Lindsey, Langer, Cummings, and Shary, 1998); drainage divide, east side South Platte River (Colton, 1978; Soister, 1965a, 1965b, 1965c). Roundness classes: A, angular; B, subangular; C, subround; D, rounded; E, well-rounded. Average roundness $=(0.125 \mathrm{~A}+0.2 \mathrm{~B}+0.315 \mathrm{C}+0.5 \mathrm{D}+0.8 \mathrm{E}) / 100$. Counts by D. A. Lindsey $]$

\begin{tabular}{|c|c|c|c|c|c|c|c|c|c|c|c|c|c|c|c|}
\hline \multirow{2}{*}{$\frac{\text { Area }}{\text { Field locality }}$} & \multirow{2}{*}{\begin{tabular}{|c|} 
Bear Creek \\
58
\end{tabular}} & \multicolumn{3}{|c|}{ Green Mountain } & \multicolumn{7}{|c|}{ Clear Creek } & \multicolumn{4}{|c|}{ Ralston Creek } \\
\hline & & 66 & 67 & 70 & 53 & 72 & 48 & 73 & 52 & 42 & 57 & 44 & 45 & 43 & 41 \\
\hline UTM-North & 484844 & 486980 & 486418 & 487783 & 485048 & 485346 & 486790 & 487395 & 487369 & 495101 & 492795 & 481346 & 485590 & 487795 & 488684 \\
\hline UTM-East & 4389125 & 4389876 & 4389352 & 4398703 & 4402716 & 4402694 & 4402608 & 4402607 & 4405063 & 4405427 & 4409008 & 4409365 & 4408134 & 4408003 & 4407981 \\
\hline Correlation & Qlo & Qv & Qs & Qrf & Qlo & Qlo & $\mathrm{Qb}$ & $\mathrm{Qb}$ & Qs & $\mathrm{Qb}$ & Qrf & Qv & Qpc & Qpc & Qpc \\
\hline $\begin{array}{l}\text { Glaciated } \\
\text { headwaters }\end{array}$ & No & No & No & No & Yes & Yes & Yes & Yes & $?$ & Yes & $?$ & No & No & No & No \\
\hline
\end{tabular}

\begin{tabular}{ll}
\hline Lithology in percent & L
\end{tabular}

\begin{tabular}{|c|c|c|c|c|c|c|c|c|c|c|c|c|c|c|c|}
\hline Granite $^{1}$ & 12 & 4 & 9 & 10 & 30 & 22 & 26 & 13 & 28 & 24 & 14 & 5 & 3 & 4 & 0 \\
\hline Gneiss & 50 & 13 & 18 & 19 & 26 & 44 & 23 & 46 & 24 & 36 & 32 & 29 & 33 & 19 & 37 \\
\hline Pegmatite & 20 & 28 & 36 & 32 & 14 & 5 & 21 & 20 & 34 & 24 & 26 & 15 & 16 & 30 & 20 \\
\hline Vein quartz & 2 & 19 & 13 & 10 & 1 & 3 & 7 & 2 & 2 & 6 & 4 & 2 & 17 & 8 & 19 \\
\hline Quartzite & 0 & 0 & 0 & 0 & 0 & 0 & 0 & 0 & 0 & 0 & 0 & 11 & 2 & 1 & 2 \\
\hline Volcanic rocks $^{2}$ & 0 & 17 & 11 & 26 & 6 & 5 & 6 & 4 & 7 & 3 & 6 & $0^{5}$ & 0 & 0 & 0 \\
\hline Mafic rocks ${ }^{3}$ & 14 & 5 & 2 & 2 & 22 & 20 & 13 & 13 & 4 & 3 & 18 & 33 & 25 & 25 & 11 \\
\hline $\begin{array}{l}\text { Sedimentary } \\
\text { rocks }^{4}\end{array}$ & 2 & 14 & 11 & 0 & 1 & 1 & 4 & 2 & 1 & 4 & 0 & 5 & 4 & 13 & 11 \\
\hline
\end{tabular}

Roundness class in percent

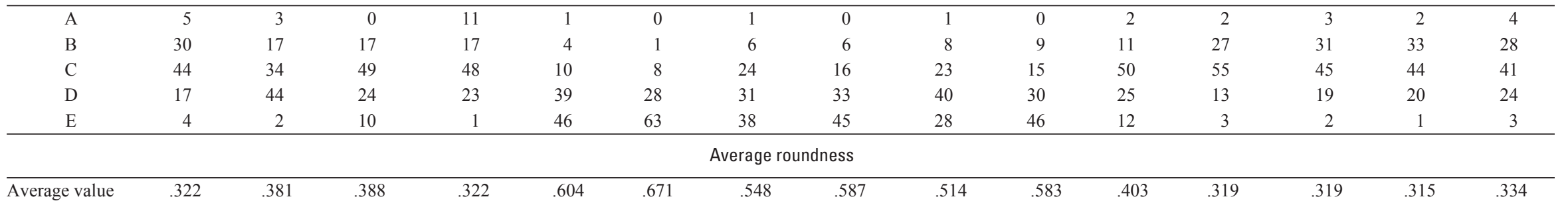


Table 1. Pebble lithology and roundness in single samples of gravel, early Pleistocene to Holocene alluvium, South Platte River and tributaries east of the Front Range, ColoradoContinued.

\begin{tabular}{|c|c|c|c|c|c|c|c|c|c|c|c|c|c|c|c|}
\hline \multirow[b]{2}{*}{ Field locality } & \multicolumn{4}{|c|}{ Rocky Flats-upper Big Dry Creek } & \multirow{2}{*}{$\begin{array}{r}\begin{array}{c}\text { Lefthand } \\
\text { Creek }\end{array} \\
68\end{array}$} & \multirow{2}{*}{$\begin{array}{c}\begin{array}{c}\text { Little } \\
\text { Thompson } \\
\text { River }\end{array} \\
20\end{array}$} & \multicolumn{5}{|c|}{$\begin{array}{l}\text { Drainage divide between Big Dry Creek } \\
\text { and South Platte River }\end{array}$} & \multirow{2}{*}{\begin{tabular}{|c|}
$\begin{array}{c}\text { South Platte } \\
\text { River }\end{array}$ \\
71
\end{tabular}} & \multicolumn{3}{|c|}{$\begin{array}{l}\text { Drainage divide between } \\
\text { South Platte River } \\
\text { and Beebe Draw }\end{array}$} \\
\hline & 47 & 50 & 49 & 39 & & & 62 & $51 \mathrm{~A}$ & 51 & 64 & 10 & & 60 & 19 & 46 \\
\hline UTM-North & 480002 & 485825 & 489012 & 489157 & 484905 & 509662 & 502230 & 506210 & 506478 & 510363 & 511403 & 504345 & 521064 & 521658 & 524233 \\
\hline UTM-East & 4416768 & 4415152 & 4417485 & 4411506 & 4440264 & 4463588 & 4413200 & 4422409 & 4422408 & 4423649 & 4435943 & 4409370 & 4435282 & 4441872 & 4451858 \\
\hline Correlation & Qrf & Qv & Qv & Qv & Qlo & Qs & Qrf & Qrf & Qrf & Qv & Qv & Qpp & Qprf & Qprf & Qrf \\
\hline Glaciated & No & No & No & No & No & Yes & $?$ & $?$ & $?$ & $?$ & $?$ & Yes & $?$ & $?$ & $?$ \\
\hline
\end{tabular}

\begin{tabular}{ll}
\hline & Lithology in percent
\end{tabular}

\begin{tabular}{|c|c|c|c|c|c|c|c|c|c|c|c|c|c|c|c|}
\hline Granite $^{1}$ & 0 & 0 & 0 & 3 & 28 & 23 & 14 & 12 & 24 & 15 & 28 & 9 & 25 & 30 & 20 \\
\hline Gneiss & 21 & 16 & 20 & 17 & 22 & 13 & 24 & 21 & 6 & 20 & 7 & 56 & 16 & 12 & 23 \\
\hline Pegmatite & 9 & 5 & 9 & 6 & 25 & 26 & 30 & 15 & 32 & 33 & 28 & 9 & 23 & 23 & 27 \\
\hline Vein quartz & 3 & 8 & 2 & 14 & 2 & 20 & 8 & 16 & 6 & 9 & 14 & 4 & 14 & 11 & 8 \\
\hline Quartzite & 64 & 69 & 69 & 52 & 0 & 0 & 7 & 14 & 4 & 7 & 12 & 1 & 12 & 9 & 15 \\
\hline Volcanic rocks ${ }^{2}$ & 0 & 0 & 0 & 0 & 8 & 0 & 1 & 3 & 8 & 3 & 3 & 6 & 0 & 4 & 0 \\
\hline Mafic rocks ${ }^{3}$ & 2 & 1 & 0 & 6 & 4 & 12 & 12 & 15 & 14 & 11 & 3 & 11 & 5 & 3 & 0 \\
\hline $\begin{array}{l}\text { Sedimentary } \\
\text { rocks }^{4}\end{array}$ & 1 & 1 & 0 & 2 & 11 & 6 & 4 & 4 & 6 & 2 & 5 & 4 & 5 & 8 & 7 \\
\hline
\end{tabular}

rocks $^{4} \quad$ Roundness class in percent

\begin{tabular}{|c|c|c|c|c|c|c|c|c|c|c|c|c|c|c|c|}
\hline $\mathrm{A}$ & 3 & 7 & 11 & 10 & 0 & 0 & 1 & 3 & 4 & 1 & 0 & 0 & 6 & 0 & 0 \\
\hline B & 31 & 39 & 46 & 37 & 5 & 12 & 11 & 14 & 7 & 14 & 2 & 3 & 13 & 8 & 4 \\
\hline $\mathrm{C}$ & 38 & 31 & 32 & 46 & 57 & 30 & 42 & 29 & 23 & 34 & 33 & 32 & 28 & 25 & 31 \\
\hline D & 28 & 23 & 11 & 6 & 26 & 33 & 33 & 36 & 55 & 42 & 47 & 34 & 33 & 45 & 48 \\
\hline $\mathrm{E}$ & 0 & 0 & 0 & 1 & 12 & 25 & 13 & 18 & 11 & 9 & 18 & 31 & 20 & 22 & 17 \\
\hline \multicolumn{16}{|c|}{ Average roundness } \\
\hline Average value & .325 & .299 & .262 & .269 & .416 & .484 & .425 & .447 & .454 & .418 & .487 & .525 & .447 & .496 & .482 \\
\hline
\end{tabular}

${ }^{1}$ Includes igneous rocks of intermediate composition.

${ }^{2}$ Mostly porphyritic rocks; includes minor scoria and tuff.

${ }^{3}$ Amphibolite, biotite schist, and diabase.

${ }^{4}$ Mostly sandstone; includes < one percent claystone, shale and petrified wood.

${ }^{5}$ Cobbles and boulders of porphyritic volcanic rock in Verdos Alluvium nearby. 


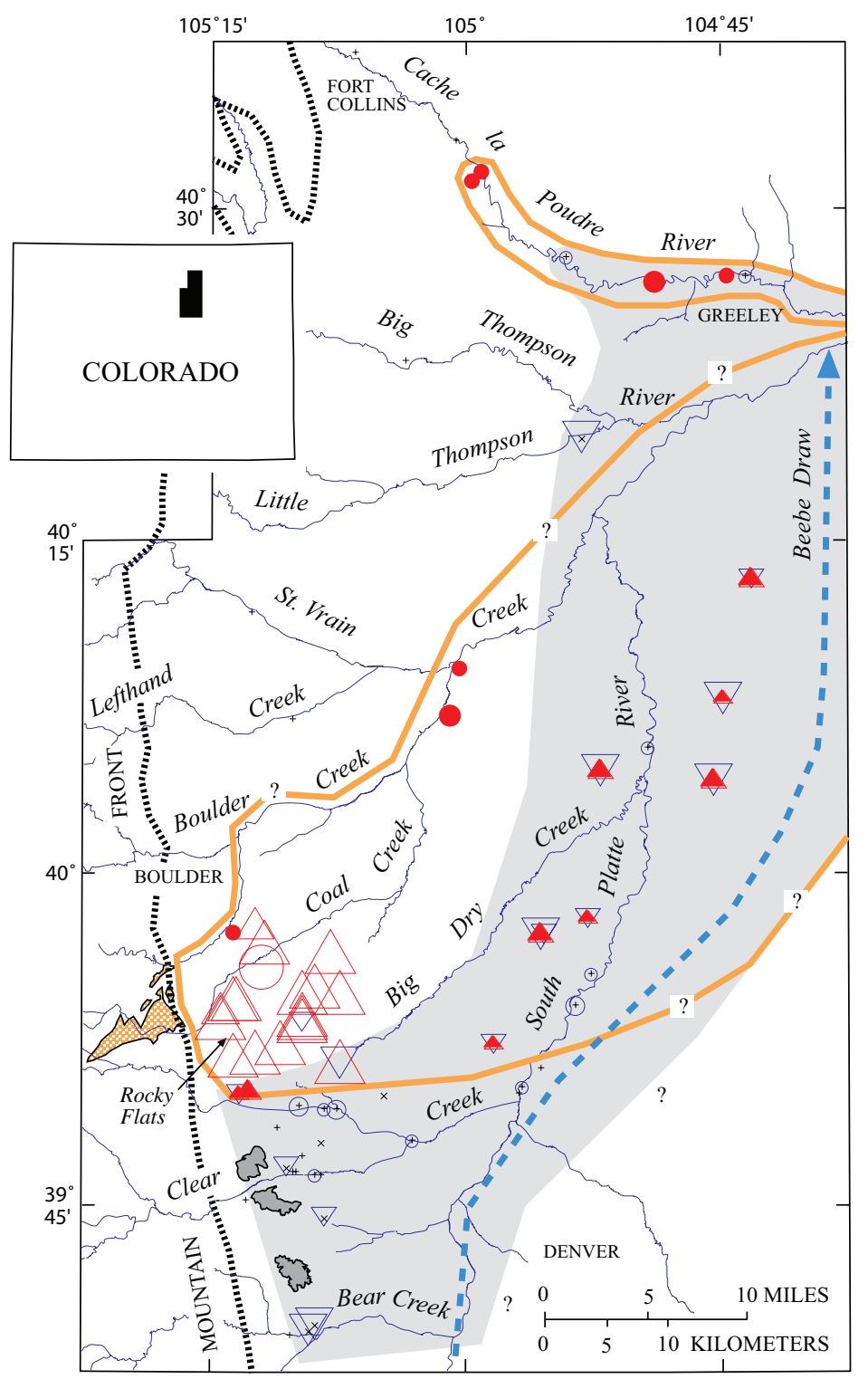

\section{EXPLANATION}

Vein quartz (left symbol) and quartzite (right symbol) in percent

Louviers and younger alluvium

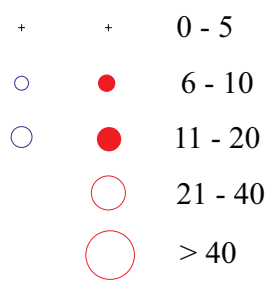

Slocum and older alluvium

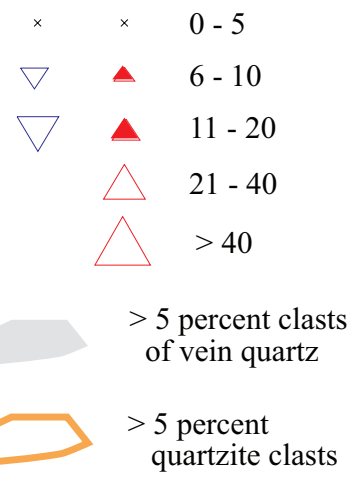

Conglomerate and volcanic rock of Denver Formation

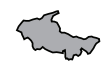

Quartzite of Coal Creek

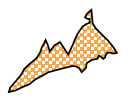

Middle Pleistocene South Platte River

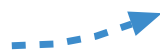

Figure 18. Map showing source and distribution vein quartz and quartzite clasts in alluvium, South Platte River and tributaries, Colorado. From all available data (Langer and Lindsey, 1999; Lindsey and Shary, 1997; Lindsey, Langer, and Shary, 1998; Lindsey, this report; Malde, 1955; and Shroba and Carrara, 1996). Quartzite of Coal Creek from Gable (2000). Also shown, location of middle Pleistocene South Platte River (Smith and others, 1964; Robson, 1996).

percent (Lindsey and Shary, 1997). In gravel pits, no significant differences in abundance of vein quartz were detected among the three units (upper gravel, middle sandy gravel, and basal gravel) in the modern valley of the South Platte River. In gravel bars located $29 \mathrm{~km}$ apart in the river, no significant downstream difference in abundance was detected.

A large dispersion path of quartzite clasts extends east and northeast from the mouth of Coal Creek (fig. 18). Distinctive gray-colored clasts of Precambrian metaquartzite dominate the Rocky Flats and younger alluvium immediately downstream from Rocky Flats. The quartzite is derived from metamorphic quartzite interleaved with gneiss that crops out in
Coal Creek Canyon (fig. 19A) (Wells and others, 1964; Wells, 1967; Gable, 2000). Metaquartzite clasts from Coal Creek Canyon are found as far east as the divide between the South Platte River and Beebe Draw, a distance of $60 \mathrm{~km}$ (fig. 19B). Gravel at Rocky Flats (Rocky Flats Alluvium and younger gravel derived from Rocky Flats Alluvium) contains approximately 50-90 percent quartzite (table 1) (Malde, 1955; Shroba and Carrara, 1996).

Downstream from Rocky Flats, where the dispersion paths of volcanic rocks and vein quartz from the south cross that of quartzite, quartzite abundance is diluted by these rocks and by major quantities of gneiss, granite, and peg- 
Table 2. Pebble lithology and roundness in composite samples of gravel, latest Pleistocene Broadway(?) and Holocene Alluvium, the South Platte River and tributaries east of the Front Range, Colorado (Front Range Infrastructure Project).

[Pebble size: $0.75-1.5$ in (1.9-3.8 cm). All localities represented by composites of two or more samples of 50 pebbles each; in pits, average of entire thickness of gravel; on gravel bars (WE and FL), average of upstream and downstream samples. Field locality letters located on fig. 3 and by UTM (Universal Transverse Mercator) coordinates; UTM East is in zone 13. Localities listed in downstream order. Qb ?, latest Pleistocene Broadway(?) Alluvium; Qpp, Holocene post-Piney Creek Alluvium; --, alluvium in active streambed. All streams have glaciated headwater valleys. Sources of correlations and data: Cache la Poudre River (Langer and Lindsey, 1999); Boulder Creek, St. Vrain Creek, and Big Thompson River (Front Range Infrastructure Project, unpublished); South Platte River alluvium (Lindsey, Langer, and Shary, 1998); South Platte River gravel bars (Lindsey and Shary, 1997). Roundness classes: A, angular; B, subangular; C, subround; D, rounded; E, well-rounded. Average roundness $=(0.125 \mathrm{~A}+0.2 \mathrm{~B}+$ $0.315 \mathrm{C}+0.5 \mathrm{D}+0.8 \mathrm{E}) / 100$

\begin{tabular}{|c|c|c|c|c|c|c|c|c|c|c|c|c|c|c|c|c|c|}
\hline \multirow{2}{*}{$\begin{array}{c}\text { Area } \\
\text { Field locality }\end{array}$} & \multicolumn{8}{|c|}{ Cache la Poudre River } & \multicolumn{2}{|c|}{ Boulder Creek } & \multirow{2}{*}{$\begin{array}{c}\begin{array}{c}\text { St. Vrain } \\
\text { Creek }\end{array} \\
\text { L }\end{array}$} & \multirow{2}{*}{\begin{tabular}{|c|c}
$\begin{array}{c}\text { Big } \\
\text { Thompson } \\
\text { River }\end{array}$ \\
B
\end{tabular}} & \multicolumn{3}{|c|}{$\begin{array}{l}\text { South Platte River } \\
\text { alluvium }\end{array}$} & \multicolumn{2}{|c|}{$\begin{array}{l}\text { South Platte River } \\
\text { gravel bars }\end{array}$} \\
\hline & $\mathrm{TH}$ & POE & TM & $\mathrm{W}$ & HIW & HIG & $35 \mathrm{TH}$ & GW & $\mathrm{N}$ & $\mathrm{H}$ & & & ND & HP & ML & WE & FL \\
\hline UTM-North & 490380 & 499000 & 501000 & 500350 & 508300 & 515800 & 521950 & 523600 & 498300 & 499160 & 481470 & 494550 & 506320 & 509120 & 510500 & 504550 & 515200 \\
\hline UTM-East & 4495720 & 4488500 & 4485850 & 4485000 & 4478800 & 4476800 & 4477250 & 4477200 & 4440650 & 4444700 & 4449400 & 4470100 & 4411440 & 4416560 & 4419200 & 4409680 & 4438050 \\
\hline Correlation & Qpp-Qb? & Qpp-Qb? & Qpp-Qb? & Qpp-Qb? & Qpp-Qb? & Qpp-Qb? & ? Qpp-Qb? & Qpp-Qb? & Qpp-Qb? & Qpp-Qb? & Qpp-Qb? & Qpp-Qb? & $\begin{array}{l}\text { Qpp- } \\
\text { Qb?- }\end{array}$ & Qpp-Qb? & ? Qpp-Qb? & -- & -- \\
\hline \multicolumn{18}{|c|}{ Lithology in percent } \\
\hline Granite $^{1}$ & 24.0 & 23.3 & 27.5 & 24.5 & 30.0 & 26.5 & 18.0 & 22.5 & 41.0 & 56.0 & 66.0 & 51.0 & 24.0 & 25.8 & 23.8 & 34.3 & 32.0 \\
\hline Gneiss & 10.0 & 6.7 & 10.0 & 14.0 & 6.5 & 5.0 & 5.0 & 4.0 & 11.0 & 9.0 & 17.0 & 34.0 & 19.2 & 23.5 & 25.8 & 24.3 & 20.0 \\
\hline Pegmatite & 45.0 & 53.3 & 47.5 & 46.0 & 38.5 & 49.5 & 51.0 & 51.0 & 15.0 & 2.0 & 2.0 & 3.0 & 38.3 & 26.0 & 31.1 & 12.3 & 24.7 \\
\hline Vein quartz & 2.0 & 2.0 & 2.0 & 3.5 & 11.5 & 3.0 & 6.0 & 9.0 & 3.0 & 2.0 & 1.0 & 3.0 & 5.3 & 10.8 & 6.4 & 6.3 & 7.3 \\
\hline Quartzite & 3.0 & 5.3 & 10.0 & 8.0 & 4.5 & 13.0 & 10.0 & 5.0 & 19.0 & 10.0 & 1.0 & 2.0 & 3.3 & .2 & 1.1 & 0.0 & .3 \\
\hline Volcanic rocks ${ }^{2}$ & 2 & $3 \mathrm{E}-1$ & $5 \mathrm{E}-1$ & 0 & 4 & 2 & 3 & 4 & 4 & 11 & 9 & 0 & 4 & 6 & 3 & 7 & 5 \\
\hline Mafic rocks ${ }^{3}$ & 11.0 & 4.7 & 2.0 & 1.5 & 4.5 & .5 & 5.0 & 2.5 & 0.0 & 0.0 & 0.0 & 0.0 & 3.0 & 2.7 & 1.6 & 7.7 & 3.7 \\
\hline $\begin{array}{l}\text { Sedimentary } \\
\text { rocks }^{4}\end{array}$ & 3.0 & 3.3 & .5 & 2.5 & .5 & 1.0 & 2.0 & 2.0 & 7.0 & 10.0 & 4.0 & 7.0 & 3.0 & 5.5 & 4.4 & 8.3 & 7.0 \\
\hline \multicolumn{18}{|c|}{ Roundness class in percent } \\
\hline $\mathrm{A}$ & 3.0 & 4.3 & 5.5 & 3.3 & 5.0 & 2.5 & 2.0 & 2.0 & 0.0 & 0.0 & 1.0 & 0.0 & 1.0 & 2.5 & 2.0 & 4.7 & 5.3 \\
\hline B & 6.0 & 9.3 & 10.5 & 9.3 & 10.5 & 8.5 & 5.0 & 4.0 & 9.0 & 0.0 & 5.0 & 0.0 & 4.7 & 11.3 & 14.7 & 6.3 & 15.7 \\
\hline $\mathrm{C}$ & 6.0 & 12.7 & 19.0 & 18.0 & 20.5 & 19.5 & 14.0 & 10.5 & 32.0 & 19.0 & 21.0 & 23.0 & 20.7 & 21.0 & 27.3 & 16.0 & 21.7 \\
\hline $\mathrm{D}$ & 22.0 & 25.7 & 25.0 & 21.4 & 32.5 & 41.0 & 31.0 & 32.5 & 38.0 & 66.0 & 49.0 & 57.0 & 33.4 & 33.4 & 33.3 & 27.0 & 33.0 \\
\hline $\mathrm{E}$ & 63.0 & 48.0 & 40.0 & 48.0 & 31.5 & 28.5 & 48.0 & 51.0 & 21.0 & 15.0 & 24.0 & 20.0 & 40.2 & 31.8 & 22.7 & 46.0 & 24.3 \\
\hline \multicolumn{18}{|c|}{ Average roundness } \\
\hline Average value & .649 & .576 & .533 & .570 & .506 & .515 & .596 & .614 & .477 & .510 & .514 & .517 & .564 & .513 & .466 & .572 & .466 \\
\hline
\end{tabular}

${ }^{1}$ Includes igneous rocks of intermediate composition.

${ }^{2}$ Mostly porphyritic rocks; includes minor tuff.

${ }^{3}$ Amphibolite, biotite schist, and diabase.

${ }^{4}$ Mostly sandstone; includes $<$ one percent claystone, shale and petrified wood. 

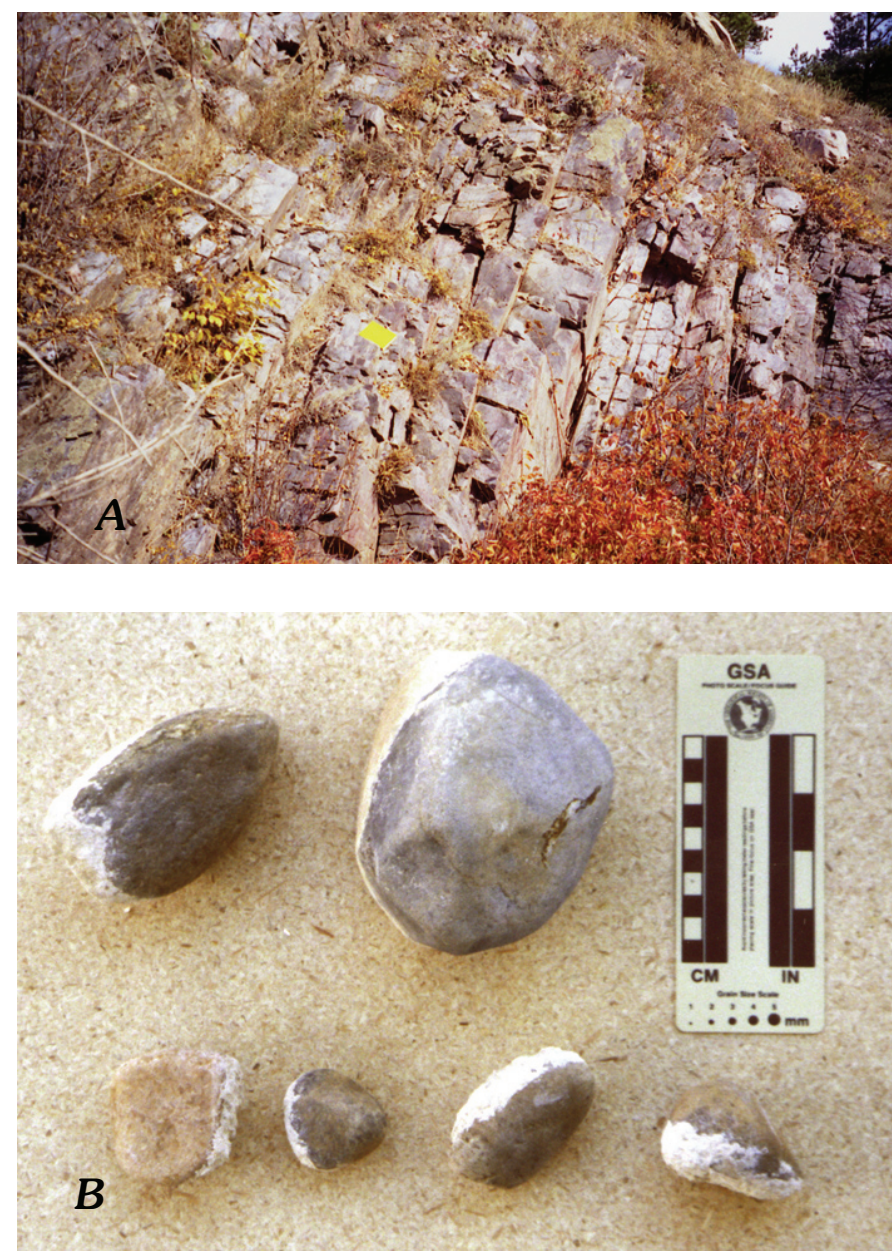

Figure 19. Photographs of $A$, Outcrop of bedded Precambrian metaquartzite in Coal Creek Canyon, thought to be the source of quartzite clasts at Riley Mound. Yellow notebook is $15 \mathrm{~cm}$ across. $B$, Metaquartzite clasts found in gravel at Riley Mound (locality 19, fig. 3), correlated with pre-Rocky Flats alluvium (Soister, 1965b; Scott, 1982); note calcium carbonate coatings on clasts; scale in centimeters and inches).

matite. This contrast is illustrated by variation in abundance of quartzite versus gneiss + granite + pegmatite in alluvium along an east-west transect from the mountain front west of Rocky Flats to the drainage divide east of the South Platte River (fig. 20A). To minimize differences that may be attributed to weathering, only Verdos and older alluvium are first compared; the composition of latest Pleistocene Broadway and Holocene alluvium in the modern valley of the South Platte River will be discussed separately. To avoid possible differences among pebble counts by different workers, only data collected by D.A. Lindsey (table 1) is compared. On Rocky Flats and upper Big Dry Creek, Rocky Flats and Verdos Alluvium contain 52-69 percent quartzite (fig. 20B). In contrast, on the divide between Big Dry Creek and the South Platte River, the distinctive bluish-gray quartzite from Coal Creek Canyon comprises only 4-14 percent of pebbles in Rocky Flats and Verdos Alluvium (fig. 20B). On the divide between the South Platte River and Beebe Draw, quartzite from Coal Creek Canyon comprises 9-15 percent of clasts in gravel assigned to Rocky Flats (field locality 46) and pre-Rocky Flats (field localities 19 and 60) Alluvium (table 1). The average abundance of quartzite in Verdos and older alluvium on both drainage divides is $10-11$ percent. Colton and Fitch (1974) reported as much as 67 percent quartzite from localities between the South Platte River and Beebe Draw, but they did not distinguish vein quartz from quartzite and apparently included it with the latter. The sharp differences between quartzite abundance near Rocky Flats and the drainage divides is compensated by the abundance of gneiss + granite + pegmatite (fig. 20C). The total for gneiss + granite + pegmatite is about 21-30 percent near Rocky Flats but is 48-70 percent on drainage divides to the east (table 1).

Abundance of minor lithologies also reveals the difference between alluvium at Rocky Flats and the drainage divides on both sides of the South Platte River. At Rocky Flats, volcanic rocks are absent and mafic rocks are 6 percent or less in Rocky Flats and Verdos Alluvium. On the divide between Big Dry Creek and the South Platte River, volcanic rocks comprise 1-8 percent of clasts and mafic rocks comprise another 11-15 percent (table 1). On the divide between the South Platte River and Beebe Draw, volcanic rocks are present in Rocky Flats Alluvium but sparse or absent in pre-Rocky Flats Alluvium (table 1). Mafic rocks comprise 5 percent or less.

The abundance of quartzite in latest Pleistocene Broadway and younger alluvium of the modern South Platte River valley is much less than that of Verdos and older alluvium on adjacent drainage divides (fig. 20B). As measured in 23 samples from gravel pits north of Denver, gravel fill of the South Platte River contains an average of less than 1 percent to about 3 percent quartzite (table 2) (Lindsey, Langer, and Shary, 1998). In modern gravel bars of the South Platte River near Fort Lupton, located within the dispersion path of quartzite, average abundance of quartzite is less than 1 percent (table 2) (Lindsey and Shary, 1997).

The dispersion paths of volcanic clasts and vein quartz in gravel, and the dilution of quartzite clasts where the dispersion paths cross that of quartzite from the head of Coal Creek, are strong evidence that early Pleistocene streams flowed north near the present course of the South Platte River. All of these dispersion paths were well established during deposition of Rocky Flats and Verdos Alluvium in early and middle Pleistocene time (figs. 17 and 18). Evidently, an early Pleistocene stream formed by the confluence of ancestral Big Dry Creek, Ralston Creek, and Clear Creek flowed north to join other ancestral tributaries of the South Platte River near Greeley. We do not know whether this early Pleistocene stream included the South Platte itself, but it may have. At some point, probably during middle Pleistocene time, the ancestral South Platte River flowed northeast through Beebe Draw, rejoining the Cache la Poudre and northern tributaries east of Greeley (Smith and others, 1964). The paleovalley fill of this course of the ancestral South Platte has been explored and mapped 


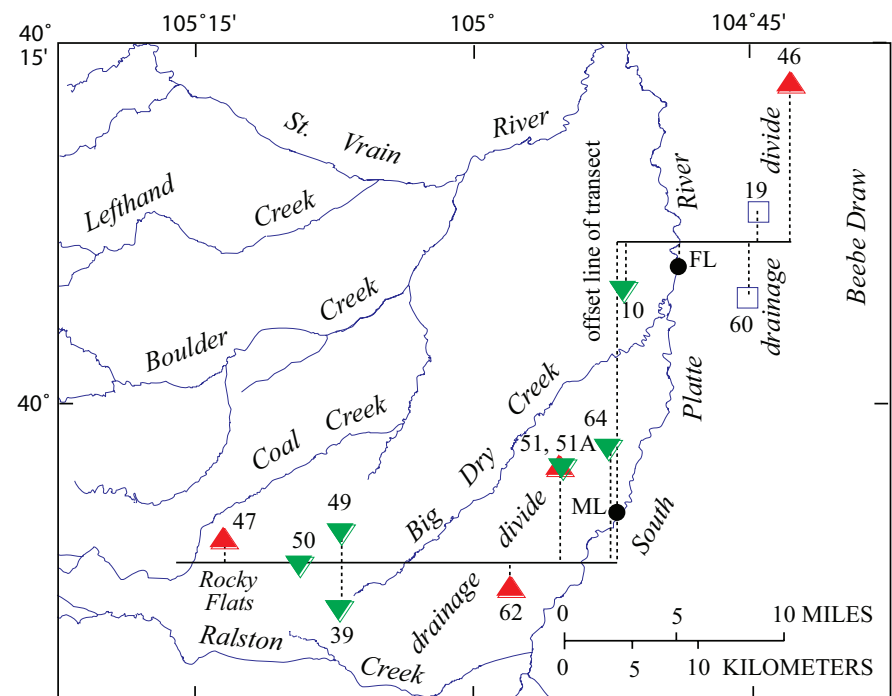

A
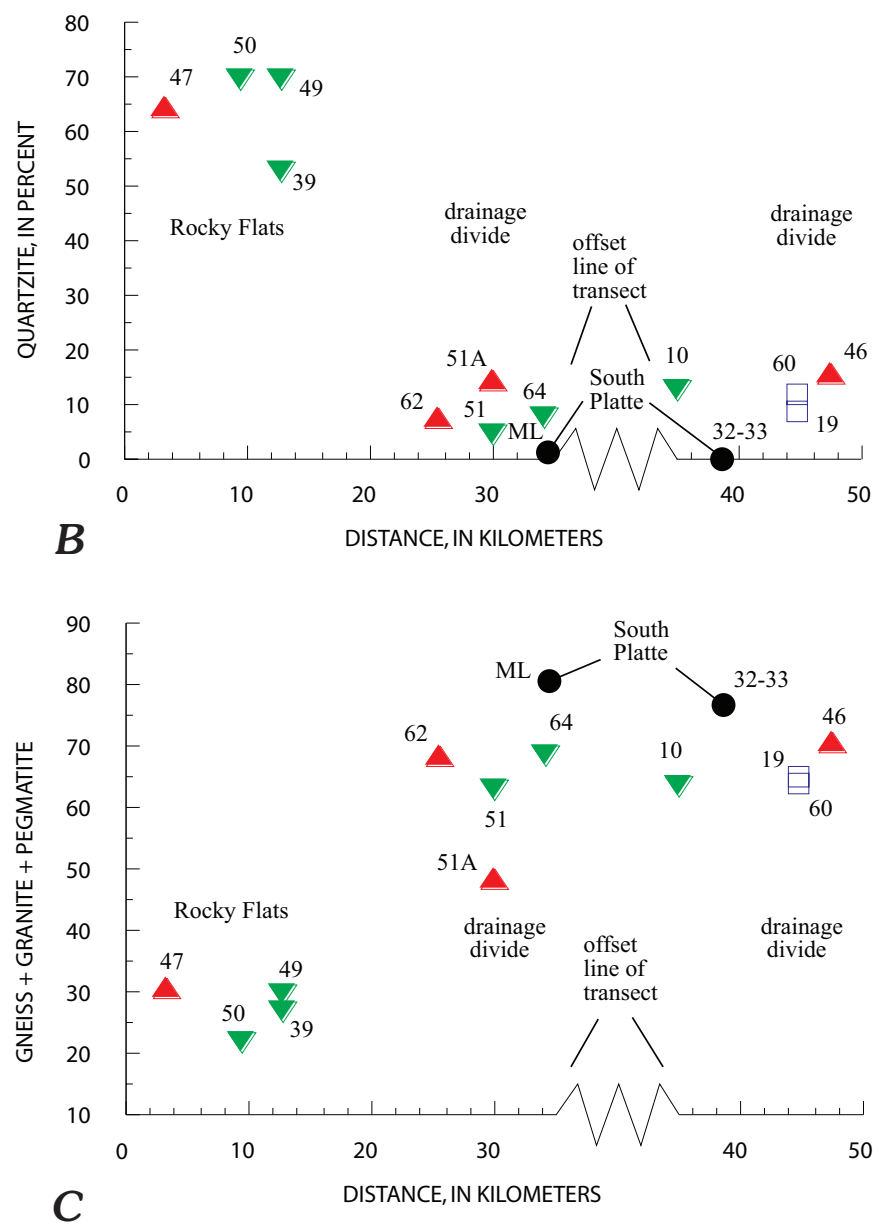

EXPLANATION

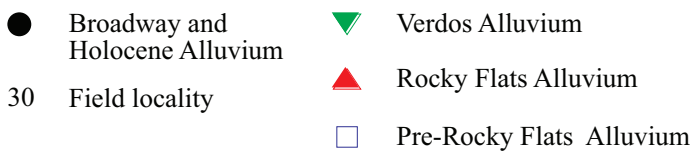

by boreholes (Smith and others, 1964; Robson, 1996). By late Pleistocene Broadway time, the South Platte River occupied its present position.

The much-reduced content of quartzite in latest Pleistocene Broadway and younger alluvium (average of about 1 percent, compared to an average of 10-11 percent in Verdos and Rocky Flats Alluvium on adjacent divides) in the South Platte River valley north of Denver requires explanation. This alluvium was brought from the south, upstream from the path of quartzite dispersion, and deposited in a valley incised largely in bedrock below the level of quartzite-bearing Verdos and Rocky Flats Alluvium (see fig. 4). The reduced quartzite content of the young valley fill reflects dilution by addition of gneiss, granite, and pegmatite (fig. 20C). In contrast, the abundance of vein quartz and volcanic clasts in Broadway and younger alluvium was maintained because these are available upstream. The abundance of vein quartz (average 6-8 percent) is not much less than in Verdos and older alluvium (average of 10-11 percent) on adjacent drainage divides. The retention of vein quartz but not quartzite in latest Pleistocene and Holocene alluvium indicates that weathering alone does not account for differences in quartzite content of alluvium of different ages.

A small area of higher-than-background abundance of vein quartz and quartzite is present along the Cache la Poudre River (fig. 18). As measured in 29 samples from eight gravel pits in late Pleistocene and Holocene gravel of the modern valley, Cache la Poudre gravel contains an average of 5 percent vein quartz and a little more than 7 percent quartzite. Among field localities, value ranges are 2-11.5 and 3-13 percent, respectively (table 2) (Langer and Lindsey, 1999). Vein quartz and quartzite may have been concentrated by recycling these resistant rocks from older alluvium. Comparison of quartz and quartzite content of two gravel units in the Cache la Poudre River valley suggests minor concentration in the upper unit (Langer and Lindsey, 1999).

\section{Roundness}

In the fluvial environment, roundness (the absence of sharp corners) of clasts is the product of abrasion during transport. The degree of roundness is a function of particle size, lithology (hardness), and distance of transport (Pettijohn, 1975; Potter and Pettijohn, 1963). Large particles round more quickly than smaller particles. By comparison of downstream regression-line slopes of roundness (Mills, 1979), angular clasts of soft rocks such as limestone become rounded after

Figure 20 (facing column). Transect from mouth of Coal Creek Canyon to Beebe Draw showing pebble lithology in alluvium of various ages. $A$, Map showing field sample localities; $B$, Plot showing percent of quartzite clasts; and $C$, Plot showing percent of gneiss + granite + pegmatite. Data for Verdos and older alluvium in table 3; data for Broadway and younger alluvium in Lindsey, Langer, and Shary (1998) and Lindsey and Shary (1997). 
Stratigraphy, Lithology, and Sedimentary Features of Quaternary Alluvial Deposits, S. Platte River and Tributaries, Colo.

traveling short distances, whereas clasts of hard lithologies such as quartz and quartzite require longer transport to become rounded. In streams of the Front Range, rounding began very near the source, perhaps aided by entrainment in floods of turbulent meltwater from retreating glaciers. Near the heads of glaciated valleys, rounded clasts of granitic and metamorphic rocks are common in glacial outwash and streambeds of reworked outwash. The various effects on roundness-including particle size, lithology, distance of transport and other complications-require a conservative approach to comparisons of average pebble roundness among streams. Relationships between lithology and roundness and associations with stream length and glaciofluvial provenance are explored in the Appendix to this report.

In the piedmont reaches of the South Platte River and its tributaries, average pebble roundness does not increase downstream in every case (fig. 21) because average roundness does not allow for the effects of downstream variation in lithologic proportions. In the examples studied here, exceptions to downstream increase in average roundness are accompanied by downstream changes in pebble lithology. For well-rounded gravel in the modern South Platte River between Denver and Fort Lupton, pebble roundness decreases as the proportion of pegmatite pebbles increases downstream (Lindsey and Shary, 1997). The destruction of large pegmatite clasts during transport has evidently produced smaller, angular pegmatite pebbles; pegmatite clasts tend to break along large, angular crystal boundaries. This explanation is supported by less-thanexpected frequencies of rounded pegmatite in a variety of clast populations (Appendix).

Pebble roundness may also decrease in response to recycling. Recycling of quartzite-rich Rocky Flats Alluvium at the head of Big Dry Creek led to a decrease in pebble roundness of Verdos Alluvium immediately downstream (table 1). In this case, the proportion of quartzite pebbles remained about the same. Evidently, some quartzite clasts in Rocky Flats Alluvium were broken during weathering, transport, and deposition in Verdos Alluvium.

Complex downstream trends in pebble roundness may result from contributions by tributary streams. For late Pleistocene and Holocene gravel of the Cache la Poudre River between Fort Collins and Greeley, pebble roundness decreases downstream to a point halfway between the two cities, then increases abruptly at Greeley (Langer and Lindsey, 1999). The downstream change cannot reflect variation in lithologic proportions because each major lithology follows the same trend. Where rounding decreases, it is accompanied by minor increases in abundance of vein quartz plus quartzite and some volcanic rocks, indicating additional sources, possibly from tributaries entering the Cache la Poudre from the north.

Among the major tributaries of the South Platte River that were investigated, pebble roundness values for Louviers and younger alluvium of Clear Creek, Boulder Creek, St. Vrain Creek, the Big Thompson River, and the Cache la Poudre River are in the same range as the South Platte River. Average pebble roundness exceeds 0.45 , even close to the mountain front (fig. 21). These streams have mountain reaches in the range of 30-80 km (much more in the case of the South Platte River), and they head in tributary valleys that were glaciated during Pleistocene time (Madole, Van Sistine, and Michael, 1998). Gravel deposited by all of these streams consists largely of gneiss, granitic rocks, and pegmatite.

Pebble roundness in alluvium of upper Big Dry Creek (derived from Coal Creek Canyon) and Ralston Creek is much lower than in alluvium deposited by major tributaries. Average roundness values are typically less than 0.40 (table 1), notwithstanding the great difference in lithology (quartzite versus gneiss and amphibolite) and, in Ralston Creek, age of alluvium (Verdos versus Piney Creek Alluvium). Coal Creek Canyon extends only $13 \mathrm{~km}$ into the mountains, and Ralston Creek extends only $21 \mathrm{~km}$. Pebbles in Louviers Alluvium of Bear Creek are poorly rounded and those in Louviers Alluvium of Lefthand Creek are intermediate in roundness, between those of Bear Creek and major streams. The length of mountain reaches of Lefthand Creek $(30 \mathrm{~km})$ and Bear Creek $(40 \mathrm{~km})$ are in the same range as the shortest streams with extensive glaciated headwater valleys, such as Boulder Creek and St. Vrain Creek. Lefthand Creek and Bear Creek do not have extensively glaciated headwater valleys. Thus, the availability of large volumes of glacial meltwater as well as the length of the mountain reach may have been important to rounding.

Pebble roundness in terrace gravel varies with distance from source and degree of recycling. Commonly, terrace gravel has been recycled from older conglomerate or gravel. Pebbles in near-source recycled gravel, such as that derived from the Denver Formation and the Green Mountain Conglomerate, for example, have low average roundness $(<0.4$, table 1). Nevertheless, even after only $3-5 \mathrm{~km}$ of transport, 34-46 percent of pebbles in Slocum and Verdos Alluvium south of Green Mountain have roundness values of $D$ (rounded) or E (well rounded). Pebbles derived from conglomerate on Green Mountain may have acquired some of their roundness during erosion and transport in Late Cretaceous and Paleocene time. Additionally, as clasts are moved farther from their source, the likelihood that they have been recycled (for example, from Rocky Flats to Verdos Alluvium) during Quaternary time increases. Downstream, in pre-Rocky Flats, Rocky Flats, and Verdos Alluvium located on divides east and west of the South Platte River, pebble roundness ranges from 0.4 to 0.5 (fig. 21, table 1). Pebble roundness in old alluvium may reflect long transport and recycling. The degree to which stream length and rounding by high-discharge glacial meltwater affected rounding in old alluvium is unknown.

\section{Clast Populations}

Lithology and roundness can be used together to characterize individual populations of clasts that have a distinct source and transport history (see Appendix). Clast populations are distinct for individual streams and drainage systems. Mixed populations may reveal joining of streams. 

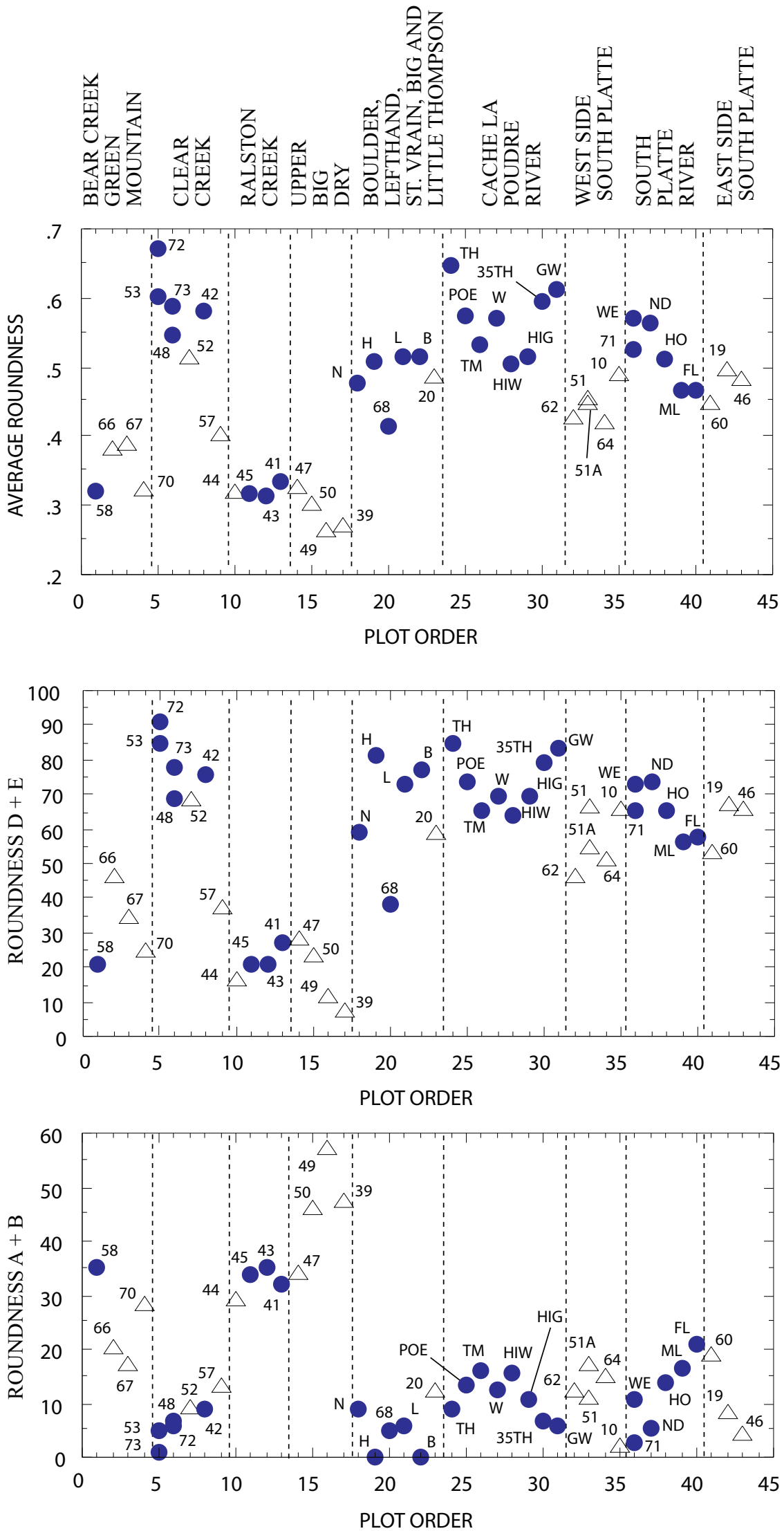

\section{EXPLANATION}

- Louviers or younger alluvium

$\triangle \quad$ Slocum and older alluvium

60 Field locality number or name
Figure 21. Pebble roundness in alluvium of the South Platte drainage basin east of the Front Range, Colorado. Each sample point represents one or more counts of 100 or more pebbles at one locality. Plot order for tributaries is from south to north; localities for each stream are plotted from upstream (left) to downstream (right); Holocene South Platte gravel plotted separately from ancestral South Platte gravel. Localities shown in fig. 3 . 
One of the most distinct clast populations is found in Rocky Flats Alluvium at Rocky Flats and in Verdos and younger alluvium derived from it on Upper Big Dry Creek. As described under "Dispersion Paths," this gravel is dominated by subangular to subrounded clasts of metaquartzite derived from Coal Creek Canyon. Many clasts still show edges and corners inherited from the intersection of bedding and fractures in the source terrane. Foliated and layered quartzo-feldspathic gneiss, commonly containing quartzite laminae, comprise 16-21 percent of the clasts (table 1). Pegmatite clasts, the interiors of which commonly show effects of deformation and are therefore derived from gneiss terrane, comprise a few percent. Only minor amounts of nonfoliated, medium-grained granitic rock from the Mesoproterozoic Boulder Creek Granodiorite (Gable, 2000), exposed at the head of Coal Creek Canyon, are present in alluvium at Rocky Flats. This may due in part to widespread foliation of the granodiorite and associated quartz monzonite (Wells, 1967), which would cause clasts to be identified as gneiss. Whether they are classified as gneiss or granitic rocks, only foliated rocks having some component of quartzite and pegmatite with large crystals of quartz survived transport and weathering to appear in the counts. Also, weathering after deposition undoubtedly affected the abundance of gneiss and granite in the counts (Laughon, 1963).

The clast population of Verdos Alluvium (field locality 44, table 1) along Ralston Creek (fig. 10) is nearly identical in lithology and roundness to the much younger Piney Creek Alluvium of Ralston Creek (localities 41, 43 and 45, table 1). Both contain abundant subangular and subrounded clasts of gneiss and amphibolite, indicating derivation from the head of Ralston Creek. Cobbles and boulders of volcanic rock were found only in Verdos Alluvium immediately downstream from the Ralston dike (mapped by Van Horn, 1972). Metaquartzite is a minor component, indicating that Ralston Creek and its tributaries were already eroding the quartzite-rich gravel of Rocky Flats during Verdos time. Significantly, no volcanic rock was found in Ralston Creek, even though the stream skirts the north side of the Ralston Creek dike (see map by Van Horn, 1972). The similarity in lithology and roundness of gravels of widely varying ages indicates that Ralston Creek has drained the same source for more than $600 \mathrm{ka}$.

The clast population in gravel assigned to Rocky Flats Alluvium (Lindvall, 1979b) on a hilltop at 72nd Avenue and Wadsworth Boulevard in Arvada (locality 57, table 1) was probably deposited by ancestral Clear Creek. Clasts of Table Mountain Shoshonite (porphyritic latite, volcanic rocks in table 1) were derived from North and South Table Mountain. Abundance of mafic rocks is closest to that of Ralston Creek, suggesting the possibility that the locality lies below the confluence of ancestral Ralston Creek and Clear Creek. Comparing alluvium of all ages, the proportion of granite is intermediate between that of Clear Creek and Ralston Creek, and the proportion of gneiss and pegmatite is consistent with both streams. Roundness (average roundness is 0.403 , table 1) is noticeably higher than Ralston Creek. All of these characteristics suggest a blending of Clear Creek and Ralston Creek gravel. However, the clast population at locality 57 does not contain quartzite, suggesting that (1) the locality lay above the confluence of the two streams or (2) the alluvium at locality 57 predates the quartzite-rich alluvium of Rocky Flats.

Downstream and northeast from locality 57, on the divide between Big Dry Creek and the South Platte River, gravel of Rocky Flats and Verdos Alluvium reflects mixing of clast populations (table 1). In addition to minor quantities of amphibolite, volcanic rock, vein quartz, and quartzite-all of which testify to a mixed source - this gravel contains abundant moderately rounded gneiss, granite, and pegmatite. As discussed previously, this gravel records the crossing of clast dispersion paths from the Green Mountain-Table Mountain area (volcanic rocks and vein quartz) and Rocky Flats (metaquartzite).

\section{Sedimentary Features}

Sedimentary features described here, which include both bounding surfaces and bedforms, are all from alluvium of the South Platte River valley and tributaries that arise in the Front Range. Features were not examined in alluvium of streams that arise on the Colorado Piedmont, and our observations, made on deposits of streams arising in the mountains, may not be applicable to the former. In contrast to alluvium of streams emanating from the mountains, alluvium deposited by streams arising on the piedmont may differ in grain size and structure. Scott (1963) describes some structures in pebbly alluvium along major streams and in silty alluvium along minor streams in the Louviers. Farther from the mountains, McKee and others (1967) describe the sedimentary features of recent sandy deposits of a single flood on Bijou Creek, a tributary of the South Platte River east of Denver.

Sedimentary features were examined to ascertain the depositional processes of gravel in the modern valleys (flood plains and low terraces) of the South Platte and Cache la Poudre Rivers. Because three or four stratigraphic units, of late Pleistocene and Holocene age, have been identified in each valley, sedimentary features in each unit are described separately. Observations of gravel in the South Platte River valley were made in three pits north of Denver and, in the Cache la Poudre River valley, eight pits between Greeley and immediately upstream from Fort Collins (fig. 3). Descriptions and interpretations from earlier reports (Lindsey, Langer, Cummings, and Shary, 1998; Langer and Lindsey, 1999) are revised and summarized here.

Sedimentary features of Pleistocene terrace gravel (Louviers and Verdos Alluvium) and the Rocky Flats Alluvium were examined in pits. These exposures represent mountainfront reaches of tributaries of the South Platte River. One exposure, of Rocky Flats Alluvium in Arvada, is from a road cut on a drainage divide; it represents a tributary downstream from the mountain front. 


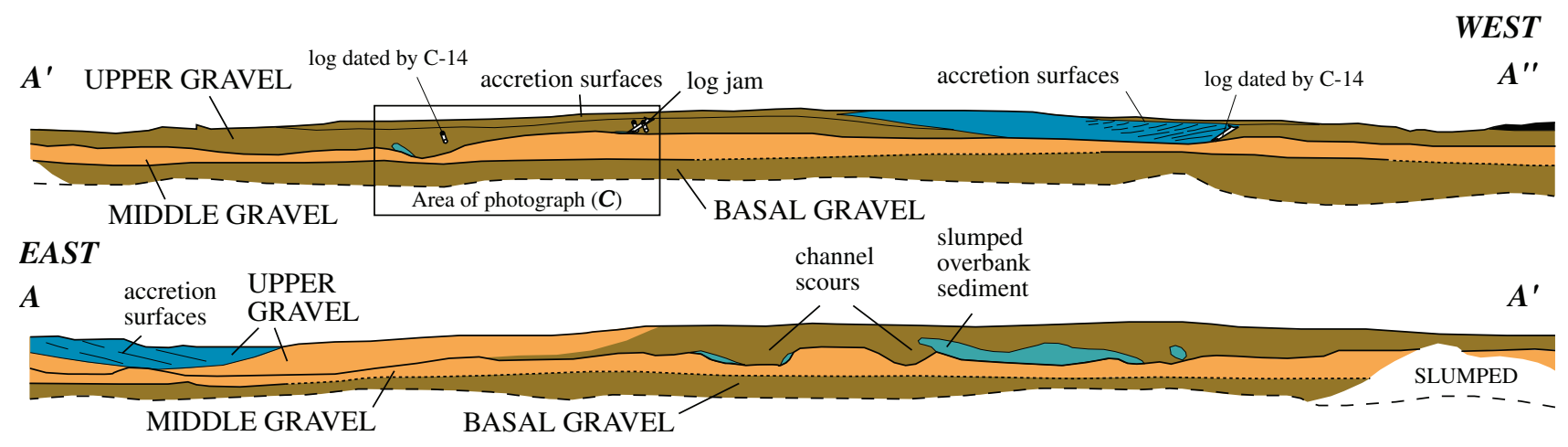

A

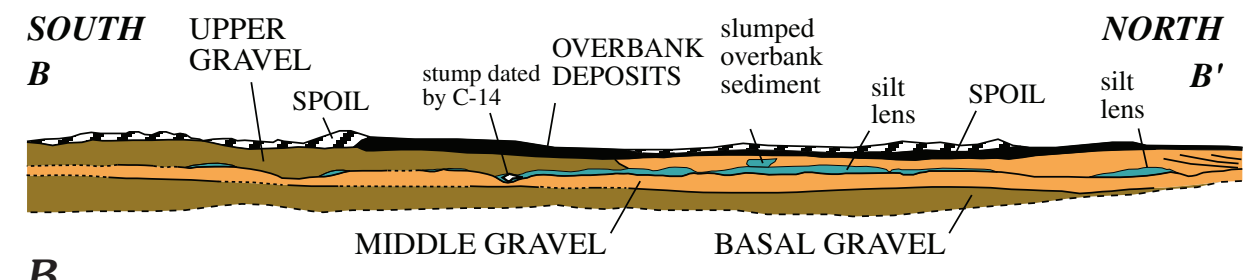

$B$

\section{EXPLANATION}

Vertical exaggeration $1.5 \times$

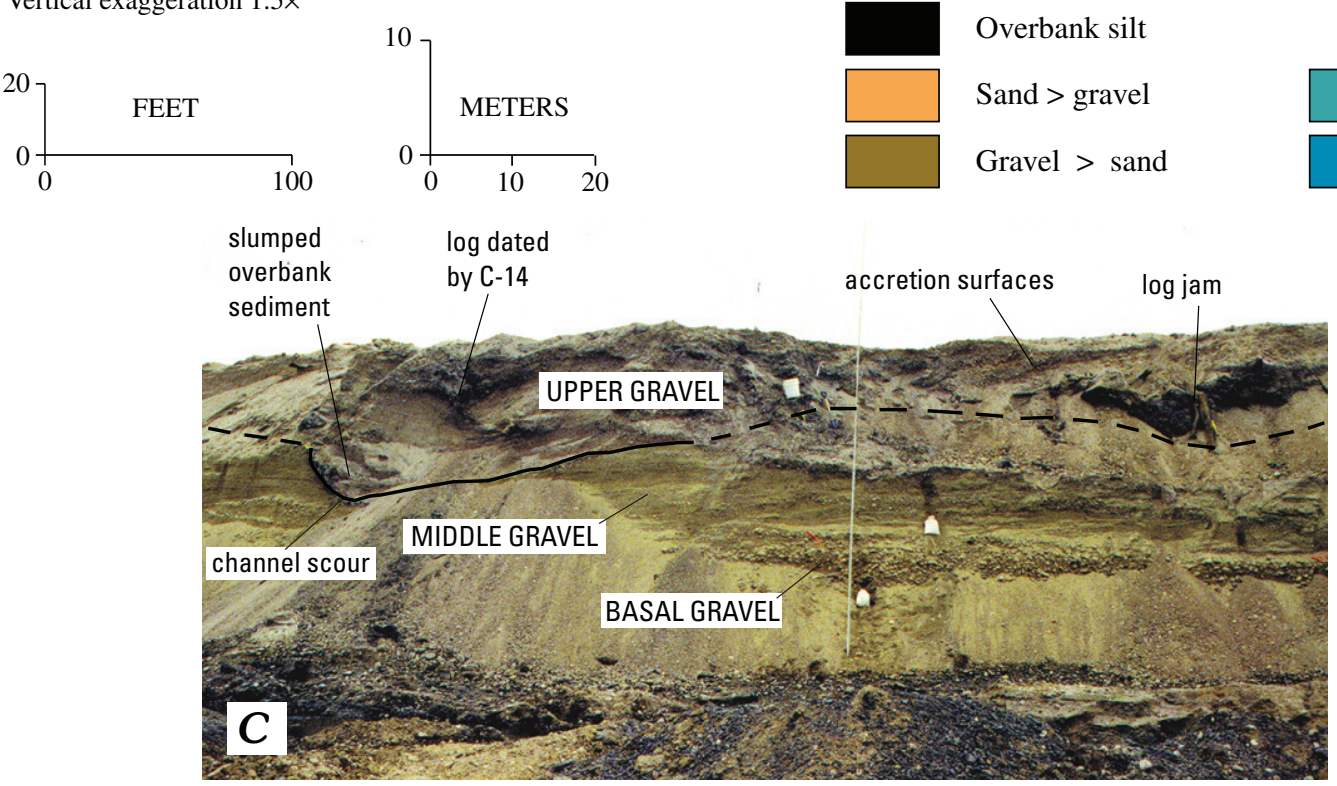

Figure 22. Sketches and photograph of pit walls at the Howe gravel pit, South Platte River, showing three gravel units and occurrence of sedimentary features discussed in text (from Lindsey, Langer, Cummings, and Shary, 1998). $A$, Connected sections perpendicular to valley, looking upstream; $B$, section parallel to valley, downstream to right. Dashed contacts, exact position obscured by sloughing of pit walls; $C$, photograph of portion of $A^{\prime}$ - $A^{\prime \prime}$ near site of left-most log dated by carbon 14, upper gravel, middle sandy gravel, and basal gravel. Channel fill below log contains inclined slab of silt and clay interpreted as slumped overbank sediment; log jam in upper gravel to right. Pit face about $6 \mathrm{~m}$ high.

\section{South Platte River Valley North of Denver}

Three units of gravel and one of overbank deposits (fig. 22) underlie the modern valley of the South Platte north of Denver. From bottom to top, these units are (1) a coarse basal gravel (1-2.5 $\mathrm{m}$ thick), (2) a middle sandy gravel (1-4 m thick), (3) an upper gravel (1-5 m thick), and (4) overbank deposits of sand, silt, and clay (commonly 1-1.5 m thick). As discussed under "Stratigraphy," the bottom unit is late Pleistocene in age, the middle gravel is probably Holocene to late Pleistocene in age, and the top two units are Holocene in age. The bottom contact of overbank deposits is sharp and locally erosional; the bottoms of the upper and basal gravel units are erosional disconformities; the bottom of the middle unit ranges from gradational to sharp. No intact overbank deposits were observed on the middle and basal gravel units. 
The basal gravel (fig. 22) consists mainly of clast-supported pebble and cobble gravel and much interstitial sand. The basal gravel is much coarser than the middle and upper gravel units (fig. 5). Except for diffuse horizontal bedding, closely packed clast imbrication and, locally, crossbedded sand lenses, sedimentary structures are scarce. The base of the gravel, which overlies the Denver Formation and marks the base of the valley fill, reveals broad, shallow scours.

The middle gravel is composed of sandy gravel, much of it containing complex associations of horizontal bedding and planar and trough crossbedding (fig. 23). Although the base of the middle gravel contains local scour features, an erosional disconformity has not been observed. The middle gravel appears mainly to record aggradation (vertical accretion). Trough crossbedding, much of it less than $15 \mathrm{~cm}$ in amplitude and interpreted as having formed by small dunes migrating over bars during high discharge, is abundant and widespread. Similar structures have been observed on the tops of various types of in-channel and bank-attached bars in the modern South Platte River (Crowley, 1983).

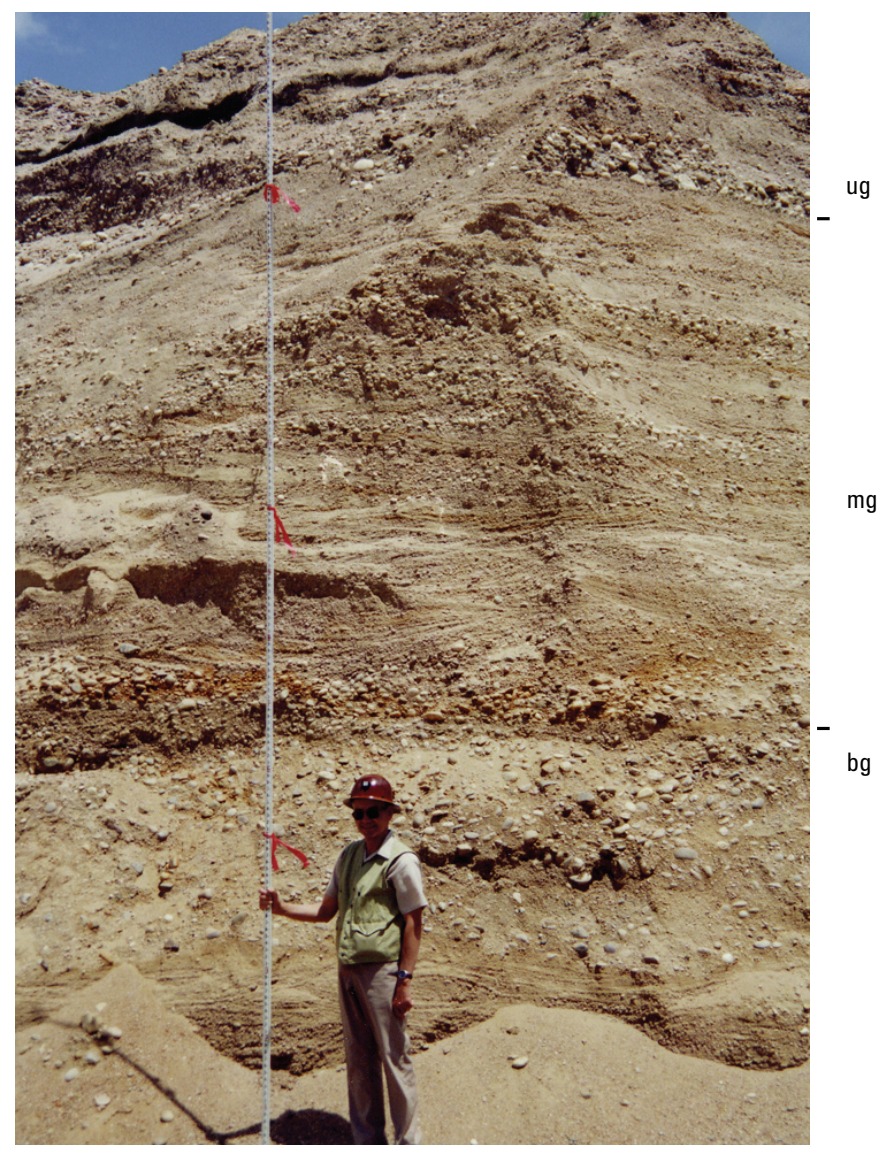

Figure 23. Photograph of gravel units and sedimentary features, North Dahlia pit. Trough crossbedding, formed by curve-crested dunes, is exposed in middle sandy gravel $(\mathrm{mg})$. Basal gravel (bg) is poorly bedded, with sandy layer at bottom. Upper gravel (ug) is exposed at top. The pit face is approximately perpendicular to current flow, which was toward the pit wall.
Lenses of structureless silt are locally abundant in the middle gravel at the Mann Lake pit (ML, fig. 3) and the lower part of the upper gravel in the Howe pit (HP, fig. 3). The grain size of these lenses was first designated "clay" (Lindsey, Taggart, and Meeker, 1998), but laboratory analyses reveal abundant silt and subordinate fine sand and clay. ${ }^{6}$ The lenses are massive except at a few places near the base, where faint laminae fill erosional scours in underlying gravel. Both tops and bottoms of the lenses are sharp and, in some places, erosional. A wood stump fragment buried in one lens at the base of the upper gravel was transported to its resting site, as indicated by its broken condition and inclined position. Silt lenses do not contain profiles of well-drained Holocene soils (e.g., Piney Creek Alluvium of Machette, 1977), but chemical analyses reveal small concentrations of organic carbon at their tops, suggesting that they may have once sustained vegetation. Their chemical composition indicates a weathered source comparable to Front Range soils, overbank deposits, and loess (Lindsey, Taggart, and Meeker, 1998). Massive structure and presence of abundant silt are compatible with either deposition by wind (Pye, 1987) or from suspended load after floodwater subsided. The inclined stump fragment indicates deposition from water.

As exposed in the faces of gravel pits, silt lenses range to $30 \mathrm{~m}$ in long dimension and $0.75 \mathrm{~m}$ in thickness (Lindsey, Taggart, and Meeker, 1998). Measurements represent lenses exposed on pit faces oriented approximately parallel as well as perpendicular to the valley. All are in contact with deposits of gravel bars. Poorly drained deposits of silt and clay, of approximately the same dimensions, have been observed filling the downstream ends of secondary channels on bank-attached bars of the modern South Platte, and this environment was the site of deposition favored after initial study (Lindsey, Taggart, and Meeker, 1998). Other possible depositional sites, such as abandoned channel meanders and swampy areas on flood plains, appear unlikely. The lenses have high width/thickness ratios that are not comparable to dimensions of abandoned channels. They are only interleaved with deposits of gravel bars and not with stratified overbank sediment.

The upper gravel unit contains much evidence of deposition by lateral cutting and filling like that in the South Platte River today. Clast-supported, stratified pebble gravel with sand in interstices dominates the upper gravel, but silt (described above) and sand lenses are locally abundant (figs. 22A, 22B). Sand lenses range up to $30 \mathrm{~m}$ in exposed length and about 2-3 $\mathrm{m}$ in thickness and, in some places, comprise the entire thickness of the upper gravel. The base of the upper gravel is an erosional disconformity; the gravel fills small scours and channels eroded into the underlying middle sandy gravel (fig. $22 C$ ). At one pit, a 5-m-deep channel filled with gravel was observed. Preserved depositional features range from those

\footnotetext{
${ }^{6}$ Average of four samples, determined by laser particle size analyzer by E.M. Fisher, U.S. Geological Survey, was 25 percent sand, 53 percent silt, and 22 percent clay, reported as volume percent.
} 
formed in channels by scour and fill (scour lags and bars) to those formed on bar sides (horizontal to inclined laminae separated by reactivation surfaces) and tops (ripple cross-lamination and small dune crossbedding).

At the Howe pit (HP, fig. 3), near 112th Ave and Brighton Boulevard, between Commerce City and Brighton, the upper gravel contains abundant intraclasts and distorted slabs, measuring from a few centimeters to $12 \mathrm{~m}$ in long dimension, of silt and clay (figs. 22A, 22C). The largest slabs rest in inclined position on scours at the base of the upper gravel. They probably represent overbank sediment that was undercut and caved by the river channel, then incorporated into gravel. Most erosion of banks takes place during flooding, although bank caving at the outer bend of meanders may occur at low to moderate flow, and soil conditions such as wetting and drying may induce gravity failure independent of flow stage (C.R. Thorne, in Simons and Li, 1982). The stratified nature of present-day banks along the South Platte, with overbank sediment resting on porous gravel, also promotes bank erosion and caving. The slabs of overbank sediment are evidence that past stream banks along the South Platte were similarly stratified.

Intraclasts of organic-rich silt occur with concentrations of cottonwood logs in sandy bar deposits of the upper gravel unit (fig. 22A). Small masses of rootlet-bound silt, logs, and other debris are commonly stranded on the sides and tops of bars after floods in the modern river. Such masses (intraclasts) and logs were evidently buried in the upper gravel during subsequent floods. Although most conspicuous at the Howe pit, both intraclasts and logs were observed in the upper gravel at nearby pits.
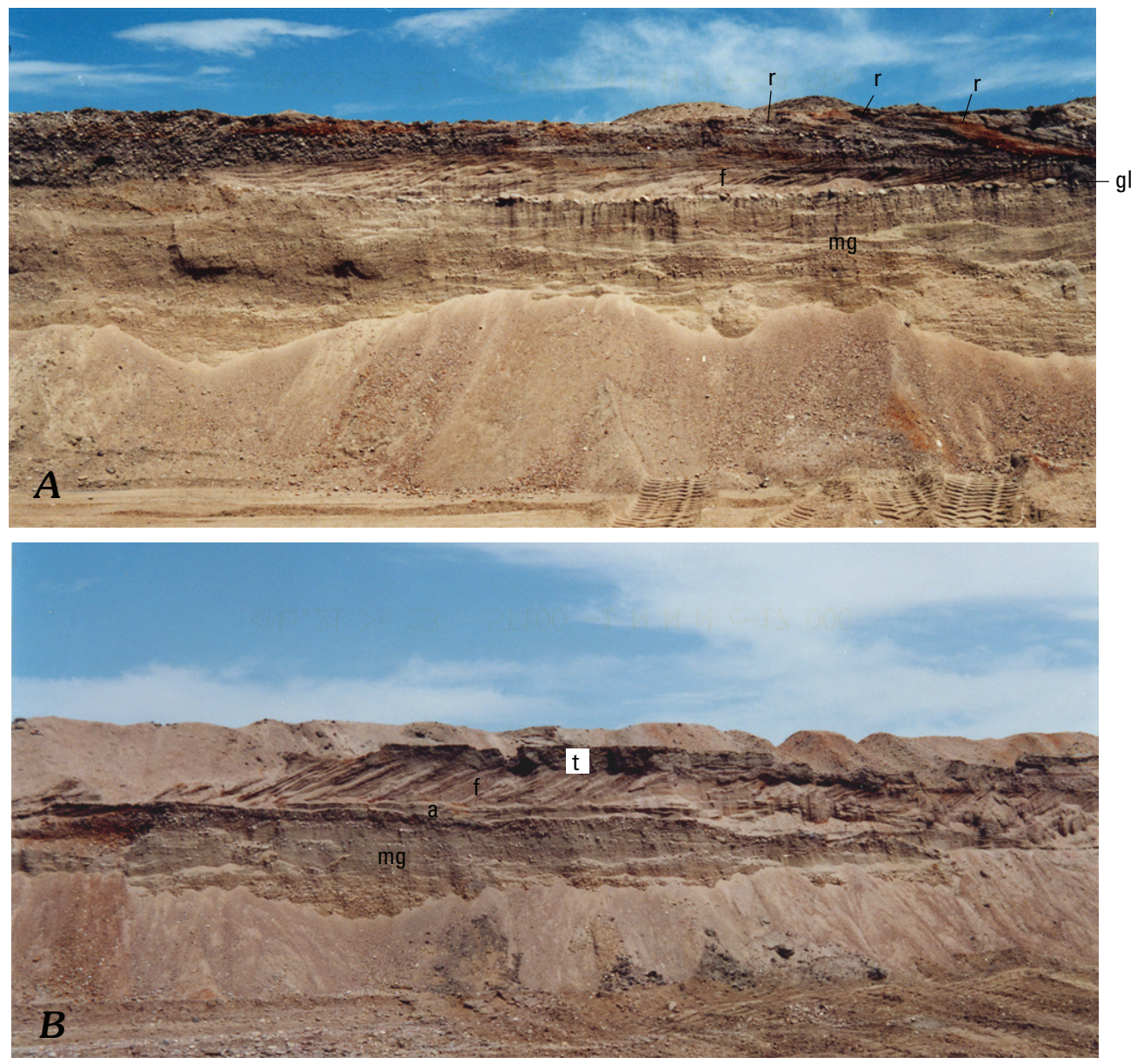

Figure 24. Photographs of channel and bar features in the upper gravel, North Dahlia pit, South Platte River, near 89th Ave. and Holly Street. Pit walls are oriented parallel to valley trend; downstream direction is to left. $A$, Gravel lag ( $\mathrm{gl}$ ) composed of a single layer of pebbles and cobbles marks the base of a shallow channel eroded into the middle gravel. Sand and gravel above the lag belongs to the upper gravel. A thin interval of foreset laminae (f) marks a migrating bar slip face immediately above the lag. These grade into low-angle accretion laminae to the left. Above foresets (right side) are horizontal topset laminae overlain by pebbly sand lenses, dipping to right, with low angle, concave-up accretion laminae separated by reactivation surfaces ( $r$ ). Top left, gravel filling channel cut in underlying bar and channel complex truncates pebble lag layer. Exposed section is about $4 \mathrm{~m}$ in height. $B$, Foreset laminae (f) of sand and gravel in the upper gravel, formed by avalanching of sand and gravel down the slip face of large gravel bar. Thin apron laminae (a) and thicker topset laminae (t) bound the foresets. Below the apron laminae, a thin lag of horizontally bedded gravel marks the base of the upper gravel. Foreset interval is about $2 \mathrm{~m}$ in height. Also shown $(A$ and $B$ ): middle sandy gravel $(\mathrm{mg})$ exposed in lower half of pit face, contains complex association of dish-shaped scours and horizontal bedding, probably a combination of channel and bar structures. 
Thin lags of pebbles and cobbles form armored surfaces on channel erosion surfaces (fig. 24A). Some lags are only one clast thick and rest on concave-up surfaces that extend laterally as much as $30 \mathrm{~m}$; they can only have formed by removal of fines from bottoms of channels during periods of normal to rising flow. In the example shown (fig. 24A), the lag is overlain by bar deposits, described next.

Structures interpreted as having formed on gravel bars are common in the upper gravel unit (fig. 24). In the upper unit, deposits of sandy gravel bars contain laminae inclined at low angles to horizontal and mostly concave up; these laminae are interpreted as accretionary. Small, disconformable scours (reactivation surfaces) separate sets of conformable accretion laminae (fig. 24A); these surfaces probably form during fluctuations in discharge or channel position (Willis, 1993). Exposures of gravel beds oriented parallel to the valley also contain medium- and large-scale (as much $2 \mathrm{~m}$ in height) planar crossbed sets (fig. 24B), interpreted to have formed by downstream migration of bar slipfaces. Individual foreset laminae of sand and pebbles are uniformly inclined at angles approaching $30^{\circ}$ and are tangential with underlying beds. The underlying beds are horizontally laminated and cross-laminated sand, interpreted as apron laminae (terminology of Crowley, 1983) of bars. The foreset laminae are disconformably overlain by thin beds of horizontally laminated and cross-laminated sand, interpreted as topset laminae of bars (fig. 24B). The sequence of apron, foreset, and topset laminae is identical with the structure of the in-channel and bank-attached macroforms (bars) described in the Platte and South Platte Rivers by Crowley (1983).

The upper gravel is overlain by fine-grained sediment approximately $1-1.5 \mathrm{~m}$ in thickness, commonly referred to "post-Piney Creek Alluvium" on many geologic maps (e.g., Lindvall, 1979a), but here called "overbank deposits." Some South Platte overbank deposits contain weak humic horizons and thin layers of interbedded granule gravel and sand, but most consist of laminated silt and clay (Lindsey, Langer, Cummings, and Shary, 1998). Sand and granule-gravel layers contain intervals of ripple cross-lamination and crossbedding. Given the young age of the underlying (upper) gravel unit, some overbank deposits probably represent historic floods.

\section{Cache la Poudre River Valley}

As discussed under "Stratigraphy," the modern valley of the Cache la Poudre River contains two gravel units (a lower unit, 1.5-2.5 $\mathrm{m}$ thick, and an upper unit, 1-5 m thick) and overbank deposits of sand, silt, and clay (1-1.5 m thick) (Langer and Lindsey, 1999). The lower and upper gravel units were distinguished in valley fill below Fort Collins. The contact below the two gravel units is an erosional disconformity. The contact between overbank deposits and the upper gravel is sharp. As with overbank deposits of the South Platte, weak humic horizons typical of post-Piney Creek Alluvium are evident but other soil zonation is not visible.
At the Taft Hill pit (TH, fig. 3), upstream from Fort Collins where two stratigraphic units cannot be distinguished in the gravel, the gravel is very coarse (pebble and cobble size, but boulders are common). Gravel is weakly bedded, with beds defined by varying clast size, layers of imbricate clasts, and sparse sandy lenses (fig. 25). Open-work texture was not seen; sand fills interstices between clasts. Such bimodal deposits of horizontally bedded gravel, lacking foresets, may form initially as diffuse gravel sheets that move down-channel during high discharge (Hein and Walker, 1977). After initial deposition, selective erosion and redeposition modify gravel fabric and texture as currents scour gravel sheets. In clear water flow when no sediment is added from upstream, large clasts are tilted to form imbrication, rotated so that their long axes are perpendicular to currents, and sometimes transported farther downstream (Sutherland, 1987). Small clasts lodge on the upstream side of large imbricate clasts, and sand accumulates on the downstream side. The result is a static armor layer of imbricate clasts. This reorganization of gravel fabric and textures has been demonstrated by laboratory flume studies (summarized by Sutherland, 1987). Scour and reorganization of gravel on channel bottoms and gravel sheets is the probable origin of much horizontally bedded, imbricated gravel of the Cache la Poudre River.

Less commonly, beds of imbricated gravel are interbedded with nearly horizontal lenses of sand; this association is interpreted as a bar-top sequence (fig. 25). Individual pebbles in thin, gently dipping layers of Cache La Poudre gravel are imbricated, much as they are on gravel-bar lobes of present-day streams (e.g., Church and others, 1987). Such small

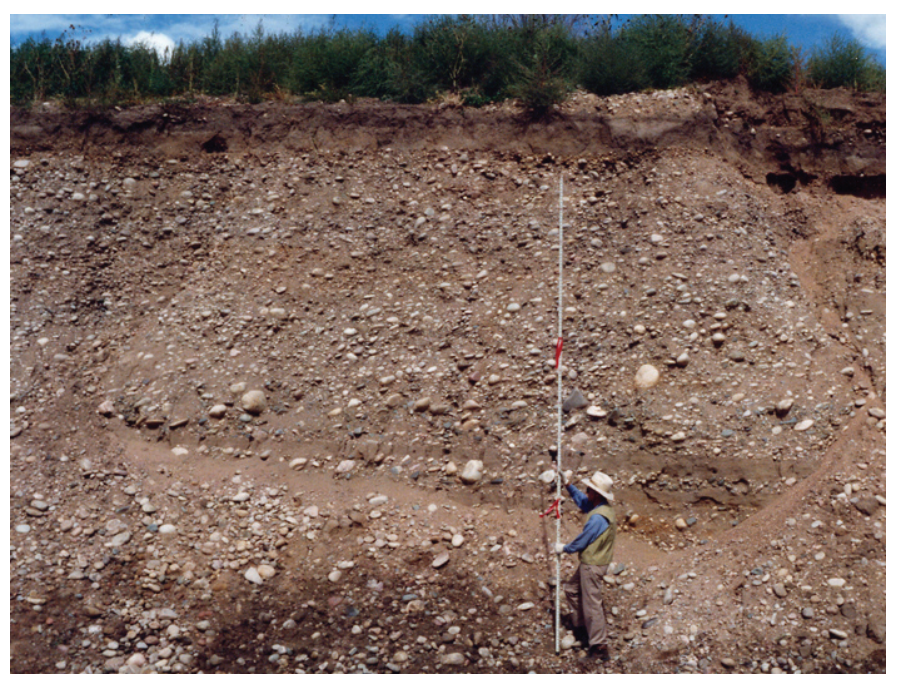

Figure 25. Photograph of sedimentary features in undivided gravel at the Taft Hill gravel pit, Cache la Poudre River west of Fort Collins, showing crudely layered pebble and cobble gravel with imbrication and lens containing sand and imbricated pebble layers (level with man's head), interpreted as a bar-top deposit (bottom of bar covered by debris). Overbank deposits and soil at top of pit wall. 
accretionary lobes (called "bar units" by Bluck, 1982, who describes them in detail) cover modern river bars. With each subsequent flow, the surface fabric and texture of individual lobes is reorganized to form imbrication and armoring, much like the process that forms imbrication and armoring on gravel channel bottoms. In the Cache la Poudre gravel, layers of imbricate clasts are coarsest at their upstream ends, a characteristic of individual lobes on gravel-bar tops (Bluck, 1982).

The top of the lower gravel unit has been extensively scoured at many places, with the upper gravel resting on truncated channel and bar forms of the lower gravel (fig. 26A). Both horizontal and inclined $\left(<10^{\circ}\right)$ layers of clasts were observed in gravel at the Windsor pit (HIW, fig. 3), located midway between Fort Collins and Greeley, and at the 25th Street pit (GW, fig. 3) in Greeley (see photographs in Langer and Lindsey, 1999). At the latter locality, the lower gravel unit contains lenses of sand and gravel separated by scour (reactivation) surfaces (fig. 26A). The basal parts of sand lenses are gently inclined and interfinger with gravel.

Locally, the upper gravel unit contains irregular lenses and intraclasts of dark organic-rich silt ranging from about 4-5 $\mathrm{cm}$ to $1 \mathrm{~m}$ across (fig. 26B). At the POE gravel pit (POE, fig. 3) downstream from Fort Collins, the lenses and intraclasts are concentrated in channel scours at the base of the upper unit.
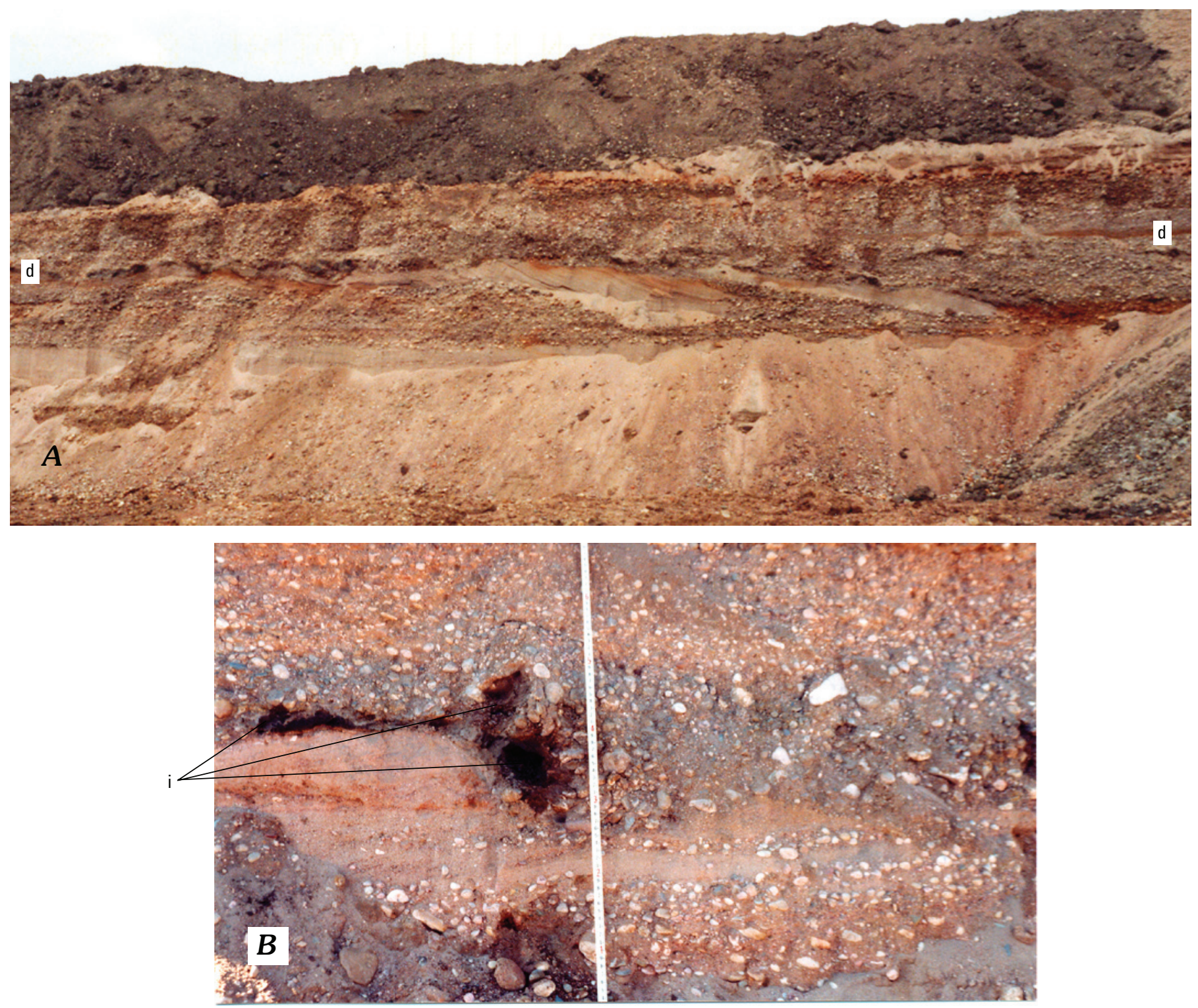

Figure 26. Photographs of sedimentary features in upper and lower gravel units, Cache la Poudre River. $A$, Upper gravel resting on erosional disconformity (d), truncates features in lower gravel unit, 25th Street pit. In right half of picture, the lower gravel contains a sequence of accretion deposits separated by scour (reactivation) surfaces. Exposed section is about $3 \mathrm{~m}$ high. $B$, Detail of erosional disconformity between upper gravel and lower gravel, POE pit. Imbrication and crossbedding in both gravel units indicates flow from right to left; organic-rich silt lens and intraclasts (i) rest on disconformity. Eroded top of lower gravel unit has sand lens with downstream fining, interpreted as bar top. Exposed section is about $2 \mathrm{~m}$ high. 
Stratigraphy, Lithology, and Sedimentary Features of Quaternary Alluvial Deposits, S. Platte River and Tributaries, Colo.

The silt may represent remains of overbank deposits that were undercut and caved by floodwaters, much in the same manner as those described in the upper gravel unit of the South Platte River.

Both gravel units of the Cache la Poudre River valley represent channel and bar deposits of a gravel-bed river. The overall close match in accretionary bar structure and particle size (fig. 8) between the two units suggests that, given the likelihood of identical drainage basins, the depositional processes and competency of the two streams may have been similar. Silt lenses and intraclasts above the scoured base of the upper gravel, interpreted as remains of overbank deposits, are evidence for earlier flood plains. The sharp, scoured base of the upper gravel marks the maximum depth of erosion of gravel as the stream cut laterally across the valley.

\section{Tributary Valleys Near the Mountain Front}

\section{Clear Creek}

Louviers Alluvium was examined in terrace fill exposed in the highwall of an old gravel pit along the north side of Clear Creek, located southeast of the corner of 44th and McIntyre Streets about $4 \mathrm{~km}$ east of Golden (field locality 72, fig. 3, and near the line of section $Z-Z^{\prime}$, fig. 12). The highwall is oriented parallel to the present course of Clear Creek and its valley fill of Broadway Alluvium. A Louviers soil profile has been described from this locality (Machette and others, 1976).

The exposure of Louviers Alluvium consists of a 6-m interval of stratified pebble and cobble gravel that is continuous for more than $200 \mathrm{~m}$ in the downstream direction. Although the gravel does not represent a single depositional event, only sparse accretionary lenses and erosional scours interrupt the homogeneity of the gravel (fig. 27A). Individual stratification features are not continuous in the downstream direction. A few thin $(<1 \mathrm{~m})$ lenses of sand, granule- and small-pebble gravel extend downstream for distances of 10 $\mathrm{m}$ or less. Variation in pebble size, packing, and degree of imbrication also defines faint lenses and layers, but overall, clast size is uniform from top to bottom. We did not see outsize boulders much larger than $0.3 \mathrm{~m}$; Baker (1974) measured average long dimensions of ten largest clasts at $0.310-0.355 \mathrm{~m}$ in Louviers Alluvium near here. Most of the gravel matrix is sand.

Lenticular structures in the Louviers gravel of Clear Creek define segments of large in-channel bedforms interpreted as bars (fig. 27A). Boundaries between channel bedforms are defined by abrupt transitions in grain size, by sand lenses, and by scours. Boundaries defined by abrupt transitions from pebble to cobble size rise over downstream distances of $10+\mathrm{m}$. Sand and granule lenses are situated near the tops and downstream ends of these boundaries. In some cases, lenses appear to be arranged in a downstream-rising, en echelon pattern, suggesting both downstream and vertical accretion (fig. 27A). At their downstream ends, sand lenses have sharp contacts with underlying gravel, but in the upstream direction, they interfinger with gravel (fig. 27B). Tops of lenses are truncated by scour surfaces, which in turn are overlain by gravel of the next-formed bar or bar element. Clusters and armor layers of coarse imbricate pebbles and cobbles rest on some scour surfaces, as well as on gravel surfaces beneath sand lenses. These form on both channel bottoms and bar tops of gravel-bed streams (Brayshaw, 1984; Reid and others, 1992, and discussion by C. de Jong).

Most sand lenses contain low-angle cross-laminae, defined by varying particle size. Where lenses rise in the downstream direction, laminae dip gently upstream or are broadly concave-up (fig. 27B). Some sand lenses interfinger with gravel upstream over distances as short as $3 \mathrm{~m}$ (fig. 27B). A few sand lenses contain foreset laminae that probably represent small slipfaces at the downstream ends of bar tops. Field and flume studies of mid-channel bars show that fine sediment is routed around bar margins and accumulates at the downstream ends of bars (Ashworth and others, 1992). The sand lenses described here are so interpreted.

Some of the above-described sedimentary features have been described in shallow braided gravel-bed rivers (Miall, 1996). Complex deposits of lenticular gravel and sand with evidence of typical bar-top features and local scours are interpreted as aggradation by stacking and amalgamation of successively deposited and eroded bars (Smith, 1985). The relatively well sorted nature of Louviers gravel along Clear Creek, compared to the Louviers gravel of Bear Creek described next, indicates that aggradation was accompanied by considerable channel scour and winnowing. From estimates of channel cross section, slope, and mean maximum clast size, Baker (1974) calculated flood discharges of an order of magnitude greater than discharges of historic floods on Clear Creek during deposition of Broadway, Louviers, and Slocum Alluvium. Baker (1974) reasoned that only floods of glacial meltwater could have produced such high discharge. The evidence presented here, for stacked-bar structure of the Louviers Alluvium, is consistent with deposition by repeated high-discharge flows.

Subsequent paleohydraulic analysis by Costa (1983) and observations in the aftermath of floods (Shroba and others, 1979) showed that large flash floods in mountain streams are capable of transporting large boulders. Flash-flood deposits, however, differ in texture and structure from the Louviers Alluvium of Clear Creek. They are described next.

\section{Bear Creek}

A second exposure of Louviers Alluvium was examined in an abandoned gravel pit on the south side of Bear Creek, immediately across the creek from the entrance to Bear Creek Lake Park, and approximately $1.5 \mathrm{~km}$ east of Morrison (field locality 58, fig. 3). The gravel on Bear Creek was mapped as Louviers by Scott (1972) and has a calcareous soil horizon that resembles the Louviers of Clear Creek. The exposure of 


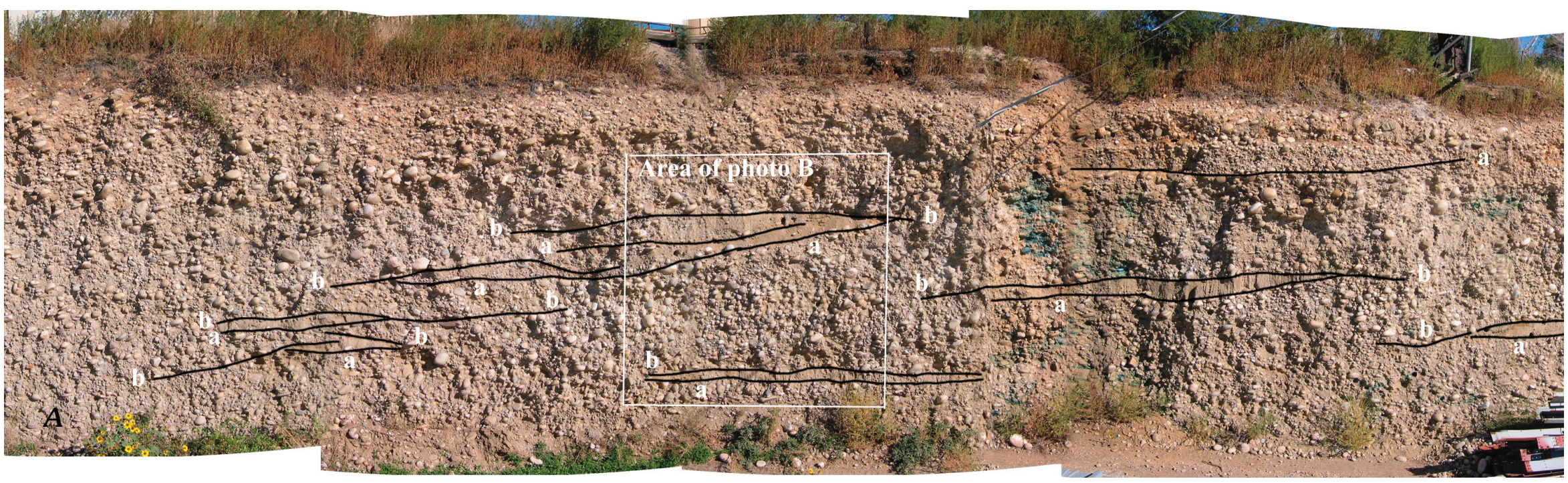

Figure 27. Photographs of stacked gravel bars in pit face in Louviers Alluvium, Clear Creek (field locality 72, fig. 3). A, Entire interval of gravel with lenses of pebbly sand that define breaks in deposition, interpreted as tops of stacked, intersecting bars; note rising level of en echelon sand lenses and surfaces from left to right (downstream), convex-up form of bar-top surfaces (b), accretion surfaces below sand lenses (a), and downstream erosiona truncation of sand lenses; exposed section about $6 \mathrm{~m}$ in height; $B$, Detail of downstream end of upper sand lens, located right center of $A$, showing downstream fining (df), upstream inclination (ui), and downstream truncation of lens (dt); underlying gravel displays strongly imbricated clasts and sand lens of underlying bar top. Small scale in center of photograph shows divisions in inches (4) and $\mathrm{cm}(10)$.

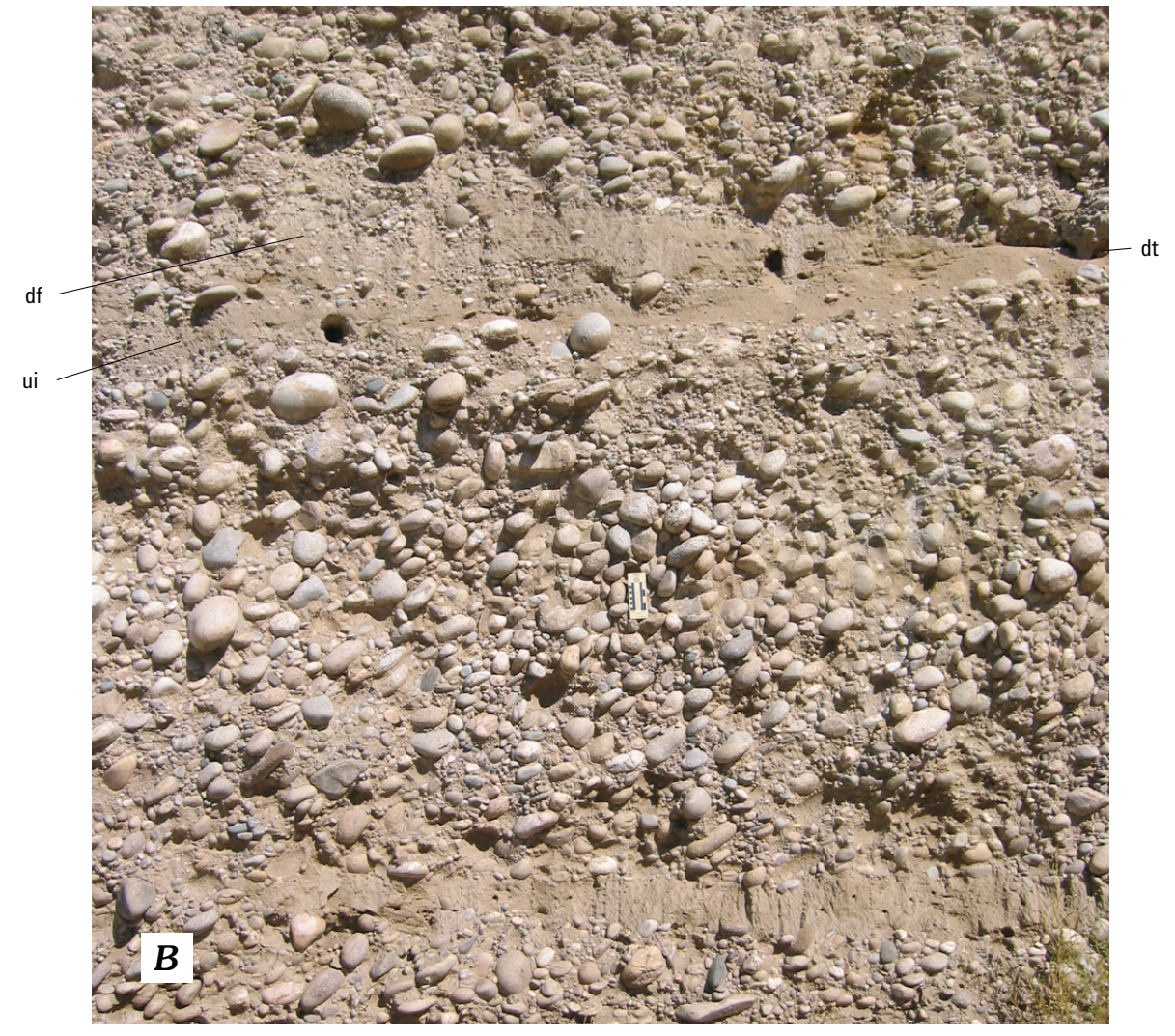


Stratigraphy, Lithology, and Sedimentary Features of Quaternary Alluvial Deposits, S. Platte River and Tributaries, Colo.

Louviers Alluvium on Bear Creek is approximately the same dimension as the one on Clear Creek but takes the form of two large scalloped cuts on the south side of an abandoned gravel pit, with much sloughing of the lower slopes. Exposures are both parallel and transverse to stream flow.

The Bear Creek pit reveals evidence for three gravel units that are continuous across all pit walls. The lower, sloughed part of the section is covered with boulders that are larger than any exposed in pit faces. These boulders are evidently from a coarse basal gravel unit. A middle unit, about $3 \mathrm{~m}$ in thickness, consists of poorly sorted, stratified pebble and cobble gravel with sparse sand lenses. An upper unit, 1-2 m in thickness, consists of boulder gravel; in some places it overlies the middle unit along a sharp contact. Clasts in the upper gravel unit are coated with calcium carbonate. About $0.5 \mathrm{~m}$ of silt overlies the upper gravel unit.

In contrast to Louviers Alluvium of Clear Creek, clasts are larger and more variable in size and sand lenses are smaller in Louviers Alluvium of Bear Creek (fig. 28). Scattered discand blade-shaped clasts of gneiss are in imbricate position, either as single clasts or clusters. Laterally extensive armored surfaces are not evident. Lenses, $0.3-1 \mathrm{~m}$ thick and $1-5 \mathrm{~m}$ in length, of sand and fine gravel in the middle unit and lower part of the upper unit (fig. 28) are probably bar-top or bar-margin features (Ashworth and others, 1992). Some sand lenses have planar foresets that probably formed on slipfaces of small bar-top dunes. Sand accumulations on lee sides of boulders (fig. 28) may also be bar-top features (Reid and others, 1992).

The upper unit contains boulders as much as $0.6 \mathrm{~m}$ in diameter (fig. 28). Even larger boulders of Cretaceous Dakota Sandstone and quartzo-feldspathic gneiss as much as $2 \mathrm{~m}$ in long dimension lie scattered about the quarry floor. These boulders are probably from the lower gravel unit. Sandstone boulders, derived from the Dakota hogback only $1.5 \mathrm{~km}$ away, are angular, but gneiss boulders have broad, rounded surfaces reminiscent of glacial action. Although our convention has been to classify quartzo-feldspathic rocks showing foliation or layering as gneiss, some of the large gneiss boulders found here may have been derived from foliated plutonic rocks described on maps of the Front Range (e.g., Bryant and others, 1981). If the rounded surfaces are glacial, the only possible source would be the small glaciated valleys at the head of Bear Creek, about $40 \mathrm{~km}$ upstream. Whether such long-distance transport is possible might be questioned. Floods having recurrence intervals greater than 500 years, required to transport comparable-size boulders through steep mountain canyons, have been documented for Boulder Creek and the Big Thompson Canyon (Costa, 1983).

The wide range in clast size in Louviers Alluvium of Bear Creek, both within and between gravel layers, indicates

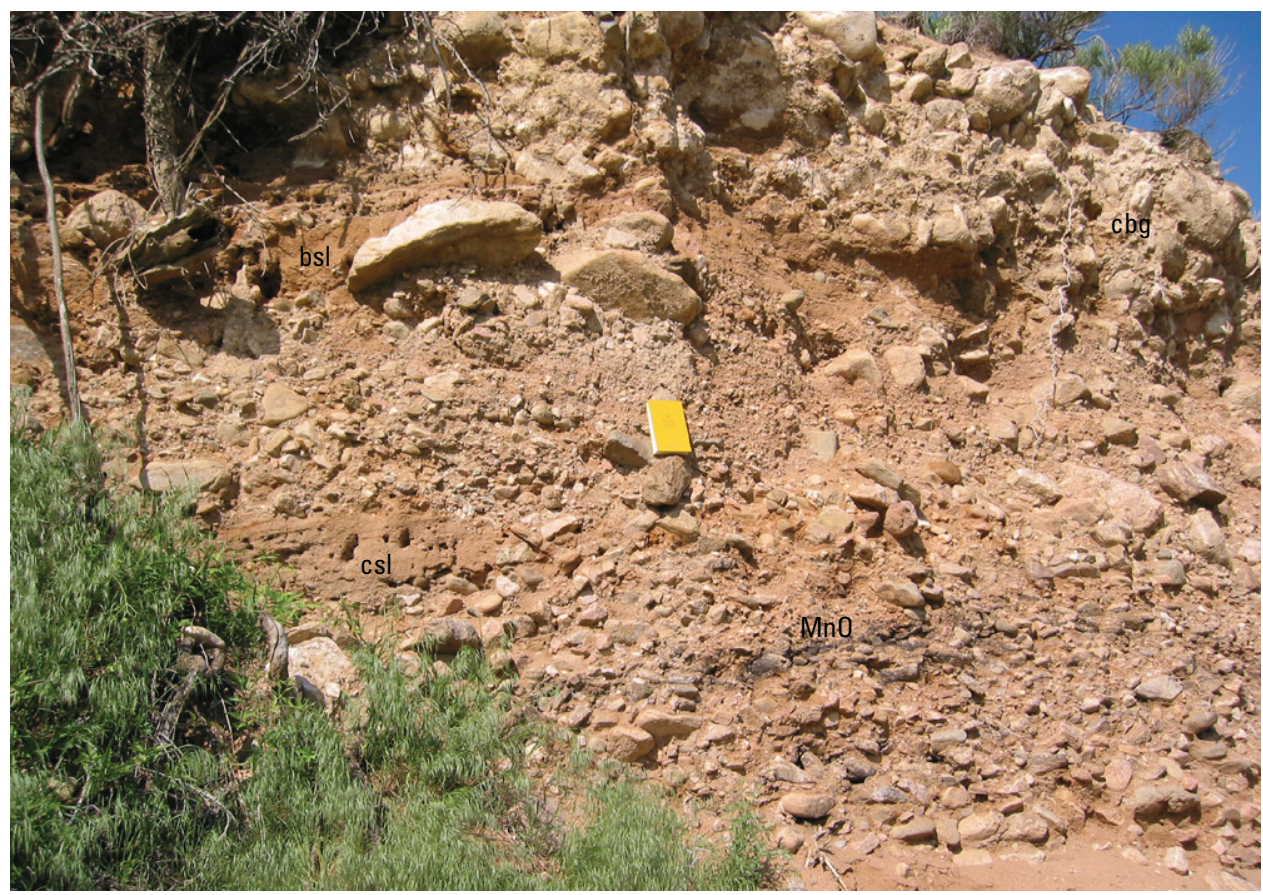

Figure 28. Photograph of flash-flood deposits in Louviers Alluvium at abandoned quarry, south side Bear Creek (field locality 58, fig. 3) east of Morrison. Upper unit of cobble and boulder gravel (cbg), clasts coated with calcium carbonate (Bk soil horizon), about $1 \mathrm{~m}$ in thickness, overlies middle unit of crudely stratified pebble and cobble gravel with brown sand lens (bsl) (upper left of yellow notebook) in downstream shadow of flat boulder; second sand lens (csl), lower left of notebook has foreset laminae (faint) dipping in direction of flow. Flow direction from right to left and toward the viewer. Black stains (below notebook) are manganese oxide ( $\mathrm{MnO})$. Note wide range in clast size, characteristic of flash-flood deposits. Yellow notebook is $15 \mathrm{~cm}$ in length. 
rapid fluctuation in stream power and depth, from flood stage with boulders in transit, to exposure of gravel bars at low water. These conditions are consistent with flash floods. The presence of disparate-sized clasts together in the same layer indicates rapid aggradation; slow accumulation would have allowed time for winnowing of the smallest clasts to locations farther downstream. Locations immediately downstream from bedrock gorges, where stream valleys widen as they exit the mountains, are favorable sites for rapid deposition of large boulders (e.g., Boulder Creek, as discussed by Costa, 1983). At the point where floodwater exited gorges, depth and velocity would diminish rapidly, forcing rapid aggradation and deposition of large boulders.

The vertical succession of large-boulder gravel, pebble and cobble gravel, and boulder gravel could be interpreted as having been deposited by as few as three floods. Differing particle size indicates three different hydraulic competencies, unlike the floods proposed for deposition of Louviers Alluvium of Clear Creek. Only the first flood was powerful enough to cut to bedrock, sweeping away any earlier deposits that might have been present. Each successive flood could not cut through the lower, large-boulder deposit. The flood that deposited the uppermost boulder gravel probably removed the uppermost part of the middle pebble and cobble gravel. Floods are effective agents of channel incision (Maizels, 1987) and may have been responsible for incision in mountain-front reaches of Louviers valleys like that of Bear Creek.

\section{Ralston Creek}

Sedimentary features in thin terrace fill of Verdos Alluvium were examined in pits of the Pioneer Sand and Gravel Co. along Ralston Creek (locality 44, fig. 3). The Ralston Creek pits are about $5 \mathrm{~km}$ from the mountain front, and thus expose gravel deposited approximately the same distance from the mountain front as the pits on Clear and Bear Creeks. Gravel clasts in the Verdos differ from those in the Louviers in composition (abundant schist and amphibolite) and degree of alteration (Verdos Alluvium is highly weathered).

The Verdos Alluvium of Ralston Creek consists mainly of poorly sorted sand-, silt-, and clay-rich gravel deposited in shallow channels. Channel-bottom topography exposed by gravel and clay mining was described under "Stratigraphy." Additionally, the gravel contains crudely defined layers of differing grain size and sorting and rare sand lenses; the layers dip in varying directions at low angles, with the uppermost layers filling broad scours in underlying layers (fig. 29A). Dipping layers appear to be most evident in pit walls oriented transverse to the easterly direction of streamflow. Walls that are oriented east-west, parallel to streamflow, generally show only horizontal layers. The layers are interpreted to represent filling of former shallow channels by accretion. Broad scours in sections transverse to flow represent channel erosion surfaces (fig. 29A). Scour surfaces and inclined, sorted accretionary layers indicate deposition by streamflow, not debris flow.
At some places in the Pioneer pits, the Verdos Alluvium also contains small gravel-filled scours, 1-3 m across and about 1 $m$ deep, formed between times of channel accretion. Possibly similar scours in the top of the Verdos are also described by Van Horn (1976, his fig. 29) at a locality about $2.5 \mathrm{~km}$ west of locality 44 . The occurrence of channels and smaller scours filled with gravel, together with wide range in clast size, suggests highly variable discharge near the mountain front.

Much of the apparent poor sorting and the abundance of matrix in the Verdos Alluvium is the result of soil formation and deep weathering. Machette and others (1976) describe two soil profiles on Verdos Alluvium west of the Pioneer pits. In the pits, reddish-brown, clay-rich B soil horizons with prismatic structure extend as much as $2 \mathrm{~m}$ below the surface (fig. 29B). Below and in the lower part of the B soil horizon, calcium carbonate coats clasts and fills fissures. Many clasts of gneiss, schist, and granitic rock crumble upon touch, even in the lower part of the alluvium. Pedogenic formation of clay and disintegration of clasts probably represents weathering of the relict terrace surface for the entire age of the Verdos Alluvium, estimated to be about $640 \mathrm{ka}$.

\section{Rocky Flats Alluvial Fan}

The Rocky Flats Alluvium was examined at the Bluestone gravel pit (field locality 47, fig. 3), located about $5 \mathrm{~km}$ northwest of the type locality. The Bluestone pit is about 3 $\mathrm{km}$ down slope (east) from the mouth of Coal Creek Canyon. Exposures in the pit were limited to approximately the uppermost $6 \mathrm{~m}$ of alluvium. At the Bluestone pit, Rocky Flats Alluvium consists mostly of coarse, poorly sorted, and weakly stratified gravel (fig. 30A). No differentiation into continuous units of differing composition or grain size could be observed, but weak stratification is defined locally by sparse sand lenses and weakly defined gravel lenses of varying particle size and sorting.

Many small sand and gravel lenses exposed in pit walls measure about 1.5-3 m wide (perpendicular to flow) and $0.3-1 \mathrm{~m}$ in thickness. The largest sand lens, exposed on a pit wall oriented approximately perpendicular to the direction of flow, measured more than $2 \mathrm{~m}$ thick by $15 \mathrm{~m}$ across. Lateral margins of some sand lenses are abrupt and nearly vertical; they were evidently undercut prior to deposition of adjacent gravel. Dimensions of lenses in pit walls oriented parallel to flow are comparable to cross-flow dimensions. Together with bar features described next, the irregular shape of sand lenses probably reflects the bar-and-swale topography commonly observed on alluvial fans (Bull, 1991).

Pit walls oriented parallel to flow direction display clear evidence of structures associated with gravel bars (fig. 30B). Small sand lenses with planar foresets were deposited at the downstream ends of bar tops. Adjoining gravel beds contain isolated imbricate clasts and clusters of imbricated clasts (compare with descriptions by Brayshaw, 1984, and Reid and others, 1992). Imbrication dips west, in the upstream direc- 


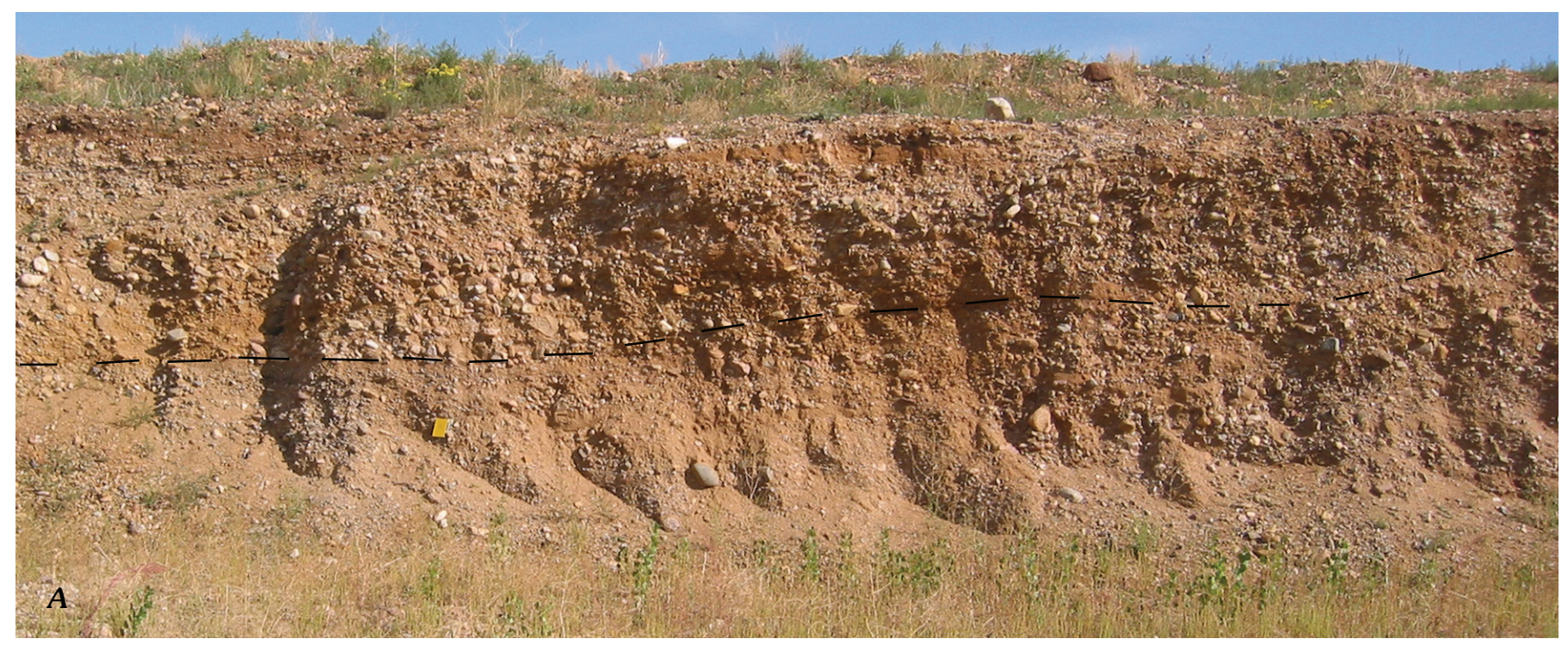

Figure 29. Photographs of Verdos Alluvium, Pioneer gravel pits, north of Ralston Creek (field locality 44, fig. 3). A, Stratification resulting from filling of broad channels (pit wall is about $6 \mathrm{~m}$ high, view is southeast). Layers are concave-up, with those in upper half of pit face dipping to left and truncating those below along channel erosion surface (dashed line). Flow direction was toward the pit wall and about $30^{\circ}-60^{\circ}$ to the left (easterly). $B$, Effects of strong weathering on Verdos Alluvium shown by soil (Btk horizon) with prismatic structure (ps) left of scale and concentrations of calcium carbonate (white patches) coating pebbles and filling fissures. Top of soil has been removed prior to mining. Sand lens in lower left of photo. Scale shows divisions in inches (4) and cm (10).

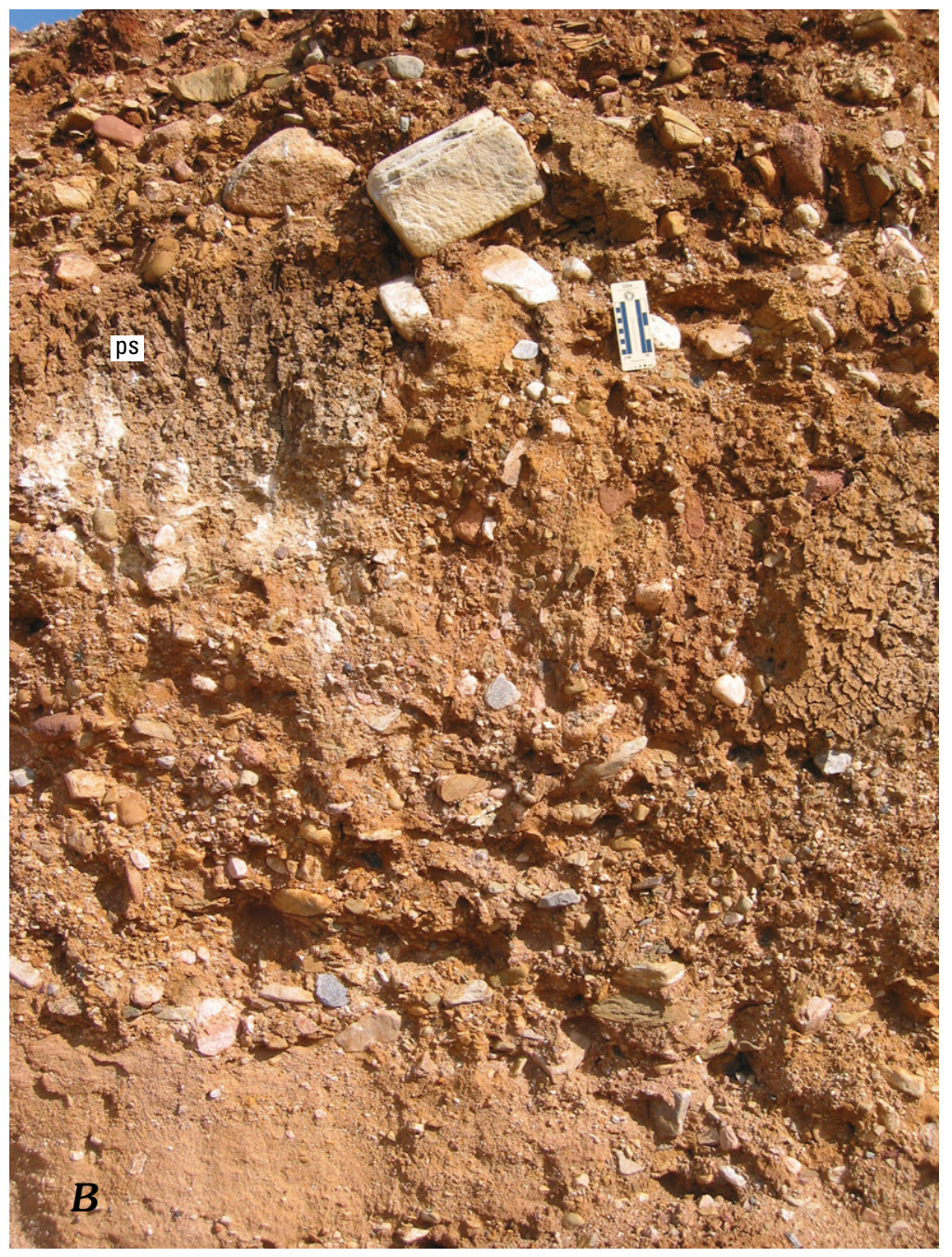



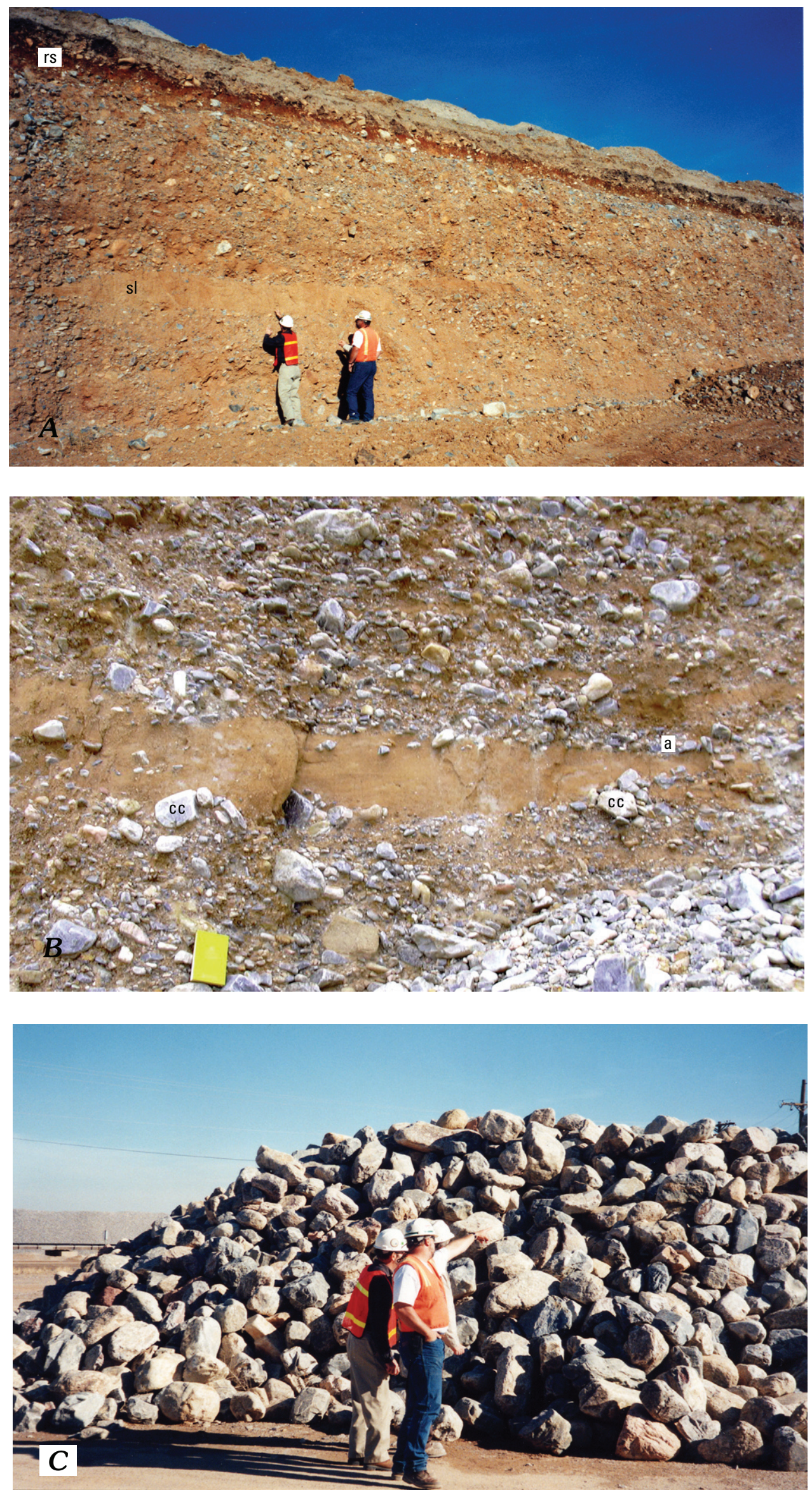

Figure 30. Photographs of Rocky Flats Alluvium at Bluestone pit (field locality 47, fig. 3), Rocky Flats. $A$, Pit wall oriented parallel to flow (left to right), showing deep red soil (rs), poorly stratified gravel with blue-gray quartzite clasts, and man pointing to sand lens (sl); $B$, Detail of pit wall parallel to flow direction (right to left), showing sand lens with planar foresets, clast clusters (cc), weakly developed armor (a) on sand lens, and imbrication; yellow notebook is $15 \mathrm{~cm}$ in long dimension; $C$, Subangular to subrounded quartzite boulders separated from gravel. In $A$ and $B$, note wide range in clast size, typical of flash-flood deposits. 
Stratigraphy, Lithology, and Sedimentary Features of Quaternary Alluvial Deposits, S. Platte River and Tributaries, Colo.

tion. Poorly defined, thin layers of coarse pebbles and cobbles above and below sand lenses are interpreted as weakly developed armor. Imbrication and armor are more weakly developed than in channel and bar deposits of gravel-bed rivers, such as the South Platte, Cache la Poudre, and Clear Creek.

Boulders as large as $0.6 \mathrm{~m}$ in size (fig. 30C) are scattered throughout the exposed interval at the Bluestone pit. Although many clasts in the Rocky Flats gravel are subangular, the presence of rounded corners, even on cobbles and boulders of hard quartzite that have traveled only a few kilometers, is strong evidence of transport and wear in streams. Clasts of softer rocks, such as gneiss, tend to be more rounded than quartzite (Appendix).

The top of the Rocky Flats Alluvium is marked by soils with deep-red B horizons, about $1 \mathrm{~m}$ in thickness (fig. 30A). Machette and others (1976) describe a Rocky Flats soil with strong development of calcium carbonate-cemented zones (K horizons) at the type locality; these were not seen at the Bluestone pit. Like the Verdos Alluvium of Ralston Creek, the interstices of gravel at Rocky Flats contain abundant silt and clay, so much so that the commercial processing of gravel produces very large quantities of silt and clay. Strong alteration of Rocky Flats gravel by soil-forming processes has produced fragile clasts of gneiss that crumble upon touch. It seems likely that much of the silt- and clay-sized matrix is pedogenic.

The structure and texture of Rocky Flats Alluvium is typical of flash-flood deposits in the upstream parts of distributary drainage systems of alluvial fans. Distributary drainage systems (active depositional lobes of Blair and McPherson, 1994a, 1994b) are shallow, often braided, reaches of active deposition, where floodwaters break out of incised channels (e.g., Klawon and Pearthree, 2000). The coarseness and poor sorting of Rocky Flats gravel suggest rapid deposition by streamflood. The high overall proportion of gravel, the presence of scattered boulders, and the absence of thin, laterally extensive sorted beds of pebble gravel typical of sheetflood deposition (Bull, 1972) indicate that deposition was confined to proximal parts of distributary systems. Unconfined sheetfloods are typical of the lower parts of alluvial-fan distributary systems. The presence of thin sand lenses and sorted gravel with locally imbricate clast fabric and clusters, and the lack of matrix-supported gravel, does not favor deposition by debris flows. Taking into account the likelihood that much of the silt and clay now found in the interstices of the Rocky Flats gravel may be pedogenic, there is no reason to cite the abundance of fines as evidence for debris flow.

\section{Alluvium on Drainage Divides}

Outliers of Rocky Flats Alluvium (and, in some places, pre-Rocky Flats and Verdos Alluvium) on drainage divides are remnants of thin $(<3 \mathrm{~m})$ channel fill and lag gravel. Commonly, exposures are too weathered and slumped to permit observation of sedimentary features. At one outlier in Arvada (field locality 57), however, a thin (1-3 m) deposit of interbedded gravel and sand of Rocky Flats Alluvium (Lindvall, 1979b) was exposed by road construction in 2003. Stratigraphic relationships at this locality are probably typical of alluvium on drainage divides. Gravel fills and overtops broad (about $60 \mathrm{~m}$ wide), shallow ( $<2 \mathrm{~m}$ deep) channel scours cut in sandstone and bentonitic mudstone and is overlain locally by thin $(<1.5 \mathrm{~m})$ deposits of loess. Lenses of pebble and cobble gravel rest directly on bedrock (fig. 31A) and interfinger with sand. Despite strongly developed calcareous soil profiles extending into bedrock, primary sedimentary structures are readily visible. Sedimentary structures typical of eroded bars include planar foreset laminae (bar slipfaces, fig. 31A) and imbricate clasts (fig. 31B). Imbrication and foresets at the Arvada locality both indicate east-northeast flow, consistent with tributary streams flowing from the mountains. As noted under "Clast Lithology and Roundness," gravel at this locality contains clasts that were derived from North and South Table Mountain near Golden, indicating transport in a stream that was ancestral to Clear Creek.

\section{Discussion and Conclusions}

\section{Alluvial Stratigraphy}

The alluvial fill of the modern (latest Pleistocene and Holocene) South Platte River valley and its major tributaries contains units that are recognizable and traceable in borehole logs and gravel pits. Although the ages of many units are still poorly understood, the general outlines of the stratigraphy of the modern valley can be discerned (fig. 32). Upstream from Fort Lupton, the modern valley fill of the South Platte River can be divided into a basal gravel unit of probable late Pleistocene age, a middle sandy gravel unit of late Pleistocene(?) and Holocene age, an upper gravel unit of Holocene age, and finegrained overbank deposits (fig. 32A). The coarse basal gravel rests on a valley floor incised into the Broadway terrace and shale of the Denver Formation. Because this gravel contains Pleistocene fossils and is incised into the Broadway terrace, it is regarded as latest Pleistocene. The basal gravel itself is the lag deposit of incision. Incision of possibly comparable age followed deposition of Pinedale-age terraces in the mountain reaches of Boulder Creek (Schildgen and others, 2002). Incision of the South Platte River valley entrained alluvium and increased sediment production, leading to renewed aggradation downstream (complex response), as recorded by the middle sandy unit. In late Holocene time, degradation almost balanced aggradation as the river cut laterally and reworked its alluvial fill.

Our interpretation of the valley fill differs from that of previous workers, who considered the coarse gravel at the bottom of the valley to be laterally continuous with "early Wisconsin" (Hunt, 1954) or Louviers (Scott, 1962) gravel beneath the Broadway terrace (fig. 32B). In their (Hunt, 1954; 

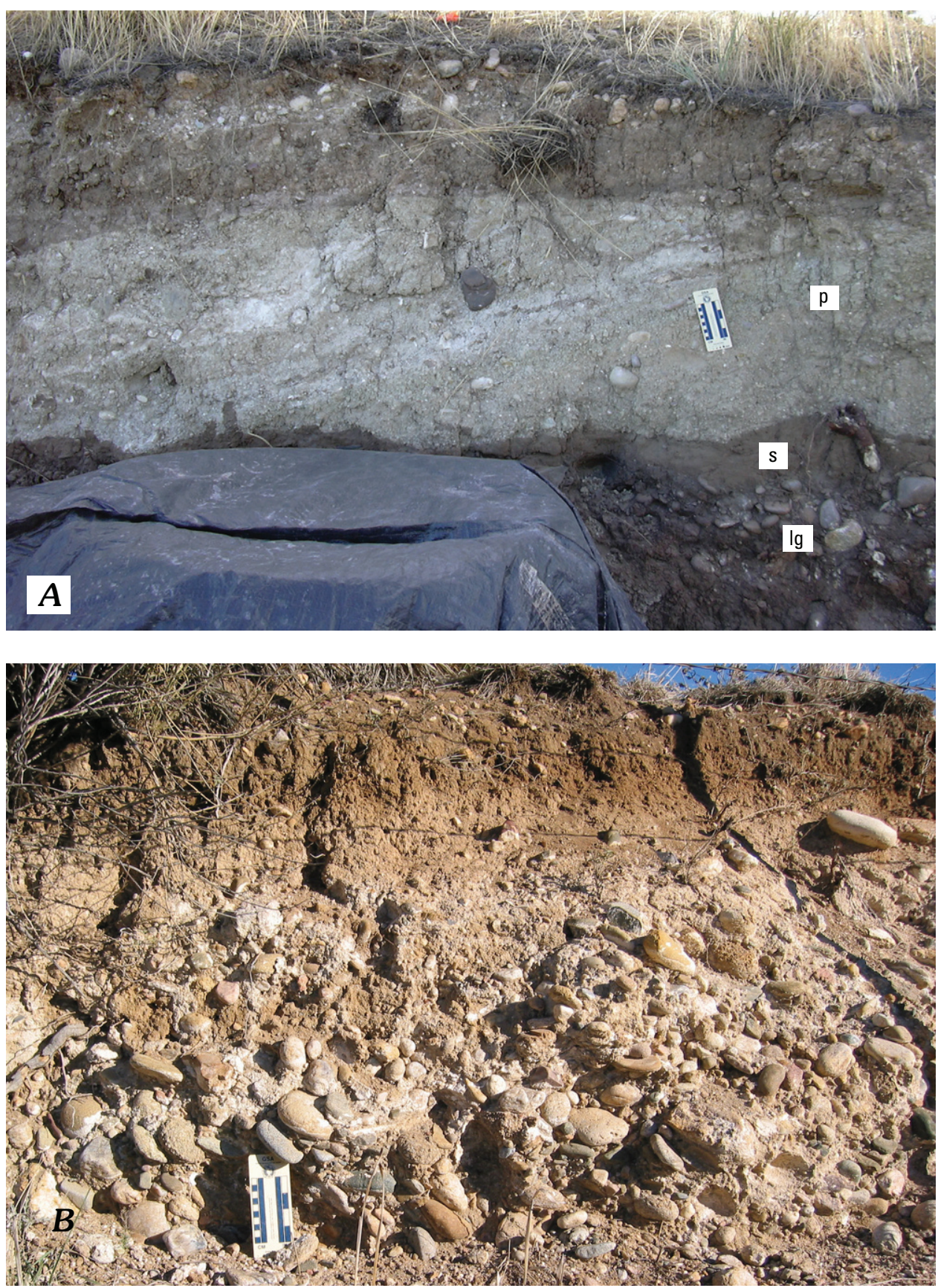

Figure 31. Photographs of sedimentary features of thin gravel of Rocky Flats Alluvium at 72nd Ave and Wadsworth Boulevard, Arvada (field locality 57, fig. 3). A, Planar foresets in gravelly sand (p), silt lens (s), and lag gravel (Ig) at base of alluvium; bedrock of Denver Formation immediately below lag. $B$, Imbricate clasts in lens of gravel. Both photographs: soil profiles are superimposed on alluvium; scale in both photographs shows divisions in inches (4) and cm (10).

Scott, 1962) interpretation, the Broadway terrace fill contained both Louviers and Broadway gravel, and the Louviers gravel was thought to extend beneath Holocene alluvium of the modern valley. No record of latest Pleistocene incision to bedrock was recognized, probably because borehole logs were not yet available to reconstruct the sections of figure 4 . Subsequent mapping (e.g., Lindvall, 1978, 1979a) continued to follow Hunt's (1954) interpretation.

Like the South Platte, the modern valleys of the Cache la Poudre River (Swan, 1975; Langer and Lindsey, 1999) and St. Vrain Creek (Madole, 1976) also contain a lower (late Pleistocene Broadway?) gravel and an upper Holocene 

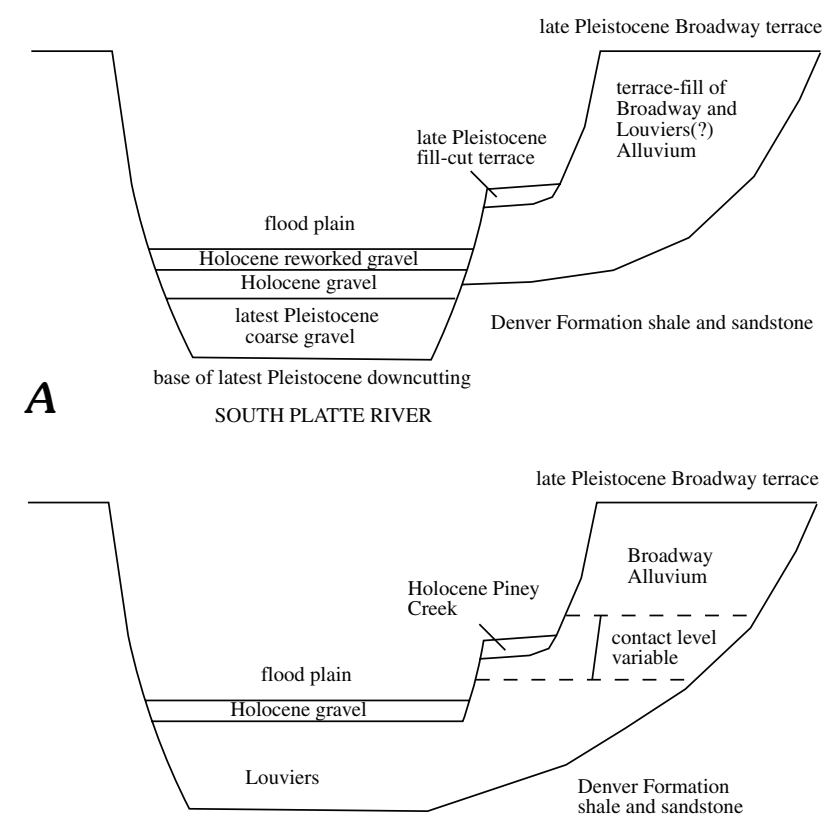

$B$

SOUTH PLATTE RIVER
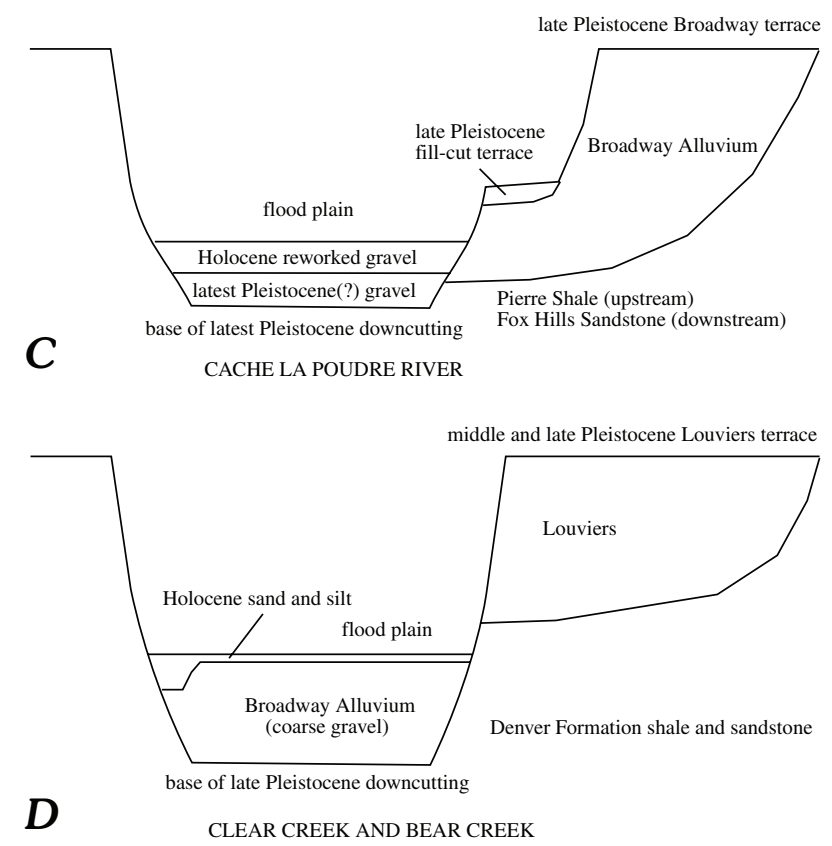

Figure 32. Simplified sections of late Pleistocene and Holocene terraces and fill. $A$ (our interpretation) and $B$ (previous interpretation), South Platte River; $C$, Cache la Poudre River; and $D$, Clear Creek and Bear Creek. Old terrace levels and most overbank deposits not shown. No scale.

gravel unit (fig. 32C). The Cache la Poudre River valley is not deeply incised below the base of adjacent Broadway terrace fill, and thus end-of-Pleistocene downcutting is more difficult to demonstrate than in the South Platte River. The presence of an upper, Holocene gravel unit that is nearly as coarse as the lower fill suggests that the hydraulic competency of the Cache la Poudre to transport coarse gravel was at times nearly the same in Holocene as in late Pleistocene time. The upper gravel unit, and by analogy the lower unit, represents deposition under near-equilibrium conditions where degradation (dominated by lateral cutting) and aggradation were nearly in balance. The late Pleistocene-Holocene histories of St. Vrain Creek, and possibly the Big Thompson River, probably resemble that of the Cache la Poudre River.

In contrast to the larger streams discussed above, Holocene alluvium in the valleys of Clear Creek and Bear Creek appears to be limited to thin deposits of overbank silt and sandy channel gravel (fig. 32D). Coarse gravel underlies Holocene alluvium in these valleys; its age is poorly constrained but its incised position and lesser degree of alteration relative to Louviers Alluvium (Baker, 1973, discusses Clear Creek) suggests that it is Broadway Alluvium. During Holocene time, degradation has been restricted to downcutting in the lower reaches of Clear Creek and Bear Creek. The mostly likely interpretation is that, in response to vastly diminished discharge in Holocene time, these streams have been unable to excavate much of the resistant coarse gravel and, in some reaches of Clear Creek, sandstone of the Denver Formation that form the channel floor.

Broadway and Louviers Alluvium forms extensive fill terraces in the valleys of the South Platte and tributaries that drain from the Front Range. These terraces represent periods of aggradation followed by incision; previously, they have been correlated with climatic cycles (Scott, 1960, 1963). Under the climatic-cycle hypothesis, each alluvial unit is the product of a five-fold sequence of processes: (1) valley cutting (incision), (2) pedimentation (lateral cutting), (3) alluviation (aggradation), (4) wind erosion and deposition, and (5) soil formation (Scott, 1960, 1963). Some or all of these climatic cycles were correlated with the alternation of glacial and interglacial periods. Immediately downstream from glaciated mountain valleys, terrace aggradation and incision may coincide with postglacial sediment production and exhaustion of sediment supply, respectively, as interpreted for Boulder Creek (Schildgen and others, 2002). Increased sediment production is associated with the end of glaciation in upland basins, where large quantities of loose sediment are exposed to erosion and redeposited in larger valleys downstream (Church and Ryder, 1972). Farther downstream on the piedmont, however, the impact of postglacial sediment supply may be weak.

Laterally extensive layers of sand, silt, and clay were deposited on the wide Broadway terrace of the South Platte River Valley. Less extensive layers of sand, silt, and clay were also deposited on Broadway and Louviers terraces of the Cache la Poudre River. Such layers of fine-grained sediment, interbedded with gravel, appear to be confined to terrace fills of Broadway and Louviers Alluvium along major stream valleys. Extensive layers of silt and clay have not been reported in fills of alluvial terraces older than Louviers or in fills of 
narrow, incised tributary valleys such as Bear Creek and Clear Creek. Although a fluvial versus eolian origin cannot be distinguished for these layers, their association with large fill terraces is consistent with deposition at the end of glaciation, when large amounts of fine sediment would have been washed downstream and deposited on flood plains. As suggested by studies of the composition and sources of loess in eastern Colorado, glaciogenic silt from the Front Range was a major source of loess, as was clay-rich shale and volcaniclastic sediment (Aleinikoff and others, 1999; Muhs and others, 1999). Frequent exposure of flood-plain silt to drying and erosion by wind would have produced large quantities of dust, available for deposition in broad valleys of major streams and on adjacent uplands (Hunt, 1954).

The terraces of the South Platte and its tributaries show some indications of nonsynchronous development. Terraces of Slocum, Louviers, and Broadway Alluvium appear to be unpaired in many sections (e.g., as shown in fig. 32), but that appearance is a consequence of subsequent incision along one side of the valley. A few paired terraces are visible on sections (e.g., fig. 12, section $Z-Z^{\prime}$ ), but the treads of some terrace pairs do not lie at the same elevation (e.g., fig. 13, section $C C$ - $C C^{\prime}$ ). Such disconcordant elevations indicate nonsynchronous abandonment of terrace treads; the lower elevation may represent a pause during the incision that followed abandonment. Small unpaired fill-cut terraces (fig. 32) on the riser below the Broadway terrace represent pauses during latest Pleistocene incision.

Old (pre-Rocky Rocky Flats, Rocky Flats, Verdos, and Slocum) alluvium contains a variety of alluvial deposits and geomorphic features. In various places, alluvial fans, stream terraces, and pediments have been identified (Scott, 1963; Madole, 1991). The type Rocky Flats Alluvium was probably deposited as an alluvial fan that covered a hilly, dissected surface (Knepper, 2005). The surface beneath the alluvium on Rocky Flats, long considered a pediment (Scott, 1960), has a strongly dissected appearance, complete with stream valleys, interfluves, and a resistant sandstone hogback of Fox Hills Formation that blocked and diverted drainage. In contrast, pre-Rocky Flats, Rocky Flats, and Verdos Alluvium at other localities are remnants of stream-terrace deposits. Many of these deposits are thin and grade laterally into stream-cut surfaces with little or no gravel cover. Shallow channel fills and gravel lags of Verdos and younger alluvium provide a long record of episodic valley cutting along Ralston and Big Dry Creeks. Remnants of shallow channel fills and gravel lags ranging from pre-Rocky Flats to Verdos Alluvium cap drainage divides between Big Dry Creek, the South Platte River, and Beebe Draw. These deposits consist of deeply weathered gravel that, when well-exposed, exhibits structures typical of channels and bars. They fill and overtop shallow channels cut in bedrock. Although they may be considered as an example of topographic inversion and interpreted as former stream courses (e.g., west of Beebe Draw (Scott, 1982)), their thin nature and incomplete preservation may preclude location of the precise course of ancient streams.

\section{Provenance and Sediment Dispersal}

Lithology and roundness of pebbles can be used to decipher the provenance of alluvial gravel east of the Front Range. Lithology indicates source, but the proportion of rock types is sensitive to weathering and transport. Durable quartzite and vein quartz are resistant to weathering and survive longest in the transport mill; hence, they are useful in reconstructing ancestral drainage systems. In Quaternary alluvium of the South Platte River and its tributaries, quartzite defines a long-lived dispersion path that can be traced back to its source in Precambrian terrane of Coal Creek Canyon. Vein quartz, although widespread in rocks of the Front Range, is most abundant in the conglomerate of the Denver Formation and in amphibolite and schist terrane in the headwaters of Ralston Creek. Rocks of intermediate to low resistance, such as volcanic and mafic metamorphic rocks, also can be traced to their sources, but they may not persist in significant quantities downstream. In the study area, clasts of volcanic rocks were derived from the Denver Formation and Green Mountain Conglomerate, from lava flows near Golden, and from intrusive sills along the mountain front north of Boulder. Clasts of mafic metamorphic rocks define short dispersion paths leading from Precambrian terrane drained by Ralston and Boulder Creeks. Gneiss, granite, and pegmatite, all common and abundant, and soft lithologies such as sandstone, which disappear by abrasion during transport, are least useful as indicators of sediment dispersal.

Clast roundness is an important indicator of provenance in coarse alluvium. Well-rounded pebbles (average roundness $>0.45$ ) characterize Louviers and younger alluvium deposited by major streams whose headwaters originate in glaciated valleys near the crest of the Front Range. Subangular to subround pebbles (average roundness $<0.3$ ) characterize alluvium deposited by short mountain tributaries that arise near the mountain front. Between these extremes, average roundness of pebbles in Slocum and older alluvium ranges from 0.3 to 0.5 , depending on distance from source and recycling. In addition, pebble roundness is strongly controlled by lithology. Soft rocks are rounded easily, hard rocks with difficulty. Pegmatite tends to break along large crystal faces, forming new angular clasts during transport.

The dispersion path of quartzite from Coal Creek Canyon extends east as far the divide between the South Platte River and Beebe Draw, a distance of $60 \mathrm{~km}$. The dispersion path dates from at least early Pleistocene time. The path is evident in terrace remnants of pre-Rocky Flats, Rocky Flats, and Verdos Alluvium on drainage divides on both sides of the South Platte River (figs. 18 and 20). In the same alluvium, a second dispersion path, defined by clasts of vein quartz, volcanic rocks, and mafic metamorphic rocks, intersects the dispersion path of quartzite (figs. 17 and 20). Quartzite in Verdos and older alluvium on both sides of the river has been diluted by large amounts of gneiss, granite, and pegmatite. The terrace remnants reveal the former presence of streams that flowed from the south and followed a course parallel to the pres- 
ent South Platte River. We do not know whether any of these streams was the early Pleistocene South Platte River. Nowhere is the alluvium on the drainage divides known to be as thick as present-day valley fills of the South Platte, but perhaps the main valley fill has been removed by subsequent cutting of the modern South Platte River valley. During middle Pleistocene time, the South Platte River is believed to have flowed through Beebe Draw (Smith and others, 1964). During late Pleistocene time, the South Platte cut its present valley.

Lithology and rounding can be used together to define distinctive clast populations. Angular quartzite clasts at Rocky Flats and angular amphibolite, schist, and gneiss at Ralston Creek are near-source populations. Ancestral tributaries, such as Ralston Creek and Clear Creek, can be identified from distinctive clast populations in remnants of terrace gravel. Mixed populations indicate joining of tributaries to form major streams. The mixed clast population formed by the intersection of quartzite and other dispersion paths is one example. Well-rounded populations of gneiss, granite, pegmatite and other clasts distinguish Louviers and younger alluvium deposited by major streams that head in glaciated valleys. Not all clast populations of Louviers and younger alluvium are well rounded; angular populations are seen in flash-flood deposits in the valley of Bear Creek.

\section{Depositional Processes}

Sedimentary features can be used to divide the Quaternary alluvium of streams arising in the mountains into two broad categories: (1) gravel deposits formed by intermittent deposition and scouring, and (2) deposits formed rapidly by flash floods. The first category embraces a range of deposits formed under conditions that range from aggradational to degradational. They include (a) stacked and amalgamated bar deposits that result from lateral and vertical accretion in channels (aggradation dominant), (b) amalgamated bar deposits that result from lateral accretion (lateral cutting and redeposition at near-grade conditions), and (c) shallow channel fills and lag deposits left on channel floors and straths (degradation dominant). Annual meltwater floods (e.g., Baker, 1974; Hein and Walker, 1977) were probably responsible for deposition of most category-1 deposits. Summer cloudbursts (e.g., Costa, 1983; Shroba, Schmidt, Crosby, and Hansen, 1979) were probably responsible for most category-2 deposits.

The Louviers Alluvium of Clear Creek and the late Pleistocene(?) and Holocene middle sandy gravel unit of the South Platte River are interpreted to have formed by lateral and vertical accretion of bars (aggradation dominant, category 1a). These two deposits differ in grain size (coarse gravel versus sandy pebble gravel) and structures, but both consist of stacked and amalgamated forms left by channel and bar migration. Beds of imbricate pebbles and cobbles separated by thin sand lenses characterize coarse deposits formed under aggrading conditions. Planar and trough crossbedding char- acterizes sandy gravel deposits. Erosional scours formed by migrating channels and bars indicate that aggradation was episodic, with much winnowing and downstream flushing of fine particles. Coarse gravel-bar deposits of the Cache la Poudre River upstream from Fort Collins may also have formed under moderately aggrading conditions.

Deposits formed by scouring and redeposition of gravel bars at near-grade conditions (category 1b) dominate the Holocene upper gravel units of large gravel-bed streams, including the South Platte and Cache la Poudre Rivers. These deposits formed by lateral cutting and back-filling as channels migrated across the valley floor. Channel erosion surfaces, some merging with more extensive erosional disconformities, and slabs and intraclasts of silty sediment caved from banks are the principal indications of lateral cutting and accretion. Not all of these features are present together in a single outcrop or pit face, but they can be identified by study of long cuts. Other features seen in deposits of near-grade gravel bed streams, such as accretionary laminae separated by reactivation surfaces, complete bar sequences (of apron, foreset, and topset laminae of Crowley, 1983), and armor layers of imbricate clasts formed on channel bottoms and bar tops, are not diagnostic of lateral cutting; they may also form in aggradation-dominant streams.

We do not think that the assemblage of sedimentary features identified in late Pleistocene and Holocene fill of the South Platte and Cache la Poudre Rivers is diagnostic of braided versus meandering channel pattern. Unfortunately, internal stratification of bars is not diagnostic of bar type or channel pattern (Crowley, 1983). This lack of distinction is not surprising inasmuch as channel processes among rivers having meandering and braided patterns are similar (Bristow, 1996). In addition, the channel pattern of these streams may have varied in the past, so that present channel patterns and bedforms are not an indication of those that prevailed during the past. For example, Eschner and others (1983) documented drastic reductions in channel width and changes in discharge in the Platte River system since the onset of canal and dam construction for irrigation in 1860. Such changes were undoubtedly accompanied by changes in channel pattern and bedforms. Today, meandering gravel-bed channels with bank-attached bars at meander bends predominate in the upper South Platte and Cache la Poudre Rivers; braided channels and in-channel bars predominate downstream in the Platte River (Crowley, 1983). However, the gravel to sand, silt, and clay vertical sequence described from point bars in some meandering gravel-bed rivers (e.g., Campbell and Hendry, 1987) is not apparent in the Holocene upper gravel unit of either stream. Instead, gravel is complexly interleaved with sand (South Platte River) or occurs largely without sand (Cache la Poudre River) and is overlain directly by overbank sediment.

Presence or absence of overbank deposits does not imply a particular channel pattern. The upper, Holocene gravel unit of both the South Platte and Cache la Poudre Rivers is overlain by fine-grained overbank sediment, but underlying gravel units are not. However, in the South Platte north of Denver, large 
stratified slabs and intraclasts of fine-grained sediment lie on the scoured base of the upper unit. These slabs are interpreted as remnants of caved banks, and they indicate that, in the past, overbank sediment was present but was removed when the river cut laterally across its valley. Likewise, overbank sediment of present-day streams is swept downstream during floods, while gravel is left behind in channels and bars. In this manner, gravel-bed streams form a complex sequence of channel and bar deposits that, except for the current flood plain, is mostly lacking in fine-grained sediment. There is no need to appeal to a braided-stream model where overbank deposits are absent (e.g., Miall, 1978). The lack of overbank sediment can be explained entirely by lack of preservation (Jackson, 1978; Bristow, 1996).

Shallow channel fills and gravel lags (category 1c) consist of variably sorted and rounded pebble and cobble gravel deposited by streams on surfaces cut into soft bedrock. Gravel ranges from poorly sorted and rounded gravel near sources to moderately well sorted and rounded downstream. Structures include imbricate clasts and foreset laminae. Shallow channel fills pass laterally into lags of pebbles and cobbles on nearly level bedrock surfaces interpreted as straths.

Louviers Alluvium on Bear Creek typifies gravel interpreted as flash-flood deposits (category 2). These are not deposits of sediment gravity flows; they contain some of the same channel and bar structures found in category 1 deposits. However, the Louviers gravel of Bear Creek is coarser and varies more in clast size and sorting than gravel deposits formed by intermittent scour and deposition, such as the Louviers Alluvium of Clear Creek. Large rounded boulders occur at distinct horizons, including the base of the deposit. Overall rounding of pebble-size clasts is much less than that of other large streams. Small crossbedded sand lenses located downstream from boulders and clast clusters are interpreted as features that formed as floodwater subsided. The preservation of a very large range of clast sizes in poorly sorted gravel indicates rapid aggradation. Such coarse, rapidly deposited fluvial deposits are found at the mouths of steep mountain canyons, where floodwaters spread laterally and lose their competence to transport coarse detritus. Examples of flash-flood deposits deposited by streams at the mouths of steep canyons have been documented along the margin of the Front Range (Costa, 1983).

The alluvial fan at Rocky Flats was also deposited by flash floods where they exited the steep mountain canyon of Coal Creek. Rocky Flats Alluvium at Rocky Flats contains sedimentary features and textures similar to the Louviers Alluvium of Bear Creek. Small sand lenses, gravel-bar features, and large range in clast size including abundant scattered cobbles and boulders are consistent with deposition during rapidly fluctuating discharge. Initially the Rocky Flats floods flowed through valleys much like those that confined the Louviers floods at Bear Creek, but after the valleys were filled, distributary streams built a fan of coarse alluvium. The dominance of fluvial flash-flood deposits and the absence of sediment gravity flow deposits in the Rocky Flats fan prob- ably stems from a particular combination of catchment area characteristics and climate. Although low catchment slopes and large catchment basins favor fluvial over sediment gravity flow deposition (Harvey, 1992), neither condition was present at Rocky Flats. Perhaps climate or lithology of the catchment were determining factors.

\section{References Cited}

Aleinikoff, J.N., Muhs, D.R., Saur, R.R., and Fanning, C.M., 1999, Late Quaternary loess in northeastern Colorado: Part $\mathrm{II}-\mathrm{Pb}$ isotopic evidence for the variability of loess sources: Geological Society of America Bulletin, v. 111, no. 12, p. 1876-1883.

Ashworth, P.J., Ferguson, R.I., and Powell, M.D., 1992, Bedload transport and sorting in braided channels, with Discussions by P. Ergenzinger and T. Hoey, and Reply by P.J. Ashworth, R.I. Ferguson, and M.D. Powell, in Billi, P., Hey, R.D., Thorne, C.R., and Tacconi, P., eds., Dynamics of gravel-bed rivers: Chichester, U.K., Wiley, p. 497-515.

Ashley, G.M., Symposium Chairman, 1990, Classification of large-scale subaqueous bedforms: A new look at an old problem: Journal of Sedimentary Petrology, v. 60, no. 1, p. 160-172.

Baker, V.R., 1973, Paleosol development in Quaternary alluvium near Golden, Colorado: Mountain Geologist, v. 10, no. 4, p. 127-133.

Baker, V.R., 1974, Paleohydraulic interpretation of Quaternary alluvium near Golden, Colorado: Quaternary Research, v. 4, no. 1, p. $94-112$.

Barnett, A., and Ellefsen, K.J., 2000, Assessment of the alluvial sediments in the Big Thompson River Valley, Colorado: U.S. Geological Survey Digital Data Series DDS-66, 11 p., 2 pls.

Birkeland, P.W., Miller, D.C., Patterson, P.E., Price, A.B., and Shroba, R.R., 1996, Soil-geomorphic relationships near Rocky Flats, Boulder and Golden, Colorado, area, with a stop at the pre-Fountain Formation paleosol of Wahlstrom (1948): Colorado Geological Survey Open-File Report 96-4, Field Trip No. 27, 13 p.

Blair, T.C., and McPherson, J.G., 1994a, Alluvial fans and their natural distinction from rivers based on morphology, hydraulic processes, sedimentary processes, and facies assemblages: Journal of Sedimentary Research, v. A64, no. 3, p. 450-489.

Blair, T.C., and McPherson, J.G., 1994b, Alluvial fan processes and forms, in Abrahams, A.D., and Parsons, A.J., eds., Geomorphology of desert environments: London, Chapman \& Hall, p. 354-402. 
Bluck, B.J., 1982, Texture of gravel bars in braided streams, with Discussion by R.D. Hey, and Reply by B.J. Bluck, in Hey, R.D., Bathurst, J.C., and Thorne, C.R., eds., Gravelbed rivers: Chichester, U.K., Wiley, p. 339-355.

Bluck, B.J., 1987, Bed forms and clast size changes in gravelbed rivers, in Richards, K.S., ed., River channels: environment and process: Oxford, U.K., Blackwell, The Institute of British Geographers Special Publications Series 17, p. 159-178.

Braddock, W.A., and Cole, J.C., 1978, Preliminary geologic map of the Greeley $1^{\circ} \times 2^{\circ}$ quadrangle, Colorado and Wyoming: U.S. Geological Survey Open-File Report 78-532, scale $1: 250,000$.

Braddock, W.A., Houston, R.G., Colton, R.B., and Cole, J.C., 1988, Geologic map of the Lyons quadrangle, Boulder County, Colorado: U.S. Geological Survey Geologic Quadrangle Map GQ-1629, scale 1:24,000.

Brayshaw, A.C., 1984, Characteristics and origin of cluster bedforms in coarse-grained alluvial channels, in Koster, E.H., and Steel, R.J., eds., Sedimentology of gravels and conglomerates: Calgary, Canadian Society of Petroleum Geologists Memoir 10, p. 77-85.

Bristow, C., 1996, Reconstructing fluvial channel morphology from sedimentary sequences, in Carling, P.A., and Dawson, M.R., eds., Advances in fluvial dynamics and stratigraphy: Chichester, U.K., Wiley, p. 351-371.

Bryan, K. and Ray, L. L., 1940, Geologic antiquity of the Lindenmeier site in Colorado: Smithsonian Miscellaneous Collections, v. 90 , no. 2, 76 p.

Bryant, B., McGrew, L.W., and Wobus, R.A., 1981, Geologic map of the Denver $1^{\circ} \times 2^{\circ}$ quadrangle, north-central Colorado: U.S. Geological Survey Miscellaneous Investigations Series Map I-1163, scale 1:250,000.

Bucher, W.H., 1932, "Strath" as a geomorphic term: Science, v. 275 , no. 1935 , p. 130-131.

Bull, W.B., 1972, Recognition of alluvial-fan deposits in the stratigraphic record, in Rigby, J.K., Hamblin, W.K., eds., Recognition of ancient sedimentary environments: Society of Economic Paleontologists and Mineralogists Special Publication 16, p. 63-83.

Bull, W.B., 1991, Geomorphic responses to climatic change: New York, Oxford University Press, 326 p.

Campbell, J.E., and Hendry, H.E., 1987, Anatomy of a gravelly meander lobe in the Saskatchewan River, near Nipawin, Canada, in Ethridge, F.G., Flores, R.M., and Harvey, M.D., eds., Recent developments in fluvial sedimentology: Society of Economic Paleontologists and Mineralogists Special Publication No. 39, p. 179-196.
Church, M.A., and Ryder, J.M., 1972, Paraglacial sedimentation: A consideration of fluvial processes conditioned by glaciation: Geological Society of America Bulletin, v. 83, no. 10 , p. 3059-3072.

Church, M.A., McLean, D.G., and Wolcott, J.F., 1987, River bed gravels: sampling and analysis, with Discussions by R. Fehr and M.N.R. Jaeggi, G. Parker, A.M. Harvey, P.C. Klingeman, G. Petts, D.I. Bray, and R. Kellerhals, and Reply by M. Church, D.G. McLean, and J.F. Wolcott, in Thorne, C.R., Bathurst, J.C., and Hey, R.D., eds., Sediment transport in gravel-bed rivers: Chichester, U.K., Wiley, p. 43-88.

Collinson, J.D., 1970, Bedforms of the Tana River, Norway: Geografiska Annaler, v. 52, series A, Physical Geography, p. 31-56.

Colton, R.B., 1978, Geologic map of the Boulder-Fort Collins-Greeley area, Front Range Urban Corridor, Colorado: U.S. Geological Survey Miscellaneous Investigations Map I-855-G, scale 1:100,000.

Colton, R.B., and Fitch, H.R., 1974, Map showing potential sources of gravel and crushed-rock aggregate, in the Boulder-Fort Collins-Greeley area, Front Range Urban Corridor, Colorado: U.S. Geological Survey Miscellaneous Investigations Map I-855-D, scale 1:100,000.

Costa, J.E., 1983, Paleohydraulic reconstruction of flash-flood peaks from boulder deposits in the Colorado Front Range: Geological Society of America Bulletin, v. 94, no. 8, p. 986-1004.

Crosby, E.J., 1978, Landforms in the Boulder-Fort CollinsGreeley area, Front Range Urban Corridor, Colorado: U.S. Geological Survey Miscellaneous Investigations Series Map I-855-H, scale 1:100,000.

Crowley, K.D., 1983, Large-scale bed configurations (macroforms), Platte River basin, Colorado and Nebraska: Primary structures and formative processes: Geological Society of America Bulletin, v. 94, no. 1, p. 117-133.

Dames \& Moore, 1981, Final report-Geologic and seismologic investigations of Rocky Flats Plant for U.S. Department of Energy: Denver, Colo., v. 3 (29 plates).

Dethier, D.P., Benedict, J.B., Birkeland, P.W., Caine, N., Davis, P.T., Madole, R.F., Patterson, P.E., Price, A.B., Schildgen, T.F., and Shroba, R.R., 2003, Quaternary stratigraphy, geomorphology, soils, and alpine archaeology in an alpineto-plains transect, Colorado Front Range, in Easterbrook, D.J., ed., Quaternary geology of the United States: Reno, Nevada, INQUA 203 Field Guide Volume, Desert Research Institute, p. 81-104.

Dethier, D.P., Schildgen, T., Bierman, P., and Caffee, M., 2001, Cosmogenic analysis of the Rocky Flats Alluvium 
near Boulder, Colorado [abs.]: Geological Society of America Annual Meeting, Nov. 1-10, 2001, Boston, Mass., Abstracts with Programs, v. 33, no. 6, p. A-312.

EG\&G Rocky Flats, Inc., 1991, Geologic characterizationPrepared for the U.S. Department of Energy, Rocky Flats area office: Golden, Colo., EG\&G Rocky Flats, Inc., 54 p.

Eschner, T.R., Hadley, R.F., and Crowley, K.D., 1983, Hydrologic and morphologic changes in channels of the Platte River basin in Colorado, Wyoming, and Nebraska: A historical perspective, in Hydrologic and geomorphic studies of the Platte River basin: U.S. Geological Survey Professional Paper 1277-A, 39 p.

Gable, D.J., compiler, 2000, Geologic map of the Proterozoic rocks of the central Front Range, Colorado: U.S. Geological Survey Geologic Investigations Series I-2605, scale 1: 100,000 .

Harvey, A.M., 1992, Controls on sedimentary style on alluvial fans, in Billi, P., Hey, R.D., Thorne, C.R., and Tacconi, P., eds., Dynamics of gravel-bed rivers: Chichester, U.K., Wiley, p. 519-535.

Hein, F.J., and Walker, R.G., 1977, Bar evolution and development of stratification in the gravelly, braided Kicking Horse River: Canadian Journal of Earth Science, v. 14, no. 4, pt. 1, p. $562-570$.

Hunt, C.B., 1954, Pleistocene and recent deposits in the Denver area, Colorado: U.S. Geological Survey Bulletin 996-C, p. 91-140.

Izett, G.A., and Wilcox, R.E., 1982, Map showing localities and inferred distribution of the Huckleberry Ridge, Mesa Falls, and Lava Creek ash beds in the Western United States: U.S. Geological Survey Miscellaneous Investigations Map I-1325, scale 1:4,000,000.

Jackson, R.G., II, 1978, Preliminary evaluation of lithofacies models for meandering alluvial streams, in Miall, A.D., ed., Fluvial sedimentology: Calgary, Canadian Society of Petroleum Geologists Memoir 5, p. 543-576.

Jenkins, E.D., 1961, Records and logs of selected wells and test holes, and chemical and radiometric analyses of ground water in the Boulder area: Colorado Water Conservation Board Basic Data Report No. 5, 26 p.

Klawon, J.E., and Pearthree, P.A., 2000, Field guide to a dynamic distributary drainage system: Tiger Wash, western Arizona: Arizona Geological Survey Open-File Report 0001, $34 \mathrm{p}$.

Knepper, D.H., Jr., ed., 2002, Planning for the conservation and development of infrastructure resources in urban areas-Colorado Front Range Urban Corridor: Things planners, decision-makers, and the public should know: U.S. Geological Survey Circular 1219, 27 p.
Knepper, D.H., Jr., 2005, Bedrock erosion surface beneath the Rocky Flats alluvial fan, Jefferson and Boulder Counties, Colorado: Mountain Geologist, v. 42, no. 1, p. 1-8.

Langer, W.H., and Lindsey, D.A., 1999, Preliminary deposit models for sand and gravel in the Cache la Poudre River valley: U.S. Geological Survey Open-File Report 99-587, $27 \mathrm{p}$.

Lanphere, M.A., Champion, D.E., Christiansen, R.L., Izett, G.A., and Obradovich, J.D., 2002, Revised ages for tuffs of the Yellowstone Plateau volcanic field: Assignment of the Huckleberry Ridge Tuff to a new geomagnetic polarity event: Geological Society of America Bulletin, v. 114, no. 5, p. 559-568.

Laughon, R.B., 1963, A study of weathering of terrace gravels along South Boulder Creek, Colorado: Boulder, Colo., University of Colorado, unpub. M.S. thesis, $43 \mathrm{p}$.

Lindsey, D.A., 2001, Lithology of gravel deposits of the Front Range Urban Corridor, Colorado: Data and multivariate statistical analysis: U.S. Geological Survey Open-File Report 01-299, 9 p.

Lindsey, D.A., 2003, Lithologic controls on aggregate quality in a mountain-front alluvial system-An example from the Colorado Front Range: Society for Mining, Metallurgy, and Exploration Transactions, v. 314, p. 19-30.

Lindsey, D.A., and Langer, W.H., 1998, Defining models and measuring aggregate quality for gravel deposits of the Front Range Urban Corridor, Colorado, in Johnson, K.S., ed., Proceedings, 34th Forum on the Geology of Industrial Minerals, 2-6 May 1998, Norman, Oklahoma: Oklahoma Geological Survey Circular 102, p. 125-137.

Lindsey, D.A., Langer, W.H., Cummings, L.S., and Shary, J.F., 1998, Gravel deposits of the South Platte River valley north of Denver, Colorado, Part A-Stratigraphy and sedimentary structures: U.S. Geological Survey Open-File Report 98148-A, $18 \mathrm{p}$.

Lindsey, D.A., Langer, W.H., and Shary, J.F., 1998, Gravel deposits of the South Platte River valley north of Denver, Colorado, Part B-Quality of gravel deposits for aggregate: U.S. Geological Survey Open-File Report 98-148-B, 24 p.

Lindsey, D.A., and Shary, J.F., 1997, Field measures of gravel in the South Platte River north of Denver, Colorado-A pilot study: U.S. Geological Survey Open-File Report 97451, $19 \mathrm{p}$.

Lindsey, D.A., Taggart, J.E., and Meeker, G.P., 1998, Gravel deposits of the South Platte River valley north of Denver, Colorado, Part C-Description, composition, and origin of clay lenses in gravel: U.S. Geological Survey Open-File Report 98-148-C, 7 p. 
Lindvall, R.M., 1978, Geologic map of the Fort Logan quadrangle, Jefferson, Denver, and Arapahoe Counties, Colorado: U.S. Geological Survey Geologic Quadrangle Map GQ-1427, scale 1:24,000.

Lindvall, R.M., 1979a, Preliminary geologic map of the Commerce City quadrangle, Adams and Denver Counties, Colorado: U.S. Geological Survey Miscellaneous Field Studies Map MF-1067, scale 1:24,000.

Lindvall, R.M., 1979b, Geologic map of the Arvada quadrangle, Adams, Denver, and Jefferson Counties, Colorado: U.S. Geological Survey Geologic Quadrangle Map 1453, scale 1:24,000.

Machette, M.N., 1977, Geologic map of the Lafayette quadrangle, Adams, Boulder, and Jefferson Counties, Colorado: U.S. Geological Survey Map GQ-1392, scale 1:24,000.

Machette, M.N., Birkeland, P.W., Markos, G., and Guccione, M.J., 1976, Soil development in Quaternary deposits in the Golden-Boulder portion of the Colorado piedmont, in Epis, R.C., and Weimer, R.J., eds., Studies in Colorado field geology: Colorado School of Mines Professional Contributions No. 8, p. 339-357.

Mackin, J.H., 1970, Origin of pediments in the Western United States, in Pésci, M., ed., Problems of relief planation: Budapest, Akadémiai Kiadó, p. 85-105.

Madole, R.F., 1976, Differentiation of upper Pleistocene and Holocene gravels along St. Vrain Creek, eastern Boulder County, Colorado [abs.]: American Quaternary Association, Abstracts of the Fourth Biennial Meeting, October 9 and 10, 1976, Arizona State University, Tempe, Arizona, p.146.

Madole, R.F., 1991, "Colorado piedmont section,” in Wayne, W. J., and others, Quaternary geology of the northern Great Plains, in Morrison, R.B., ed., Quaternary nonglacial geology; conterminous U.S.: Boulder, Colo., Geological Society of America, v. K-2, p. 456-462.

Madole, R.F., 1995, Origin of Pleistocene eolian sand sheets on the west-central Great Plains, Colorado [abs.]: Geological Society of America Abstracts with Programs, NorthCentral Section, p. 70.

Madole, R.F., Braddock, W.A., and Colton, R.B., 1998, Geologic map of the Hygiene quadrangle, Boulder County, Colorado: U.S Geological Survey Geologic Quadrangle Map GQ-1772, scale 1:24,000.

Madole, R.F., Van Sistine, D.P., Michael, J.A., 1998, Pleistocene glaciation in the upper Platte River drainage basin, Colorado: U.S. Geological Survey Geologic Investigations Series Map I-2644.

Maizels, J.K., 1987, Large-scale flood deposits associated with formation of coarse-grained braided terrace sequences, in Ethridge, F.G., Flores, R.M., and Harvey, M.D., eds., Recent developments in fluvial sedimentology: Society of Economic Paleontologists and Mineralogists Special Publication No. 39, p. 135-148.

Malde, H.E., 1955, Surficial geology of the Louisville quadrangle, Colorado: U.S. Geological Survey Bulletin 996-E, p. 217-259.

McConaghy, J.A., Chase, G.H., Boettcher, A.J., and Major, T.J., 1964, Hydrologic data of the Denver Basin, Colorado: Colorado Water Conservation Board Basic Data Report No. 15,224 p.

McKee, E.D., Crosby, E.J., and Berryhill, H.L., Jr., 1967, Flood deposits, Bijou Creek, Colorado, June, 1965: Journal of Sedimentary Petrology, v. 37, no. 3, p. 829-851.

Miall, A.D., 1978, Lithofacies types and vertical profile models in braided river deposits, in Miall, A.D., ed., Fluvial sedimentology: Calgary, Canadian Society of Petroleum Geologists Memoir 5, p. 597-604.

Miall, A.D., 1996, The geology of fluvial deposits: Berlin, Springer, $582 \mathrm{p}$.

Mills, H.H., 1979, Downstream rounding of pebbles-A quantitative review: Journal of Sedimentary Petrology, v. 49, no. 1, p. 295-302.

Mosley, M.P., and Schumm, S.A., 2001, Gravel bed riversThe view from the hills, with Discussions by R.G. Millar and S. Rice, and Reply by M.P. Mosley and S.A. Schumm, in Mosley, M.P., ed., Gravel-bed rivers V: Wellington, New Zealand Hydrological Society, p. 479-505.

Muhs, D.R., Aleinikoff, J.N., Stafford, T.W., Jr., Kilh, R., Been, J., Mahan, S.A., and Cowherd, S., 1999, Late Quaternary loess in northeastern Colorado: Part I-Age and paleoclimatic significance: Geological Society of America Bulletin, v. 111, no. 12, p. 1861-1875.

Pettijohn, F.J., 1975, Sedimentary rocks (3rd ed.): New York, Harper and Row, 628 p.

Potter, P.E., and Pettijohn, F.J., 1963, Paleocurrents and basin analysis: New York, Academic Press, 296 p.

Pye, K., 1987, Aeolian dust and dust deposits: London, Academic Press, 334 p.

Reid, I., Frostick, L.E., and Brayshaw, A.C., 1992, Microform roughness elements and the selective entrainment and entrapment of particles in gravel-bed rivers, with Discussions by P.A. Carling, P. Billi, C. de Jong, L.B. Leopold, P.C. Klingeman, and J.B. Laronne, and Reply by I. Reid, L.E. Frostick, and A. Brayshaw, in Billi, P., Hey, R.D., Thorne, C.R., and Tacconi, P., eds., Dynamics of gravel-bed rivers: Chichester, U.K., Wiley, p. 253-275. 
Ritter, D.F., 1986, Process geomorphology (2nd ed.): Dubuque, Iowa, W.C. Brown Publishers, 579 p.

Ritter, D.F., 1987, Fluvial processes in the mountains and intermontane basins, in Madole, R.F., Bradley, W.C., Loewenherz, D.S., Ritter, D.F., Rutter, N.W., and Thorn, C.E., Rocky Mountains, chap. 7 of Graf, W.L., ed., Geomorphic systems of North America: Boulder, Colo., Geological Society of America, Centennial Special Volume 2, p. 220-228

Robson, S.G., 1996, Geohydrology of the shallow aquifers in the Denver metropolitan area, Colorado: U.S. Geological Survey Hydrologic Investigations Atlas HA-736, scale 1: 50,000 .

Schildgen, T., Dethier, D.P., Bierman, P., and Caffee, M., 2002, ${ }^{26} \mathrm{Al}$ and ${ }^{10} \mathrm{Be}$ dating of late Pleistocene and Holocene fill terraces: A record of fluvial deposition and incision, Colorado Front Range: Earth Surface Process and Landforms, v. 27, no. 7, p. 773-787.

Schneider, P.A., Jr., 1962, Records and logs of selected wells and test holes, and chemical analyses of ground water in the South Platte River basin in western Adams and southwestern Weld Counties, Colorado: Colorado Water Conservation Board, Basic Data Report No. 9, 84 p.

Schneider, P.A., Jr., and Hershey, L.A., 1961, Records and logs of selected wells and test holes, and chemical analyses of ground water in the lower Cache la Poudre River basin, Colorado: Colorado Water Conservation Board Basic Data Report No. 8, 63 p.

Schumm, S.A., 1977, The fluvial system: New York, Wiley, $338 \mathrm{p}$.

Schwochow, S.D., 1972, Surficial geology of the Eastlake quadrangle, Adams County, Colorado: Golden, Colo., Colorado School of Mines, unpub. M.S. thesis, $152 \mathrm{p}$.

Schwochow, S.D., Shroba, R.R., and Wicklein, P.C., 2000, Atlas of sand, gravel, and quarry aggregate resources, Colorado Front Range counties: Colorado Geological Survey Open-File report 00-9 (CD-ROM).

Scott, G.R., 1960, Subdivision of the Quaternary alluvium east of the Front Range near Denver, Colorado: Geological Society of America Bulletin, v. 71, no. 10, p. 1541-1544.

Scott, G.R., 1962, Geology of the Littleton quadrangle, Jefferson, Douglas, and Arapahoe Counties, Colorado: U.S. Geological Survey Bulletin 1121-L, 53 p.

Scott, G.R., 1963, Quaternary geology and geomorphic history of the Kassler quadrangle, Colorado: U.S. Geological Survey Professional Paper 421-A, 70 p.

Scott, G.R., 1965, Nonglacial Quaternary geology of the southern and middle Rocky Mountains, in Wright, H.E., Jr., and Frey, D.G., eds., The Quaternary of the United States: Princeton, N.J., Princeton University Press, p. 243-254.

Scott, G.R., 1972, Geologic map of the Morrison quadrangle, Jefferson County, Colorado: U.S. Geological Survey Folio for the Morrison quadrangle, Map I-790-A, scale 1:24,000.

Scott, G.R., 1982, Paleovalley and geologic map of northeastern Colorado: U.S. Geological Survey Miscellaneous Investigations Map I-1378, scale 1:250,000.

Shroba, R.R., 1980, Geologic map and physical properties of the surficial and bedrock units of the Englewood quadrangle, Denver, Arapahoe, and Adams Counties, Colorado: U.S. Geological Survey Geologic Quadrangle Map GQ1524 , scale 1:24,000.

Shroba, R.R., and Carrara, P.E., 1996, Surficial geologic map of the Rocky Flats Environmental Technology Site and vicinity, Jefferson and Boulder Counties, Colorado: U.S. Geological Survey Miscellaneous Investigations Series Map I-2526, scale 1:12,000.

Shroba, R.R., Schmidt, P.W., Crosby, E.J., and Hansen, W.R., 1979, Geologic and geomorphic effects in the Big Thompson Canyon area, Larimer County, with a section on Damage caused by geological processes during flood producing storms, by J.M. Soule, in Storm and flood of July 31-August 1, 1976, in the Big Thompson River and Cache la Poudre River basins, Larimer and Weld Counties, Colorado: U.S. Geological Survey Professional Paper 1115, Part B, p. 87-152.

Siegel, S., 1956, Nonparametric statistics for the behavioral sciences: New York, McGraw-Hill, 312 p.

Simons, D.B., and Li, R.-M., 1982, Bank erosion on regulated rivers, with Discussions by N.G. Bhowmik, C.R. Thorne and W.C. Little, and C.R. Thorne, and Reply by D.B. Simons and R.-M. Li, in Hey, R.D., Bathurst, J.C., and Thorne, C.R., eds., Gravel-bed rivers: Chichester, U.K., Wiley, p. 717-754.

Smith, N.D., 1978, Some comments on terminology for bars in shallow rivers, in Miall, A.D., ed., Fluvial sedimentology: Calgary, Canadian Society of Petroleum Geologists Memoir 5 , p. $85-88$.

Smith, N.D., 1985, Proglacial fluvial environment, in Ashley, G.M., Shaw, J., and Smith, N.D., eds., Glacial sedimentary environments: SEPM Short Course No. 16, p. 85-134.

Smith, R.O., Schneider, P.A., Jr., and Petri, L.R., 1964, Ground-water resources of the South Platte River basin in western Adams and southwestern Weld Counties, Colorado: U.S. Geological Survey Water-Supply Paper 1658, 132 p.

Snedecor, G.W., and Cochran, W.G., 1967, Statistical methods (6th ed.): Ames, Iowa, Iowa State University Press, 593 p. 
Soister, P.E., 1965a, Geologic map of the Fort Lupton quadrangle, Weld and Adams Counties, Colorado: U.S. Geological Survey Geologic Quadrangle Map GQ-397, scale 1: 24,000 .

Soister, P.E., 1965b, Geologic map of the Hudson quadrangle, Weld and Adams Counties, Colorado: U.S. Geological Survey Geologic Quadrangle Map GQ-398, scale 1:24,000.

Soister, P.E., 1965c, Geologic map of the Platteville quadrangle, Weld County, Colorado: U.S. Geological Survey Geologic Quadrangle Map GQ-399, scale 1:24,000.

Sutherland, A.J., 1987, Static armour layers by selective erosion, with Discussions by M.N.R. Jaeggi, I. Reid, and L.E. Frostick, L.E. Frostick and I. Reid, C.R. Thorne, D.S. Biedenharn, and K.J. Bruxvoort, and Reply by A.J. Sutherland, in Thorne, C.R., Bathurst, J.C., and Hey, R.D., eds., Sediment transport in gravel-bed rivers: Chichester, U.K., Wiley, p. 243-267.

Swan, F.H., III, 1975, Pleistocene and Holocene deposits of the lower Cache la Poudre River basin, Colorado: Baltimore, Md., The Johns Hopkins University, unpub. Ph.D. dissertation, $172 \mathrm{p}$.

Trimble, D.E., 1975, Geologic map of the Niwot quadrangle, Boulder County, Colorado: U.S. Geological Survey Geologic Quadrangle Map GQ-1229, scale 1:24,000.

Trimble, D.E., and Machette, M.N., 1979, Geological map of the greater Denver area, Front Range Urban Corridor, Colorado: U.S. Geological Survey Miscellaneous Investigations Map I-856-H, scale 1:100,000.
Tweto, O., 1987, Rock units of the Precambrian basement in Colorado: U.S. Geological Survey Professional Paper 1321A, $54 \mathrm{p}$.

Van Horn, R., 1972, Surficial and bedrock geologic map of the Golden quadrangle, Jefferson County, Colorado: U.S. Geological Survey Atlas of the Golden quadrangle, Map I-761-A, scale 1:24,000.

Van Horn, R., 1976, Geology of the Golden quadrangle, Colorado: U.S. Geological Survey Professional Paper 872, $116 \mathrm{p}$.

Varnes, D.J., and Scott, G.R., 1967, General and engineering geology of the United States Air Force Academy site, Colorado, with a section on ground water by W.D.E. Cardwell and E.D. Jenkins: U.S. Geological Survey Professional Paper 551, 93 p.

Wells, J.D., 1967, Geology of the Eldorado Springs quadrangle, Boulder and Jefferson Counties, Colorado: U.S. Geological Survey Bulletin 1221-D, 85 p.

Wells, J.D., Sheridan, D.M., Albee, A.L., 1964, Relationship of Precambrian quartzite-schist sequence along Coal Creek to Idaho Springs Formation, Front Range, Colorado: U.S. Geological Survey Professional Paper 454-O, 25 p.

Willis, B.J., 1993, Interpretation of bedding geometry within ancient point-bar deposits, in Marzo, M., and Puigdefabregas, C., eds., Alluvial sedimentation: Oxford, Blackwell Scientific Publications, International Association of Sedimentologists Special Publication No. 17, p. 101-114.
Published in the Central Region, Denver, Colorado

Manuscript approved for publication December 28, 2004

Editing, page layout, photocomposition-Richard W. Scott, Jr. Cover design-Amber Hess

Graphics prepared by the authors 


\section{Appendix: Lithologic Control of Rounding in Different Clast Populations}

\section{Method}

The ease with which clasts are rounded varies with hardness and, to some extent, grain size and structure. Among the lithologies studied here, clasts of soft rocks, such as sandstone and mafic rocks (amphibolite, schist, and diabase), round easily over short distances of alluvial transport. Clasts of harder rocks, such as gneiss, granite (including compositional variants such as quartz monzonite and granodiorite), and volcanic rocks, round during prolonged transport. The hardest rocks, vein quartz and quartzite, resist rounding during transport, but they too, with prolonged transport, eventually become rounded. Pegmatite is a special case: it fractures along the boundaries between large mineral grains during weathering and transport and tends to form smaller, angular clasts downstream. The role of streamflow characteristics in rounding is unknown. Characteristics such as channel roughness, bedload particle size, discharge, turbulence, and extreme events may affect the rapidity with which certain lithologies round.

The degree to which lithology and roundness are correlated in individual clast populations can be tested with contingency tables, where the two attributes are used simultaneously to classify individual clasts. In addition, contingency tables of lithology and roundness can be used to characterize and compare clast populations. Such combinations of characteristics may have genetic significance. If a number of clast populations share a common pattern, they may also share a common provenance.

A contingency table shows the relationship of two characteristics, such as lithology and roundness, in the form of a data matrix. For an hypothetical example, granite and pegmatite clasts may be classified as angular or rounded, and the results cast in the $2 \times 2$ matrix of observed frequencies shown below; larger tables can accommodate more categories. In the example, the results of each row and column are totaled and shown in one additional row and column, respectively.

\begin{tabular}{lccc}
\hline \multicolumn{1}{c}{ Lithology } & Angular & Rounded & Totals \\
\hline Granite & 5 & 15 & 20 \\
Pegmatite & 25 & 5 & 30 \\
Totals & 30 & 20 & 50 \\
\hline
\end{tabular}

A second table of frequencies can be calculated to represent the expected values for the hypothesis that there is no correlation between lithology and roundness. Expected values are calculated by multiplying the row and column totals for each cell and dividing the product by the total number of cases. Thus, the expected frequency for the first cell in the first row (angular granite) would be $20 \times 30 / 50=12$, and the table of expected frequencies would be as follows:

\begin{tabular}{lccc}
\hline \multicolumn{1}{c}{ Lithology } & Angular & Rounded & Totals \\
\hline Granite & 12 & 8 & 20 \\
Pegmatite & 18 & 12 & 30 \\
Totals & 30 & 20 & 50 \\
\hline
\end{tabular}

Finally, a table of chi-square values can be calculated; chi-square for each cell is the square of the difference between observed and expected frequencies divided by the expected frequency. Thus, chi-square for the first cell (angular granite) would be $(5-12)^{2} / 12=4.083$. The total of all cell chi-square values for the contingency table is 17.01 . The cell chi-square table is as follows:

\begin{tabular}{lll}
\hline \multicolumn{1}{c}{ Lithology } & Angular & Rounded \\
\hline Granite & 4.083 & 6.125 \\
Pegmatite & 2.722 & 4.083 \\
\hline
\end{tabular}

One can now ask whether there is a significant correlation between lithology and roundness. By consulting a chi-square table in a statistics text such as Siegel (1956), for one degree of freedom, a chi-square value of 17.01 is significant at 0.001 level. Stating the null hypothesis, there is less than one chance in 1,000 that lithology and roundness are uncorrelated. Degrees of freedom are calculated as the product of the number of rows minus one and the number of columns minus one. Finally, an examination of the individual cell chi-square values reveals that the difference between observed and expected frequencies of rounded granite is contributing most to the total chi-square value; rounded granite is much more abundant than would be expected if lithology and rounding were uncorrelated. Note that the relative contributions to chi-square are not intuitive from the table of observed frequencies. In calculating chi square, care must be taken not to permit inclusion of small expected frequencies; the guideline used here is to accept no expected frequencies below one and not permit more than 20 percent of all expected frequencies to be less than five (Siegel, 1956). If small expected frequencies are encountered, the initial contingency table should be modified by combining or deleting categories. Other details and limitations of contingency tables are discussed in statistics texts (Siegel, 1956; Snedecor and Cochran, 1967).

\section{Application of Method}

Seven data sets, each thought to represent distinct clast populations, were examined for relationships between roundness and lithology. These data sets represent differences in source rock including contributions of recycled clasts, distance 
from source, stream size, and whether headwater valleys were glaciated or unglaciated. For the data sets tested, the latter two characteristics cannot be separated with certainty. Two data sets represent near-source gravel of short mountain streams with no evidence of glaciation in headwater valleys. Of these, one data set is dominated by hard quartzite (Rocky Flats and upper Big Dry Creek), and one by soft amphibolite and schist (Ralston Creek). Two data sets represent Slocum and older alluvium with large contributions of recycled clasts. Of these, one set contains abundant near-source recycled clasts from the Denver Formation and Green Mountain Conglomerate. The other set represents gravel recycled from multiple sources on the divide between Big Dry Creek and the South Platte River; it represents more distant transport than the first three data sets; stream size is unknown. Finally, three data sets (Clear Creek, South Platte River north of Denver, and Cache la Poudre River) represent far-traveled gravel deposited by large streams with glaciated headwater valleys.

The poorly rounded quartzite-rich gravel at Rocky Flats and upper Big Dry Creek is of Rocky Flats and Verdos Alluvium (table A1, fig. A1). The type Rocky Flats Alluvium is probably an alluvial-fan deposit, whereas the Verdos Alluvium immediately downstream is composed of terrace gravel that has been recycled from Rocky Flats Alluvium. Samples of the two units were combined because both are near $(<15 \mathrm{~km})$ their ultimate source in gneiss and metaquartzite terrane in the headwaters of Coal Creek. In this quartzite-rich gravel, gneiss shows a much greater tendency to round than vein quartz and quartzite (table A1). For gneiss, the observed frequency of angular and subangular clasts (roundness classes $\mathrm{A}+\mathrm{B}$ ) is less than the expected frequency, and the observed frequency of rounded clasts (class D) is greater than expected. To a lesser extent, the opposite is true of vein quartz and quartzite: the observed frequency of rounded clasts (class D) is less than expected. Thus, rounding of gneiss is already well underway only a few kilometers from the source, but hard, angular quartz and quartzite resist rounding. Verdos Alluvium on upper Big Dry Creek has been recycled once, during Verdos time. Nevertheless, total transport distances were short and angular corners and edges inherited from jointing and layering in quartzite remained well preserved.

Another example of near-source, poorly rounded gravel is terrace fill of Verdos and Piney Creek Alluvium along Ralston Creek (table A2, fig. A2). Although of much different ages, these two alluvial terrace fills coincide with the present position of Ralston Creek and were derived from the same terrane, so samples were combined in order to increase the power of the chi-square test. Angular to subround clasts (classes A, B, and C) predominate, in keeping with short transport distance, $15-20 \mathrm{~km}$. For pegmatite, the observed frequency of angular to subangular clasts (classes $\mathrm{A}+\mathrm{B}$ ) is greater than the expected frequency, whereas the observed frequency of rounded and well-rounded clasts (classes D+E) is less than expected. For mafic rocks and sandstone, the observed frequency is greater than expected for rounded clasts (classes D+E), indicating that rounding is already underway for these soft lithologies, with the caveat that only small numbers of clasts were observed.

Moderately rounded gravel in small terraces that extend off Green Mountain is derived largely from the Denver Formation and the Green Mountain Conglomerate and to a lesser extent from Cretaceous sandstone beneath the Denver Formation (table A3, fig. A3). Samples from Rocky Flats, Verdos, and Slocum Alluvium were combined because all contain a large component of recycled clasts from conglomerate and have been transported only a short distance $(3-5 \mathrm{~km})$ from their source at Green Mountain. Samples of Slocum and Verdos, collected from the south side of Green Mountain, contain noticeable amounts of sandstone; a sample of Rocky Flats Alluvium from the north side does not. Except for pegmatite and volcanic rocks, the terrace gravel of Green Mountain shows no strong relationship between lithology and roundness. For pegmatite, the observed frequency of rounded and well-rounded clasts is less than expected. Volcanic rocks show a less-than-expected frequency for subround (class C) clasts and greater-than-expected frequency for rounded plus wellrounded (classes D+E) clasts of volcanic rocks. Rounding of volcanic clasts may be inherited from the Denver Formation and Green Mountain Conglomerate, where they have already undergone considerable rounding.

Moderately rounded gravel of Rocky Flats and Verdos Alluvium covers terrace remnants on the divide between Big Dry Creek and the South Platte River (table A4, fig. A4). These remnant gravels represent somewhat greater transport distances $(15-40 \mathrm{~km})$ than the first three examples. They are located on the dispersion paths of metaquartzite from Coal Creek Canyon and of volcanic rock and vein quartz from the Green Mountain and Table Mountain areas near Golden. Subround and rounded clasts (classes C and D) predominate, as is typical of moderately transported gravel of Slocum and older alluvium in the study area. For granite, the observed frequency of angular plus subangular (classes $\mathrm{A}+\mathrm{B}$ ) and subround (class $\mathrm{C}$ ) clasts is much less than expected, whereas the observed frequency of rounded (class D) and well-rounded (class E) clasts is much greater than expected. For vein quartz + quartzite, two resistant lithologies, the opposite is true; the observed frequency of angular plus subangular (classes $\mathrm{A}+\mathrm{B}$ ) clasts is greater than expected and the observed frequency of well-rounded (class E) clasts is less than expected. Thus, in the gravel remnants between Big Dry Creek and the South Platte River, granite clasts tend to high degrees of roundness whereas vein quartz + quartzite tend to remain angular. Roundness of gneiss, pegmatite, and mafic rocks is not correlated with lithology; all show few deviations from expected frequencies.

Well-rounded gravel of Louviers and Broadway Alluvium in terrace fill of Clear Creek shows the results of long distance transport (as much as $50 \mathrm{~km}$ ) in a stream where flood discharge was probably enhanced by glacial meltwater (table A5, fig. A5). Rounded and well-rounded clasts predominate. Lithology and rounding of Louviers and Broadway resemble one another and justify combining the two. The 
Table A1. Lithology versus roundness of pebbles in Rocky Flats and Verdos Alluvium, Rocky Flats and upper Big Dry Creek.

[Pebble size: 1-3 in (2.5-7.6 cm). Based on three samples of approximately 100 pebbles each from three localities, one in Rocky Flats Alluvium and two in Verdos Alluvium. Roundness classes: A, angular; B, subangular; C, subrounded; D, rounded (Pettijohn, 1975, fig. 3-24). OBS, observed frequency; EXP, expected frequency. $\mathrm{CHI}^{2}$, cell chi-square value. Totals, observed and expected frequencies for roundness (columns) and lithologies (rows). For the contingency table, chi square $=20.8$; significance $=<0.001$. Lithologies having zero frequency for some roundness classes (granite, mafic rocks, and sandstone) omitted from table]

\begin{tabular}{l|rrr|rrr|rrr|r}
\hline \multicolumn{1}{c}{ Lithology } & \multicolumn{3}{c|}{ Roundness A+B } & \multicolumn{3}{c|}{ Roundness C } & \multicolumn{3}{c|}{ Roundness D } & \multirow{2}{*}{ Totals } \\
& OBS & EXP & CHI & OBS & EXP & CHI $^{2}$ & OBS & EXP & CHI $^{\mathbf{2}}$ & \\
\hline Gneiss & 16 & 25.9 & 3.78 & 18 & 19.1 & 0.06 & 22 & 11.0 & 10.90 & 56 \\
Pegmatite & 11 & 10.6 & 0.01 & 9 & 7.8 & 0.19 & 3 & 4.5 & 0.53 & 23 \\
Vein quartz & 7 & 6.0 & 0.17 & 6 & 4.4 & 0.58 & 0 & 2.6 & 2.60 & 13 \\
Quartzite & 102 & 93.5 & 0.77 & 67 & 68.7 & 0.04 & 33 & 39.9 & 1.19 & 202 \\
Totals & 136 & 136.0 & & 100 & 100.0 & & 58 & 58.0 & & 294 \\
\hline
\end{tabular}

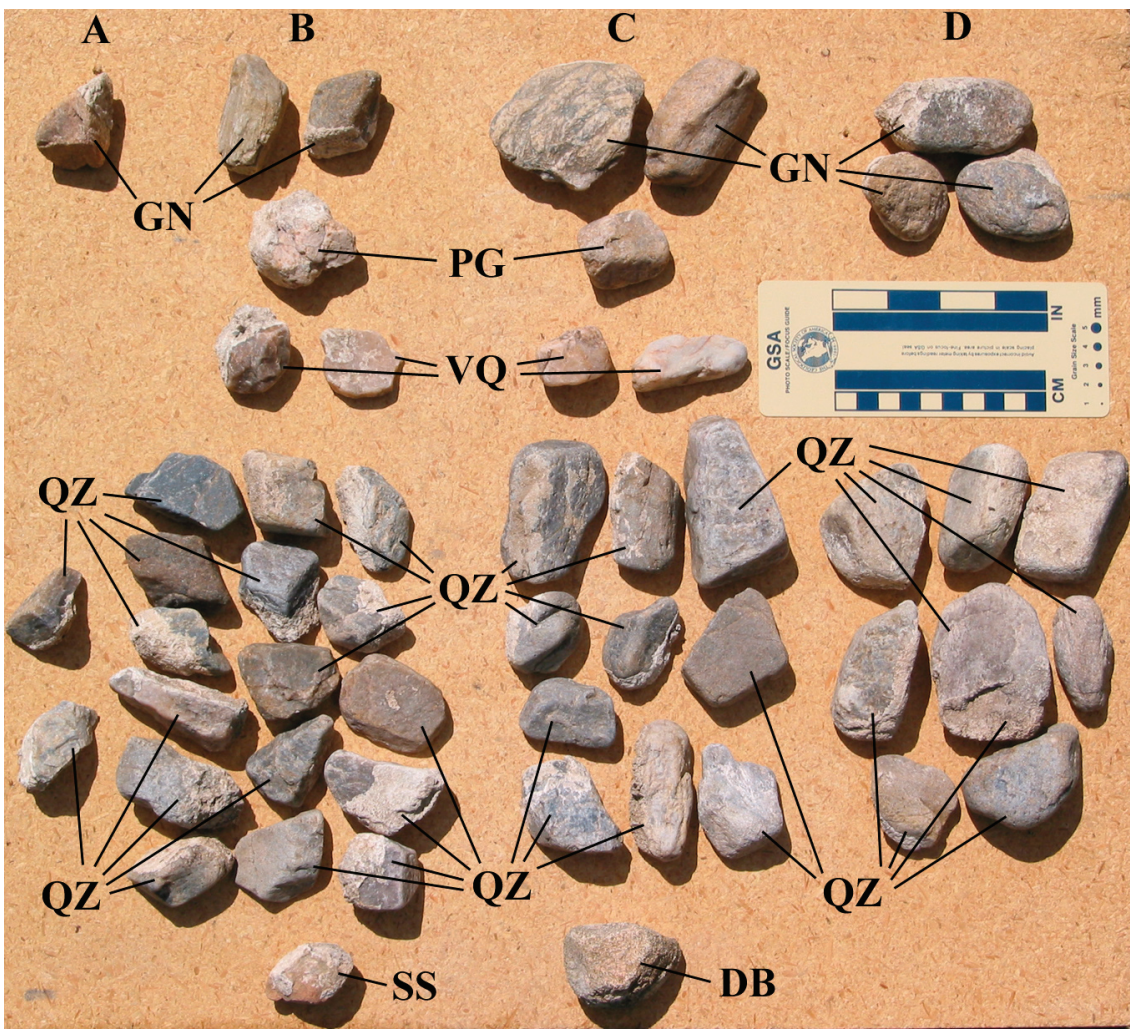

Figure A1. Poorly rounded quartzite gravel, Verdos Alluvium, field locality 50, Rocky Flats. A second-cycle gravel, derived from Rocky Flats Alluvium. Collection composed of about 50 pebbles drawn from a larger sample; roundness and lithologies are close to proportions counted in the whole sample. Pebbles arranged in columns of equal roundness ( $A$, angular; $B$, subangular; $C$, subround; $D$, rounded) and rows of like lithology (GN, quartzo-feldspathic gneiss (includes foliated granite); PG, pegmatite; V0, vein quartz; $0 Z$, quartzite; DB, diabase; SS, sandstone). Scale shows centimeters (bottom) and inches (top). 
Table A2. Lithology versus roundness of pebbles in Verdos and Piney Creek Alluvium, Ralston Creek.

[Pebble size: 1-3 in (2.5-7.6 cm). Based on samples of approximately equal size from two localities, one in Verdos Alluvium and one in Piney Creek Alluvium. Roundness classes: A, angular; B, subangular; C, subrounded; D, rounded; E, well rounded (Pettijohn, 1975, fig. 3-24). OBS, observed frequency; EXP, expected frequency. $\mathrm{CHI}^{2}$, cell chi-square value. Totals, observed and expected frequencies for roundness (columns) and lithologies (rows). For the contingency table, chi square $=16.7$; significance $=0.034$. Lithologies having zero frequency for some roundness classes (granite) omitted from table]

\begin{tabular}{|c|c|c|c|c|c|c|c|c|c|c|}
\hline \multirow[t]{2}{*}{ Lithology } & \multicolumn{3}{|c|}{ Roundness $A+B$} & \multicolumn{3}{|c|}{ Roundness C } & \multicolumn{3}{|c|}{ Roundness D+E } & \multirow[t]{2}{*}{ Totals } \\
\hline & OBS & EXP & $\mathrm{CHI}^{2}$ & OBS & EXP & $\mathrm{CHI}^{2}$ & OBS & EXP & $\mathrm{CHI}^{2}$ & \\
\hline Gneiss & 16 & 16.6 & 0.02 & 24 & 25.7 & 0.12 & 12 & 9.6 & 0.57 & 52 \\
\hline Pegmatite & 21 & 14.1 & 3.42 & 21 & 21.8 & 0.03 & 2 & 8.2 & 4.66 & 44 \\
\hline Vein quartz + quartzite & 6 & 6.4 & 0.02 & 13 & 9.9 & 0.98 & 1 & 3.7 & 1.98 & 20 \\
\hline Mafic rocks ${ }^{1}$ & 16 & 20.1 & 0.85 & 31 & 31.2 & 0.00 & 16 & 11.7 & 1.59 & 63 \\
\hline Sandstone & 3 & 4.8 & 0.67 & 7 & 7.4 & 0.02 & 5 & 2.8 & 1.77 & 15 \\
\hline Totals & 62 & 62.0 & & 96 & 96.0 & & 36 & 36.0 & & 194 \\
\hline
\end{tabular}

${ }^{1}$ Amphibolite, biotite schist, and diabase.

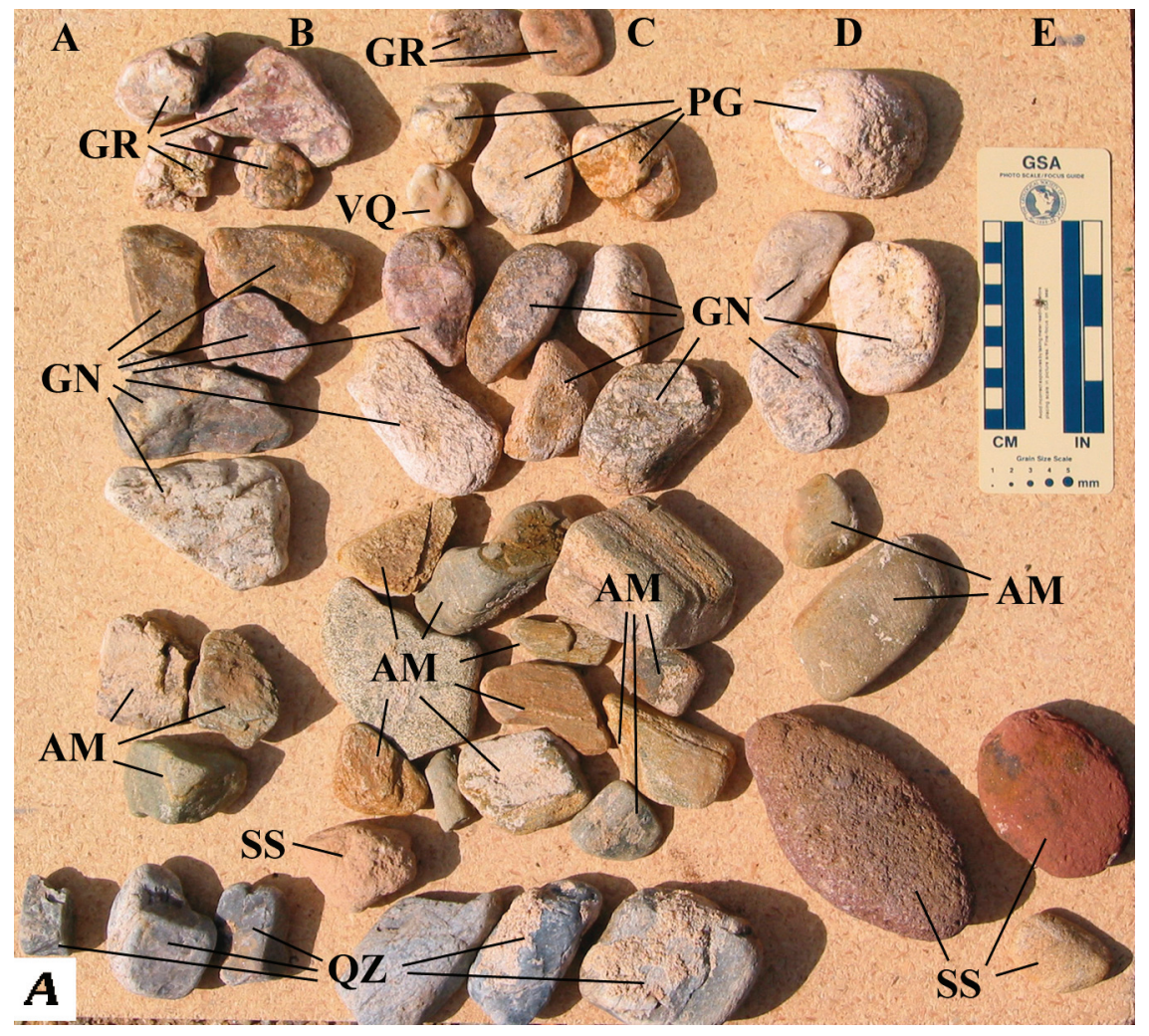

Figure A2. Poorly rounded gravel, mostly gneiss, amphibolite and quartzite, Verdos Alluvium, locality 44, Ralston Creek. Mostly first-cycle gravel derived from the mountain drainage basin of Ralston Creek; contains some recycled clasts of Rocky Flats Alluvium. Collection composed of about 50 pebbles drawn from a larger sample; roundness and lithologies are close to proportions counted in the whole sample. Pebbles arranged in columns of equal roundness ( $A$, angular; $B$, subangular; $C$, subround; $D$, rounded; $E$, well rounded) and rows of like lithology (GR, granite; GN, quartzo-feldspathic gneiss; PG, pegmatite; V0, vein quartz; AM, amphibolite (includes schist); SS, sandstone; 0Z, quartzite). Scale shows centimeters (left) and inches (right). 
Table A3. Lithology versus roundness of pebbles in Rocky Flats, Verdos, and Slocum Alluvium derived from Green Mountain.

[Pebble size: 1-3 in (2.5-7.6 cm). Based on samples of 100 pebbles each from three localities, one each in Rocky Flats, Verdos, and Slocum Alluvium. Roundness classes: A, angular; B, subangular; C, subrounded; D, rounded; E, well rounded (Pettijohn, 1975, fig. 3-24). OBS, observed frequency; EXP, expected frequency. $\mathrm{CHI}^{2}$, cell chi-square value. Totals, observed and expected frequencies for roundness (columns) and lithologies (rows). For the contingency table, chi square $=14.1$; significance $=0.168$. Lithologies having zero frequency for some roundness classes (amphibolite + schist + diabase and chert) omitted from table]

\begin{tabular}{|c|c|c|c|c|c|c|c|c|c|c|}
\hline \multirow[t]{2}{*}{ Lithology } & \multicolumn{3}{|c|}{ Roundness A+B } & \multicolumn{3}{|c|}{ Roundness C } & \multicolumn{3}{|c|}{ Roundness D+E } & \multirow[t]{2}{*}{ Totals } \\
\hline & OBS & EXP & $\mathrm{CHI}^{2}$ & OBS & EXP & $\mathrm{CHI}^{2}$ & OBS & EXP & $\mathrm{CHI}^{2}$ & \\
\hline Gneiss & 11 & 10.3 & 0.05 & 21 & 22.1 & 0.05 & 18 & 17.6 & 0.01 & 50 \\
\hline Granite $^{1}$ & 3 & 4.8 & 0.68 & 10 & 10.2 & 0.00 & 10 & 8.1 & 0.45 & 23 \\
\hline Pegmatite & 23 & 20.1 & 0.42 & 49 & 42.8 & 0.90 & 25 & 34.1 & 2.43 & 97 \\
\hline Vein Quartz & 7 & 8.7 & 0.33 & 19 & 18.5 & 0.01 & 16 & 14.8 & 0.10 & 42 \\
\hline Sandstone & 4 & 5.0 & 0.20 & 14 & 10.6 & 1.09 & 6 & 8.4 & 0.69 & 24 \\
\hline Volcanic rocks ${ }^{2}$ & 12 & 11.2 & 0.06 & 15 & 23.8 & 3.25 & 27 & 19.0 & 3.37 & 54 \\
\hline Totals & 60 & 60.1 & & 128 & 128 & & 102 & 102 & & 290 \\
\hline
\end{tabular}

${ }^{1}$ Includes igneous rocks of intermediate composition.

${ }^{2}$ Mostly porphyritic rocks; includes minor scoria and tuff.

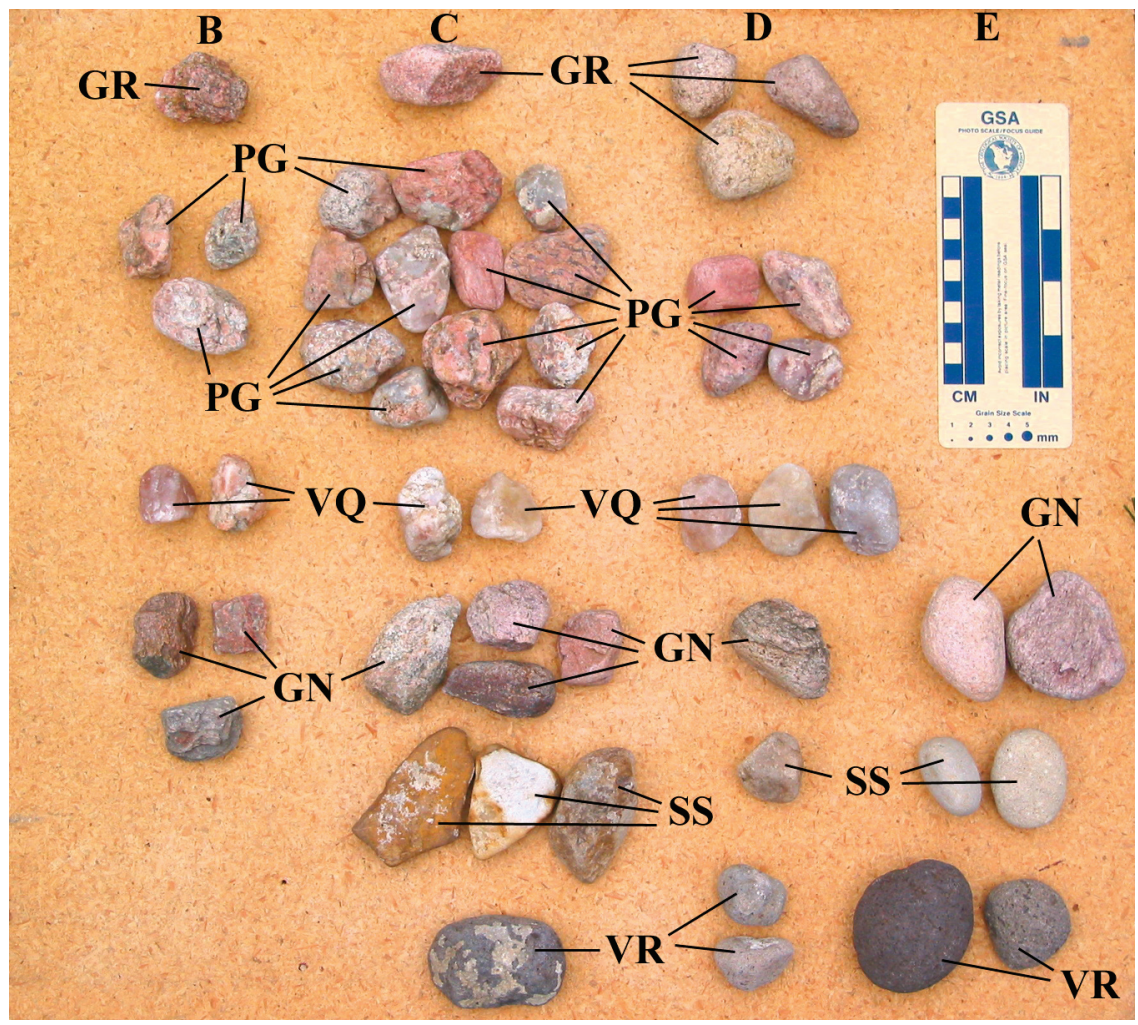

Figure A3. Moderately rounded gravel, pegmatite and gneiss, some vein quartz, and volcanic rock, Slocum Alluvium, locality 67, Bear Creek. Mostly recycled from Denver Formation of Green Mountain; contains some first-cycle sandstone from Cretaceous formations. Collection composed of about 50 pebbles drawn from a larger sample; roundness and lithologies are close to proportions counted in the whole sample. Pebbles arranged in columns of equal roundness ( $B$, subangular; $C$, subround; $D$, rounded; $E$, well rounded) and rows of like lithology (GR, granite; GN, quartzo-feldspathic gneiss; PG, pegmatite; VQ, vein quartz; SS, sandstone; VR, volcanic rock). Scale shows centimeters (left) and inches (right). 
Table A4. Lithology versus roundness of pebbles in Rocky Flats and Verdos Alluvium, divide between Big Dry Creek and South Platte River.

[Pebble size: 1-3 in (2.5-7.6 cm). Based on samples of 100 pebbles each from two localities (three samples) in Rocky Flats and two localities in Verdos Alluvium. Roundness classes: A, angular; B, subangular; C, subrounded; D, rounded; E, well rounded (Pettijohn, 1975, fig. 3-24). OBS, observed frequency; EXP, expected frequency. $\mathrm{CHI}^{2}$, cell chi-square value. Totals, observed and expected frequencies for roundness (columns) and lithologies (rows). For the contingency table, chi square $=46.8$; significance $=<0.0001$. Lithologies having zero frequency for some roundness classes (volcanic rocks, sandstone, and chert) omitted from table]

\begin{tabular}{|c|c|c|c|c|c|c|c|c|c|c|c|c|c|}
\hline \multirow[t]{2}{*}{ Lithology } & \multicolumn{3}{|c|}{ Roundness A+B } & \multicolumn{3}{|c|}{ Roundness C } & \multicolumn{3}{|c|}{ Roundness D } & \multicolumn{3}{|c|}{ Roundness E } & \multirow[t]{2}{*}{ Totals } \\
\hline & OBS & EXP & $\mathrm{CHI}^{2}$ & OBS & EXP & $\mathrm{CHI}^{2}$ & OBS & EXP & $\mathrm{CHI}^{2}$ & OBS & EXP & $\mathrm{CHI}^{2}$ & \\
\hline Gneiss & 11 & 8.9 & 0.50 & 30 & 25.2 & 0.91 & 25 & 33.5 & 2.16 & 13 & 11.3 & 0.26 & 79 \\
\hline Pegmatite & 21 & 15.4 & 2.04 & 41 & 43.5 & 0.14 & 58 & 57.7 & 0.00 & 16 & 19.5 & 0.63 & 136 \\
\hline Vein quartz +quartzite & 15 & 11.0 & 1.45 & 39 & 31.0 & 2.06 & 38 & 41.1 & 0.23 & 5 & 13.9 & 5.70 & 97 \\
\hline Mafic rocks ${ }^{2}$ & 3 & 6.2 & 1.65 & 22 & 17.6 & 1.10 & 23 & 23.3 & 0.00 & 7 & 7.9 & 0.10 & 55 \\
\hline
\end{tabular}

\footnotetext{
${ }^{1}$ Includes igneous rocks of intermediate composition.
}

${ }^{2}$ Amphibolite, biotite schist, and diabase.

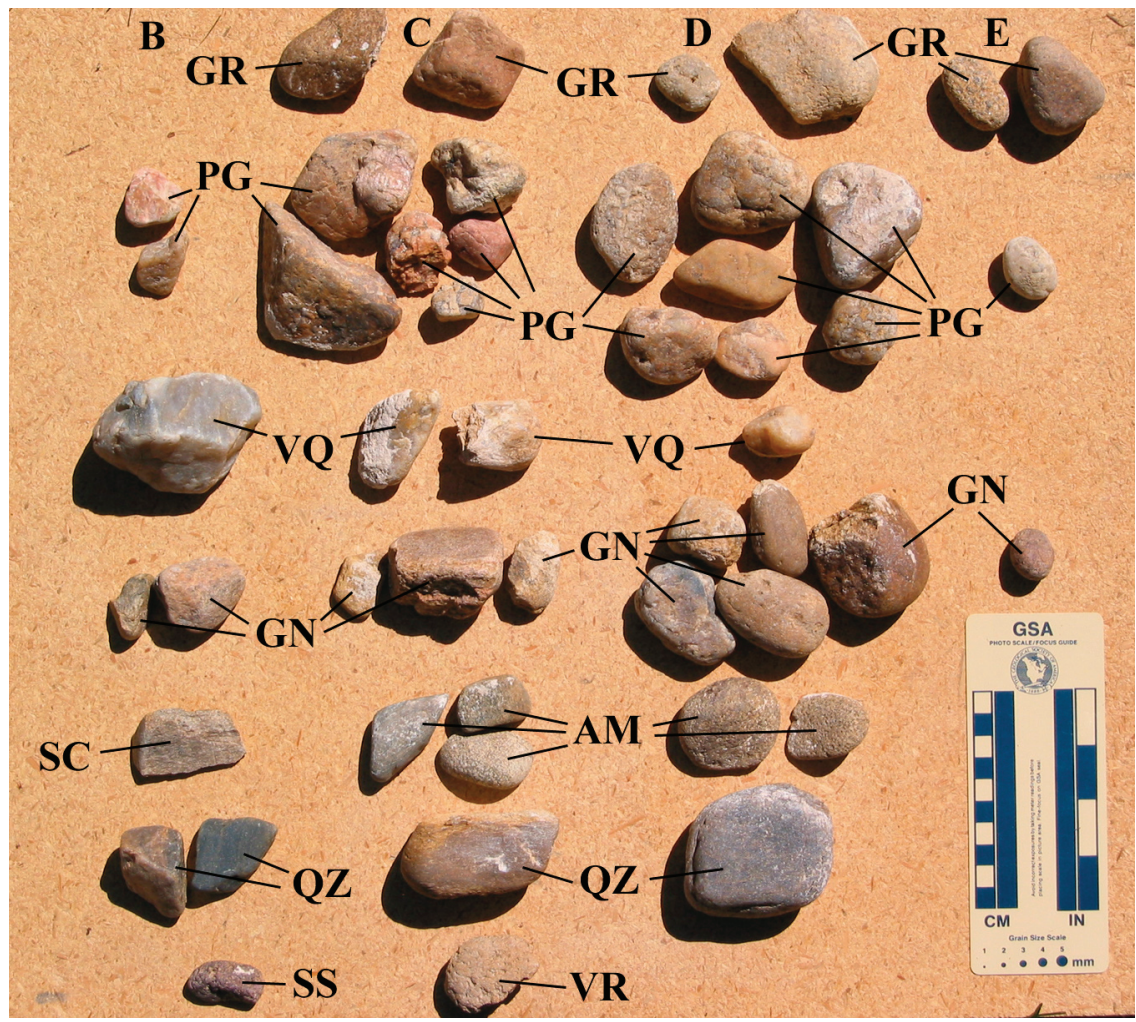

Figure A4. Moderately rounded gravel with granite, pegmatite, gneiss, vein quartz, amphibolite, and quartzite, Verdos Alluvium, locality 64, divide between South Platte River and Big Dry Creek. Mostly recycled from multiple sources, including Rocky Flats Alluvium on drainage divide. Collection composed of about 50 pebbles drawn from a larger sample; roundness and lithologies are close to proportions counted in the whole sample. Pebbles arranged in columns of equal roundness $(B$, subangular; $C$, subround; $D$, rounded; $E$, well rounded) and rows of like lithology (GR, granite; PG, pegmatite; VQ, vein quartz; GN, quartzo-feldspathic gneiss; AM, amphibolite; SC, schist; SS, sandstone; VR, volcanic rock; $\mathrm{OZ}$, quartzite). Scale shows centimeters (left) and inches (right). 
Table A5. Lithology versus roundness of pebbles in Louviers and Broadway Alluvium, Clear Creek.

[Pebble size: 1-3 in (2.5-7.6 cm). Based on samples of 100 pebbles each from five localities above the confluence of Clear Creek and Ralston Creek. Roundness classes: A, angular; B, subangular; C, subrounded; D, rounded; E, well rounded (Pettijohn, 1975, fig. 3-24). OBS, observed frequency; EXP, expected frequency. $\mathrm{CHI}^{2}$, cell chi-square value. Totals, observed and expected frequencies for roundness (columns) and lithologies (rows). For the contingency table, chi square $=67.3$; significance $=<0.0001$ Lithologies having zero frequency for some roundness classes (sandstone and chert) omitted from table]

\begin{tabular}{|c|c|c|c|c|c|c|c|c|c|c|c|c|c|}
\hline \multirow[t]{2}{*}{ Lithology } & \multicolumn{3}{|c|}{ Roundness A+B } & \multicolumn{3}{|c|}{ Roundness C } & \multicolumn{3}{|c|}{ Roundness D } & \multicolumn{3}{|c|}{ Roundness E } & \multirow[t]{2}{*}{ Totals } \\
\hline & OBS & EXP & $\mathrm{CHI}^{2}$ & OBS & EXP & $\mathrm{CHI}^{2}$ & OBS & EXP & $\mathrm{CHI}^{2}$ & OBS & EXP & $\mathrm{CHI}^{2}$ & \\
\hline Gneiss & 9 & 10.0 & 0.10 & 23 & 25.8 & 0.30 & 63 & 60.5 & 0.10 & 92 & 90.7 & 0.02 & 187 \\
\hline Granite $^{1}$ & 3 & 6.4 & 1.81 & 8 & 16.6 & 4.46 & 31 & 38.8 & 1.57 & 78 & 58.2 & 6.74 & 120 \\
\hline Pegmatite & 9 & 4.4 & 4.81 & 23 & 11.4 & 11.80 & 35 & 26.9 & 2.44 & 16 & 40.3 & 14.65 & 83 \\
\hline Vein quartz & 3 & 1.0 & 4.00 & 5 & 2.5 & 2.50 & 7 & 5.8 & 0.25 & 3 & 8.7 & 3.73 & 18 \\
\hline Mafic rocks ${ }^{2}$ & 2 & 3.9 & 0.93 & 7 & 10.2 & 1.00 & 18 & 23.9 & 1.46 & 47 & 35.9 & 3.43 & 74 \\
\hline
\end{tabular}

\footnotetext{
${ }^{1}$ Includes igneous rocks of intermediate composition.

${ }^{2}$ Amphibolitte, biotite schist, and diabase.

${ }^{3}$ Mostly porphyritic rocks; includes minor scoria and tuff.
}

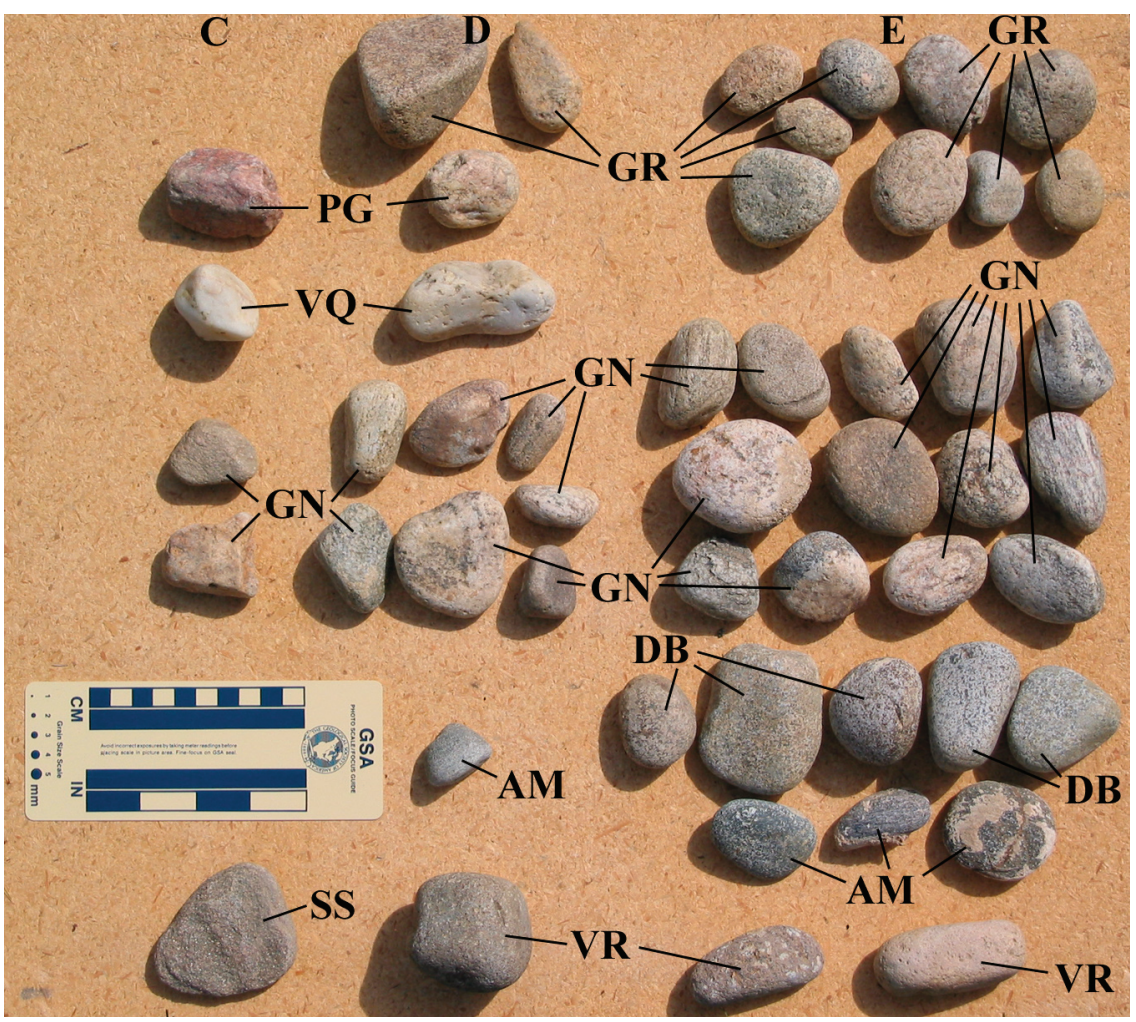

Figure A5. Well-rounded gravel, mostly granite and gneiss, Louviers Alluvium, locality 72, Clear Creek. Far-traveled, first-cycle outwash of Bull Lake ice retreat. Collection composed of about 50 pebbles drawn from a larger sample; roundness and lithologies are close to proportions counted in the whole sample. Pebbles arranged in columns of equal roundness ( $C$, subround; $D$, rounded; $E$, well rounded) and rows of like lithology (GR, granite; PG, pegmatite; V0, vein quartz; GN, quartzo-feldspathic gneiss; DB, diabase; AM, amphibolite; SS, sandstone; VR, volcanic rock). Scale shows centimeters (top) and inches (bottom). 
largest contributions to the total chi-square value are from pegmatite, with more moderate contributions from granite, vein quartz, and mafic rocks. For pegmatite, the observed frequency of well-rounded clasts (class E) is much less than expected, and the observed frequency of all classes below $\mathrm{E}$ is more than expected, indicating a tendency for pegmatite to retain angularity during transport. For granite, the observed frequency of class E exceeds the expected frequency, and the observed frequency of all other classes is less than expected, indicating a tendency for granite to continue to round more than other lithologies during transport. For vein quartz, observed in minor quantities, the observed frequency of wellrounded clasts is less than expected and that of less rounded (classes $\mathrm{A}+\mathrm{B}$ and $\mathrm{C}$ ) clasts are more than expected. Evidently, transport has not been sufficient to produce a highly rounded population of vein quartz. For mafic rocks, the observed frequency of well-rounded (class E) clasts exceeds expected frequency and observed frequency of classes $\mathrm{C}$ and $\mathrm{D}$ are less than expected. Mafic rocks tend to round more than expected during transport.

Well-rounded gravel of late Broadway(?) and Holocene Alluvium beneath the modern valley of the South Platte River valley north of Denver (table A6, fig. A6) shows quite different patterns in lithology versus roundness than the lithologically similar but much older gravel on the divide between Big Dry Creek and the South Platte River. An unknown but probably large proportion of South Platte gravel was first transported many tens of kilometers from its source during late Pleistocene time; some of this gravel has been recycled during Holocene time. In the South Platte gravel, pegmatite is less rounded by far than other lithologies, whereas gneiss and granite are more rounded. For pegmatite, observed frequencies of angular plus subangular (roundness classes $\mathrm{A}+\mathrm{B}$ ) and of subround clasts (class $\mathrm{C}$ ) is much more than expected; the observed frequency of well-rounded clasts (class E) is much less than expected. For gneiss and granite, observed frequencies of angular plus subangular (classes $\mathrm{A}+\mathrm{B}$ ) and of subround (class C) clasts is less than expected; observed frequency of well-rounded (class E) clasts is greater than expected. Unlike near-source and recycled gravels, and the Louviers gravel of Clear Creek, observed and expected frequencies for vein quartz + quartzite are nearly equal.

Like the gravel of the South Platte River, much of the well-rounded gravel in the modern valley of the Cache la Poudre River valley (table A7) was first transported long distances during late Pleistocene time; some has been reworked since. Pegmatite is less rounded than other lithologies, whereas gneiss, granite, and quartzite tend to be more well-rounded. For pegmatite, the observed frequency of angular plus subangular (roundness classes $\mathrm{A}+\mathrm{B}$ ) and subround (class $\mathrm{C}$ ) clasts is much greater than expected, and the observed frequency of well-rounded (class E) clasts is less than expected (table A7). Opposite relations are seen for granite (class $\mathrm{C}$, observed is less than expected; class E, observed is more than expected).
For gneiss, the observed frequency of classes $A+B$ is less than expected and of class $\mathrm{E}$, more than expected. For quartzite, the observed frequency of classes $\mathrm{A}+\mathrm{B}$ is less than expected and that of class $E$ is greater than expected. Differences for vein quartz are smaller but similar to those for quartzite. Even more than South Platte gravel, both quartzite and vein quartz show the results of prolonged abrasion and transport. For sandstone, only the observed frequency of classes $\mathrm{A}+\mathrm{B}$ differs (is greater than) from the expected frequency. Frequencies for mafic rocks and volcanic rocks are close to expected values, suggesting that these lithologies are not far-traveled, but perhaps derived from adjacent old gravel.

\section{Results}

The results of this investigation into the correlation between lithology and roundness show some genetic relationships (table A8). The most consistent relationship is the tendency of pegmatite to be under-represented among rounded and well-rounded clasts, and over-represented among angular and subangular clasts. The behavior of pegmatite is similar in all cases except one. Evidently, rounding of pegmatite is retarded by a tendency to fracture into new, angular clasts. We suggest that production of angular clasts is most likely the result of breakage along large crystal boundaries. In contrast, granite, including nonfoliated igneous rocks of intermediate composition, tends to be over-represented among rounded and well-rounded clasts and under-represented among angular and subangular clasts. The behavior of granite is consistent in all cases except one for which data are available; all of these cases represent clast populations that contain considerable recycled material or have been transported long distances by large streams having glaciated headwater valleys. To a lesser degree, quartzo-feldspathic gneiss shows a trend similar to granite. As a working hypothesis, when analysis of contingency tables shows a preference for angular clasts by pegmatite and of well-rounded clasts for granite and gneiss in the same deposit, transport for long distances in a stream having glaciated headwater valleys seems likely.

Vein quartz and quartzite (combined or separately) show a contrasting trend to that of pegmatite, granite, and gneiss. Except for some far-traveled clast populations, these resistant lithologies tend to be under-represented among rounded and well-rounded clasts and over-represented among angular and subangular clasts. This preference for angular and subangular clasts is undoubtedly a reflection of the hardness of quartz and its resistance to abrasion. In some clast populations, frequencies of vein quartz and quartzite do not depart from expected frequencies. Only in gravel beneath the modern valley of the Cache la Poudre River does vein quartz and quartzite show a preference for rounded and well-rounded classes, signifying that the gravel of this river has the most mature composition of those studied. 
Table A6. Lithology versus roundness of pebbles in latest Pleistocene Broadway(?) and Holocene Alluvium, South Platte River north of Denver (Lindsey and others, 1998b).

[Pebble size: $0.75-1.5$ in $(1.9-3.8 \mathrm{~cm})$. Based on 10 samples of 50 pebbles each drawn from three gravel pits, Holocene and Broadway(?) Alluvium. Roundness classes: A, angular; B, subangular; C, subrounded; D, rounded; E, well rounded (Pettijohn, 1975, fig. 3-24). OBS, observed frequency; EXP, expected frequency. $\mathrm{CHI}^{2}$, cell chi-square value. Totals, observed and expected frequencies for roundness (columns) and lithologies (rows). For the contingency table, chi square $=96.6$; significance $=<.0001$. Lithologies having zero frequency for some roundness classes (amphibolite + schist + diabase, called "mafic rocks" in Lindsey and others, 1998b), volcanic rocks, sandstone, and chert omitted from table]

\begin{tabular}{|c|c|c|c|c|c|c|c|c|c|c|c|c|c|}
\hline \multirow[t]{2}{*}{ Lithology } & \multicolumn{3}{|c|}{ Roundness A+B } & \multicolumn{3}{|c|}{ Roundness C } & \multicolumn{3}{|c|}{ Roundness D } & \multicolumn{3}{|c|}{ Roundness E } & \multirow[t]{2}{*}{ Totals } \\
\hline & OBS & EXP & $\mathrm{CHI}^{2}$ & OBS & EXP & $\mathrm{CHI}^{2}$ & OBS & EXP & $\mathrm{CHI}^{2}$ & OBS & EXP & $\mathrm{CHI}^{2}$ & \\
\hline Gneiss & 5 & 14.3 & 6.07 & 21 & 29.6 & 2.51 & 46 & 40.0 & 0.90 & 47 & 35.1 & 4.07 & 119 \\
\hline Granite $^{1}$ & 6 & 14.9 & 5.33 & 14 & 30.9 & 9.22 & 44 & 41.7 & 0.13 & 60 & 36.5 & 15.08 & 124 \\
\hline Pegmatite & 43 & 24.1 & 14.90 & 77 & 49.8 & 14.87 & 55 & 67.2 & 2.22 & 25 & 58.9 & 19.53 & 200 \\
\hline Vein quartz + quartzite & 4 & 4.7 & 0.10 & 8 & 9.7 & 0.30 & 17 & 13.1 & 1.16 & 10 & 11.5 & 0.19 & 39 \\
\hline Totals & 58 & 58.0 & & 120 & 120.0 & & 162 & 162.0 & & 142 & 142.0 & & 482 \\
\hline
\end{tabular}

\footnotetext{
${ }^{1}$ Includes igneous rocks of intermediate composition.
}

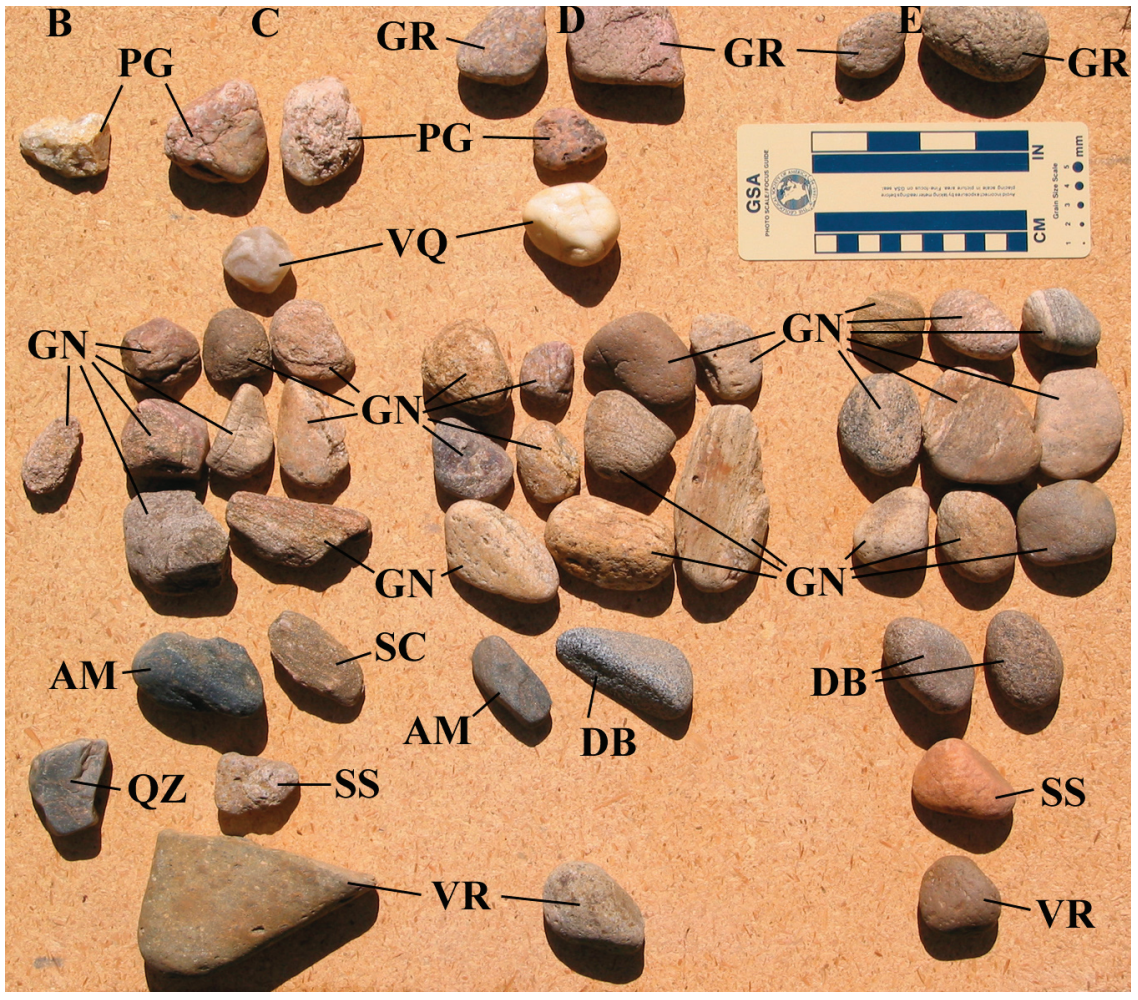

Figure A6. Well-rounded gravel, mostly gneiss, Holocene Alluvium (upper gravel unit), South Platte River. Mostly recycled from Broadway Alluvium of glacial outwash origin. Collection composed of about 50 pebbles drawn from a larger sample; roundness and lithologies are close to proportions counted in the whole sample. Pebbles arranged in columns of equal roundness ( $B$, subangular; $C$, subround; $D$, rounded; $E$, well rounded) and rows of like lithology (GR, granite; GN, quartzo-feldspathic gneiss; PG, pegmatite; V0, vein quartz; DB, diabase; AM, amphibolite; SC, schist; SS, sandstone; QZ, quartzite; VR, volcanic rock). Scale shows centimeters (bottom) and inches (top). 
Table A7. Lithology versus roundness of pebbles in latest Pleistocene Broadway(?) and Holocene Alluvium, Cache la Poudre River (Langer and Lindsey, 1999).

[Pebble size: 0.75-1.5 in (1.9-3.8 cm). Based on 29 samples of 50 pebbles each drawn from eight gravel pits, Holocene and Broadway(?) Alluvium. Roundness classes: A, angular; B, subangular; C, subrounded; D, rounded; E, well rounded (Pettijohn, 1975, fig. 3-24). OBS, observed frequency; EXP, expected frequency $\mathrm{CHI}^{2}$, cell chi-square value. Totals, observed and expected frequencies for roundness (columns) and lithologies (rows). For the contingency table, chi square $=$ 90.0; significance $=<.0001$. Volcanic rocks called "porphyry" in Langer and Lindsey, 1999]]

\begin{tabular}{|c|c|c|c|c|c|c|c|c|c|c|c|c|c|}
\hline \multirow[t]{2}{*}{ Lithology } & \multicolumn{3}{|c|}{ Roundness $A+B$} & \multicolumn{3}{|c|}{ Roundness C } & \multicolumn{3}{|c|}{ Roundness D } & \multicolumn{3}{|c|}{ Roundness E } & \multirow[t]{2}{*}{ Totals } \\
\hline & OBS & EXP & $\mathrm{CHI}^{2}$ & OBS & EXP & $\mathrm{CHI}^{2}$ & OBS & EXP & $\mathrm{CHI}^{2}$ & OBS & EXP & $\mathrm{CHI}^{2}$ & \\
\hline Gneiss & 3 & 12.3 & 7.02 & 13 & 15.9 & 0.53 & 33 & 30.1 & 0.28 & 54 & 44.7 & 1.94 & 103 \\
\hline Pegmatite & 104 & 83.6 & 5.02 & 144 & 108.1 & 11.89 & 213 & 204.7 & 0.34 & 239 & 303.7 & 13.77 & 700 \\
\hline Vein quartz & 4 & 8.5 & 2.36 & 8 & 11.0 & 0.80 & 22 & 20.8 & 0.07 & 37 & 30.8 & 1.25 & 71 \\
\hline Mafic rocks ${ }^{2}$ & 6 & 6.4 & 0.03 & 9 & 8.3 & 0.05 & 12 & 15.8 & 0.91 & 27 & 23.4 & 0.55 & 54 \\
\hline Volcanic rocks ${ }^{3}$ & 2 & 3.1 & 0.39 & 3 & 4.0 & 0.26 & 11 & 7.6 & 1.52 & 10 & 11.3 & 0.15 & 26 \\
\hline Totals & 173 & 173.0 & & 224 & 224.0 & & 424 & 424.0 & & 629 & 629.0 & & 1450 \\
\hline
\end{tabular}

\footnotetext{
${ }^{1}$ Includes igneous rocks of intermediate composition.

${ }^{2}$ Amphibolite, biotite schist, and diabase.

${ }^{3}$ Mostly porphyritic rocks; includes minor scoria and tuff.
}

Table A8. Summary of correlation of rounding with lithology, as predicted by chi-square tests of individual roundness classes for seven populations of clasts.

[Source tables: A1, Rocky Flats and upper Big Dry Creek; A2, Ralston Creek; A3, Green Mountain; A4, divide between Big Dry Creek and South Platte River; A5, Clear Creek; A6, South Platte River; A7, Cache la Poudre River. Correlation of alluvial units: Qh, Holocene Alluvium; Qb, Broadway Alluvium; Qlo, Louviers Alluvium; Qs, Slocum Alluvium; Qv, Verdos Alluvium; Qrf, Rocky Flats Alluvium. +, positive correlation: classes D and (or) E exceed expected frequency, classes A and (or) B less than expected; -, negative correlation: classes D and (or) E less than expected, classes A and (or) B exceed expected frequency; 0, no correlation: observed frequency approximately equals expected frequency for all classes; $0+$ or 0 -, slight positive or negative correlation (observed frequency slightly above or below expected frequency for one or more rounded or angular classes, respectively); ND, no data, frequency too small to determine correlation]

\begin{tabular}{l|cccccccc}
\hline & \multicolumn{3}{c|}{$\begin{array}{c}\text { Small streams- } \\
\text { unglaciated headwaters }\end{array}$} & \multicolumn{2}{c}{$\begin{array}{c}\text { Large streams- } \\
\text { glaciated headwaters }\end{array}$} \\
\cline { 2 - 7 } & \multicolumn{2}{|c|}{ Near-source } & \multicolumn{2}{c}{ Recycled } & \multicolumn{3}{c}{ Distant transport } \\
\hline Reference table & A1 & A2 & A3 & A4 & A5 & A6 & A7 \\
Alluvial units & Qv & Qp & Qs & Qv & Qb & Qh & Qh \\
& Qrf & Qv & Qv & Qrf & Qlo & Qb? & Qb? \\
& & & Qrf & & & & \\
\hline
\end{tabular}

\begin{tabular}{lccccccc}
\hline \multicolumn{7}{c}{ Correlation between rounding and lithology } \\
\hline Gneiss & + & 0 & 0 & 0 & 0 & + & + \\
Granite $^{1}$ & ND & ND & 0 & + & + & + & + \\
Pegmatite & 0 & - & - & - & - & - & - \\
Vein quartz and (or) quartzite & - & $0-$ & 0 & - & - & 0 & + \\
Mafic rocks $^{2}$ & ND & $0+$ & ND & 0 & + & ND & 0 \\
Sandstone $^{\text {Volcanic rocks }}{ }^{3}$ & ND & $0+$ & 0 & ND & ND & ND & $0-$ \\
& ND & ND & + & ND & 0 & ND & 0 \\
\hline
\end{tabular}

${ }^{1}$ Includes igneous rocks of intermediate composition.

${ }^{2}$ Amphibolite, biotite schist, and diabase.

${ }^{3}$ Mostly porphyritic rocks; includes minor scoria and tuff. 